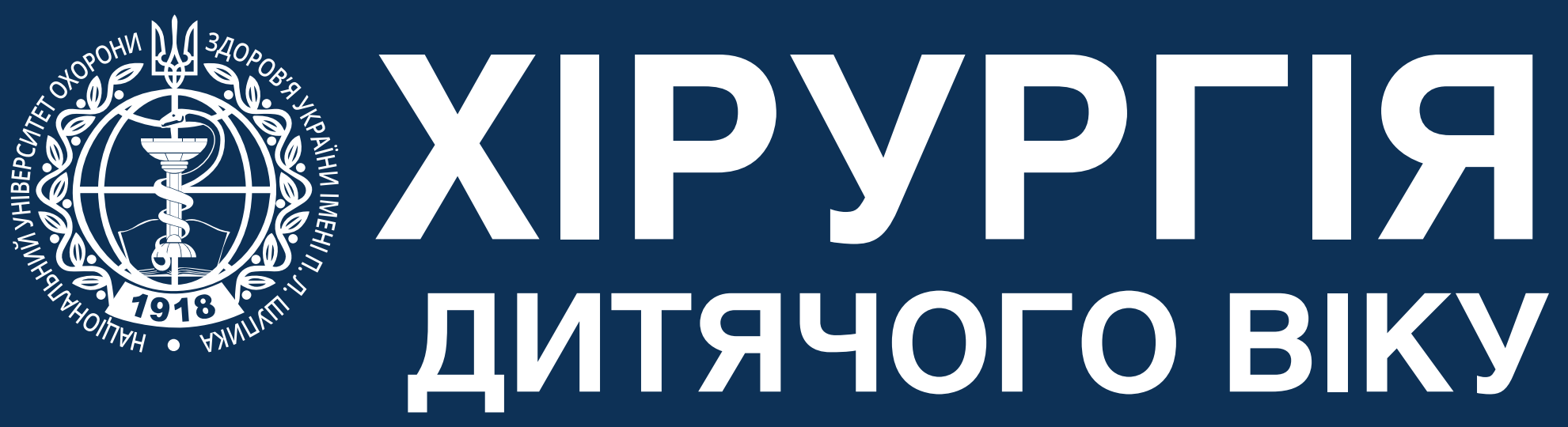

\title{
PAEDIATRIC SURGERY. UKRAINE 2021
}

Передплатний індекс 60162

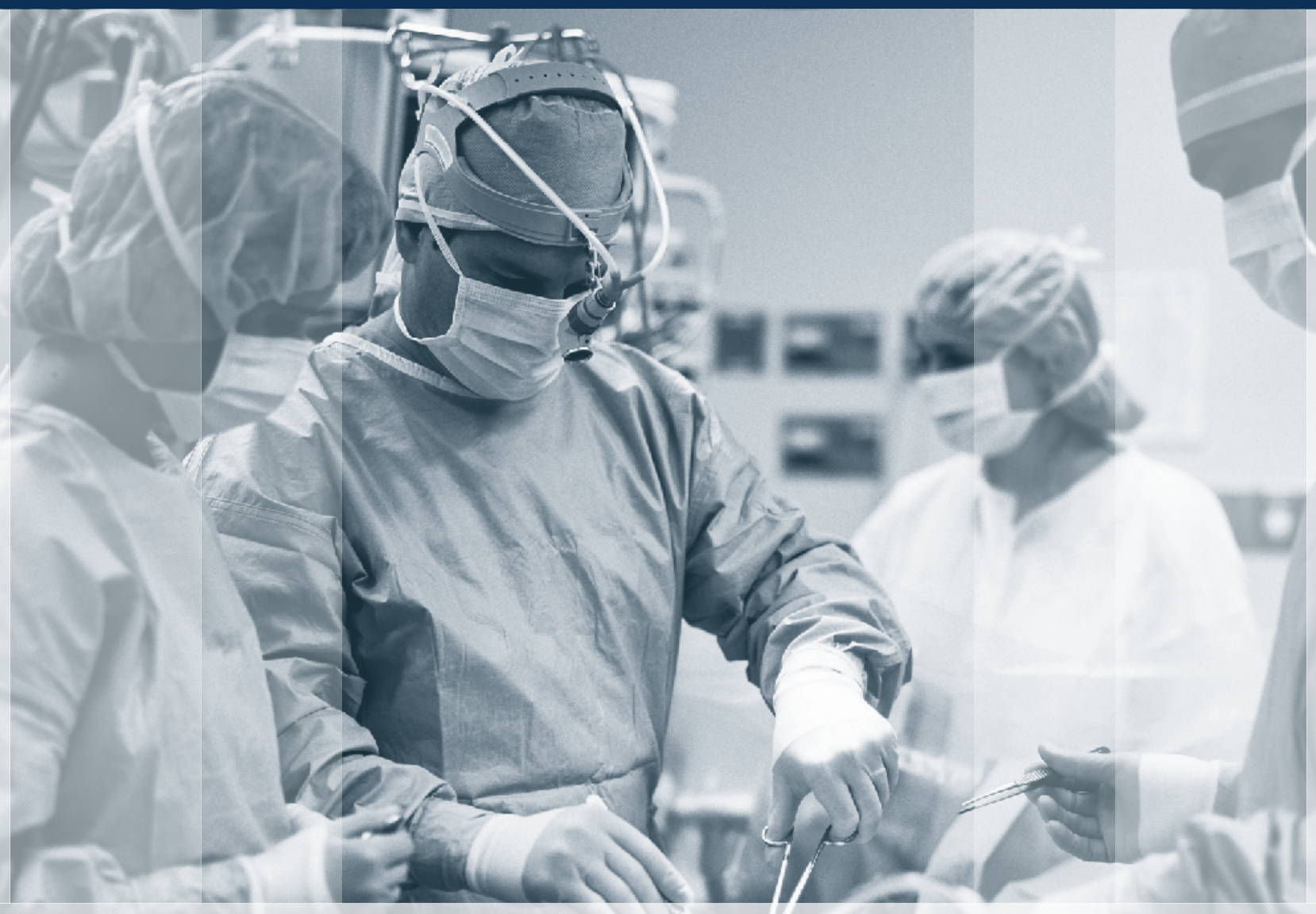

Торокальна хірургія

Абомінальна хірургія

Урологія та гінекологія

Ортопедія

Огляди

Клінічний випадок стор. 10

стор. 15

стор. 36

стор. 69

стор. 76

стор. 84
Клінічні рекомендації АCG: діагностика та лікування вогнищевих уражень печінки стор. 89 Матеріал відібраний для застосування в практичній діяльності дитячих хірургів

До уваги авторів Алгоритм реєстраціїіндексу Bченого ORCID 


\section{WORLD THROMBOSIS DAY}

13OCTOBER

\section{\#Ukraine_support WTD 2022}

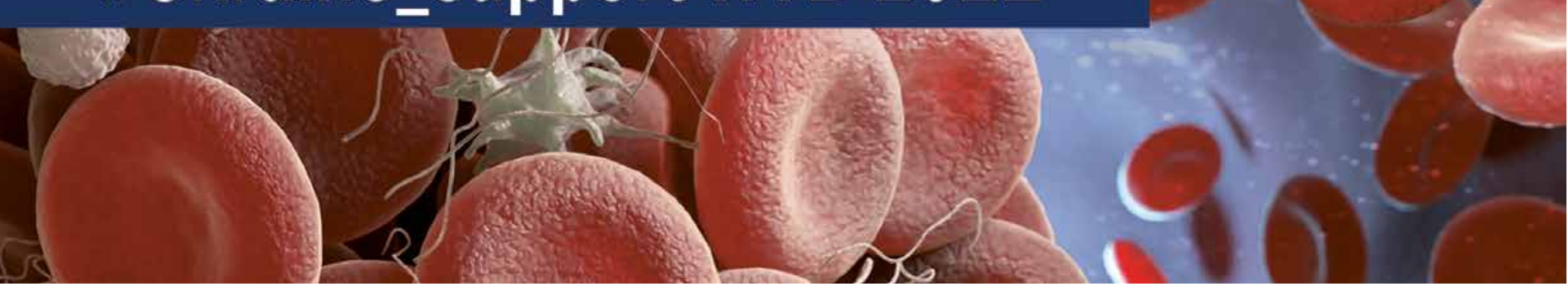

\section{Шановний колего!}

Ми прагнемо підвищити обізнаність про тромбоз, включаючи його причини, фактори ризику, симптоми та доказову профілактику і лікування. Зрештою, ми прагнемо зменшити смертність та інвалідність, спричинену цим станом.

Наша місія підтримує глобальну ціль Всесвітньої Асамблеї охорони здоров'я щодо скорочення передчасної смертності від неінфекційних захворювань на 25 відсотків до 2025 року.

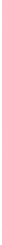

Долучайтесь! Збережемо здоров'я нації! Обізнаний сьогодні - врятований завтра!

Разом ми сила!

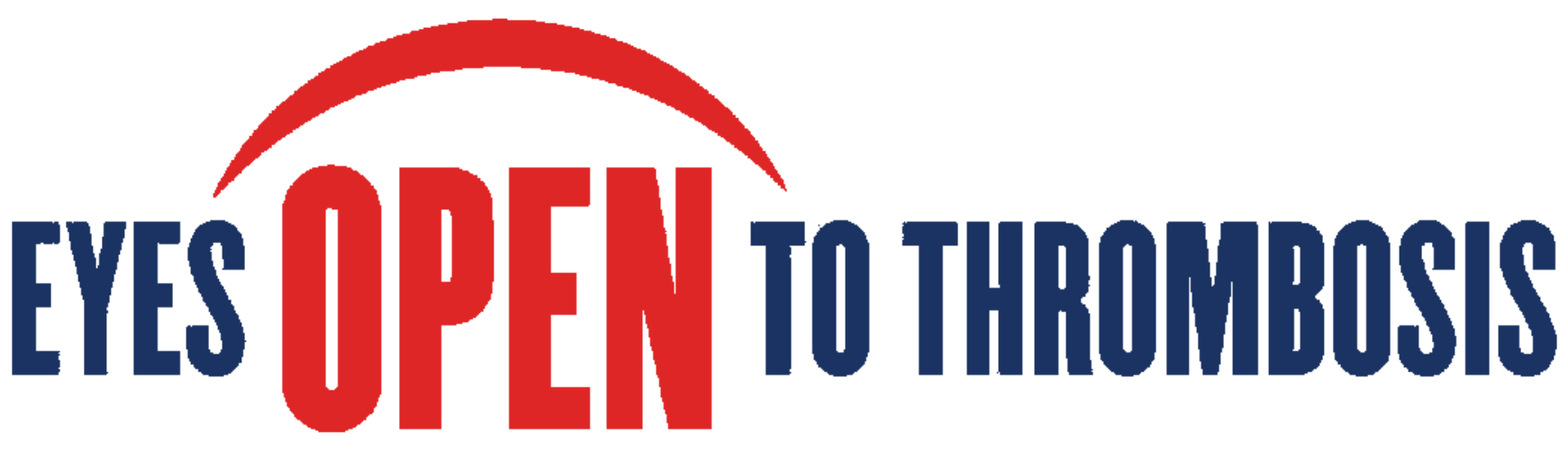

wtd-ukraine.org 


\section{НАЦІОНАЛЬНИЙ УНІВЕРСИТЕТ ОХОРОНИ ЗДОРОВ'Я УКРАЇНИ ІМЕНІ П.Л. ШУПИКА ВСЕУКРАЇНСЬКА АСОЦІАЦІЯ ДИТЯЧИХ ХІРУРГІВ ТОВ «ГРУПА КОМПАНІЙ «МЕД ЕКСПЕРТ» ХІРУРГІЯ ДИТЯЧОГО ВІКУ}

науково-практичний спеціалізований журнал

\section{ХИРУРГИЯ ДЕТСКОГО ВОЗРАСТА}

научно-практический специализированный журнал

\section{ГОЛОВНИЙ РЕДАКТОР}

Котенко О.Г., доктор мед. наук, професор, керівник Центру хірургії печінки та підшлункової залози (Київ, Україна)

\section{ШЕФ-РЕДАКТОР}

Толстанов О.К., доктор мед. наук, професор, проректор з навчальнопедагогічної роботи НУОЗ України імені П.Л. Шупика (Київ, Україна) Русак П.С., доктор мед. наук, професор кафедри дитячої хірургії НУОЗ України імені П.Л. Шупика, завідувач хірургічним відділенням №1 Житомирської обласної дитячої клінічної лікарні (Житомир, Україна)

\section{РЕДАКЦІЙНА КОЛЕГІЯ}

Аверін B.I. (Мінськ, Білорусь) АльДжахдалі А. (Альхобар, Саудівська Аравія) Бабуч C.I. (Кишинів, Молдова) Бензар I.М. (Київ, Україна) Боднар О.Б. (Чернівці, Україна) Вдовиченко Ю.П. (Київ, Україна) Веселий С.В. (Лиман, Україна) Вороненко Ю.В. (Київ, Україна) Горбатюк О.М. (Київ, Україна) Гудумак Є.М. (Кишинів, Молдова) Данилов О.А. (Київ, Україна) Дігтяр В.А. (Дніпро, Україна) Дубровін О.Г. (Київ, Україна) Ємець I.М. (Київ, Україна) Запорожан С.Й. (Тернопіль, Україна) Йокіч Р. (Новий Сад, Сербія) Калічинський П. (Варшава, Польща) Капуллер В. (Єрусалим, Ізраїль) Ковальчук В.І. (Гродно, Білорусь) Козинець Г.П. (Київ, Україна) Конопліцький В.С. (Вінниця, Україна)

Косаковський А.Л. (Київ, Україна) Кривченя Д.Ю. (Київ, Україна) Ксьонз І.В. (Полтава, Україна) Левицький А.Ф. (Київ, Україна) Ліма М. (Болонья, Італія)
Лопез М. (Барселона, Іспанія) Лосев О.О. (Одеса, Україна) Мюнтер Х. (Лондон, Великобританія)

Наконечний А.Й. (Львів, Україна)

Патковський Д. (Вроцлав, Польща) Переяслов А.А. (Львів, Україна) Петербургський В.Ф. (Київ, Україна)

Петерсонс А. (Рига, Латвія) Погорілий В.В. (Вінниця, Україна) Притула В.П. (Київ, Україна) Ротенберг С. (Денвер, США) Руденко Н.М. (Київ, Україна) Слєпов О.К. (Київ, Україна) Спахі O.В. (Запоріжжя, Україна)

Текгюл С. (Анкара, Туреччина) Усенко О.Ю. (Київ, Україна) Фархат В. (Торонто, Канада) Фофанов О.Д. (Івано-Франківськ, Україна)

Храпач В.В. (Київ, Україна) Чаудерна П. (Гданськ, Польща) Ченг В. (Пекін, Китай)

Черіан А. (Лондон, Великобританія) Юркевич Б. (Варшава, Польща)

\section{НАУКОВІ КОНСУЛЬТАНТИ}

Боднар Б.М. (Чернівці, Україна) Давиденко В.Б. (Харків, Україна) Кукуруза Ю.П. (Вінниця, Україна) Лазоришенець В.В. (Київ, Україна)
Макаров А.В. (Київ, Україна) Момотов A.O. (Київ, Україна) Ніколаєва Н.Г. (Одеса, Україна) Сушко В.I. (Дніпро, Україна)

НАУКОВИЙ РЕДАКТОР Верголяс М.Р. (Київ, Україна)

\section{CEKPETAPIAT}

Горєлік В.В. (Київ, Україна)

Доманський О.Б. (Київ, Україна)

Мельниченко М.Г. (Одеса, Україна)

Пономаренко О.П. (Київ, Україна)
Рибальченко В.Ф. (Київ, Україна)

Талько М.O. (Київ, Україна)

Чаварга М.І. (Ужгород, Україна)

Чеканов Д.Ю. (Миколаїв, Україна)
Видавець ТОВ «Група компаній «Мед Експерт»

Свідоцтво про державну реєстрацію 3МІ КВ № 22500-12400ПР від 13.01.2017 р.

Видається з 2003 р.

Періодичність виходу - 4 рази на рік

Наказом МОН України №612 від 07.05.2019 р. журнал «Хірургія дитячого віку» включено до Переліку наукових фахових видань України, категорія Б, в яких можуть публікуватися результати дисертаційних робіт на здобуття наукових фахових ступенів доктора і кандидата наук

Затверджено Вченою радою Національного університету охорони здоров'я України імені П.Л. Шупика. Протокол №7 від 08.09.2021 p. Підписано до друку 27.09.2021 p.

Журнал «Хірургія дитячого віку» реферується Інститутом проблем реєстрації інформації НАН України

Адреса для листування:

ТОВ «Група компаній Мед Експерт»,

«Хірургія дитячого віку», а/с 80, м. Київ-211, Україна, 04211

Тел./факс: +38 044 498-08-80

E-mail: pediatric.surgery.ukraine@gmail.com; pediatr@med-expert.com.ua http://med-expert.com.ua/

Формат 60х90/8. Папір офсетний

Ум. друк. арк. 16. Обл.-вид. арк. 13,95.

Загальний наклад 1000 прим.

Зам. 28.09/01 від 28.09.2021 p.

Надруковано з готових фотоформ у типографії «Аврора-принт»,

м. Київ, вул. Причальна, 5, тел. +38 (044) 550-52-44 Свідоцтво суб'єкта видавничої справи:

А00 № 777897 від 06.07.2009 p.

Всі статті рецензовані. Повний або частковий передрук або тиражування у будь-який спосіб матеріалів, опублікованих у цьому виданні, допускається лише за письмовим дозволом редакції. Відповідальність за зміст рекламних матеріалів несе рекламодавець.

Журнал «Хірургія дитячого віку» включений у наукометричні, реферативні та пошукові бази даних: DOAJ, WorldCat, SIS, EuroPub, BASE, Sherpa Romeo, Index Copernicus International, Google Scholar, CrossRef, Джерело. Статтям журналу присвоюється DOI.

Увага! Здійснити передплату видання «Хірургія дитячого віку» можна у будь-якому поштовому відділенні України

Передплатний індекс 60162

(с) Національний університет охорони здоров’я України імені П.Л. Шупика, 2021

() Всеукраїнська асоціація дитячих хірургів, 2021 (c) ТОВ «Група компаній «Мед Експерт», 2021

Київ 2021 


\title{
SHUPYK NATIONAL HEALTHCARE UNIVERSITY OF UKRAINE
}

UKRAINIAN ASSOCIATION PAEDIATRICS SURGERY

GROUP OF COMPANIES MED EXPERT, LLC

PAEDIATRIC SURGERY. UKRAINE

\author{
Scientific and Practical Journal
}

\section{EDITOR-IN-CHIEF}

Kotenko O.G., Doctor of Medical Sciences, Professor, Shief of Hepatopancreatic Surgery Centr (Kyiv, Ukraine)

\section{CHIEF EDITOR}

Tolstanov O.K., Doctor of Medical Sciences, Professor, First Deputy Rector, of the Shupyk National Healthcare University of Ukraine (Kyiv, Ukraine) Rusak P.S., Doctor of Medical Sciences, Professor of Pediatric Surgery Department Shupyk National Healthcare University of Ukraine; Head of Department pediatric surgery of Zhytomyr Regional Children's Clinical Hospital (Zhytomyr, Ukraine)

\section{EDITORIAL BOARD}

Averin V.I. (Minsk, Belarus)

AlJahdali A. (Alkhobar, Saudi Arabia)

Babuci S. (Kishinev, Moldova)

Benzar I.M. (Kyiv, Ukraine)

Bodnar O.B. (Chernivtsi, Ukraine)

Vdovichenko Yu.P. (Kyiv, Ukraine)

Veseliy S.V. (Liman, Ukraine)

Voronenko Yu.V. (Kyiv, Ukraine)

Gorbatyuk O.M. (Kyiv, Ukraine)

Gudumak E.M. (Chisinau, Moldova)

Danylov O.A. (Kyiv, Ukraine)

Digtyar V.A. (Dnipro, Ukraine)

Dubrovyn O.G. (Kyiv, Ukraine)

Emetc I.M. (Kyiv, Ukraine)

Zaporozhan S.Y. (Ternopil, Ukraine)

Jokic R. (Novi Sad, Serbia)

Kaliciński P. (Warsaw, Poland)

Kapuller V. (Jerusalem, Israel)

Kovalchuk B.I. (Grodno, Belarus)

Kozinetc G.P. (Kyiv, Ukraine)

Konoplitskiy B.S. (Vinnytsia, Ukraine)

Kosakovs'kiy A.L. (Kyiv, Ukraine)

Krivchenya D.Yu. (Kyiv, Ukraine)

Ksyonz I.V. (Poltava, Ukraine)

Kutcenok Ya.B. (Kyiv, Ukraine)

Levitckiy A.F. (Kyiv, Ukraine)

\section{SCIENTIFIC ADVISERS}

Bodnar B.M. (Chernyvtcy, Ukraine)

Davidenko V.B. (Kharkiv, Ukraine)

Kukuruza Yu.P. (Vinnitca, Ukraine)

Lazorishenetc V.V. (Kyiv, Ukraine)

SCIENTIFIC EDITOR Vergolyas M.R. (Kyiv, Ukraine)

\section{SECRETARIAT}

Gorelyk V.V. (Kyiv, Ukraine)

Domanskiy O.B. (Kyiv, Ukraine)

Melnichenko M.G. (Odesa, Ukraine)

Ponomarenko O.P. (Kyiv, Ukraine)
Lima M. (Bologna, Italy)

Lopez M. (Barcelona, Spain)

Losev O.O. (Odesa, Ukraine)

Munther H. (London, Great Britain)

Nakonechnyi A.Y. (Lviv, Ukraine)

Patkowski D. (Wroclaw, Poland)

Pereyaslov A.A. (Lviv, Ukraine)

Peterburgskiy V.F. (Kyiv, Ukraine)

Petersons A. (Riga, Latvia)

Pogoriliy V.V. (Vinnytsia, Ukraine)

Pritula V.P. (Kyiv, Ukraine)

Rothenberg S. (Denver, USA)

Rudenko N.M. (Kyiv, Ukraine)

Sliepov O.K. (Kyiv, Ukraine)

Spahy O.V. (Zaporizhzhia, Ukraine)

Tekgul S. (Ankara, Turkey)

Usenko O.Yu. (Kyiv, Ukraine)

Farhat W. (Toronto, Canada)

Fofanov O.D. (Ivano-Frankivsk, Ukraine)

Hrapach V.V. (Kyiv, Ukraine)

Czauderna P. (Gdansk, Poland)

Cheng W. (Beijing, China)

Cherian A. (London, Great Britain)

Jurkiewicz B. (Warsaw, Poland)

Makarov A.V. (Kyiv, Ukraine)

Momotov A.O. (Kyiv, Ukraine)

Nikolaeva N.G. (Odesa, Ukraine)

Sushko V.I. (Dnipro, Ukraine)
Rybalchenko V.F. (Kyiv, Ukraine)
Tal'ko M.O. (Kyiv, Ukraine)
Chavarga M.I. (Uzhgorod, Ukraine)
Chekanov D.Yu. (Mikolauiv, Ukraine)

Publisher - Group of companies MedExpert, LLC Certificate of registration of КВ No. 22500-12400ПР of 13.01.2017

Published since $2003 \mathrm{p}$.

Periodicity - 4 times a year

By the order of the Ministry of Education and Science of Ukraine No. 612 from May 7, 2019, the journal «Paediatric Surgery. Ukraine» was included in the List of specialized scientific editions of Ukraine in the field of medical sciences, category $\mathbf{B}$

Recommended by the Shupyk National Healthcare University of Ukraine, Protocol No.7

from 08.09.2021

Signed for publication 27.09.2021

The journal «Paediatric Surgery. Ukraine» abstracted by the Institute of Information Recording Problems of Ukraine

Mailing address:

Group of Companies Med Expert, LLC, «Paediatric Surgery. Ukraine», p/b 80, Kyiv, 04211, Ukraine, Tel./fax: +38 044 498-08-80

E-mail: pediatric.surgery.ukraine@gmail.com; pediatr@med-expert.com.ua; http://med-expert.com.ua

Format 60x90/8. Offset paper.

Conventional printed sheet. 13,95.

Total circulation is 1000 copies.

Ord. No. 28.09/01 from 28.09.2021

Printed in the «Aurora-print» printing house,

5, Prichalnaya Str., Kyiv, tel. (044) 550-52-44

Certificate A00 No. 777897 from 06.07.2009 y.

All articles reviewed. Total or partial copy of materials published in this publication at any way is available only by the letter of permission of the journal staff. Advertiser is responsible for the content of advertising materials.

Indexed and/or presented in: DOAJ, WorldCat, SIS, EuroPub, BASE, Sherpa Romeo, Index Copernicus International, Google Scholar, CrossRef, Djerelo.

Attention! Subscribe to the journal «Paediatric Surgery. Ukraine» you can at every post offices of Ukraine Subscription index $\mathbf{6 0 1 6 2}$

(C) Shupyk National Healthcare University of Ukraine, 2021

(C) Ukrainian Association Paediatric Surgery, 2021 (c) Group of Companies MedExpert, LLC, 2021 Kyiv 2021 


\section{3міст}

\section{ПОДї}

6 Толстанов О.К., Маменко М.Є., Русак П.С., Горелік В.В.

Перша міжнародна фахова школа для дитячих лікарів хірургічних спеціальностей

8 Перша відеоконференція дитячих урологів України з міжнародною участю «Odrex Pediatric Urology Meeting»

\section{ОРИГІНАЛЬНІ ДОСЛІДЖЕННЯ. ТОРАКАЛЬНА ХІРУРГІЯ}

10 Левицький А.Ф., Рогозинський В.О., Доляницький М.М., Дуда Л.В.

Гало-гравітаційна тракція при лікуванні складних $\left(>100^{\circ}\right)$ деформацій хребта у дітей із респіраторними дисфункціями

\section{ОРИГІНАЛЬНІ ДОСЛІДЖЕННЯ. АБДОМІНАЛЬНА ХІРУРГІЯ}

15 Скиба В.В., Рибальченко В.Ф., Іванько О.В., Борис Р.М., Дар Ясін Ахмед, Лисиия В.В.

Еволюція діагностики та хірургічного лікування інтраабдомінальних інфільтратів та абсцесів первинного та післяопераційного походження у хворих

30 Скиба В.В., Іванько О.В., Войтюк Н.В., Лисиия В.В., Косюк М.А., Корчемний I.O. Післяопераційна оцінка якості життя пацієнтів після лікування пахових гриж лапароскопічним та відкритим методами

\section{ОРИГІНАЛЬНІ ДОСЛІДЖЕННЯ УРОЛОГІЯ ТА ГІНЕКОЛОГІЯ}

36 Наконечний Р.А., Наконечний А. Цистоскопічні особливості вічок сечоводів у дітей з міхурово-сечовідним рефлюксом

43 Фофанов О.Д., Юриева А.П., Зіняк Б.М., Доценко Ю.Р., Фофанов В.О.

Перший досвід реконструктивно-пластичних операцій на сечовому міхурі у дітей

51 Пащенко К. Ю., Рой Н. В.

Етапна лапароскопічна тракційна орхіопексія за Shehata: перший досвід, технічні особливості, результати

56 Вешкуриева И.М., Аксельров М.А., Емельянова В.А., Супрунец, С.Н., Столяр А.В., Гордийчук С.Н., Лебедева К.А., Аиихмина Е.П., Баринов А.Л. Инфекции мочевых путей у новорожденных детей: микробный пейзаж и проблемы антибиотикорезистентности

\section{Content}

\section{EVENTS}

6 Tolstanov O.K., Mamenko M.E., Rusak P.S., Horelyk V.V.

The I International Professional School for Pediatric Surgical Specialties

8 The I Video Conference of Ukrainian Pediatric Urologists with international participation «Odrex Pediatric Urology Meeting»

\section{ORIGINAL ARTICLES. THORACIC SURGERY}

10 Levytskyi A.F., Rogozinskyi V.O., Dolianytskyi M.M., Duda L.V.

Halo-gravity traction in the treatment of complex spinal deformities in children with respiratory dysfunctions

\section{ORIGINAL ARTICLES. ABDOMINAL SURGERY}

15 Skyba V.V., Rybalchenko V.F., Ivanko A.V., Borys R.M., Dar Yasinya Akhmed, Lysytsa V.V.

Evolution of diagnosis and surgical treatment of intra-abdominal infiltrates, abscesses of primary and postoperative origin in patients

33 Skyba V.V., Ivanko A.V., Voytyuk N.V., Lysytsia V.V., Kosyk M.A., Korchemnyy I.O.

Postoperative condition of patients as a result of treatment of inguinal hernias by laparoscopic and open methods

\section{ORIGINAL ARTICLES. UROLOGY AND GYNECOLOGY}

36 Nakonechnyy R.A., Nakonechnyi A.Y. Cystoscopic features of the ureteral orifices in children with vesicoureteral reflux

43 Fofanov O.D., Jurtseva A.P., Zinyak B.M., Dotsenko Yu.R., Fofanov V.O.

An experience of reconstructive-plastic operations on the bladder in children

51 Pashchenko K.Yu., Roi N.V.

Staged laparoscopic traction orchiopexy by Shehata: first experience, technical features, results

56 Veshkurtseva I.M., Akselrov M.A., Emelyanova V.A., Suprunets S.N., Stolyar A.V., Gordiychuk S.N., Lebedeva K.A., Ashikhmina E.P., Barinov A.L. Urinary tract infections in newborn children: microbial landscape and antibiotic resistance problems 
63 Поцюрко А.Р., Гримак І.Я., Гельнер Н.В., Гижа Б.І., Іваськевич Д.З., Чайківська Е.Ф., Гижа Л.Ю., Стеник Р.В., Дворакевич А.О., Поцюрко Р.А., Глушко 3.I.

Особливості фемінізуючої хірургічної корекції у дітей з розладами статевого розвитку (РСР)

\section{ОРИГІНАЛЬНІ ДОСЛІДЖЕННЯ. ОРТОПЕДІЯ}

69 Гук Ю.М., Зима А.М., Кінча-Полішук Т.А., Чеверда А.І., Скуратов О.Ю., Видерко Р.В. Результати ортопедичного лікування пацієнтів із синдромом Кампаначчі

\section{ОГЛЯДИ}

76 Хоменко В.С., Перепелиия В.П., Кучинський I.О., Сироткін А.В., Хоменко Л.В

Неоклюзивні порушення брижового кровотоку (огляд літератури)

\section{КЛІНІЧНИЙ ВИПАДОК}

84 Боднар О.Б., Боднар Б.М., Іринчин А.В., Пастернак I.I., Рандюк Р.Ю.

Повне подвоєння уретри у хлопчика

з епіспадією

\section{МІЖНАРОДНІ КЛІНІЧНІ}

ПРОТОКОЛИ, РЕКОМЕНДАЦІї

89 Клінічні рекомендації ACG: діагностика та лікування вогнищевих уражень печінки

101 НЕКРОЛОГ
63 Potsiurko A.R., Hrymak I.Ya., Helner N.V., Hyzha B.I., Ivaskevych D.Z., Chaikivska E.F., Hyzha L.Yu., Stenyk R.V., Dvorakevych A.O., Potsiurko R.A., Hlushko Z.I.

Peculiarities of feminizing surgical correction in children with disorders of sexual development

\section{ORIGINAL ARTICLES. ORTHOPEDICS}

69 Guk Y.M., Zyma A.M., Kincha-Polishchuk T.A., Chewerda A.I., Skuratov O.Y., Zotia A.V.

The results of complex treatment of patients with Jaffe-Campanacci syndrome

\section{REVIEWS}

76 Khomenko V.S., Perepelitsia V.P., Kuchynskyi I.O., Sirotkin A.V., Khomenko L.V.

Nonocclusive mesenteric ischemia (literature review)

\section{CLINICAL CASE}

84 Bodnar O.B., Bodnar B.M., Irinchin A.V., Pasternak I.I., Randiuk R.Yu.

Complete duplication of the urethra in a boy with epispadias

\section{THE INTERNATIONAL CLINICAL PROTOCOLS, RECOMMENDATIONS}

89 ACG Clinical Guideline: The Diagnosis and Management of Focal Liver Lesions

101 OBITUARY
Передплатити журнал

«ХІРУРГІЯ ДИТЯЧОГО ВІКУ»

можна в будь-якому відділенні «Укрпошти».

Передплатний індекс

журналу «ХІРУРГІЯ ДИТЯЧОГО ВІКУ» - 60162. 


\section{Шановні колеги!}

Радий вітати Вас на сторінках нашого журналу. Останнім часом проведено визначні науковопрактичні заходи, на яких українські фахівці поділилися досвідом власних досліджень та виробили тактичні підходи до вирішення назрілих проблем практичної діяльності. Згідно з реєстром з'їздів, симпозіумів і науково-практичних конференцій МОЗ та НАМН України 4-5 червня 2021 року проведено I міжнародну фахову школу для дитячих лікарів хірургічних спеціальностей «Практична дитяча хірургія» в рамках III конгресу Української академії педіатричних спеціальностей «PRIME Pediatrics 2021» (м. Київ); 23-24 вересня 2021 року проведено I Науково-практичну конференцію "Охматдитівські читання» (м. Київ); 24-25 вересня 2021 року проведено І відеоконференцію дитячих урологів України з міжнародною участю (м. Одеса).

Серед статей цього номеру особливу увагу привертають роботи А.Ф. Левицького та співавт. «Галогравітаційна тракція при лікуванні складних $\left(>100^{\circ}\right)$ деформацій хребта в дітей із респіраторними дисфункціями»; В.В. Скиби та співавт. "Еволюція діагностики та хірургічного лікування інтраабдомінальних інфрільтратів й абсцесів первинного та післяопераційного походження у хворих». У цих статтях наведено результати лікування нозологій та запропоновано шляхи вирішення проблемних питань щодо лікування і діагностики цих патологій.

Ряд статей присвячено урологічним захворюванням у дитячому віці: О.Д. Фофанов та співавт. «Власний досвід реконструктивно-пластичних операцій на сечовому міхурі в дітей»; Р.А. Наконечний, А.Й. Наконечний «Цистоскопічні особливості вічок сечоводів у дітей з міхурово-сечовідним рефлюксом»; А.Р. Почюрко та співавт. "Особливості фемінізуючої хірургічної корекції в дітей з розладами статевого розвитку». Тематики, обговорені на конференції з актуальних питань дитячої урологічної патології, можуть бути чікавими практикуючим лікарям і науковцям.

Звертаю увагу авторських колективів, що редакція працює над удосконаленням журналу та посилює до наукових статей вимоги, які відповідають європейським науково-метричним виданням. Дякую авторам за надані матеріали.

Запрошую до співпраці. Cтатmі надсилайте на адреcu:pediatr@med-expert.com.ua, або hirurgia1.odl@ukr.net.

3 повагою

профресор Петро Русак

\section{Dear Colleagues!}

We are glad to welcome you on the pages of our journal. Recently, some outstanding scientific and practical events were held, where Ukrainian specialists shared their experience of their own research and offered tactical approaches to solving urgent problems of practical activity. According to the register of congresses, symposia and scientific-practical conferences of the Ministry of Health and the National Academy of Medical Sciences of Ukraine, on June 4-5, 2021, the I International Professional School for Pediatric Surgical Specialties "Practical Pediatric Surgery» was held as part of the III Congress of the Ukrainian Academy of Pediatric Specialties "PRIME Pediatrics 2021» (Kyiv, Ukraine); On September 23-24, 2021, the I Scientific and Practical Conference "Okhmatdyt Readings» (Kyiv, Ukraine) was held; On September 24-25, 2021, the I Video Conference of Ukrainian Pediatric Urologists with international participation was held (Odessa, Ukraine).

Among the articles deserving particular attention in this issue are the articles of A.F. Levytskyi et al. "Halo-gravity traction in the treatment of complex spinal deformities in children with respiratory dysfunctions"; V.V. Skyba et al. "Evolution of diagnosis and surgical treatment of intra-abdominal infiltrates, abscesses of primary and postoperative origin in patients». These articles present the results of treatment of nosologies and suggest ways of solving problematic issues in the treatment and diagnosis of these pathologies.

A number of articles are devoted to urological disease in childhood: O.D. Fofanov et al. "An experience of reconstructive-plastic operations on the bladder in children"; R.A. Nakonechnyy, A.Y. Nakonechnyi "Cystoscopic features of the ureteral orifices in children with vesicoureteral reflux»; A. R. Potsiurko et al. "Peculiarities of feminizing surgical correction in children with disorders of sexual development».

The topics discussed at the conference on relevant issues of pediatric urological pathology may be of interest to practicing doctors and scientists.

We invite you to cooperation. Articles should be sent to pediatr@med-expert.com.ua,or hirurgia1.odl@ukr.net.

Sincerely,

Professor Petro Rusak 


\title{
О.К. Толстанов, М.Є. Маменко, П.С. Русак, В.В. Горелік \\ Перша міжнародна фахова школа для дитячих лікарів хірургічних спеціальностей
}

\author{
Національний університет охорони здоров'я Украӥни імені П.Л. Шупика
}

Згідно з реєстром з'їздів, симпозіумів і науковопрактичних конференцій, МОЗ та НАМН України 4-5 червня 2021 року проведено Першу міжнародну фахову школу для дитячих лікарів хірургічних спеціальностей «Практична дитяча хірургія» у рамках III конгресу Української академії педіатричних спеціальностей «PRIME Pediatrics 2021».

Участь у фаховій школі взяли 326 учасників з усієї України, а також міжнародні гості з Німеччини, Білорусі і Великої Британії.

Цей захід мав величезне значення у світлі реформування медицини в бік європейських стандартів, в яких для лікарів-хірургів найважливішим $€$ практичні вміння і навички. Конференція викликала значний інтерес у масштабах країни, про що свідчить зацікавленість засобів масової інформації цим заходом. У новинах каналу «Україна 24» подію висвітлили з найбільш позитивними коментарями.

У ході відкриття конференції з вітальною промовою виступив проректор з науково-педагогічної роботи Національного університету охорони здоров'я України імені П.Л. Шупика професор Толстанов О.К., який наголосив, що підготовку хірурга неможливо уявити лише в дистанційному форматі без навчання в умовах «реального часу», яке дає змогу відчути до- тик руки, інструменту та оцінити реакцію хірурга в тій чи іншій ситуації. Саме тому проведення цього заходу має передусім практичне спрямування: $з$ теоретичного обгрунтування нових наукових розробок до впровадження їх у практичну діяльність.

На початку конференції згадали вчителів різних хірургічних шкіл України за допомогою презентації, яку символічно підготувала наша молодь і прекрасно доповіла лікар-інтерн Катерина Ячна. Почесним професорам, а також практичним лікарям, які зробили значний внесок у лікування дітей, вручили іменні сертифікати та висловили подяку за багаторічну роботу в галузі дитячої хірургії, ортопедії і травматології та урології.

3 цікавими та професійними доповідями за напрямами в дитячій хірургії, що наразі посідають важливе місце в роботі лікаря дитячого хірурга, виступили Михайло Болгов «Особливості хірургічного лікування патології ендокринної системи у дітей», Олександр Калінчук «Неприємний «сюрприз» для хірурга - пухлина у дитини» і Михайло Андрущенко про медичне право і етико-деонтологічні аспекти.

Сучасними і перспективними напрямами дитячої хірургії $€$ ендоваскулярна хірургія, дитяча трансплантологія, роботизована хірургія і хірургія новонаро-

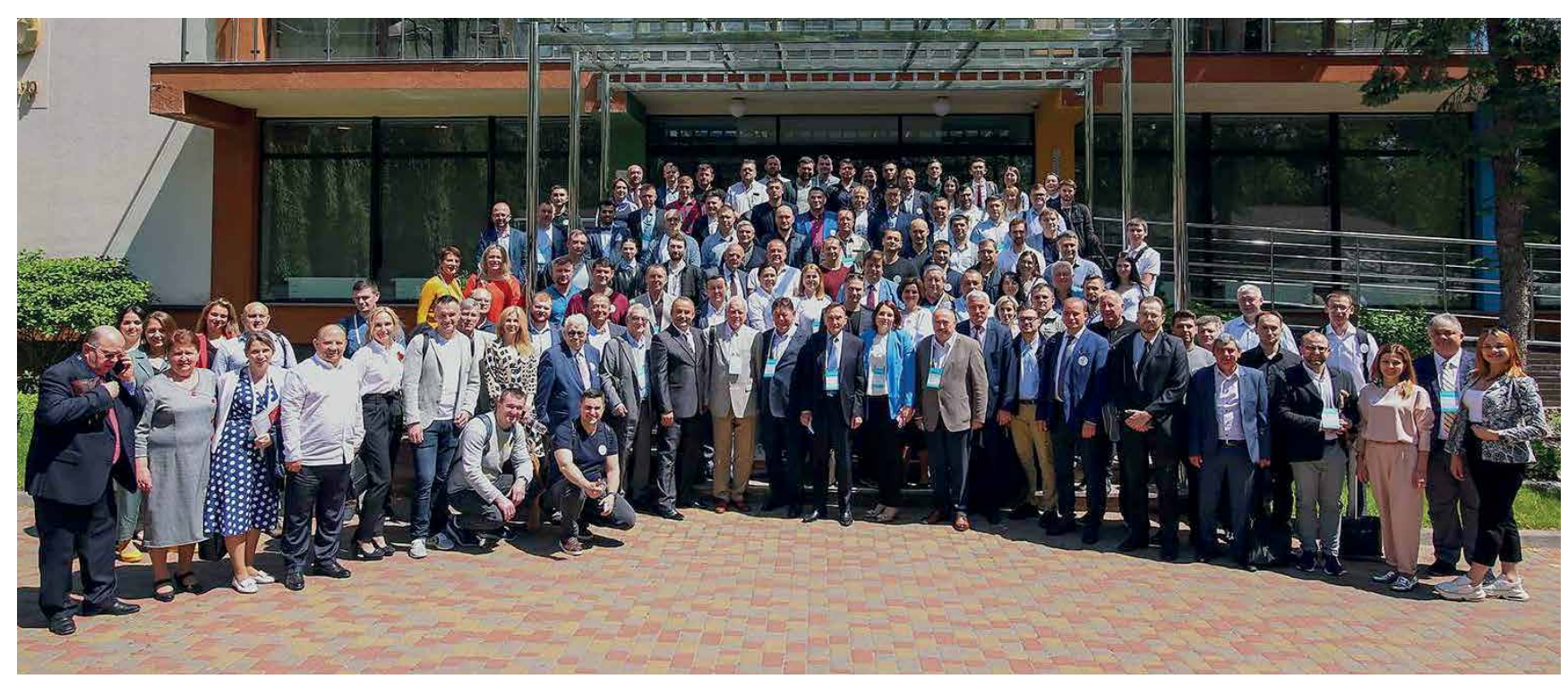

Учасники конференції 
джених з вадами розвитку. Досвідом роботи поділились: Олена Власенко, Олег Годік та Андрій Дворакевич. У перший день робота проходила в трьох секціях за різними напрямами: дитяча хірургія - ургентна і планова, хірургія вад розвитку, дитяча ортопедія, дитяча травматологія і дитяча урологія. Активну участь взяли професори: Давиденко В.Б., Данилов О.А., Діхтяр В.А., Кривчення Д.Ю., Левицький А.Ф., Нагайчук B.I., Притула В.П., Рибальченко В.Ф., Русак П.С., Хмизов С.О., доцент Кузик А.О. Кожний доповідач поділився досвідом роботи різних хірургічних шкіл України та дав практичні рекомендації лікарям.

Майстер-класи та симуляційні тренінги провели Сергій Бідула (світові стандарти лікування переломів у дітей), Петро Русак (лапароскопічна хірургія), Андрій Попченко («золотий стандарт» лікування клишоногості), Олег Шмирьов (пункція і дренування плевральної порожнини), Сергій Рябчун (кадаверкурс із реконструкції сухожиль), Ганна Вовченко (У3діагностика патології кульшових суглобів), Мирослава Петровська (лабораторна діагностика в дитячій хірургіï). Ці практичні заняття були цікавими не тільки молодим, але й досвідченим лікарям, оскільки базуються на нових методиках лікування із застосуванням сучасного обладнання. Усі навики відпрацьовані на 3D-моделях, сучасних симуляційних тренажерах або на тваринному матеріалі. Кожному учаснику видали відповідні сертифікати.

Більш того, учасники конференції акцентували увагу на необхідності розроблення протоколів і їх затвердження на рівні Міністерства охорони здоров’я України. Це допоможе попередити можливі помилки, забезпечити якісну медичну допомогу дітям у регіонах і надати рекомендації для лікарів первинної та вторинної ланок закладів охорони здоров’я України. Також $€$ нагальна потреба налагодити належну організацію проведення хірургічних втручань, складність яких відповідала 6 рівню надання допомоги в лікувально-профілактичних закладах України.

Висловлюємо подяку керівництву Національного університету охорони здоров'я України імені П.Л. Шупика, а також ії підрозділам - симуляційному центру і кафедрі дитячої хірургії, Українській академії педіатричних спеціальностей, Асоціації дитячих лікарів хірургічних спеціальностей, спонсорам і партнерам заходу за можливість після тривалої ізоляції зустрітися з колегами, здобути теоретичні та практичні знання і дружно поспілкуватися.

Усі ми маємо єдину мету - спільними зусиллями боротися за здоров’я маленьких пацієнтів, які є майбутнім України. До наступних зустрічей!

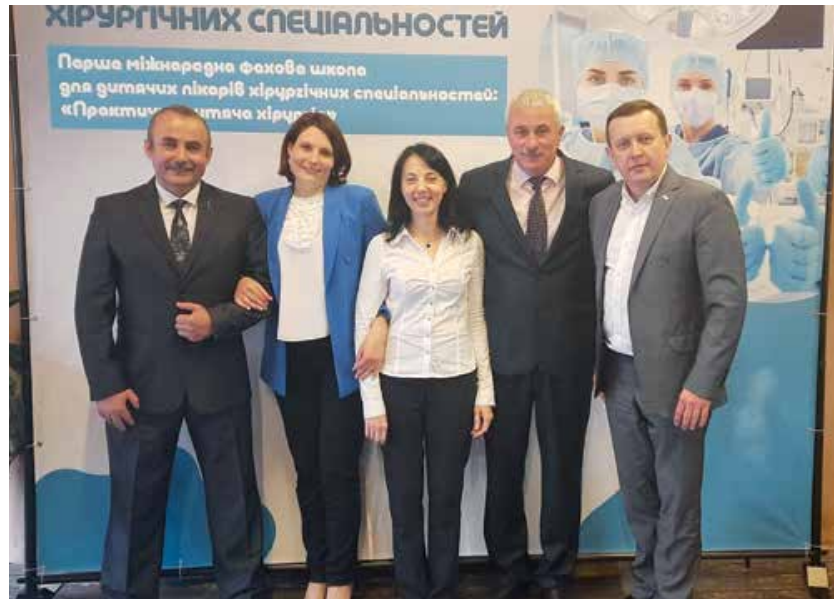

На фото (з ліва на право): В. Притула, В. Горелік, О. Власенко, П. Русак, А. Кузик

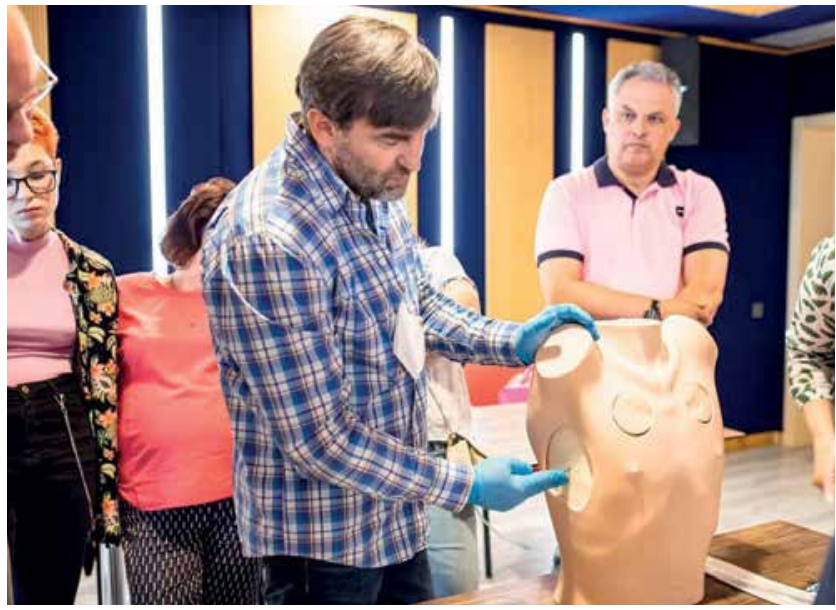

Майстер-клас О. Шмирьова

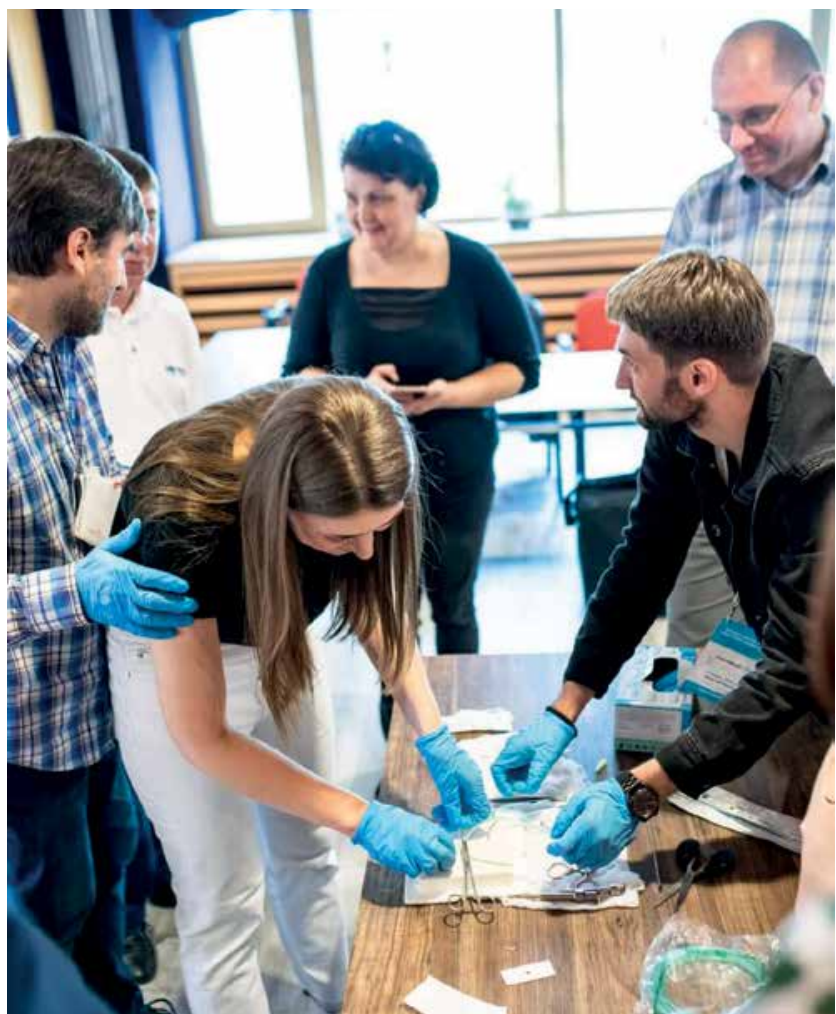

Молоді лікарі на симуляційному тренінгу 


\section{Перша відеоконференція дитячих урологів України з міжнародною участю «Odrex Pediatric Urology Meeting»}

24-25 вересня 2021 рокув м. Одесі відбулася Перша відеоконференція дитячих урологів Украӥни з міжнародною участю "Odrex Pediatric Urology Meeting». Уперше за довгі роки лікарі иього профілю зустрілися на власній конференції, а не були окремою секцією на зустрічах хірургів. Цей захід відбувся в "Medical Ниь Odrex», який є майданчиком для обміну медичнми знаннями на базі Медичного домy «Odrex».

Коло учасників: дитячі урологи, дитячі хірурги, дитячі нефрологи та інші фахівці, задіяні в наданні допомоги дітям з урологічними захворюваннями. Усі учасники мали змогу брати участь в офлайн- та онлайнформатах. На конференції були присутні представники майже всіх областей України.

Протягом двох днів понад 20 спікерів із різних куточків країни та світу висвітлювали актуальні проблеми сучасної дитячої урології, зокрема:

- злоякісна пухлина нирки,

- ендоскопія в діагностиці та лікуванні нервово-м’язової дисфункції сечового міхура в дітей,

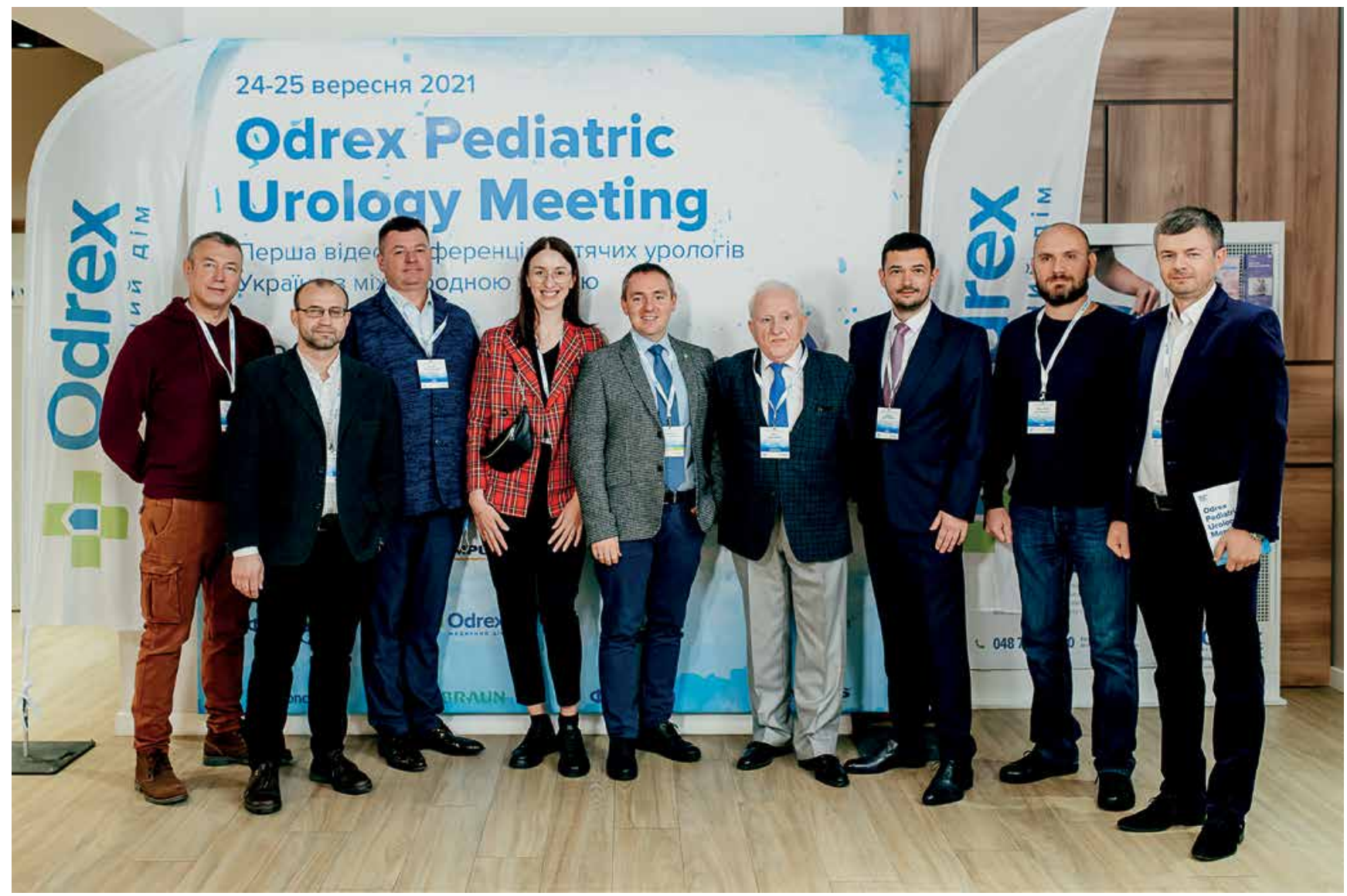

На фото (з ліва на право): Г. Устенко, О. Калінчук, Щ. Каліщук, М. Шпит, Д. Гавриченко, І. Костєв, Д. Чеканов, А. Обертинський, Д. Шевчук 

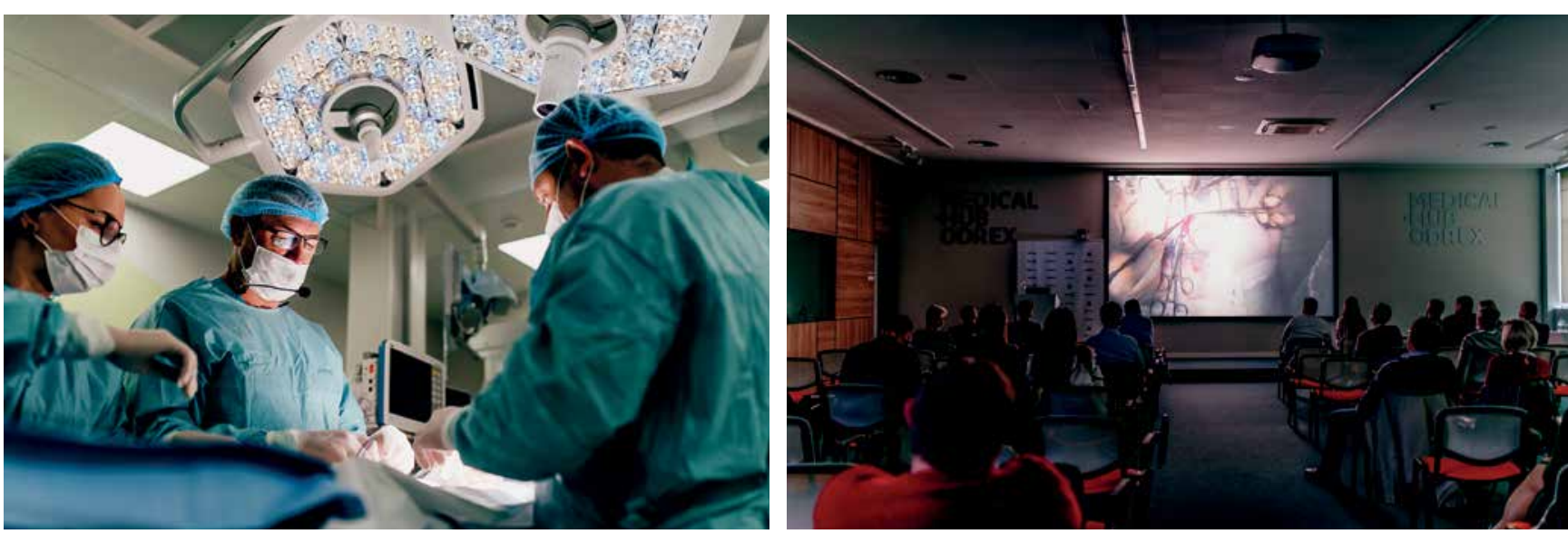

Онлайн-трансляція операції при вадах розвитку уретри у хлопчиків

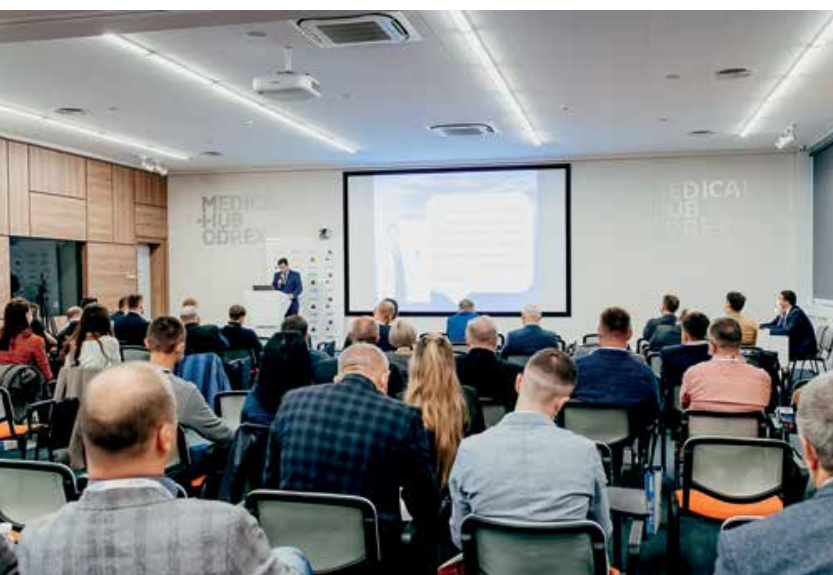

Робочий момент конференції

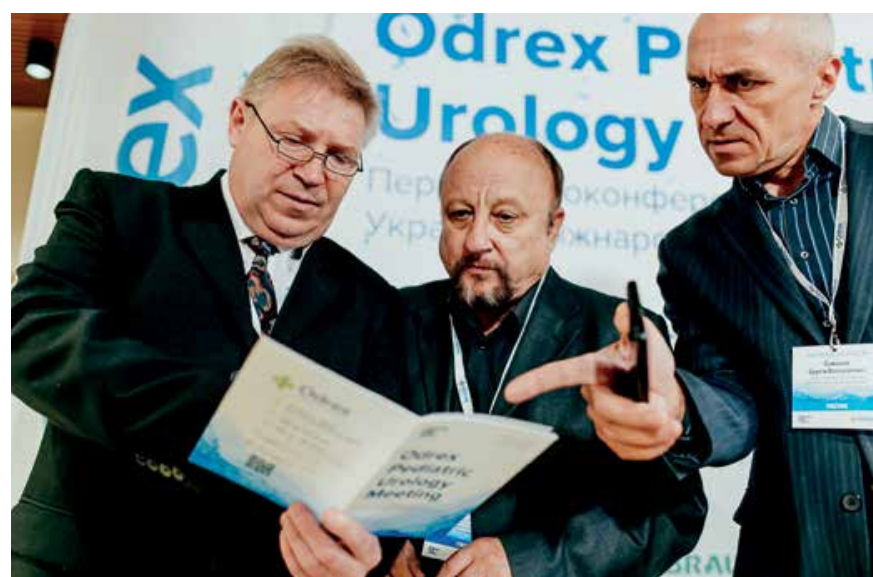

На фото (з ліва на право): доцент Олексій Бухмін, професор Василь Россіхін, дитячий уролог Сергій Суманов

- лікування обструктивного мегауретеру в дітей,

- нейрогенний сечовий міхур,

- рефлюкс-нефропатія в дітей,

- хронічна хвороба нирок у дітей з урологічною патологією,

- особливості вакцинації дітей з хронічними хворобами нирок,

- повне подвоєння уретри у хлопчика з епіспадією,

- ускладнення після ендоскопічної корекції міхурово-сечовідного рефлюкса в дітей,

- особливості проведення мінічерезшкірної нефролітотрипсії в дітей,

- лапароскопічний уретерокалікоанастомоз при рецидивній протяжній стриктурі пієлоуретерального сегмента в дітей,

- досвід лікування пацієнта з метастатичним раком яєчка після крипторхізму з групи несприятливого прогнозу та багато іншого.

Ділилися клінічними випадками, перевагами мінінвазивного лікування, говорили про трансплантологію та проводили «живу» хірургію. Операція при вадах розвитку уретри у хлопчиків під назвою «гіпоспадія» проходила з онлайн-трансляцією. Учасники могли спостерігати за процесом втручання в операційному полі розміром 1,5 cм, ставити питання та дізнаватися нову і важливу інформацію для лікування своїх пацієнтів.

Більшість учасників зазначили, що обміну інформацією між колегами справді не вистачало. Тому наприкінці конференції учасники порушили питання створення Асоціації дитячих урологів України. 


\title{
А.Ф. Левицький ${ }^{1}$ В.О. Рогозинський ${ }^{1,2}$, М.М. Доляницький ${ }^{1,2}$, Л.В. Дуда \\ Гало-гравітаційна тракція при лікуванні складних $\left(>100^{\circ}\right)$ деформацій хребта в дітей із респіраторними дисфункціями
}

\author{
${ }^{1}$ Національний медичний університет імені О.О. Богомольия, м. Київ, Україна \\ ${ }^{2}$ Національна дитяча спеціалізована лікарня «Охматдит», м. Київ, Україна \\ ${ }^{3}$ Національний університет охорони здоров'я Украйни імені П.Л. Шупика, м. Київ, Украӥна
}

Paediatric surgery.Ukraine.2021.3(72):10-14; doi 10.15574/PS.2021.72.10

For citation: Levytskyi AF, Rogozinskyi VO, Dolianytskyi MM, Duda LV. (2021). Halo-gravity traction in the treatment of complex spinal deformities in children with respiratory dysfunctions. Paediatric Surgery.Ukraine. 3(72):10-14; doi 10.15574/PS.2021.72.10.

Гало-гравітаційна тракція (ГГТ) є безпечною методикою, оскільки у світовій літературі описано ускладнення у вигляді розхитування штифтів або поверхневі інфекції шкіри навколо штифтів, які є несуттєвими та не загрожують життю пацієнта. Застосування ГГТ дає змогу поліпшити вентиляційну функцію легень, а це, своєю чергою, сприяє зниженню ризиків смертності внаслідок легеневої недостатності в дорослому віці.

Мета - поліпшити результати вентиляційної функції легень за рахунок попереднього застосування ГГТ у пацієнтів зі складними деформаціями хребта; встановити ефективний і безпечний алгоритм лікування складних деформацій хребта в дітей з респіраторними дисфункціями.

Матеріали та методи. За період 2003-2018 рр. в ортопедо-травматологічному відділенні НДСЛ «Охматдит» проведено лікування 64 дітей зі складними деформаціями хребта $\left(>100^{\circ}\right)$ із застосуванням ГГТ. 3 них 38 хлопчиків і 26 дівчаток. Середній вік пацієнтів становив 11,6 року. Середній показник тесту Ріссера $3,8(\mathrm{P}>0,01)$.

Результати. За даними спірографії, 46\% пацієнтів мали помірні вентиляційні порушення, а 54\% - тяжкі (ФЖЄЛ $<60 \%$ - 3 і 4-го ступеня вентиляційної недостатності). У 83\% пацієнтів зареєстрували порушення змішаного типу, а в $17 \%$ (8/48) дітей - рестриктивного типу. Після ретракції виявили поліпшення показників легеневої функції: зростання ФЖЄЛ із 63,19\% до 71,77\%, ОФВ - із 54,71\% до 65,46\%, індексу Тиффно - із 74,59\% до 85,33\%. Порівняно з вихідним рівнем показників, поліпшення за ФЖЄЛ становило 13,6\% після ГГТ та 14,6\% у динаміці за 1 рік після неї, а за ОФВ 1 - 19,6\% та 21,6\% відповідно. Отримані результати свідчать про значне поліпшення вентиляційної функції легень, особливо за рахунок ступеня зростання ОФВ зі ступенем підвищення працездатності, смертністю та життєвим прогнозом.

Висновки. Застосування ГГТ дає змогу поліпшити результати остаточної корекції деформації хребта, а це значно покращує вентиляційну функцію легень, що, своєю чергою, сприяє зниженню ризиків смертності внаслідок легеневої недостатності в дорослому віці.

Вибір оптимальної тактики хірургічної корекції складної деформації хребта $є$ необхідною умовою успішного лікування та досягнення тривимірної корекції хребта для максимального приближення його параметрів до фізіологічної норми.

Показанням до проведення ГГТ є ригідна деформація хребта з кутом деформації $\left(>100^{\circ}\right)$.

Дослідження виконано відповідно до принципів Гельсінської декларації. Протокол дослідження ухвалено Локальним етичним комітетом зазначених у роботі установ. На проведення дослідження отримано інформовану згоду батьків дітей.

Автори заявляють про відсутність конфлікту інтересів.

Ключові слова: деформація хребта, респіраторні дисфункції, гало-гравітаційна тракція. 
Halo-gravity traction in the treatment of complex spinal deformities in children with respiratory dysfunctions A.F. Levytskyi ${ }^{1}$, V.O. Rogozinskyi ${ }^{1,2}$, M.M. Dolianytskyi ${ }^{1,2}$, L.V. Duda ${ }^{3}$

${ }^{1}$ Bogomolets National Medical University, Kyiv, Ukraine

${ }^{2}$ National Children's Specialized Hospital «Ohmatdyt», Kyiv, Ukraine

${ }^{3}$ Shupyk National Healthcare University, Kyiv, Ukraine

HGT is a safe technique as the world literature describes complications in the form of loosening of the pins or superficial infections of the skin around the pins, which are not significant and do not pose a threat to the patient's life.

Purpose - to improve the results of the ventilation function of the lungs in patients with complex spinal deformities through the preliminary use of halo gravity traction and to introduce an effective and safe method for the treatment of complex spinal deformities in children with respiratory dysfunctions. Materials and methods. 64 children with complex spinal deformities $\left(>100^{\circ}\right)$ were treated in the orthopedic and traumatology department of the Okhmatdet NSPU using halo gravity traction during the period from 2003 until 2018. Of these, 38 are boys and 26 are girls. The average age of the patients was 11.6 years. The average Risser score was $3.8(P>0.01)$.

Results. According to the data of spirography performed, $46 \%$ of patients had moderate ventilation disorders and $54 \%$ - severe ventilation disorders (FVC $<60 \%$ - grade 3 and 4 of ventilation failure). Mixed type disorders were recorded in $83 \%$ of patients, and restrictive type disorders in 17\% (8/48) of children. After HGT, there was an improvement in pulmonary function indicators: an increase in FVC from $63.19 \%$ to $71.77 \%$ and $\mathrm{FEV}$, from $54.71 \%$ to $65.46 \%$, Tiffeneau-Pinelli index - from $74.59 \%$ to $85.33 \%$. Compared with the initial level of indicators, the improvement in FVC was $13.6 \%$ after HGT and $14.6 \%$ in dynamics during the year, and $\mathrm{FEV}_{1}-19.6 \%$ and $21.6 \%$, respectively. The results obtained indicate a significant improvement in the ventilation function of the lungs, especially due to the degree of $\mathrm{FEV}_{1}$ increase, which correlates with the degree of improvement in performance, mortality and life prognosis.

Conclusions. The use of HGT makes it possible to improve the results of the final correction of spinal deformity, which in turn significantly improves the ventilation function of the lungs, which in turn helps to reduce the risks of mortality due to pulmonary insufficiency in adulthood.

The choice of the appropriate methods of surgical correction for complex deformity of the spine is a prerequisite for successful treatment and the achievement of three-dimensional correction of the spine to maximally approximate its parameters to the physiological norm. The indication for halo gravity traction is a rigid scoliotic deformity of the spine with a deformity angle $\left(>100^{\circ}\right)$.

This study was conducted in accordance with the principles of the Helsinki Declaration. The research protocol was approved by the Local Ethics Committee of the institutions mentioned in the work. Informed parental agreement was obtained for the research.

No conflict of interests was declared by the authors.

Key words: spinal deformity, respiratory dysfunctions, halo-gravity traction.

\section{Гало-гравитационная тракция при лечении сложных (>100) деформаций позвоночника у детей с респираторными дисфункциями}

\section{А.Ф. Левицкий ${ }^{1}$, В.А. Рогозинский ${ }^{1,2}$, Н.М. Доляницкий ${ }^{1,2}$, Л.В. Дуда ${ }^{3}$}

${ }^{1}$ Национальный медицинский университет имени А.А. Богомольца, г. Киев, Украина

${ }^{2}$ Национальная детская специализированная больница "Охматдет», г. Киев, Украина

${ }^{3}$ Национальный университет здравоохранения Украины имени П.Л. Шупика, г. Киев, Украина

Гало-гравитационная тракция (ГГТ) является безопасной методикой, поскольку в мировой литературе описывают осложнения в виде расшатывания штифтов или поверхностные инфекции кожи вокруг штифтов, являющиеся несущественными и не создающими угрозу жизни пациента. Использование ГГТ позволяет улучшить вентиляционную функцию легких, что, в свою очередь, способствует снижению рисков смертности вследствие легочной недостаточности во взрослом возрасте.

Цель - улучшить результаты вентиляционной функции легких за счет предварительного применения ГГТ у пациентов со сложными деформациями позвоночника; внедрить эффективный и безопасный алгоритм лечения сложных деформаций позвоночника у детей с респираторными дисфункциями. Материалы и методы. За период 2003-2018 гг. в ортопедо-травматологическом отделении НДСБ «Охматдет» проведено лечение 64 детей со сложными деформациями позвоночника $\left(>100^{\circ}\right)$ с применением ГГТ. Из них - 38 мальчиков и 26 девочек. Средний возраст пациентов составил 11,6 года. Средний показатель теста Риссера $-3,8$ (Р>0,01).

Результаты. По данным проведенной спирографии, 46\% пациентов имели умеренные вентиляционные нарушения и $54 \%$ - тяжелые (ФЖЕЛ <60\% - 3 и 4-й степени вентиляционной недостаточности). У $83 \%$ пациентов регистрировались нарушения смешанного типа, а у $17 \%(8 / 48)$ детей - рестриктивного типа. После ГГТ отмечалось улучшение показателей легочной функции: повышение ФЖЕЛ с 63,19\% до 71,77\% и ОФВ с 54,71\% до 65,46\%, индекса Тиффно - с 74,59\% до 85,33\%. По сравнению с исходным уровнем показателей, улучшение по ФЖЕЛ составило 13,6\% после ГПТ и 14,6\% в динамике за год, а ОФВ 1 - 19,6\% и 21,6\% соответственно. Полученные результаты свидетельствуют о значительном улучшении вентиляционной функции легких, особенно за счет степени роста ОФВ 1 , что коррелирует со степенью улучшения работоспособности, смертностью и жизненным прогнозом.

Выводы. Применение ГГТ позволяет улучшить результаты окончательной коррекции деформации позвоночника, а это значительно улучшает вентиляционную функцию легких, что, в свою очередь, способствует снижению рисков смертности из-за легочной недостаточности во взрослом возрасте. Выбор оптимальной тактики хирургической коррекции при сложной деформации позвоночника является необходимым условием успешного лечения и достижения трехмерной коррекции позвоночника для максимального приближения его параметров к физиологической норме. Показанием к проведению ГГ является ригидная деформация позвоночника с углом деформации $\left(>100^{\circ}\right)$.

Исследование выполнено в соответствии с принципами Хельсинкской декларации. Протокол исследования одобрен Локальным этическим комитетом указанных в работе учреждений. На проведение исследования получено информированное согласие родителей детей.

Авторы заявляют об отсутствии конфликта интересов.

Ключевые слова: деформация позвоночника, респираторные дисфункции, гало-гравитационная тракция.

\section{Вступ}

Визначення «складної деформації хребта» залишається нечітким, але в більшості публікацій її зазначають як деформацію, що перевищує $100^{\circ}[3]$.

Гало-гравітаційна тракція (ГГТ) є безпечною та ефективною методикою для попереднього коригування складних деформацій хребта до проведення корекції в обсязі - задньої інструментації хребта [1,4,6-9].

Цю методику використовують при складних деформаціях хребта в Texas Scottish Rite Hospital з 1987 року. ГГТ як попередній етап перед виконанням задньої інструментації хребта дає змогу здійсню- 
вати контрольовану поступову корекцію деформації в пацієнта, чим забезпечує зниження ризику гострих неврологічних порушень.

Гало-гравітаційна тракція є безпечною методикою, оскільки у світовій літературі описують ускладнення у вигляді розхитування штифтів або поверхневі інфекції шкіри навколо штифтів, які є несуттєвими та не загрожують життю пацієнта $[1,6]$. Застосування ГГТ дає змогу поліпшити вентиляційну функцію легень, що, своєю чергою, сприяє зниженню ризиків смертності внаслідок легеневої недостатності в дорослому віці.

Мета дослідження - поліпшити результати вентиляційної функції легень за рахунок попереднього застосування ГГТ у пацієнтів зі складними деформаціями хребта; встановити ефективний і безпечний алгоритм лікування складних деформацій хребта в дітей з респіраторними дисфункціями.

\section{Матеріали та методи дослідження}

Критерії залучення до дослідження - будь-яка виражена $\left(>100^{\circ}\right)$ деформація хребта, за рідкісними винятками, зазначеними нижче.

Критерії вилучення з дослідження - наявність сигінгомієлії, діастематомієлії, мальформації Арнольда Kiapi, внутрішньо- / екстрадурального ураження (пухлина) або тяжких локалізованих стенозів каналу 3 неврологічним дефіцитом або без нього.

За період 2013-2018 рр. в ортопедо-травматологічному відділенні НДСЛ «Охматдит» проведено лікування 64 дітей зі складними деформаціями хребта $\left(>100^{\circ}\right)$ із застосуванням ГГТ. 3 них було 38 хлопчиків і 26 дівчаток. Середній вік пацієнтів становив 11,6 року. Середній показник тесту Ріссера - 3,8 (P>0,01).

До дослідження залучено тільки дітей зі складними деформаціями хребта $>100^{\circ}$. Середня корекція фронтальної і сагітальної площини при ГГТ становить 20-35\% і 25\% відповідно.

Під час дослідження враховано вік, стать, тип деформації, обсяг оперативного втручання, найближчі та віддалені результати оперативного лікування (1-3 роки). Кут деформації становив у середньому $108,16 \pm 3,46^{\circ}(\mathrm{P}>0,01)$.
У 48 (70,59\%) пацієнтів (Р>0,01) лікування проведено після завершення інтенсивного росту хребта, про що свідчить середній показник тесту Ріссера, CRITOE-тест, рентгенологічні дослідження осифікації ліктьового відростка, тесту Танера.

Усі хірургічні втручання виконано одним хірургом.

Досліджено неврологічний статус, застосовано променеві методи дослідження (рентгенографія в стандартних площинах, тракційний тест, тест із нахилом, комп'ютерна томографія (КТ), магнітно-резонансна томографія (МРТ) хребта). На підставі даних КТ і МРТ хребта оцінено наявність можливих вроджених вад хребта та спинного мозку. За даними рентгенографії оцінено фронтальний, сагітальний баланс, визначено кут деформації за Cobb. На рентгенограмах хребта в боковій площині із захватом кульшових суглобів і дротовим виском, який центрується від остистого паростка C VII у положенні пацієнта стоячи, визначено величину грудного кіфозу, поперекового лордозу, скошеності та нахилу таза й крижа.

Патологічну ротацію і торсію хребців виміряно на вершині грудного та поперекового викривлення за допомогою КТ.

Оцінку функціонального стану серцево-судинної та респіраторної систем організму в дітей проведено за допомогою спірографії, електронейроміографії м'язів кінцівок (електрофізіологічні методи дослідження), електрокардіографії, ехокардіографії. Зокрема, дітям проведено дослідження вентиляційної функції легень на етапах: до та після ГГТ, після задньої інструментації хребта, а також у динаміці за 1 рік і за 3 роки. Із 3 повторюваних спроб з 6, які відрізнялися не більше ніж на 5\% за показниками форсованої життєвої ємності легень (ФЖЄЛ) та об’єму форсованого видиху за першу секунду $\left(О Ф B_{1}\right)$ обрано кращу спробу. Проаналізовано кількісні показники - об’ємні та швидкісні - ФЖЄЛ (FVC),

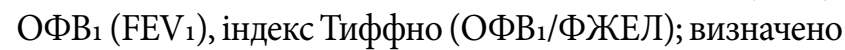
тип вентиляційної недостатності та їі тяжкість згідно 3 рекомендаціями Європейського респіраторного товариства і Американського торакального товариства.

Величину декомпенсації тулуба відносно крижа визначено шляхом вимірювання дистанції, на яку змістився дротовий висок.

\section{Таблиця}

Оцінка показників вентиляційної функції легень до та після гало-гравітаційної тракції, після задньої інструментації хребта і в динаміці за один рік і три роки (\%)

\begin{tabular}{|l|l|l|l|}
\hline Показник & ФЖЄЛ (FVC) & ОФВ $(\mathbf{F E V} \mathbf{1})$ & Індекс Тиффно \\
\hline До ГГТ & $63,19 \pm 9,39(59,0-67,75)$ & $54,71 \pm 9,85(47,0-63,25)$ & $74,59 \pm 11,78(70,0-81,47)$ \\
\hline Після ГГТ & $71,77 \pm 9,55(66,0-78,25)$ & $65,46 \pm 9,18(59,0-70,25)$ & $85,33 \pm 10,27(81,52-89,42)$ \\
\hline За 1 рік & $72,43 \pm 8,83(67,0-78,0)$ & $66,60 \pm 7,63(61,75-70,0)$ & $86,18 \pm 9,42(82,46-90,17)$ \\
\hline За 3 роки & $72,83 \pm 8,16(67,0-78,0)$ & $67,08 \pm 7,41(62,0-70,0)$ & $86,27 \pm 9,87(82,62-90,47)$ \\
\hline
\end{tabular}




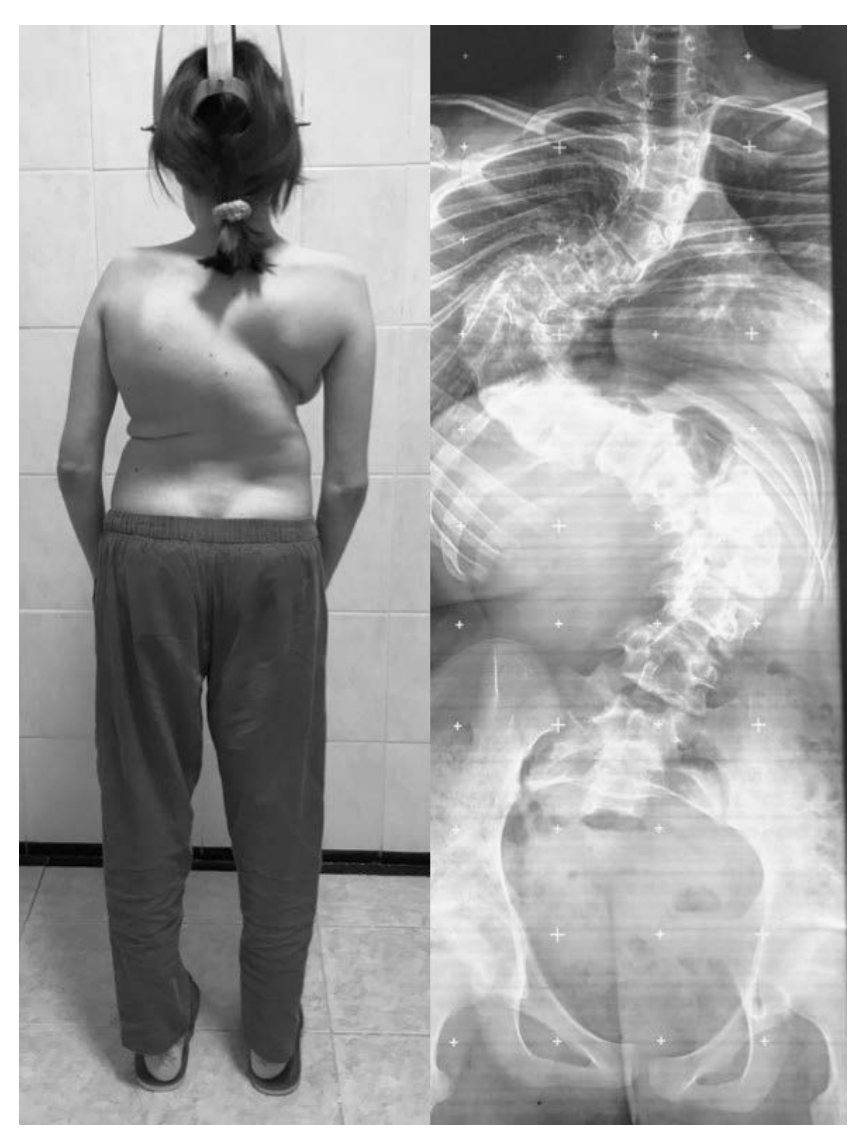

Рис. 1. Загальний вигляд та фотовідбитки рентгенограм пацієнта P. (15 років) з ідіопатичним грудо-поперековим сколіозом: основна дуга $-103^{\circ}$ (до оперативного втручання)

Середня тривалість застосування ГГТ хребта становила $\pm 39(\mathrm{P}>0,01)$ діб. Пацієнти щодня виконували дихальні вправи. Легеневу функцію виміряно у двох часових точках: до і після ГГТ.

ГГТ застосовано в інвалідному візку або в стоячому апараті. Неврологічні обстеження проведено щодоби.

Біль у ділянці шийного відділу хребта без радикулопатії також $€$ поширеним явищем, яке вказує на межу допустимої ваги. Будь-який пацієнт із сильним болем ушиї або порушенням неврологічного статусу тимчасово знімається із системи ГГТ, доки симптоми не поліпшаться.

Дослідження виконано відповідно до принципів Гельсінської декларації. Протокол дослідження погоджено Локальним етичним комітетом для всіх, хто брав участь. На проведення обстеження та лікування дітей отримано інформовану згоду батьків.

\section{Результати дослідження та їх обговорення}

У разі застосування ГГТ для передопераційного зменшення деформації хребта (рис.1), поліпшення результатів вентиляційної функції легень і профілактики неврологічних порушень середня тривалість тракції хребта становила $\pm 39(\mathrm{P}>0,01)$ діб. Використовувалося 35-50\% від маси тіла пацієнта. Максимальна вага до-

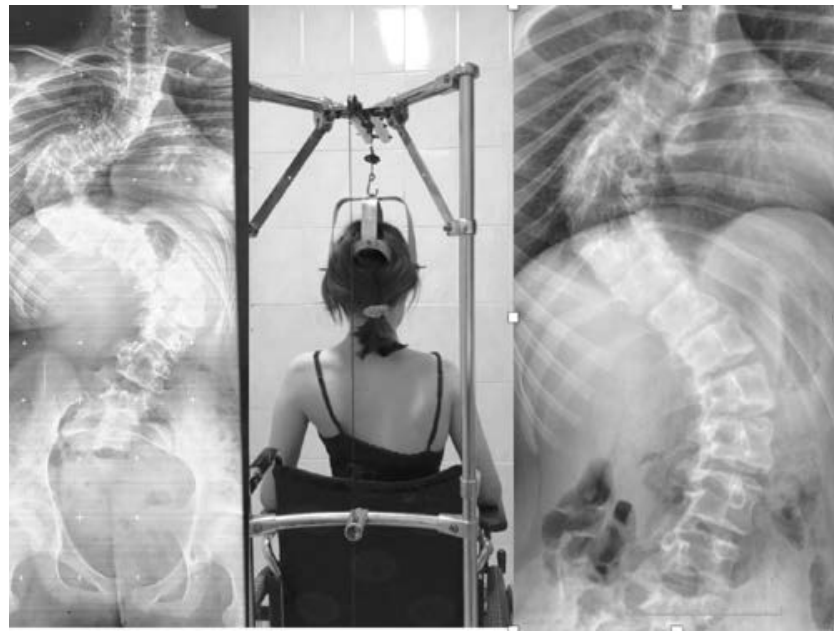

Рис. 2. Загальний вигляд та фотовідбитки рентгенограм пацієнта $P$. (15 років) з ідіопатичним грудо-поперековим сколіозом до оперативного втручання на етапі гало-гравітаційної тракції, корекція - до $78^{\circ}$

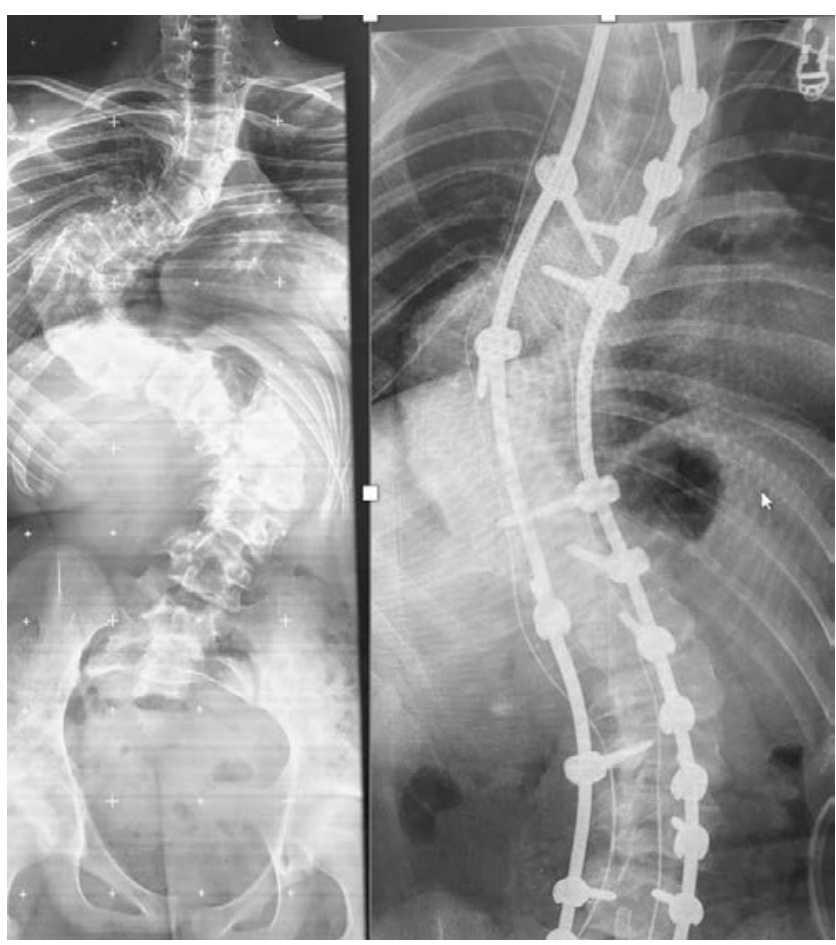

Рис. 3. Фотовідбитки рентгенограм пацієнта Р. (15 років) з ідіопатичним грудо-поперековим сколіозом: $42^{\circ}$ після задньої інструментації хребта

сягалася протягом перших $7 \pm 4$ діб ГГТ. За даними етапних рентгенографій хребта (рис. 2), у разі ГГТ максимальна корекція деформації спостерігалася на 23-гу ( \pm 4 добу. 3 26-ї ( \pm 5$)$ доби суттєвої корекції деформації не відмічалося. Після ГГТ виконувалася стабілізація хребта полісигментарною конструкцією (рис. 3).

Середня корекція деформації хребта становила $62 \pm 8 \%$.

За даними проведеної спірографії, у 46\% пацієнтів спостерігалися помірні вентиляційні порушення, а в $54 \%$ - тяжкі (ФЖЄЛ $<60 \%$ - 3 та 4-го ступеня вентиляційної недостатності). У 83\% пацієнтів реєструвалися 
порушення змішаного типу, а в 17\% (8/48) дітей - рестриктивного типу. Після ретракції відмічалося поліпшення показників легеневої функції: зростання ФЖЄЛ з 63,19\% до 71,77\%, ОФВ 1 - $354,71 \%$ до 65,46\%, індексу Тиффно - 3 74,59\% до 85,33\%. Порівняно з вихідним рівнем показників, поліпшення за ФЖЄЛ становило 13,6\% після ГГТ та 14,6\% у динаміці за 1 рік, а за ОФВ $-19,6 \%$ і 21,6\% відповідно (табл.).

Інтраопераційна крововтрата становила $20 \pm 10 \%$ ОЦК, у всіх випадках використовувалася система для аутогемотрансфузї Cell Saver. Середня тривалість оперативного втручання дорівнювала 375 хв. Транзиторний неврологічний дефіцит спостерігався у $5(7,8 \%)$ пацієнтів, а в 4 (6,2\%) дітей відмічалося запалення м'яких тканин навколо стрижня.

Пацієнтам проведено суб'єктивну оцінку результатів лікування шляхом опитування SRS - 30. Результати анкетування становили >800 балів, а це доводить ефективність і безпечність застосування ГГТ у системі хірургічного лікування складних деформацій у дітей.

При ригідних деформацій хребта у дітей з кутом деформації $\left(>100^{\circ}\right)$ доцільною тактикою лікування є етапне хірургічне втручання, що включає використання системи ГГТ першим етапом, що дає змогу збільшити мобільність хребта, зменшити кут деформації та підготувати пацієнта до задньої інструментації хребта зі значним зниженням ризиків неврологічних порушень.

Вибір оптимальної тактики хірургічної корекції складної деформації хребта є необхідною умовою успішного лікування та досягнення тривимірної корекції хребта для максимального приближення його параметрів до фізіологічної норми.

При використанні системи ГГТ відбувається значне поліпшення вентиляційної функції легень, особливо за рахунок ступеня зростання ОФВ ступенем підвищення працездатності, смертністю та життєвим прогнозом.

\section{Висновки}

Застосування ГГТ дає змогу поліпшити результати остаточної корекції деформації хребта, а це значно покращує вентиляційну функцію легень, що, своєю чергою, знижує ризики смертності внаслідок легеневої недостатності в дорослому віці.

Показанням до проведення ГГТ є ригідна деформація хребта з кутом деформації $\left(>100^{\circ}\right)$.

Застосування першим етапом ГГТ у лікуванні складних деформацій хребта дає змогу збільшити мобільність хребта і поступово адаптувати спинний мозок до подальшої корекції, що зменшує ризики неврологічних ускладнень після хірургічного лікування, скорочує час втручання та об’єм крововтрати, дає змогу отримати кращі результати корекції.

Вибір обсягу хірургічного втручання проводиться, враховуючи анатомічні та функціональні критерії.

Автори заявляють про відсутність конблікту інтересів.

\section{References/Лiтература}

1. Bouchoucha S, Khelifi A, Saied W et al. (2011). Progressive correction of severe spinal deformities with halo-gravity traction. Acta Orthop Belg. 77: 529e34.

2. Garabekyan T, Hosseinzadeh P, Iwinski HJ, Muchow RD, Talwalkar VR, Walker J, Milbrandt TA. (2014). The results of preoperative halo-gravity traction in children with severe spinal deformity. J Pediatr Orthop B. 23: 1-5.

3. Levytskyi A, Rogozinskyi V, Dolianytskyi M. (2020). Paediatric surgery. Ukraine. 4 (69): 67-71.

4. Nemani VM, Kim HJ, Bjerke-Kroll BT et al. (2015). Preoperative halo-gravity traction for severe spinal deformities at an SRS-GOP Site in West Africa: protocols, complications, and results. Spine. 40: $153 \mathrm{e} 61$.

5. Okhotnikova OM, Tkachova TM, Rudenko SM. (2014). Funktsionalni metody doslidzhennia orhaniv dykhannia u ditei: 95 . [Охотнікова ОМ, Ткачова ТМ, Руденко СМ. (2014). Функціональні методи дослідження органів дихання у дітей: 95].

6. Rinella A, Lenke L, Whitaker C et al. (2005). Perioperative halogravity traction in the treatment of severe scoliosis and kyphosis. Spine (Phi- la Pa 1976). 30: 475e82.

7. Sink EL, Karol LA, Sanders J et al. (2001). Efficacy of perioperative halo- gravity traction in the treatment of severe scoliosis in children. J Pediatr Orthop. 21: 19e524.

8. Yang C, Wang H, Zheng Z, Zhang Z, Wang J, Liu H et al. (2017). Halo-gravity traction in the treatment of severe spinal deformity: a systematic review and meta-analysis. Eur Spine J. 26 (7): 1810-1816.

9. Zhang ZX, Hui H, Liu TJ, Zhang ZP, Hao DJ. (2016). Two-staged correction of severe congenital scoliosis associated with intraspinal abnormalities. Clin Spine Surg. 29 (8): E401-405.

\footnotetext{
Відомості про авторів:

Левицький Анатолій Феодосійович - д.мед.н., проф., зав. каф. дитячої хірургї НМУ імені О.О. Богомольия. Адреса: м. Київ, бульвар Т. Шевченка, 13; тел. (044) 236-51-80. https://orcid.org/0000-0002-4440-2090.

Рогозинсвкий Валентин Олександрович - аспірант каф. дитячої хірургії НМУ імені О.О. Богомольия, лікар ортопед-травматолог дитячий відділення ортопедї та травматології НДСЛ «ОХМАТДИТ». Адреса: м. Київ, вул. В. Чорновола, 28/1. https://orcid.org/0000-0001-9891-0739.

Доляницький Микола Михайлович - аспірант каф. дитячої хірургї НмУ імені О.О. Богомольия, лікар ортопед-травматолог дитячий відділення ортопедії та травматологї НДСЛ «ОХМАТДИТ». Адреса: м. Київ, вул. В. Чорновола, 28/1. https://orcid.org/0000-0002-0898-6914.

Дуда Людмила Володимирівна - к.мед.н., асистент каф. педіатрії 1 НУОЗ України імені П.Л. Шупика, лікар педіатр дитячий відділення педіатріі НДСЛ «ОХМАТДИТ». Адреса: м. Київ, вул. В. Чорновола, 28/1. https://orcid.org/0000-0002-4299-9356.
} 


\title{
В.В. Скиба ${ }^{1,3,4}$, В.Ф. Рибальченко ${ }^{2,3}$, О.В. Іванько ${ }^{1,3,4}$, Р.М. Борис ${ }^{3}$, Дар Ясін Ахмед ${ }^{3}$, В.В Лисиця \\ Еволюція діагностики та хірургічного лікування хворих на інтраабдомінальні інфільтрати й абсцеси первинного та післяопераційного походження
}

\author{
${ }^{1}$ Національний медччнии університет імені О.О. Богомольия, м. Київ, Україна \\ ${ }^{2}$ Національний університет охорони здоров'я Украӥни імені П.Л. Шупика, м. Київ, Україна \\ ${ }^{3} \Pi$ ПНЗ «Київський медичний університет», Украӥна \\ ${ }^{4}$ КНП «Київська міська клінічна лікарня № 1», Україна
}

Paediatric surgery.Ukraine.2021.3(72):15-29; doi 10.15574/PS.2021.72.15

For citation: Skyba VV, Rybalchenko VF, Ivanko AV, Borys RM, Dar Yasinya Akhmed, Lysytsa VV. (2021). Evolution of diagnosis and surgical treatment of intraabdominal infiltrates, abscesses of primary and postoperative origin in patients. Paediatric Surgery.Ukraine. .3(72):15-29; doi 10.15574/PS.2021.72.15.

Мета - поліпшити результати хірургічного лікування хворих з інтраабдомінальними інфільтратами й абсцесами за рахунок впровадження інформативних методів візуалізації та хірургічних технологій.

Матеріали та методи. У клініці кафедри хірургічних хвороб № 1 на базі центру хірургії Київської міської клінічної лікарні № 1 у період 2006-2019 рр. перебували на лікуванні 218 пацієнтів із первинними та вторинними інтраабдомінальними інфільтратами й абсцесами. Вік пацієнтів становив від 16 до 85 років. Серед пацієнтів було 107 (49,08\%) чоловіків і 11 (50,92\%) жінок. Залежно від часу шпиталізації (по роках) хворих поділено на дві групи: контрольна група (2006-2012 рр.) - 117 (53,67\%) хворих; досліджувана група (20132019 рр.) - 101 (46,33\%) хворий. У досліджуваній групі використано візуалізаційні технології та вдосконалені методики хірургічного лікування.

Результати. Хворих поділено на дві групи залежно від розвитку недуги та проведення лікування: первинні інфільтрати й абсцеси - у 191 (87,61\%), вторинні післяопераційні - у 27 (12,39\%) осіб. Причинами виникнення первинних інфільтратів й абсцесів були: ускладнені форми апендициту - у 74 (33,94\%), перфоративна виразка шлунка і дванадцятипалої кишки - у 48 (22,02\%), ускладнені форми холециститу у 69 (31,65\%) пацієнтів. Післяопераційні інфільтрати й абсцеси відмічалися у 27 (12,39\%) хворих, які перенесли ургентні операції: адгеолізис спайкової непрохідності - у 14 (6,42\%), ускладнені грижі різної локалізації - у 13 (5,97\%). Післяопераційні ускладнення діагностувалися у 43 (19,72\%) хворих, з яких із боку операційної рани - у 34 (15,59\%), черевної порожнини - у 29 (15,18\%), ці ускладнення потребували релапаротомії чи лапароскопії: при деструктивному апендициті - у 10 (13,51\%), перфоративній виразці шлунка та дванадцятипалої кишки - у 6 (12,5\%), деструктивному холециститі - у 9 (13,04\%), спайковій кишковій непрохідності - у 13 (19,12\%) з 68, защемлених та ускладнених грижах - у 14 (17,28\%) з 81 обстежених хворих. Під час релапаротомії неспроможність стінки кишки та кишкових швів встановлено в 11332 пацієнтів, накладено ілеостому в 7, а цекостому - в 1 хворого. У контрольній групі померло 8 (6,84\%) хворих на тлі продовжуваного перитоніту, тромбозу мезентеріальних судин та поліорганної недостатності й супутніх хвороб, а в досліджуваній - 4 (3,96\%) хворі.

Висновки. Хірургічне лікування $є$ індивідуальним залежно від недуги. Так, при деструктивному апендициті 374 (38,74\%) осіб лапаротомію виконано 42 (21,99\%), лапароскопію - 32 (16,75\%), а 12 (6,28\%) пацієнтам - із конверсією; при перфоративній виразці шлунка та дванадцятипалої кишки проведено відкриту лапаротомію у 48 (25,13\%); при холециститі 369 (36,13\%) хворих лапаротомію проведено 48 (25,13\%), а лапароскопію - 21 (11,00\%) особі. Застосування візуалізаційних і лікувальних технологій - допплерографії, гідроструменевого скальпеля та лапароскопії у 64 (33,51\%) - дало змогу отримати кращі близькі і віддалені результати з урахуванням якості життя та знизити рівень післяопераційної летальності з 6,84\% до 3,96\% (середній показник - 5,5\%). 
Дослідження виконано відповідно до принципів Гельсінської декларації. Протокол дослідження ухвалено Локальним етичним комітетом зазначених установ. На проведення досліджень отримано інформовану згоду пацієнтів.

Автори заявляють про відсутність конфлікту інтересів.

Ключові слова: деструктивний апендицит, холецистит, перфоративна виразка шлунка та дванадцятипалої кишки, спайкова непрохідність, защемлені грижі, діагностика та лікування.

\section{Evolution of diagnosis and surgical treatment of intra-abdominal infiltrates, abscesses of primary and postoperative origin in patients V.V. Skyba ${ }^{1,3,4}$, V.F. Rybalchenko ${ }^{2,3}$, A.V. Ivanko ${ }^{1,3,4}$, R.M. Borys ${ }^{3}$, Dar Yasinya Akhmed ${ }^{3}$, V.V. Lysytsa ${ }^{3,4}$ \\ ${ }^{1}$ A.A. Bogomolets National Medical University, Kyiv, Ukraine}

${ }^{2}$ Shupyk National Healthcare University of Ukraine, Kyiv

${ }^{3}$ Kyiv medical university, Ukraine

${ }^{4}$ Health Medical Center Hospital, Kyiv, Ukraine

Purpose - to improve the results of surgical treatment of patients with intra-abdominal infiltrates and abscesses through the introduction of the latest imaging methods and surgical technologies.

Materials and methods. In the clinic of the Department of Surgical Diseases No 1, on the basis of the Surgery Center of the Kyiv City Clinical Hospital No. 1 from 2006 to 2019218 patients with primary and secondary intra-abdominal infiltrates, abscesses and fluid formations were treated. The patients' age ranged from 16 to 85 years. There were 107 (49.08\%) male patients, 111 (50.92\%) female patients. Depending on the time of hospitalization (by years), the patients were divided into two groups: the control group (CG) (2006-2012) 117 (53.67\%) patients and the study group (SG) (2013-2019) 101 (46.33\%) patients. The SG used the latest imaging technologies and improved methods of surgical treatment.

Results. The patients were divided into two groups: primary in 191 (87.61\%) and secondary postoperative infiltrates and abscesses in 27 (12.39\%). The causes of primary infiltrates and abscesses were: complicated forms of appendicitis in 74 (33.94\%), perforated stomach and duodenal ulcer in 48 (22.02\%), complicated forms of cholecystitis in 69 (31.65\%). Postoperative infiltrates and abscesses were observed in 27 (12.39\%) patients who underwent urgent surgery: adgeolysis of adhesive ileus in $14(6.42 \%)$ and complicated hernias of various localization in $13(5.97 \%)$. Postoperative complications were diagnosed in $43(19.72 \%)$ patients, of whom $34(15.59 \%)$ from the surgical wound and $29(15.18 \%)$ of the abdominal cavity, who required relaparotomy or laparoscopy, with destructive appendicitis in 10 (13.51\%), perforated gastric ulcer and 12 duodenal ulcer in $6(12.5 \%)$, destructive cholecystitis in 9 (13.04\%), adhesive intestinal obstruction in 13 (19.12\%) and with strangulated and complicated hernias in 14 (17.28\%) of the examined patients. During relaparotomy, incompetence of the intestinal wall and intestinal sutures was established in 11 out of 32 patients, an ileostomy was imposed in 7, and cecostomy in 1 patient. Actually, in the control group, $8(6.84 \%)$ patients died on the background of ongoing peritonitis, thrombosis of mesenteric vessels and multiple organ failure and concomitant ailments and in the study group 4 (3.96\%) patients died.

Conclusions. Surgical treatment is individualized depending on the disease, so with destructive appendicitis from 74 (38.74\%) laparotomic in 42 (21.99\%), laparoscopic in $32(16.75 \%)$, and in $12(6.28 \%)$ with conversion; perforated gastric ulcer and duodenal ulcer in 48 (25.13\%) open laparotomy; with cholecystitis of 69 (36.13\%) patients, $48(25.13 \%)$ had laparotomy and $21(11.00 \%)$ had laparoscopic examination. The use of the latest imaging and treatment technologies: Doppler ultrasonography, hydrojet scalpel and laparoscopy in $64(33.51 \%)$, allowed to have better near and long-term results and to reduce postoperative mortality from $6.84 \%$ to $3.96 \%$, with an average of $5.5 \%$.

The research was carried out in accordance with the principles of the Helsinki declaration. The study protocol was approved by the Local Ethics Committee of these Institutes. The informed consent of the patient was obtained for conducting the studies.

The authors declare no conflicts of interests.

Key words: destructive appendicitis, cholecystitis, perforated gastric ulcer and 12-duodenal ulcer, adhesive leakage, strangulated hernias, diagnosis and treatment.

\section{Эволюция диагностики и хирургического лечения больных интраабдоминальными инфильтратами и абсцессами первичного и послеоперационного происхождения}

В.В. Скиба ${ }^{1,3,4}$, В.Ф. Рыбальченко ${ }^{2,3}$, А.В. Иванько ${ }^{1,3,4}$, Р.Н. Борис

${ }^{1}$ Национальный медицинский университет имени А.А. Богомольца, г. Киев, Украина

${ }^{2}$ Национальный университет здравоохранения Украины имени П.Л. Шупика, г. Киев

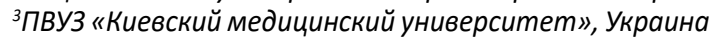

${ }^{4}$ КНП «Киевская городская клиническая больница № 1», Украина

Цель - улучшить результаты хирургического лечения больных с интраабдоминальными инфильтратами и абсцессами за счет внедрения новейших методов визуализации и хирургических технологий.

Материалы и методы. В клинике кафедры хирургических болезней № 1 на базе центра хирургии Киевской городской клинической больницы № 1 в период 2006-2019 гг. проходили лечение 218 пациентов с первичными и вторичными интраабдоминальными инфильтратами и абсцессами. Возраст пациентов составил от 16 до 85 лет. Среди больных было 107 (49,08\%) мужчин и 111 (50,92\%) женщин. В зависимости от времени госпитализации (по годам) больные поделены на две группы: контрольная группа (2006-2012 гг.) - 117 (53,67\%) лиц, исследуемая группа (20132019 гг.) - 101 (46,33\%) больной. В исследуемой группе использованы информативные визуализационные технологии и усовершенствованные методики хирургического лечения.

Результаты. Больные поделены на две группы в зависимости от развития болезни и проведения лечения: первичные инфильтраты и абсцессы у 191 (87,61\%), вторичные послеоперационные - у 27 (12,39\%). Причинами возникновения первичных инфильтратов и абсцессов были: осложненные формы аппендицита - у 74 (33,94\%), перфоративная язва желудка и двенадцатиперстной кишки -у 48 (22,02\%), осложненные формы холецистита - у 69 (31,65\%) лиц. Послеоперационные инфильтраты и абсцессы наблюдались у 27 (12,39\%) больных, перенесших ургентные операции: адгеолизис спаечной непроходимости - 14 (6,42\%), осложненные грыжи различной локализации - 13 (5,97\%). Послеоперационные 
осложнения диагностировались у 43 (19,72\%) больных, из них со стороны операционной раны -у 34 (15,59\%), брюшной полости - у 29 (15,18\%), требовавшие проведения релапаротомии или лапароскопии, при деструктивном аппендиците - у 10 (13,51\%), перфоративной язве желудка и двенадцатиперстной кишки - у 6 (12,5\%), деструктивном холецистите - у 9 (13,04\%), спаечной кишечной непроходимости - у 13 (19,12\%) с 68, при ущемленных и осложненных грыжах - у $14(17,28 \%)$ с 81 обследованных больных. Во время релапаротомии несостоятельность стенки кишки и кишечных швов установлена у 11 из 32 пациентов, наложена илеостома - у 7, а цекостома - у 1 больного. В контрольной группе умерло 8 (6,84\%) больных на фоне продолжающегося перитонита, тромбоза мезентериальных сосудов и полиорганной недостаточности и сопутствующие недугов, а в исследовательской группе - 4 (3,96\%) больных.

Выводы. Хирургическое лечение является индивидуальным в зависимости от заболевания. Так, при деструктивном аппендиците из 74 (38,74\%) больных лапаротомия проведена 42 (21,99\%), лапароскопия - 32 (16,75\%), а 12 (6,28\%) пациентам - с конверсией; при перфоративной язве желудка и двенадцатиперстной кишки выполнена открытая лапаротомия 48 (25,13\%); при холецистите из 69 (36,13\%) больных лапаротомия проведена $48(25,13 \%)$, а лапароскопия - 21 (11,00\%) больному. Использование визуализационных и лечебных технологий - допплерографии, гидроструйного скальпеля и лапароскопии у 64 (33,51\%) больных - позволило получить лучшие близкие и отдаленные результаты с учетом качества жизни и снизить уровень послеоперационной летальности с 6,84\% до 3,96\% (средний показатель -5,5\%).

Исследование выполнено в соответствии с принципами Хельсинской декларации. Протокол исследования утвержден Локальным этическим комитетом указанных в работе учреждений. На проведение исследований получено информированное согласие пациентов.

Авторы заявляют об отсутствии конфликта интересов.

Ключевые слова: деструктивный аппендицит, холецистит, перфоративная язва желудка и двенадцатиперстной кишки, спаечная непроходимость, ущемленные грыжи, диагностика и лечение.

Інтраабдомінальні інфільтрати й абсцеси становлять від $2 \%$ до 29,6\% в ургентній хірургії та не мають тенденції до зниження. Вони є однією з найактуальніших проблем, особливо в осіб працездатного віку, а це обумовлює соціальну значущість проблеми. Поміж тим, соціально-економічні чинники зумовлюють пізнє звернення по допомогу, а це, своєю чергою, призводить до формування абсцесів й інфільтратів черевної порожнини у хворих від 20,5\% до 25\% [4,7-10,15,17].

За даними П.Д. Фоміна і співавт. (2018), в Україні пізніше 24 год від початку захворювання госпіталізують пацієнтів: із деструктивним апендицитом (ДА) - 20,9\% (при післяопераційній летальності $0,15 \%)$; із гострим холециститом - 38,1-39,2\% (при післяопераційній летальності в середньому 16,3$19,7 \%)$; із перфоративною гастродуоденальною виразкою - 12,5\% (при післяопераційній летальності $13,73 \%)$; із гострою непрохідністю кишечника - 5\%, а серед гострих хірургічних захворювань черевної порожнини грижі живота у $3-4 \%$ усього населення з частотою ускладнень - утисків у 3-27\% хворих [4]. За літературними даними, післяопераційні абсцеси розвиваються в $0,8-2 \%$ оперованих хворих при летальності 10,5-26\%. При цьому внутрішньочеревні абсцеси й інфільтрати посідають друге місце серед причин релапаротомії в ранньому післяопераційному періоді $[4,7,10]$. Поміж тим, післяопераційні ускладнення $є$ значною проблемою як прогнозування перебігу, так і хірургічного лікування невідкладних станів органів черевної порожнини. За даними Olanrewaju Samuel Balogun та співавт. (2019), їх кількість становить $28,5 \%$ із такими ускладненнями, як нагноєння операційної рани $(18,6 \%, 3$ розбіжністю у 15,2\%) й інтраабдомінальні абсцеси (13,5\%) [2]. Так, Varut Lohsiriwat та співавт. (2009) вказує на те, що при перфоративній виразковій хворобі частота ускладнень дорівнює 30\% [6]. F. Ausania та співавт. (2015) зазначає, що перфорація жовчного міхура становить 2-11\% із показником захворюваності 57,7\% [1].

Таким чином, вищезазначене підкреслює необхідність подальшого вивчення цієї патології як із метою прогнозування перебігу хвороби, так і адекватного хірургічного лікування для досягнення зменшення кількості післяопераційних ускладнень і летальності.

Мета дослідження - поліпшити результати хірургічного лікування хворих із первинними та післяопераційними інтраабдомінальними інфільтратами й абсцесами за рахунок впровадження високоінформативних новітніх методів візуалізації та хірургічних технологій.

\section{Матеріали та методи дослідження}

У клініці кафедри хірургічних хвороб № 1, на базі центру хірургії Київської міської клінічної лікарні № 1 у період 2006-2019 рр. перебували на лікуванні 218 пацієнтів із первинними і вторинними інтраабдомінальними інфільтратами, абсцесами і рідинними утвореннями. Вік хворих становив від 16 років до 85 років. Серед пацієнтів було 107 (49,08\%) чоловіків і 111 (50,92\%) жінок. До дослідження залучили хворих, які страждали від пухких інфільтратів, абсцесів і рідинних утворень. До дослідження не залучені пацієнти зі щільними інфільтратами, оскільки відмінна тактика лікування. Залежно від часу шпиталізації (по роках) хворих поділили на дві групи: контрольна група (2006-2012 pp.) - 117 (53,67\%) осіб; досліджувана група (2013-2019рр.) 101 (46,33\%) пацієнт. Причинами поділу на групи $€$ використання в досліджуваній групі новітніх інноваційних технологій для діагностики: комп’ютерна томографія (КТ), магнітно-резонансна томографія (MPТ), ультразвукове дослідження (УЗД) + кольо- 
Оригінальні дослідження. Абдомінальна хірургія

Таблиця 1

Нозологічна характеристика хворих на інтраабдомінальні ускладнення по групах дослідження

\begin{tabular}{|c|c|c|c|c|c|c|c|c|c|c|c|c|c|c|c|c|c|}
\hline \multicolumn{18}{|c|}{ У 218 хворих хвороба ускладнилася інфільтратом і абсцесом } \\
\hline \multicolumn{12}{|c|}{ Первинні інтраабдомінальні ускладнення } & \multicolumn{6}{|c|}{ Вторинні } \\
\hline \multicolumn{4}{|c|}{ ДА } & \multicolumn{4}{|c|}{\begin{tabular}{|r|r}
$\Pi B$ \\
\end{tabular}} & \multicolumn{4}{|c|}{ Дх } & \multicolumn{6}{|c|}{ уло } \\
\hline \multicolumn{18}{|c|}{ Відсотки (\%) у цілому від загальної кількості 218 хворих } \\
\hline \multicolumn{4}{|c|}{$\begin{array}{c}74(33,95 \%) \\
4-38, \%-36\end{array}$} & \multicolumn{4}{|c|}{$\begin{array}{c}48(22,02 \%) \\
4-37, \nVdash-11\end{array}$} & \multicolumn{4}{|c|}{$\begin{array}{c}69(31,65 \%) \\
4-21, \nVdash-48 \\
\end{array}$} & \multicolumn{6}{|c|}{$\begin{array}{c}27(12,38 \%) \\
4-11, \nVdash-16\end{array}$} \\
\hline \multicolumn{18}{|c|}{ Відсотки (\%) у кожній групі, індивідуально за 100,0\% } \\
\hline \multicolumn{4}{|c|}{ ДА 74 (100,0\%) } & \multicolumn{4}{|c|}{$\Pi B-48(100,0 \%)$} & \multicolumn{4}{|c|}{ ДХ- $69(100,0 \%)$} & \multicolumn{6}{|c|}{ УлО - $27(100,0 \%)$} \\
\hline \multicolumn{2}{|c|}{$\begin{array}{c}\mathrm{K} \Gamma- \\
39(52,70 \%)\end{array}$} & \multicolumn{2}{|c|}{$\begin{array}{c}\text { ДГ- } \\
35(47,30 \%)\end{array}$} & \multicolumn{2}{|c|}{$\begin{array}{c}\mathrm{K} \Gamma- \\
26(54,17 \%)\end{array}$} & \multicolumn{2}{|c|}{$\begin{array}{c}\text { ДГ- } \\
22(45,83 \%) \\
\end{array}$} & \multicolumn{2}{|c|}{$\begin{array}{c}\mathrm{K} \Gamma- \\
37(53,62 \%)\end{array}$} & \multicolumn{2}{|c|}{$\begin{array}{c}\text { ДГ- } \\
32(46,38 \%)\end{array}$} & \multicolumn{3}{|c|}{ КГ- $15(55,55 \%)$} & \multicolumn{3}{|c|}{ ДГ- $12(44,45 \%)$} \\
\hline A & 1 & A & $\mathrm{I}$ & A & 1 & A & 1 & A & $\mathrm{I}$ & A & 1 & A & Py & 1 & A & Py & 1 \\
\hline 32 & 7 & 16 & 19 & 8 & 18 & 20 & 2 & 35 & 2 & 24 & 8 & 3 & 8 & 4 & - & 8 & 4 \\
\hline \multicolumn{18}{|c|}{ Повторні операції з причини післяопераційних інтраабдомінальних ускладнень } \\
\hline 4 & 3 & 2 & 1 & 3 & 1 & 1 & $1 \quad 1$ & 4 & \begin{tabular}{l|l}
2 & \\
\end{tabular} & 2 & \begin{tabular}{l|l}
1 & \\
\end{tabular} & 3 & 8 & 4 & - & 8 & 4 \\
\hline
\end{tabular}

Примітки: ДА - деструктивний апендицит, ДХ - деструктивний холецистит, ПВ - перфоративна виразка шлунка та дванадцятипалої кишки, УлО - ургентні лапаротомні операції (спайкова непрохідність та ускладнені грижі різної локалізації), Кг - контрольна група (за 2006-2012 рр.), Дг - досліджувана група (за 2013-2019 рр.), А - абсцес, І -інфільтрат, Ру - рідинне утворення.

рове дуплексне картування + еластографія, термометрія), а також новітніх загальновизнаних та вдосконалених методик хірургічного лікування: лапароскопія та гідроструменеві технології розділення тканин. У подальшому всіх хворих контрольної і досліджуваної груп поділили на 4 підгрупи залежно від чинників захворювання. Поміж тим, усі 4 групи хворих - це особи, які шпиталізовані в ургентному порядку та мали оперативне лікування після дообстеження і передопераційної підготовки. Під час госпіталізації провели загальноклінічне і біохімічне обстеження крові та сечі у всіх хворих. Рентгенологічне дослідження (оглядову рентгенографію органів черевної порожнини у вертикальному та поліпозиційному положенні) провели 129 (59,19\%) хворим, КТ - 49 (22,48\%); УЗД органів черевної порожнини - 105 (48,16\%) хворим, а дослідження стану кровотоку утворення - кольорове дуплексне картування - 43 (19,72\%), еластографію $43(19,72 \%)$ особам. Ректальне і бімануальне дослідження виконали 127 (58,26\%) пацієнтам; термометрію передньої черевної стінки - $76(34,86 \%)$ хворим.

Дослідження виконали відповідно до принципів Гельсінської декларації. Протокол дослідження ухвалили Локальним етичним комітетом зазначених установ. На проведення досліджень отримали інформовану згоду пацієнтів.

\section{Результати дослідження та їх обговорення}

Для вирішення мети дослідження та залежно від розвитку недуги й проведення лікування хворих поділили на дві групи: первинні - доопераційні інфільтрати й абсцеси - у 191 (87,61\%) осіб; вторинні після- операційні інфільтрати й абсцеси - у 27 (12,39\%) пацієнтів (це на початку відбору клінічного матеріалу). Причинами виникнення первинних інфільтративних й абсцедуючих утворень черевної порожнини були: ускладнені форми апендициту - у 74 (33,94\%), перфоративна виразка (ПВ) шлунка та дванадцятипалої кишки - у 48 (22,02\%), ускладнені форми холециститу - у 69 (31,65\%). До основних післяопераційних ускладнень у 27 (12,39\%) випадках, що слугували розвитку вторинних інфільтративних й абсцедуючих утворень, належали: адгеолізис після хірургічного лікування спайкової непрохідності у 14 (6,42\%), великих розмірів грижі різної локалізації з клінікою непрохідності кишечника на тлі защемлення - у 13 (5,97\%). Поміж тим, із 191 (87,61\%) хворого з первинними ускладненнями в післяопераційному періоді встановили післяопераційні ускладнення у 25 (13,08\%). Таким чином, післяопераційні ускладнення внаслідок видалення деструктивного та ускладненого апендициту виявили у $10(13,51 \%)$ із 74 осіб, ПВ шлунка та дванадцятипалої кишки - у $6(12,5 \%)$ з 48, деструктивного ускладненого холециститу - у 9 (13,04\%) з 69 хворих. Поділ хворих по нозологічних групах дослідження і підгрупах наведено в таблиці 1.3 урахуванням стадійності перебігу післяопераційного періоду, поміж розвитком інфільтратів й абсцесів, групу з рідинними утвореннями виділили у 18 хворих, які потребували індивідуального вибору хірургічної тактики від пункційного методу до релапароскопії або релапаротомії. Як видно з таблиці, групи дослідження за кількістю пацієнтів були тотожними, що дало змогу проводити порівняння. 


\section{Анамнестичні дані}

Дослідження ретроспективного архівного матеріалу та поточного вивчення скарг і анамнезу перебігу поточної хвороби дало змогу встановити захворювання інших органів і систем, а також тривалість перебігу супутніх захворювань. Під час огляду пацієнта в приймальному відділенні, окрім скарг щодо основної хвороби, визначали масу тіла хворого, що $\epsilon$ стандартом при госпіталізації хворих. 3 метою дослідження ваги використовували індекс маси тіла (IMT). Результати дослідження показали таке: у $87(39,91 \%)$ хворих маса тіла була в межах норми, у

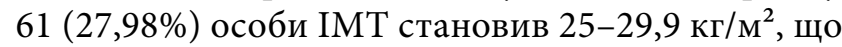
вказувало на передожиріння, при якому виражені симптоми ожиріння були відсутніми. Поміж тим, у

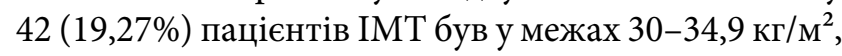
що вказувало на І ступінь ожиріння, у 20 (9,17\%) хворих - у межах 35-39,9 кг/м², що вказувало на II ступінь ожиріння, у 8 (3,67\%) осіб - понад 40 кг/ $\mathrm{m}^{2}$, що вказувало на III ступінь ожиріння. Таким чином, у 148 (67,89\%) осіб показники IMT не вказували на ожиріння, а в $70(32,11 \%)$ пацієнтів було порушення ваги різного ступеня. Наступним, на що звернули увагу в приймальному відділенні, було те, що 126 (57,80\%) хворих носили окуляри. Такі дані свідчили про порушення зору, з яких 32 (14,68\%) хворі носили окуляри з підліткового віку. Операції з приводу катаракти перенесли 26 (11,93\%) пацієнтів. Хвороби серцево-судинної системи та порушення тиску, за даними історій хвороб та анамнезу, мали $123(56,42 \%)$ хворі, із них інфаркт міокарда 32 (14,68\%), стентування перенесли 27 (12,38\%) осіб, ішемічну хвороба серця - $49(22,48 \%)$ пацієнтів. Цукровий діабет (ЦД) встановили у 38 (17,43\%) пацієнтів, які мали показники цукру крові понад 15 ммоль/л. Захворювання опорно-рухового апарату виявили у $27(12,38 \%)$ хворих, із них $4(1,83 \%)$ особи перенесли протезування кульшових суглобів. Дослідженнями встановлено, що 48 (22,02\%) хворих страждали від плоскостопості різного ступеня.

Усі хворі мали різного ступеня абдомінальний больовий синдром, який різнився локалізацією, іррадіацією залежно від вказаного захворювання. На рисунку 1 схематично наведено локалізацію абдомінального болю: а - при ДА, 6 - при ПВ шлунка, в при ДХ.

Фізикальне обстеження передньої черевної стінки провели у всіх хворих. Збільшення живота в розмірах за рахунок жирової клітковини встановили у 53 (24,31\%), помірне та рівномірне здуття живота - у $72(33,03 \%)$, виражене здуття - у 47 (21,56\%), а асиметричний живіт - 46 (21,10\%) хворих. Рубці на пе- редній черевній стінці встановили у 39 (17,89\%) пацієнтів. Судинний малюнок був вираженим у 63 (28,90\%) хворих. Пальпація живота поверхнева була болючою у всіх хворих, а глибока пальпація мала свої особливості, детальніше описані в кожній підгрупі. Термометрію передньої черевної стінки виміряли $76(34,86 \%)$ хворим досліджуваної групи.

Клініко-лабораторне дослідження передбачало загальний аналіз крові та його біохімічне дослідження, а також загальний аналіз сечі. Досліджували показники червоної та білої крові (лейкоцити (L) і паличкоядерні (п/я) клітини). У групах наведено результати лабораторного дослідження та їх зміни залежно від ступеня запального процесу в черевній порожнині.

Діагностика ускладненого перебігу апендициту в контрольній групі хворих грунтувалася на даних анамнезу, клініко-лабораторних і даних пальпації.

У контрольній групі хворих основними візуалізаційними методами обстеження пацієнтів була оглядова рентгенографія черевної та грудної порожнини, яку виконали хворим із клінікою ПВ шлунка та дванадцятипалої кишки, а також хворим із підозрою на непрохідність кишечника на тлі запального процесу. УЗД черевної порожнини в цій групі провели 12 хворим. Це був початок впровадження методу в ургентній хірургії. Аналіз ретроспективних даних у 26 (13,61\%) хворих на ПВ шлунка та дванадцятипалої кишки показав, що у $6(23,07 \%)$ із 26 не встановили вільного повітря в черевній порожнині, а тільки за результатами фіброгастродуоденоскопії (ФЕГДС) виявили перфорацію та вільне повітря в черевній порожнині, що підтвердили повторним дослідженням. Рентгенологічне дослідження провели у $14(18,42 \%)$ з 76 хворих, які мали клініку непрохідності кишечника, на тлі запального процесу, причиною якого був деструктивний апендицит - ДА (у 5 (12,82\%) з 39 осіб) та деструктивний холецистит - ДХ (у 9 (24,32\%) з 37 пацієнтів). Таким чином, у контрольній групі хворих основним постулатом, на якому грунтувався діагноз, був власне досвід хірурга за результатами анамнезу та клінічного і лабораторного обстеження, що в подальшому підтвердили інтраопераційно.

У досліджуваній групі хворих у приймальному відділенні проаналізували анамнез, а під час огляду виміряли нашкірну температуру передньої черевної стінки у $48(53,93 \%)$ з 89 хворих, з них у $39(81,25 \%)$ з 48 вона була підвищеною на $2-3^{\circ} \mathrm{C}(32(91,42 \%) 3$ 35 хворих на ДА, 7 (21,87\%) із 32 хворих на ДХ), а у $9(18,75 \%)$ з 48 з причини збільшеного живота та вираженого жирового шару (складки жирового шару) 

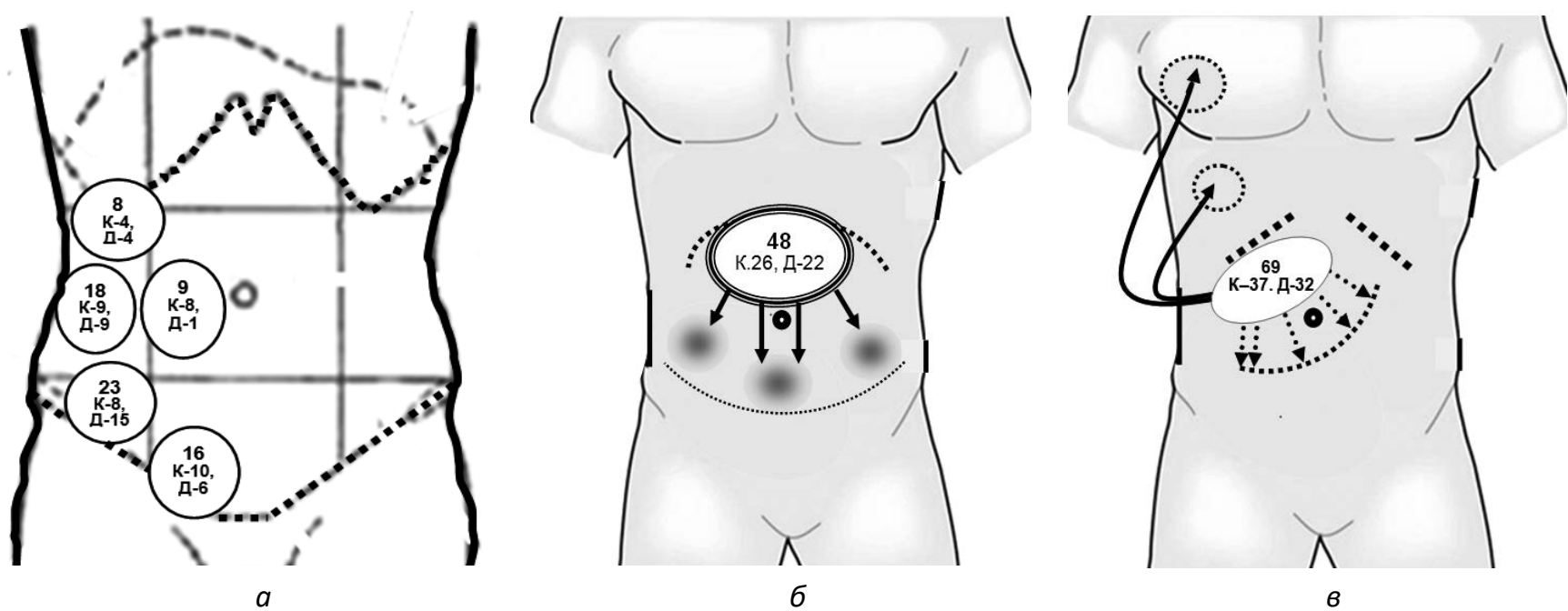

Рис. Локалізація больового синдрому: а - при деструктивному апендициті, б - перфоративній виразці шлунка, в - деструктивному холециститі

метод не був інформативним. У подальшому на основі маршруту пацієнта провели дослідження крові та сечі, рентгенологічне та УЗД. У результаті УЗД черевної порожнини встановили як прямі, так і непрямі ознаки запального процесу в черевній порожнині та його наслідки. Поміж тим, інформативність візуалізації залежала від кількості повітря в просвіті кишечника. УЗД провели 81 (91,01\%) хворому із 89 пацієнтів, з яких при ДА - 35 (100\%) із 35, при ДХ - $32(100 \%)$ із 32, при ПВ - $14(63,63 \%)$ iз 22. Результати дослідження при ДА показали, що ДА встановлено у 68 із 72, з яких апендикулярний абсцес - у 15 (93,75\%) із 16, а апендикулярний інфільтрат - у $18(94,73 \%)$ із 19, а також різний ступінь регіонарного мезаденіту та вмісту рідини в черевній порожнині. За даними візуалізації як ДА, так і апендикулярних абсцесів й інфільтратів встановили локалізацію (розташування) апендикулярного паростка, з яких типову локалізацію - у 22 (62,85\%) із 35, медіальне - у $6(17,14 \%)$ із 35 , підпечінкове у $7(20,0 \%)$ із 35. Виявили непрямі ознаки УЗД при ДА: вільна рідина як по правому фланку у $32(91,42 \%)$ iз 35 із включеннями, а також у ділянці кореня брижі кишечника - у $8(22,85 \%)$ із 35 , набряк стінки тонкого кишечника - у 29 (82,85\%) iз 35 , порушення (зменшення) перистальтики кишечника - у 28 (80,0\%) із 35, локальна прискорена перистальтика - у $3(8,57 \%)$ із 35, збільшення та набряк брижових й ілеоцекальних лімфатичних вузлів у всіх 35 хворих. Допплерографічне дослідження показало збільшення кровотоку в інфільтративних тканинах великого чіпця та стінках кишки у $19(54,28 \%)$ iз 35 хворих. Натомість, за наявності абсцесу в центрі візуалізували рідинне утворення з відсутністю кровотоку. УЗД жовчного міхура провели $32(100 \%)$ пацієнтам із 32 хворих досліджуваної групи. За результатами УЗД встановили: наявність конкрементів у просвіті - у $12(37,5 \%)$ із 32 , набряк стінки жовчного міхура понад 5 мм у $30(93,75 \%)$ із 32 , наявність газу у стінці у $21(65,62 \%)$ із 32, позитивний ультрасонографічний симптом Мерфі - у всіх пацієнтів, збільшення розмірів жовчного міхура - у $31(96,87 \%)$ із 32 , зміни у просвіті жовчного міхура (осад) - у $15(46,87 \%)$ iз 32 , скупчення рідини навколо жовчного міхура у $24(75,0 \%)$ із 32 та інфільтративний перивезикальний процес - у 8 (25,0\%) із 32. Кольорове дуплексне картування провели 13 (40,62\%) хворим із 32 пацієнтів і встановили порушення кровообігу в стінці жовчного міхура - від зменшення ділянками до повної відсутності кровообігу (ділянки деструкції), а також посилення кровообігу у великому чіпці, який обгортав жовчний міхур із перивезикальною рідиною та був інфільтративно зміненим. УЗД провели $11(50,0 \%)$ особам із 22 хворих на ПВ, яке було інформативними у $5(22,72 \%)$ із 22 із візуалізацією вільної рідини в порожнині малого тазу та по фланках, але у $6(27,27 \%)$ із 22 пацієнтів із причини великої кількості повітря не вдалося візуалізувати чіткі межі інфільтративного утворення.

Рентгенологічне дослідження органів черевної порожнини хворих на ДА провели з причини підозри на непрохідність кишечника (вертикальна позиція) у 10 (28,57\%) із 35 та встановили парез кишечника на тлі запального процесу і прояви рідини в просвіті тонкого кишечника у 8 (80,0\%) із 10 пацієнтів. Оглядову рентгенографію виконали 5 (15,62\%) особам із 32 хворих, що страждали від ДХ, з яких 
у всіх 5 хворих візуалізували конкременти. Оглядову рентгенографію виконали 22 хворим, що страждали від ПВ шлунка та дванадцятипалої кишки, з яких вільне повітря різної кількості під куполами діафрагми встановили у $17(77,27 \%)$ із 22 хворих. 3 метою верифікації захворювання та прискіпливої візуалізації патологічного процесу в черевній порожнині провели КТ 16 хворим, із яких 5 особам із ПВ з причини неінформативності (відсутності повітря) оглядової рентгенографії, та 11 - з метою диференційної діагностики візуалізації підпечінкового ДА. За даними КТ візуалізували ПВ препілоричного відділу, а також підпечінкове розташування ДА. Отримані результати клініко-лабораторного та інструментального обстеження в досліджуваній групі доповнили відповідно підгрупи архівними даними в контрольній групі.

До першої групи з ускладненими формами ДА увійшли 74 (100,0\%) хворі з первинними пухкими інфільтратами й абсцесами апендикулярного походження: у контрольній групі - 39 (17,88\%) пацієнтів, досліджуваній - 35 (16,06\%) осіб. Скарги хворих на виражений абдомінальний біль висловлювали всі хворі, із яких на нестерпний - $26(35,14 \%)$ осіб, пульсуючий - $48(64,86 \%)$ пацієнтів. Усі хворі приймали вимушене положення на правому боці, яке сприяло полегшенню стану. Порушення апетиту мали всі хворі, з яких нудоту мали $16(21,62 \%)$ осіб, одноразове блювання - $32(43,24 \%)$ пацієнти, багаторазове - $26(35,14 \%)$ хворих. Порушення частоти та глибини дихання виявили у 58 (78,38\%) хворих. Загальна температура мала фебрильний характер у всіх хворих, із яких в $11(14,86 \%)$ пацієнтів $\mathrm{t}=37,5 \pm 0,76^{\circ} \mathrm{C}$, y $15(20,27 \%)$ осі6 $\mathrm{t}=38,7 \pm 0,52^{\circ} \mathrm{C}$, у $48(64,97 \%)$ хворих $\mathrm{t}=39,5 \pm 0,41^{\circ} \mathrm{C}$. Термометрію нашкірної температури передньої черевної стінки виконали безконтактним інфрачервоним термометром та порівняли з аксилярною у 30 (40,54\%) хворих, що дало змогу констатувати локальне підвищення температури (локалізації розташування апендикса) на $2,05 \pm 0,11^{\circ} \mathrm{C}$ порівняно з іншими зонами передньої черевної стінки та аксилярною температурою. Пальпація черевної порожнини дозволила встановити інфільтративні утворення в 5 зонах розмірами $12,52 \pm 2,34$ см на $15,12 \pm 1,89$ см із локально вираженою болючістю в центрі у $48(64,86 \%)$ та менш вираженим болем, але більшою щільністю у $26(35,14 \%)$ осіб, що схематично наведено на рисунку. Симптоми подразнення очеревини (перитоніальні симптоми) були позитивними у всіх хворих. Подальшими дослідженнями встановлено, що зміна інтенсивності болю пов'язана з утвореним абсцесом і м’яким інфільтратом. Під час УЗД органів черевної порожнини виявили як основні ознаки інфільтрату у $26(35,14 \%)$ чи абсцесу у $48(64,86 \%)$ хворих, а також характер і поширення інфільтративного процесу. В досліджуваній групі провели: УЗД + кольорове дуплексне картування 12 (16,22\%) особам, а компресійну та зсувну еластографію - 21 (28,38\%) пацієнтові. Рентгенологічне дослідження органів черевної порожнини з причини підозри на непрохідність кишечника (вертикальна позиція) виконали 23 (31,08\%) особам, з яких у контрольній групі 15 (20,27\%), досліджуваній групі - 8 (10,81\%). Парез кишечника на тлі запального процесу мав прояв рівнів рідини у просвіті тонкого кишечника у $18(24,32 \%)$ хворих. Ректальне дослідження було інформативним у $57(91,93 \%)$ із 62, із яких у контрольній групі - у $28(37,84 \%)$, у досліджуваній у $34(45,94 \%)$ хворих. у загальному аналізі крові показники червоної крові у $62(83,78 \%)$ мали такі дані: $\mathrm{Hb}=97 \pm 3,14$ г/л, $\mathrm{Er}=2,8 \pm 0,75 \times 10^{12}$, а у $12(16,22 \%)$ пацієнтів: $\mathrm{Hb}=86 \pm 2,12$ г/л, $\mathrm{Er}=2,6 \pm 1,14 \times 10^{12}$. Зміни лейкоцитів різнилися залежно від тривалості й гостроти гнійно-запального процесу. Так, у $36(48,64 \%)$ хворих $\mathrm{L}=18,5 \pm 2,11 \times 10^{9}$, у $26(35,14 \%)$ осіб $\mathrm{L}=21,2 \pm 2,23 \times 10^{9}$, у $12(16,22 \%)$ пацієнтів $\mathrm{L}=32,2 \pm 3,24 \times 10^{9}$, зі збільшенням сегментоядерних лейкоцитів відповідно від $68 \pm 1,21 \%$ до $79 \pm 1,11 \%$, а також нейтрофілів (паличкоядерних) від $25 \pm 2,51 \%$ до $38 \pm 2,13 \%$. Хірургічне лікування хворих з ДА різнилося по групах. Так, хірургічний доступ у $42(56,76 \%)$ хворих був лапаротомний i пов'язаний з локалізацією інфільтративно абсцедуючого утворення, з яких в $11(14,86 \%)$ - серединна лапаротомія, у 31 (41,89\%) - правобічна трансректальна. Лапароскопічний метод застосували у $32(43,24 \%)$ хворих, з яких у 12 (16,22\%) осіб у зв'язку з технічними труднощами провели конверсію. Причинами конверсії були: початок впровадження лапароскопічних технологій - у 4 (5,40\%) хворих, а також нетипове розташування інфільтративно-абсдедуючого утворення: підпечінкове у 2 (2,70\%), заочеревинне - у 5 (6,76\%), у порожнині малого таза - в 1 (1,35\%). Розділення інфільтративного утворення провели у контрольній групі механічним шляхом із застосуванням монополярної коагуляції та прошивання тканин 39 (52,70\%) особам, а у досліджуваній групі - за допомогою гідроструменевого скальпеля 15 (20,27\%) хворим. у досліджуваній групі застосували апарат «LigaSureTM» у 35 (47,30\%) хворих, з яких у 15 (20,27\%) - під час лапаротомії, у $20(27,03 \%)$ - під час лапароскопії. Брижу апендикса виділили та наклали шви, з яких 
у 39 (52,70\%) - один шов, у 25 (33,78\%) - два шви, а у 35 (47,30\%) осіб брижейки апендикса і судини обробили біполярною коагуляцією. Куксу перев'язаного апендикса погрузили під кисетний i $\mathrm{Z}$-подібний шов у 38 (51,35\%), а у 16 (21,62\%) осіб через виражений запальний процес на куполі наклали окремі шви в кількості від 6 до 8. Під час лапароскопії, яку провели 20 (27,03\%) хворим, на основу паростка наклали механічний і Z-подібний шов 5 (6,76\%) пацієнтам. Санацію черевної порожнини провели всім хворим до повного видалення гнійного вмісту і фібрину. Дренування черевної порожнини виконали всім хворим через окремий доступ, з яких до зони розташування інфільтративно-абсцедуючого утворення - у 47 (63,51\%) і порожнини тазу - у 46 (62,16\%) хворих. у післяопераційному періоді встановили ускладнення з боку черевної порожнини у $10(13,51 \%)$ осіб і післяопераційної рани у 25 (33,78\%) хворих. Ускладнення післяопераційної рани мали такий характер: інфільтрат у 14 (18,92\%), сірому післяопераційної рани у 9 (12,16\%), нагноєння рани - у 3 (4,05\%) осіб (контрольної групи). Повторні операції були виконані 7 особам із 39 хворих контрольної групи, які перенесли першу операцію з причини ускладненого ДА. у таких осіб при релапаротомії встановили в черевній порожнині: кишковий вміст - у 2 (28,57\%) із 7 , гнійний вміст - у $2(28,57 \%)$ із 7 , інфільтративне утворення - у $3(42,85 \%)$ із 7 . Під час детальної ревізії виявили неспроможність швів купола сліпої кишки після апендектомії у $2(28,57 \%)$ із 7 , множинні міжпетльові абсцеси й абсцес правої здухвинної ділянки - у $2(28,57 \%)$ із 7, а інфільтративне утворення із залученням великого чіпця та петель кишечника у $3(42,85 \%)$ із 7 . у $5(71,42 \%)$ із 7 пацієнтів прошиті нитки на великому чіпці були залучені до формування як абсцесу, так і інфільтрату. 5 хворим, які мали межпетльові абсцеси й інфільтративне утворення, провели сегментарну резекцію великого чіпця, санацію та дренування черевної порожнини. Поміж тим, 2 (40,0\%) особам із 5 хворих, що мали міжпетльові абсцеси, провели 3 програмовані санаційні релапаротомії. На тлі калового перитоніту 1 хворому наклали цекостому, ще 1 пацієнтові ілеостому. у подальшому провели від 3 до 6 програмованих санаційних релапаротомій. На тлі тромбозу мезентеріальних судин та етапних резекцій тонкої кишки один хворий із супутнім ЦД помер. Хворий з цекостомою одужав, за місяць йому виконали закриту цекостому. Повторні операції були виконані 3 особам із 35 хворих досліджуваної групи, які перенесли першу операцію з причини ускладне- ного ДА. у таких пацієнтів при релапаротомії встановили в черевній порожнині: кишковий вміст у $2(66,66 \%)$ із 3, інфільтративне утворення - в $1(33,33 \%)$ із 3 пацієнтів. Обсяг операції включав проведення санації з накладенням окремих швів на дефект у ділянці культі апендикулярного паростка та накладення кінцевої ілеостоми. у подальшому для санації цим хворим провели санаційну лапароскопію, а за 3 доби - повторну релапароскопію із санацією черевної порожнини. у цілому виконали від 3 до 5 релапароскопічних санацій. Незважаючи на поліантибактеріальну та інфузійну терапію на тлі поліорганної недостатності 1 пацієнт помер. у другого пацієнта запальний процес у черевній порожнині мав зворотний характер, за 3 тижні після виписки 3 клініки хворому наклали тонко-тонкокишковий анастомоз «кінець у кінець». у хворого з інфільтративним утворенням під час релапаротомії мобілізували інфільтративне утворення із залученням великого чіпця (за допомогою гідроструменевого скальпеля) і провели його сегментарну резекцію.

До другої групи увійшли 48 (100,0\%) осіб із ПВ шлунка та дванадцятипалої кишки. Стан цих хворих на момент госпіталізації був тяжким - третя стадія перебігу виразкової хвороби (стадія перитоніту). Скарги на абдомінальний біль висловлювали всі хворі, на початку захворювання біль носив «кинджальний» характер - стадія абдомінального шоку, але за 6-8 год біль почав зменшуватися та поширюватися. у дослідженні встановили передумови «кинджального» болю: нудота - у 28 (58,33\%), порушення харчового режиму та переїдання - у 24 (50,0\%), блювання від однократного до багаторазового у 31 (64,58\%). Поміж тим, у 21 (43,75\%) пацієнта виявили декілька передумов. Локалізація болю була виразнішою в епігастральній ділянці у 15 (31,25\%) хворих та в доповненні по фланках та малого тазу у 33 (68,75\%) осіб. Підвищення загальної температури в межах $38,4 \pm 0,65^{\circ} \mathrm{C}$ мали всі хворі, а локальна температура була підвищеною на $2,12 \pm 0,65^{\circ} \mathrm{C}$ від норми у 22 (39,58\%) пацієнтів досліджуваної групи. Положення хворого було вимушеним (напівсидячим) у 39 (81,25\%) осіб, а сидячим із піднятими до живота ногами - у 9 (18,75\%). Пальпаторно біль був найінтенсивнішим у верхніх відділах черевної порожнини у $36(75,0 \%)$ осіб та в доповнення по фланках - у $14(29,17 \%)$ хворих. Усі хворі мали симптоми подразнення очеревини, різного ступеня вираженості, а також різке напруження м'язів, позитивний симптом Щоткіна-Блюмберга, а перкуторно - відсутня печінкова тупість - над печінкою «тимпаніт». у загальному аналізі крові виявили показники чер- 
воної крові $\mathrm{Hb}=98 \pm 4,72$ г/л, $\mathrm{Er}=2,9 \pm 0,86 \times 10^{12}$, а $\mathrm{L}=16,5 \pm 2,31 \times 10^{9}$ зі збільшенням сегментоядерних до $78 \pm 1,28 \%$, а також нейтрофілів (палочкоядерних) до $36 \pm 2,56 \%$. у другій групі хірургічне лікування провели у $48(100,0 \%)$ хворих із ПВ шлунка і дванадцятипалої кишки, які мали інфільтративно запальний процес великого сальника. Під час вибору операційного доступу врахували тривалість захворювання понад 24 год, вік понад 60 років, а також супутні захворювання серцево-судинної системи (атеросклероз, кардіосклероз, стентування). Тому хірургічний доступ в усіх 48 хворих - серединна лапаротомія. Під час ревізії черевної порожнини визначили локалізацію перфорації (шлунок і дванадцятипала кишка), розміри та ії краї, а також поширеність інфільтративно-запального процесу як черевної порожнини, так і великого чіпця. Локалізація перфоративної виразки шлунка була: вище 5 см до цибулини дванадцятипалої кишки - у 7 (14,58\%), у середній третині ближче до малої кривизни у 12 (25,0\%), по великій кривизні на дні шлунка у $14(29,17 \%)$, у центрі шлунка - у $9(18,75 \%)$, на рівні цибулини дванадцятипалої кишки - у 10 (20,83\%), у передній частині дванадцятипалої кишки у 3 (6,25\%), у нижній частині дванадцятипалої кишки - у $5(10,42 \%)$ хворих. Під час ревізії виразки їі кальозні краї виявили у $18(37,5 \%)$ осіб, а кровоточивість - у 5 (10,42\%) хворих. Накладення швів на перфоративну виразку проводилося після відділення великого сальника від виразки та висічення країв рани від кальозно-склеротичного процесу. Усім хворим наклали дворядні шви з обов'язковим контролем герметичності накладених швів, 3 обов'язковою декомпресією шлунка і кишечника (один зонд - у шлунку, а другий - за зв'язкою Трейця для ентерального введення рідини). Мобілізацію великого чіпця в контрольній групі провели механічним шляхом, а в досліджуваній групі застосували гідроструменевий скальпель у 18 (37,5\%) хворих, а 3 метою гемостазу використали апарат «LigaSure ${ }^{\mathrm{TM}}$ » у 22 (45,83\%) пацієнтів. Для прикриття виразки застосували пасмо великого сальника у $36(75,0 \%)$ хворих. Після санації провели дренування черевної порожнини з окремого доступу. Під час дренування черевної порожнини в контрольній групі використали однопросвітні дренажі у $26(54,17 \%)$, а в досліджуваній - двопросвітні у $22(45,83 \%)$ хворих. Неспроможності швів на ПВ не встановлено. Видалення дренажів провели за відсутності виділень і за відновлення перистальтики на 4-6-ту добу післяопераційного періоду. Післяопераційні ускладнення діагностували в 11 (22,92\%) хворих, з яких інтраабдомінальні - у $6(12,5 \%)$, а з боку рани у $5(10,42 \%)$ пацієнтів. Інтраабдомінальні ускладнення мали клініку некупованого перитоніту в $6(12,5 \%)$, з яких релапаротомію виконали $4(8,34 \%)$ особам, а лапароскопію - 2 (4,17\%) пацієнтам. Усім хворим провели санацію черевної порожнини з продовженням дренування останньої. у 5 (10,42\%) хворих виявили такі ускладнення: інфільтрат післяопераційної рани - у 2 (4,17\%), сірому післяопераційної рани - у 3 (6,25\%) пацієнтів. Консервативні заходи мали ефективне лікування. Повторні, релапаротомні операції в контрольній групі були проведені $4(15,38 \%)$ особам із 26 хворих із причини ПВ шлунка та дванадцятипалої кишки, абсцеси великого чіпця встановлені у $3(75,0 \%)$ із 4. Інфільтрат, як великого чіпця, так і з залученням стінок кишечника, був в $1(25,0 \%)$ із 4 хворих на тлі серозного вмісту в черевній порожнині. Проведена сегментарна резекція великого чіпця в межах здорових тканин з абсцесами та інфільтративними утвореннями з подальшою санацією черевної порожнини. На третю добу після релапаротомії зменшився шлунковий стаз, а в подальшому відновилася перистальтика та видалені дренажі. Повторні операчіі - лапароскопічні в досліджуваній групі були проведені 2 особам із 22 хворих, із яких міжпетльові абсцеси (3) встановили в $1(50,0 \%)$ із 2 хворих, а інфільтративне утворення великого чіпця - в $1(50,0 \%)$ із 2 пацієнтів. Лапароскопічно видалили інфільтративне утворення. Через 3 дні виконали повторну санаційну релапароскопію 2 пацієнтам, а ще через 3 дні - 1 хворому з абсцесами. Черевна порожнина - без гнійно-запальних утворень. Усі хворі одужали та виписані з клініки.

До третьої групи увійшли $69(100,0 \%)$ хворих із гострим запаленням холециститу (з різними варіантами ускладнень). Усі хворі висловлювали скарги на сильний біль черевної стінки в ділянці правого підребер'я. Лихоманку з $\mathrm{t}$ до $38,4 \pm 0,53^{\circ} \mathrm{C}$ виявили у $57(82,61 \%)$ осіб, озноб з $\mathrm{t}=39,6 \pm 0,87^{\circ} \mathrm{C}-$ у $12(17,39 \%)$ хворих. Блювання мали всі хворі, 3 яких нестерпне (постійне) - 45 (65,22\%), багаторазове - $16(23,19 \%)$, однократне з постійною нудотою - 8 (11,59\%) пацієнтів. Усі хворі мали тахікардію до Ps $=115 \pm 3,54$ на 1 хвилину та дихання ЧД=35 $\pm 2,27$ на 1 хвилину. При огляді живіт (верхні його відділи) не брав участі в диханні. При пальпації виявили біль у правому підребер'ї, з позитивними симптомами Мерфі та Ортнера. Лабораторні дослідження такі: лейкоцитоз зі зсувом лейкоцитарної формули вліво, $\mathrm{L}=14,5 \pm 1,58 \times 10^{9}$ у $32(46,38 \%)$ хворих, а L $=22,4 \pm 1,12 \times 10^{9}-$ у $37(53,62 \%)$. Зсув формули вліво та 


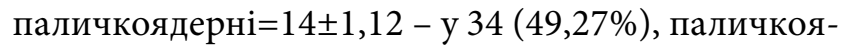
дерні=28 2,11 - у 35 (50,72\%). Підвищену концентрацію С-реактивного білка у сироватці крові до $15 \pm 1,29$ мг/л виявили у всіх хворих. Гіпербілірубінемію з показниками до 23,1 1,14 мкмоль/л у $47(68,12 \%)$, понад $31,2 \pm 1,21$ мкмоль/л у 22 (31,88\%). УЗД дослідження провели 30 (43,48\%) хворим досліджуваної групи. За результатами УЗД встановили: наявність конкрементів у $25(36,23 \%)$, набряк стінки жовчного міхура у 30 (43,48\%), наявність газу в стінці - у 21 (30,43\%), позитивний ультрасонографічний симптом Мерфi - у 30 (43,48\%), збільшення жовчного міхура у 30 (43,48\%), потовщення стінки жовчного міхура - у $30(43,48 \%)$, зміни у просвіті жовчного міхура - у 5 (7,25\%), скупчення рідини навколо жовчного міхура - у 24 (34,78\%), інфільтративний перивезикальний процес - у 6 (8,69\%). Враховуючи, що $16(23,19 \%)$ пацієнтів скаржилися і на больовий синдром у нижніх відділах живота з порушенням спорожнення, провели ректальне дослідження і виявили нависання передньої стінки у 5 (7,25\%) хворих. Таким чином, за результатами обстеження в контрольній групі з 37 (53,62\%) хворих абсцеси черевної порожнини відмітили у 35 (50,72\%), а інфільтрати - у 2 (2,90\%) пацієнтів. Хірургічне лікування виконали 69 (100\%) хворим, які страждали на ускладнений холецистит. Хірургічний доступ обгрунтували за результатами комплексного обстеження. Лапаротомію провели 43 (62,32\%) хворим, з яких 37 особам контрольної групи та 6 хворим досліджуваної, а лапароскопію - 26 (37,68\%) пацієнтам досліджуваної групи, з яких 5 (7,25\%) особам провели конверсію через виражений спайково-склеротичний процес у черевній порожнині. Під час ревізії як при лапаротомії, так і при лапароскопії встановили, що у всіх 69 хворих в організації інфільтративно-абсцедуючого утворення брав участь жовчний міхур, великий сальник, а у 18 (26,08\%) - і стінки товстої кишки. Розділення інфільтративного утворення провели механічним шляхом 37 (53,62\%) хворим контрольної групи, а в досліджуваній - в 11 (15,94\%) хворих використовували гідроструменевий скальпель і апарат «LigaSure ${ }^{\mathrm{TM}}$ ». Вторинні зміни у великому сальнику були показанням до резекції останнього від сегментарної до субтотальної, із застосуванням швів у контрольній групі, та біполярної коагуляції апа-

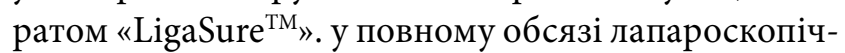
ну холецистектомію виконали 21 (30,43\%) особам із 32 хворих. Резекцію сальника різних за обсягом (крайова, сегментарна, субтотальная) провели
29 (42,03\%) пацієнтам. Усі операції закінчили дренуванням черевної порожнини. Післяопераційні ускладнення діагностували у 12 (17,39\%) пацієнтів, 3 яких інтраабдомінальні - у 9 (13,04\%), з боку рани - у 3 (4,35\%). Інтраабдомінальні ускладнення у $9(13,04 \%)$ хворих мали клініку не купованого перитоніту, у зв'язку з чим 4 (5,79\%) пацієнтам провели санаційну релапаротомію, а 5 (7,25\%) - санаційну лапароскопію. 33 (4,35\%) пацієнтів виявили нагноєння післяопераційної рани у 2 (2,90\%) хворих контрольної групи і в $1(1,45 \%)$ особи досліджуваної групи. Санацію гнійної рани досягли зняттям швів, купіруванням запального процесу і накладенням вторинних швів. Повторні операціі в контрольній групі - релапаротомії провели $6(16,21 \%)$ особам із 37 хворих. Абсцеси великого чіпця виявили у 4 (66,66\%) із 6 пацієнтів, а інфільтративне утворення - у $2(33,34 \%)$ із 6 хворих на тлі серозного перитоніту. Під час ревізії встановили спроможність швів культі кукси жовчної протоки. Провели сегментарну резекцію великого чіпця, що мав як абсцедуючі утворення, так і інфільтративні зміни з подальшою санацією та дренуванням черевної порожнини. Відновлення перистальтики почалося з 4-ї доби після релапаротомії, а на 5-ту добу були видалені дренажі. Повторні операціi в досліджуваній групі провели лапароскопічно $3(9,37 \%)$ особам із 32 хворих, які перенесли операцію $з$ причини ДХ, а дані ревізії показали наявність міжпетльових абсцесів у 2 (66,66\%) із 3 пацієнтів та інфільтративне утворення в $1(33,34 \%)$ із 3 пацієнтів. Лапароскопічно провели санацію міжпетльових абсцесів і видалили інфільтративне утворення великого чіпця. У подальшому хворим, які мали абсцеси, провели по 3 санаційні релапароскопії до повного призупинення запального процесу. Усі хворі одужали та виписані з клініки.

До четвертої групи увійшли 27 (100,0\%) хворих, які перенесли ургентні інтраабдомінальні операції 3 причини: непрохідності кишечника - 14 (51,85\%), ускладнених защемлених гриж різної локалізації 13 (48,15\%). у цій групі вторинні післяопераційні пухкі інфільтративні, абсцедуючі та рідинні утворення встановили у 15 (55,55\%) хворих контрольної групи і у 12 (44,45\%) осіб досліджуваної групи, а залежно від ускладнення: інфільтрати - у 6 (22,22\%), абсцеси - у $3(11,12 \%)$, рідинні утворення у 18 (66,66\%) осіб. у контрольній групі з 15 хворих встановили: інфільтрати - у 4 (14,81\%), абсцеси у 3 (11,12\%), рідинні утворення - у 8 (26,63\%). У досліджуваній групі з 12 хворих діагностували: інфільтрати - у 2 (7,41\%), рідинні утворення - 
у $10(37,04 \%)$. Дослідження хворих за статтю показало, що серед хворих було $11(40,74 \%)$ чоловіків і $16(59,26 \%)$ жінок, з яких у контрольній групі відповідно $4(14,81 \%)$ і 11 (40,74\%) хворих, а в досліджуваній - відповідно 7 (25,92\%) і 5 (18,53\%) пацієнтів. Залежності від віку і статі встановили такі дані: від 25 до 54 років - $8(29,63 \%)$ осіб, із них $3(11,11 \%)$ чоловіки і $5(18,52 \%)$ жінок; від 55 до 64 років - $9(33,33 \%)$ пацієнтів, із них $5(18,52 \%)$ чоловіків і $4(14,81 \%)$ жінки; від 65 років - 10 (37,04\%) хворих, 3 них 3 (11,11\%) чоловіки і 7 (25,93\%) жінок. Дослідженнями встановлено кількість госпіталізованих хворих залежно від місяця року та кварталу року: І квартал - 9 (33,33\%), II квартал - 5 (18,52\%), III квартал - 6 (22,22\%), IV квартал - 7 (25,93\%) осіб. у всіх хворих тривалість захворювання була понад 24 год. Клінічна картина була типовою для непрохідності кишечника: з ознаками странгуляційної спайкової непрохідності - у 14 (51,85\%), защемлені грижі різної локалізації - у 13 (48,15\%). 3 огляду на відсутність перитоніту при першій операції, дренування черевної порожнини не проводили. у післяопераційному періоді всі хворі лихоманили: до $38,0^{\circ} \mathrm{C}$ - у $16(59,26 \%)$ пацієнтів, а понад $38,1^{\circ} \mathrm{C}$ - в $11(40,74 \%)$ осіб. Післяопераційний моніторинг загального аналізу крові свідчив про прогресування інтраабдомінального запального процесу: лейкоцити $38,6 \pm 1,3 \times 10^{9}$ упродовж 3 діб збільшилися до $19,9 \pm 1,5 \times 10^{9}$ у $24(88,89 \%)$ хворих. Зсув формули вліво та паличкоядерні з $6 \pm 1,12$ (на 2-гу добу після операції) збільшилися до $23 \pm 2,38$ (на 4-ту) у 24 (88,89\%) хворих. Дисфагічні розлади мали всі хворі, незважаючи на декомпресію шлунка. Так, нудоту мали $3(11,11 \%)$ хворі, а блювання на 2-гу добу 6 (22,22\%), на 3-ю добу - 18 (66,67\%) хворих, з яких блювання нестримного характеру - $6(22,22 \%)$ пацієнтів. Живіт мав збільшений вигляд у $24(88,89 \%)$ хворих. Пальпаторно визначили болючість ділянки післяопераційної рани, а також від пупка до лона. Аускультативно не виявили перистальтики у $24(88,89 \%)$ хворих, а у $3(11,11 \%)$ була різко ослабленою. Ректальне дослідження було інформативним - встановили болючість і нависання у 14 (51,85\%) хворих. Таким чином, у всіх 27 хворих у післяопераційному періоді виявили інтраабдомінальні ускладнення: абсцедуючі інфільтрати у $8(29,63 \%)$ пацієнтів, абсцеси - у 19 (70,37\%) хворих. Повторні операції всім 15 (55,55\%) хворим контрольної групи були проведені шляхом релапаротомії. Під час ревізії черевної порожнини у 9 хворих контрольної групи, які перенесли операцію 3 причини спайкової непрохідності, виявили: перито- ніт (як гнійний, так і з домішками кишкового вмісту) та неспроможність швів анастомозу у $2(22,22 \%)$ з 9, множинні тонкокишкові перфорації - у $2(22,22 \%)$ з 9 хворих, а міжпетльові абсцеси - у $2(22,22 \%)$ з 9. Інфільтративні утворення відмітили у $3(33,33 \%)$ з 9 пацієнтів із локалізацією в ділянках пошкодження серозної оболонки, а основним утворюючим складовим інфільтрату був великий чепець. Сегментарну резекцію тонкої кишки провели $4(44,44 \%)$ особам 39 хворих та наклали ілеостому, а в подальшому виконали їм від 5 (71,42\%) до 7 програмованих санаційних лапаротомій. у $3(75,0 \%)$ із 4 хворих розвинувся тромбоз брижових судин з етапним реілеостомуванням і поліорганною недостатністю з летальним наслідком. Натомість, 1 (25,0\%) хворому з 4 пацієнтів після 2 санаційних програмованих релапаротомій через місяць виконали операцію закриття ілеостоми з накладенням прямого тонкокишкового анастомозу «кінець у кінець». Усім хворим на етапах оперативного лікування - релапаротомії провели сегментарну резекцію великого чіпця в межах здорових тканин, санацію і дренування черевної порожнини. За даними релапаротомії та ревізії черевної порожнини, 6 хворих контрольної групи перенесли попередню операцію ускладнених гриж із резекцією ділянки тонкої кишки та накладення прямого анастомозу, а при повторній ревізії встановлено неспроможність анастомозу з виходом крізь дефект кишкового вмісту, а як наслідок, каловий перитоніт та множинні міжпетльові абсцеси та інфільтративні утворення у хворих. Наявність калового перитоніту слугувала показанням до накладення ілеостомії всім хворим із подальшим проведенням програмованої санаційної релапаротомії від 4 до 6, а їх кількість визначали станом і вмістом черевної порожнини. Незважаючи на поліантибактеріальну терапію та проведення програмованих санаційних релапаротомій, у $4(66,66 \%)$ із 6 хворих розвинулася клініка тромбозу мезентеріальних судин, що потребувало етапного реілеостомування. На тлі поліорганної недостатності померли 4 пацієнти. А $2(33,34 \%)$ особам із 6 хворих, після купірування перитоніту шляхом програмованих санаційних релапаротомій та дренування черевної порожнини, через місяць наклали тонкотонкокишковий анастомоз «кінець у кінець», пацієнти одужали та виписані з клініки. Повторні операції в досліджуваній групі були проведені $12(44,45 \%)$ хворим, з яких після спайкової непрохідності - $10(83,33 \%)$ із 12, після операцій з причини гриж - $2(16,67 \%)$ із 12 . Після усунення спайкової непрохідності післяопераційними ускладненнями 
були рідинні утвори у $6(60,0 \%)$ осіб із 10 хворих та інфільтративні утворення в $4(40,0 \%)$ пацієнтів із 10 хворих. Натомість, після ускладнених гриж ускладнення у вигляді рідинних утворів виявили у 2 пацієнтів. Основним методом інвазійного лікування був ендоскопічний метод - лапароскопія та релапароскопія. Лапароскопічну ревізію черевної порожнини провели всім 12 хворим досліджуваної групи. у 10 хворих, які перенесли спайкову непрохідність, під час лапарокопії виявили: перитоніт у $4(40,0 \%)$ на тлі неспроможності міжкишкового анастомозу, гнійний вміст значної кількості у 2 (20,0\%). Лапароскопічно у 4 (40,0\%) з 10 хворих діагностували інфільтративні утворення із залученням великого чіпця (видалили разом із інфільтратом). Поміж тим, неспроможність міжкишкового анастомозу слугувала показанням до конверсії та релапаротомії. Інтраопераційно 4 хворим провели сегментарну резекцію з ілеостомією на тлі тотального гнійного та калового перитоніту. у подальшому провели санаційні лапароскопії, a кількість визначили індивідуально - від 3 до 5. у $2(50,0 \%)$ із 4 хворих після санаційної релапароскопії зберігався серозний вміст у черевній порожнині, а тому їм провели пункцію під контролем УЗД - без ускладнень. Поміж тим, у $2(50,0 \%)$ із 4 пацієнтів на тлі поліантибактеріальної та інфузійної терапії розвинулася поліорганна недостатність, 2 (25,0\%) хворі померли. А 2 (50,0\%) особам із 4 хворих після 5 санаційних релапароскопій, а також після відновного лікування через 4 тижні виконали закриту ілеостому шляхом накладення тонко-тонкокишкового анастомозу «кінець у кінець». у досліджуваній групі за даними лапароскопічної ревізії черевної порожнини, проведеної 2 хворим, які перенесли операцію з причини защемлених і ускладнених гриж, встановили: рідинне утворення - в 1 хворого, яке лапароскопічно сановане; кишковий вміст - в 1 хворого (провели конверсію та релапаротомію). Причиною наявності кишкового вмісту був сегментарний некроз із множинними мікроперфораціями тонкої кишки, тому провели сегментарну резекцію, а на тлі гнійного перитоніту наклали ілеостому. у подальшому провели 4 санаційні лапароскопії з метою припинення поширення гнійного вмісту. В 1 (50,0\%) із 2 хворих зберігався серозний вміст у черевній порожнині - провели пункцію під контролем УЗД без ускладнень. В 1 (50,0\%) із 2 хворих, незважаючи на комплексне лікування, виник тромбоз мезентеріальних судин із проведенням етапних операцій та летальним наслідком. у другого хворого, який мав ілеостому, останню закрили через місяць шляхом накладення анастомозу «кінець у кінець».

На завершення доцільно вказати, що до дослідження увійшли 218 хворих, які були як госпіталізовані, так і прооперовані за ургентними показаннями. у контрольній групі було 117 хворих, з яких 102 особи мали первинні інтраабдомінальні ускладнення, а 15 пацієнтів перенесли як спайкову непрохідність, так і ускладнені грижі. Серед 102 хворих із первинними інтраабдомінальними ускладненнями інфільтрати відмічалися у 27 осіб, а абсцеси у 75 хворих. у післяопераційному періоді у 102 хворих спостерігалися такі післяопераційні ускладнення: інтраабдомінальні - у 17 (абсцеси - в 11, інфільтрати - у 6), а ускладнення з боку ранового каналу - у 23. Ускладнення з боку ранового каналу відмічалися при ДА у 18 осіб (3 - нагноєння післяопераційної рани, 9 - інфільтрати післяопераційної рани, 6 - серома післяопераційної рани), при ПВ у 3 (2 - нагноєння післяопераційної рани, 1 - серома післяопераційної рани), при ДХ - у 2 (2 - нагноєння післяопераційної рани) хворих. у контрольній групі після інтраабдомінальних операцій з причини спайкової непрохідності та ускладнених гриж післяопераційні ускладнення відмічалися у 15 хворих, із яких інфільтрати - у 4, рідинні утворення - у 8, абсцеси у 3. Таким чином, у цій групі серед 117 хворих релапаротомія (від 2 до 5) проводилася 32 пацієнтам, 3 яких неспроможність стінки кишки та кишкових швів відмічалася в 11 хворих, а повторна резекція тонкої кишки з накладенням ілеостоми проводилася 7 особам, а цекостоми - 1 хворому. Власне в контрольній групі померло 8 (6,84\%) хворих на тлі продовжуваного перитоніту, тромбозу мезентеріальних судин та поліорганної недостатності і супутніх захворювань.

Натомість, до досліджуваної групи увійшов 101 пацієнт, з яких 89 хворих мали первинні інтраабдомінальні ускладнення, а 12 осіб перенесли як спайкову непрохідність, так і ускладнені грижі. Основними хірургічними технологіями в лікуванні були ендовідеоскопічна (лапароскопія та релапароскопія), а при розділенні інтрабдомінального процесу - гідроструменевий скальпель. Поміж тим, ускладнення з боку післяопераційної рани відмічалися в 11 хворих, з яких при ДА - у 8 (5 - інфільтрат післяопераційної рани, 3 - серома пяляопераційної рани), при ПВ - у 2 (2 - інфільтрат післяопераційної рани), при ДХ - в 1 (1 - нагноєння післяопераційної рани). Інтраабдомінальні ускладнення спостерігалися у 20 пацієнтів, з яких абсцеси - у 5, інфільтрати - у 5, а рідинні утворення - у 10 хворих. Лапарос- 
копічно встановлено, що абсцеси й інфільтрати великого чіпця були у 9 з 16 хворих, а неспроможність стінки кишки і кишкових швів - у 7 пацієнтів. Резекція тонкої кишки з накладенням ілеостоми проводилася у 7 хворих. Померло 4 (3,96\%) хворих на тлі продовжуваного перитоніту, тромбозу мезентеріальних судин і поліорганної недостатності.

\section{Обговорення}

Обговорення проблеми доцільно почати з вітчизняних даних. Так, П.Д. Фомін і співавт. (2018) звернули увагу, що в Україні гостре запалення апендикулярного паростка становить 20,7 на 10 тис. населення, при цьому в частини хворих при пізньому зверненні розвивається перитоніт. Тим часом, летальність при ДА зумовлена такими чинниками: тяжкістю захворювання - 19,7\%; пізньою госпіталізацією - 46,1\%; технічними помилками під час операції - 5,2\%; тактичними помилками - $6,8 \%$; дефектами післяопераційного лікування - 7,7\%; супутніми захворюваннями - 9,3\%; пізньою операцією - 5,2\%. Гострий холецистит становить 6,25 на 10 тис. населення 3 коливанням від 1,48 до 10,8 на 10 тис. населення в різних регіонах. у 94-96\% хворих причиною виникнення хвороби є жовчнокам'яна хвороба. Післяопераційна летальність складає в середньому 0,81-0,94\%, а при пізній госпіталізації 46,3-46,5\%, а кількість госпіталізованих пізніше 24 год від початку захворювання - 12,3-51,7\%. Перфоративні гастродуоденальної виразки становлять 1,88 на 10 тис. населення 3 коливанням від 1,08 до 2,57 на 10 тис., а післяопераційна летальність - 3,44\% (0,64-5,64\%). Кількість пізно госпіталізованих пацієнтів дорівнює 0-20\% (у середньому - 12,5\%) при післяопераційній летальності серед госпіталізованих пізніше 24 год від початку захворювання 13,73\% (у середньому - 0-33,3\%). Гостра непрохідність кишечника посідає п’яте місце за поширеністю і становить понад 5\% серед гострих хірургічних захворювань черевної порожнини. Водночас, за летальністю в абсолютних цифрах ця патологія займає одне з перших місць серед усіх гострих захворювань органів черевної порожнини. Грижі передньої черевної стінки складають 3-4\% усього населення (2,64 (у середньому - 0,45-4,07) на 100 тис. населення), а у 3-27\% хворих розвиваються ускладнення, що потребують оперативного лікування $[7,10]$.

За даними Di Saverio і співавт. (2020), які, описуючи історію захворюваності на ДА, вказали, що рівень захворюваність на цю патологію неухильно знижується з кінця 1940-х років ХХ століття. Так, у розвинених країнах ДА зустрічається від 5,7-
50 пацієнтів на 100 тис. жителів на рік, з піком у віці від 10 до 30 років. Встановлено також географічні відмінності: так, довічний ризик виникнення ДА становить 9\% у США, 8\% - в Європі, 2\% - в Африці. Більше того, існують відмінності в методах обстеження й лікування пацієнтів, пов'язані з доходом у державі. у роботі акцентовано, що частота перфорації ДА коливається від 16\% до 40\%, у молодших вікових групах $-40-57 \%$, а в пацієнтів віком від 50 років - 55-70\%. Летальність при неперфоративному апендициті становить менше $0,1 \%$, але ризик зростає до 0,6\% при гангренозному паростку. 3 іншого боку, автори зазначили, що перфорація апендициту має вищий рівень смертності приблизно на 5\% [3]. Olanrewaju Samuel Balogun і співавт. (2019) в дослідженні ДА серед дорослих вказали, що частота перфорації становить 28,5\%, а загальний рівень ускладнень - 43,1\%. Акцентовано увагу, що найчастішими ускладненнями $€$ інфекції ділянки хірургічного втручання - $18,6 \%$, розбіжність післяопераційної рани - 15,2\%, абсцес порожнини таза - 13,5\% [2]. На сьогодні відводиться значна роль діагностичній візуалізації апендициту: УЗД, КТ і МРТ, що є важливим моментом у діагностиці захворювання. Наведені післяопераційні ускладнення, такі як ранова інфекція, інтраабдомінальний абсцес і кишкова непрохідність, становлять до $11,1 \%[11,16]$.

У своїй роботі Varut Lohsiriwat і співавт. (2009) провели аналіз лікування перфорованої виразкової хвороби у 152 пацієнтів (середній віковий діапазон 15-88 років), з яких 78\% чоловіків. Найчастішою локалізацією перфорованої виразкової хвороби була препілорична ділянка (74\%). Під час операції найпоширенішою процедурою було застосування великого сальника для закриття виразки. Частота ускладнень становила $30 \%$, а рівень загальної летальності - 9\%. 3 метою прогнозування післяопераційних ускладнень і летальності використовувалася шкала Воеу (Американського товариства анестезіологів), яка порівняно з індексом перитоніту Мангейма (Mannheim Peritonitis Index) є простим i точним предиктором [6].

В аналітичній роботі F. Ausania і співавт. (2015) вказують, що перфорація жовчного міхура - небезпечне для життя ускладнення гострого холециститу, зустрічається приблизно у 2-11\% пацієнтів. Автори на основі вивчення карток 1033 хворих виявили у 137 пацієнтів перфорацію жовчного міхура, що становило $12,4 \%$. За результатами лікування показники захворюваності і смертності дорівнювали 57,7\% і 9,5\% відповідно [1]. Stefan Jansen і співавт. (2018) порівняли результати лікування перфо- 
ративного і неперфоративного холециститу. Автори показали, що рівень захворюваності становить $24 \%$ проти $7 \%$, смертності - $8 \%$ проти $1 \%$, показник конверсії - $22 \%$ проти $4 \%$, тривалість операції - $131,3 \pm 55,2$ хв проти $100,4 \pm 47,9$ хв, а також загальна тривалість перебування - $11,2 \pm 12,0$ доби проти 5,8 $\pm 6,5$ доби (при перфоративному холециститі значно довше порівняно з групою без перфораціï) [5].

В.В. Скиба і співавт. (2017), з метою розділення інфільтративно-запального та абсцедуючого утворення, застосували гідроструменевий скальпель, який дав змогу провести операцію без пошкодження серозної оболонки - безкровно $[14,15]$. Проте як КТ, так і СКТ є дороговартісними (але точними в більшості пацієнтів) методами обстеження, що потребує певного часу для проведення, а також наявності апаратів. А тому В.Ф. Рибальченко, Ю.Г. Демиденко $(2018,2019,2020)$ розробили, запатентували та запровадили в обстеженні хворих на інтраабдомінальні інфільтрати і абсцеси вимірювання температури передньої черевної стінки у всіх квадратах інфрачервоним термометром. у подальшому автори розробили «Термометричну панель передньої черевної стінки і прогностичний аксилярно-абдомінальний коефіцієнт» та отримали патент. Власне метод $€$ інформативним та ефективним як у діагностиці інтраабдомінальних гнійних захворювань, так і в прогнозуванні післяопераційного перебігу захворювання (щоденне вимірювання температури у всіх ділянках), при цьому не потребує фінансових вкладень і може проводитися в приймальному відділенні черговим хірургом $[11,12]$.

S. Massimo і співавт. (2017) провели багатоцентрове дослідження в 132 установах по всьому світу протягом 4-місячного періоду (жовтень 2014 року - лютий 2015 року). Дослідження охоплювало 4553 пацієнтів, які мали внутрішньочеревну інфекцію і отримували антибактеріальну терапію. За результатами дослідження, загальний рівень летальності становив 9,2\% [13].

На завершення слід акцентувати, що, незважаючи на певні досягнення, проблема вчасної діагностики, грунтовного обстеження і хірургічного лікування залишається не вирішеною з соціально-економічних причин.

\section{Висновки}

Обстеження 218 хворих показали, що первинні інтраабдомінальні інфільтрати й абсцеси встановлені: при ДА - у 74 (33,94\%) хворих, при ДХ у 69 (31,65\%) пацієнтів, при ПВ шлунка та дванадця- типалої кишки - у 48 (22,02\%) осіб, а вторинні післяопераційні - у 27 (12,39\%) пацієнтів, які перенесли ургентні операції на черевній порожнині (спайкова непрохідність, защемлені і післяопераційні грижі та інші), та у 29 (15,18\%) з 191 хворого, які перенесли операції з приводу первинних інтраабдомінальних ускладнень основного захворювання та ургентної операції.

Післяопераційні ускладнення діагностовані у $43(19,72 \%)$ хворих, з яких із боку операційної рани - у 34 (15,59\%), черевної порожнини у $29(15,18 \%)$ пацієнтів, які потребували проведення релапаротомії чи лапароскопії: при ДА - у 13,51\%, при ПВ шлунка та дванадцятипалої кишки - у $12,5 \%$, при ДХ - у 13,04\%, при спайковій кишковій непрохідності - у 18,57\%, при защемлених і ускладнених грижах - у 17,72\% обстежених хворих.

Хірургічне лікування $є$ індивідуальним залежно від захворювання. Так, при ДА з 74 (38,74\%) пацієнтів лапаротомія проведена $42(21,99 \%)$ хворим, лапароскопія - 32 (16,75\%) особам, а 12 (6,28\%) пацієнтам - із конверсією; при ПВ шлунка та дванадцятипалої кишки виконана відкрита лапаротомія $48(25,13 \%)$ особам; при холециститі з $69(36,13 \%)$ хворих лапаротомія проведена $48(25,13 \%)$ особам, а лапароскопія - 21 (11,00\%) пацієнтові.

Застосування новітніх візуалізаційних і лікувальних технологій (допплерографії, гідроструменевого скальпеля та лапароскопії) у 64 (33,51\%) дало змогу отримати кращі близькі і віддалені результати з урахуванням якості життя та знизити рівень післяопераційної летальності з 6,84\% до 3,96\% при середньому показнику 5,5\%.

Автори заявляють про відсутність конфлікту інтересів.

\section{References/Література}

1. Ausania F, Guzman Suarez S, Alvarez Garcia H, Senra del Rio P, Casal Nuñez E. (2015, Apr). Gallbladder perforation: morbidity, mortality and preoperative risk prediction. Surg Endosc. 29 (4): 955-960. doi: 10.1007/s00464-014-3765-6. Epub 2014 Aug 27.

2. Balogun Olanrewaju Samuel, Osinowo Adedapo, Afolayan Michael, Olajide Thomas, Lawal Abdulrazzak, Adesanya Adedoyin. (2019, Jan-Mar). Acute Perforated Appendicitis in Adults: Management and Complications in Lagos, Nigeria. Ann Afr Med. 18 (1): 36-41. PMC6380116. doi: 10.4103/aam.aam_11_18.

3. Di Saverio et al. (2020). Diagnosis and treatment of acute appendicitis: 2020 update of the WSES Jerusalem guidelines. World Journal of Emergency Surgery. 15: 27. doi. org/10.1186/s13017020-00306-3.

4. Fomin PD, Usenko OIu, Bereznytskyi YaS. (2018). Nevidkladna khirurhiia orhaniv cherevnoi porozhnyny (standarty orhanizatsii ta profesiino oriientovani alhorytmy nadannia medychnoi dopomohy). K.: Biblioteka «Zdorovia Ukrainy»: 354. [Фомін ПД, Усенко ОЮ, Березницький ЯС. (2018). Невідкладна 


\section{Оригінальні дослідження. Абдомінальна хірургія}

хірургія органів черевної порожнини (стандарти організації та професійно орієнтовані алгоритми надання медичної допомоги). К.: Бібліотека «Здоров’я України»: 354].

5. Jansen Stefan, Stodolski Maciej, Zirngibl Hubert, Gödde Daniel, Ambe Peter C. (2018, Feb 23). Advanced gallbladder inflammation is a risk factor for gallbladder perforation in patients with acute cholecystitis. World Journal of Emergency Surgery. 13: 9. doi: 10.1186/s13017-018-0169-2.

6. Lohsiriwat V, Prapasrivorakul S, Lohsiriwat D. (2009). Perforated Peptic Ulcer: Clinical Presentation, Surgical Outcomes, and the Accuracy of the Boey Scoring System in Predicting Postoperative Morbidity and Mortality. World J Surg. 33: 80-85. doi. org/10.1007/s00268-008-9796-1.

7. MOZ Ukrainy. (2016). Unifikovanyi klinichnyi protokol ekstrenoi, pervynnoi ta vtorynnoi (spetsializovanoi) medychnoi dopomohy. Hostryi apendytsyt. Kyiv: 75. [MО3 України. (2016). Уніфікований клінічний протокол екстреної, первинної та вторинної (спеціалізованої) медичної допомоги. Гострий апендицит. Київ: 75].

8. Rusak PS. (2006). Maloinvazyvni tekhnolohii v likuvanni abstsesiv cherevnoi porozhnyny u ditei. Khirurhiia dytiachoho viku. III; 4 (13): 23-25. [Русак ПС. (2006). Малоінвазивні технології в лікуванні абсцесів черевної порожнини у дітей. Хірургія дитячого віку. III; 4 (13): 23-25].

9. Rusak PS. (2013). Likuvannia abstsesiv cherevnoi porozhnyny iz zastosuvanniam laparoskopii. Khirurhiia Ukrainy. 3 (47): 71-76. [Русак ПС. (2013). Лікування абсцесів черевної порожнини із застосуванням лапароскопії. Хірургія України. 3 (47): 71-76]

10. Rusak PS. (2018). Minimally invasive technologies in the treatment of abdominal abscesses in children. Paediatric surgery. Ukraine. 3 (60): 61-65. [Русак ПС. (2018). Мініінвазивні технології у лікуванні абсцесів черевної порожнини у дітей. Хірургія дитячого віку. 3 (60): 61-65]. doi 10.15574/ PS.2018.60.61.

11. Rybalchenko VF, Demydekno YuH. (2019). Termometrychna panel perednoi cherevnoi stinky ta prohnostychnyi aksyliarnoabdominalnyi koefitsiient. Neonatolohiia, khirurhiia ta perynatalna medytsyna. 9; 3 (33): 86-94. [Рибальченко ВФ, Демидекно ЮГ. (2019). Термометрична панель передньої черевної стінки та прогностичний аксилярно-абдомінальний коефіцієнт. Неонатологія, хірургія та перинатальна медицина. 9; 3 (33): 86-94]. doi: 10.24061/2413-4260.IX.3.33.2019.5.

12. Rybalchenko VF, Demydenko YuH, Yarmak SIa. (2018). Termometrychna panel perednoi cherevnoi stinky u ditei $\mathrm{z}$ in- filtratamy, abstsesamy apendykuliarnoho pokhodzhennia ta prohnostychnyi aksyliarno-abdominalnyi koefitsiient. Paediatric surgery. Ukraine. The materials of conference. 2 (59): 96. [Рибальченко ВФ, Демиденко ЮГ, Ярмак СЯ. (2018). Термометрична панель передньої черевної стінки у дітей з інфільтратами, абсцесами апендикулярного походження та прогностичний аксилярно-абдомінальний коефіцієнт. Xiрургія дитячого віку. Матеріали з'їзду. 2 (59): 96].

13. Sartelli Massimo, Chichom-Mefire Alain, Catena Fausto. (2017). The management of intra-abdominal infections from a global perspective: 2017 WSES guidelines for management of intraabdominal infections. World Journal of Emergency Surgery. Article number 29. 12 (12): 36.

14. Skyba VV, Rybalchenko VF, Ivanko OV, Zinchuk AG, Badakh VM, Bocharov VP. (2017). The surgical treatment of an abdominal cavity infiltrations among adolescents using jet hydro scalpel. Paediatric surgery. Ukraine. 1 (54): 32-38. [Скиба ВВ, Рибальченко ВФ, Іванько ОВ, Зінчук ОГ, Бадах ВМ, Бочаров ВП. (2017). Хірургічне лікування інфільтратів черевної порожнини у підлітків з використанням струменевого гідроскальпеля. Хірургія дитячого віку. 1 (54): 32-38]. doi: 10.15574/PS.2017.54.32.

15. Skyba VV, Rybalchenko VF, Ivanko OV, Demydenko YuH, Badakh VM, Bocharov VP. (2017). Khirurhichne likuvannia zapalnykh i spaikovykh protsesiv cherevnoi porozhnyny u pidlitkiv iz vykorystanniam strumenevoho hidroskalpelia. Zdorove rebenka. 12; 1: 68-74. [Скиба ВВ, Рибальченко ВФ, Іванько ОВ, Демиденко ЮГ, Бадах ВМ, Бочаров ВП. (2017). Хірургічне лікування запальних і спайкових процесів черевної порожнини у підлітків із використанням струменевого гідроскалпеля. Здоровье ребенка. 12 (1): 68-74]. URL: http:// nbuv.gov.ua/UJRN/Zd_2017_12_1_14.

16. Salomone DI, Saverio Mauro, Podda Fausto Catena. (2020) Diagnosis and treatment of acute appendicitis: 2020 update of the WSES Jerusalem guidelines. World Journal of Emergency Surgery. $15 ; 27$. https://wjes.biomedcentral.com/articles/10.1186/ s13017-020-00306-3\#citeas

17. Zaremba YeKh, Zaremba VS, Rak NO, Hirniak OT, Zaremba OV, Burmai SV. (2020). Peryvezykalnyi infiltrat zhovchnoho mikhura z poshyrenniam na pidpechinkovyi prostir (klinichnyi vypadok). Praktykuiuchyi likar. 3-4: 10-15. [Заремба ЄX, Заремба ВС, Рак НО, Гірняк ОТ, Заремба ОВ, Бурмай СВ. (2020). Перивезикальний інфільтрат жовчного міхура з поширенням на підпечінковий простір (клінічний випадок). Практикуючий лікар. 3-4: 10-15].

\section{Відомості про авторів:}

Скиба Володимир Вікторович - д.мед.н., академік АНВШ, проф., директор «Центру хірургї» КНП «Київська міська клінічна лікарня №1», зав. каф хірургічних хвороб №1 ПВНЗ «Київський медичний університет», зав. каф. хірургії, анестезіології та інтенсивної терапії ІПО НМУ імені О.О. Богомольия, Засл. діяч науки і техніки України, Лауреат державної премії України в галузі науки і техніки. Адреса: м. Київ, Харківське шосе, 121. https://orcid.org/0000-0002-7681-4217.

Рибальченко Василь Федорович - д.мед.н., проф., проф. каф. дитячої хірургї̈ НУОЗ України імені П.Л. Шупика МОЗ України, проф. каф. хірургічних хвороб №1 ПВНЗ «Київський медичний університет». Адреса: м. Київ, вул. Дорогожицька, 9. https://orcid.org/0000-0002-1872-6948.

Іванько Олександр Вікторович - к.мед.н., дои., директор КНП «Київська міська клінічна лікарня №1», дои. каб. хірургї, анестезіологї̈ та інтенсивної терапії Інституту післядипломної освіти НМУ імені О.О. Богомольия, дои. каф. хірургічних хвороб №1 ПВНЗ «Київський медичний університет», заслужений тікар України. Адреса: м. Київ, Харківське шосе, 121. https://orcid.org/0000-0003-0036-4675.

Борис Руслан Миколайович - д.мед.н., проф. каф. хірургічних хвороб №1 ПВНЗ «Київський медичний університет». Адреса: м. Київ, вул. Дорогожицька, 9. https://orcid.org/0000-0002-2489-8682.

Дар Ясін Ахмед - дисертант каф. хірургічних хвороб №1 ПВНЗ «Київський медичний університет». Адреса: м. Київ, Харківське шосе, 121. htтрs://огсіd. org/0000-0002-2353-238X.

Лисиия Василь Вікторович - асистент каф. хірургічних хвороб №1 ПВНЗ. «Київський медичний університет». Адреса: м. Київ, Харківське шосе, 121. https://orcid.org/0000-0001-5995-7251. 


\title{
В.В. Скиба ${ }^{1,2,3}$, О.В. Іванько ${ }^{1,2,3}$, Н.В. Войтюк ${ }^{1,2,3}$, В.В. Лисиця ${ }^{2,3}$, М.А. Косюк ${ }^{2,3}$, I.O. Корчемний ${ }^{2,3}$ \\ Післяопераційний стан пацієнтів у результаті лікування пахових гриж лапароскопічним та відкритим методами
}

\author{
${ }^{1}$ Національний медччний університет імені О.О. Богомольия, м. Київ, Украйна \\ ${ }^{2}$ ПВНЗ «Київський медичний університет», Україна \\ ${ }^{3}$ КНП «Київська міська клінічна лікарня № 1», Україна
}

Paediatric surgery.Ukraine.2021.3(72):30-35; doi 10.15574/PS.2021.72.30

For citation: Skyba VV, Ivanko AV, Voytyuk NV, Lysytsia VV et al. (2021). Postoperative condition of patients as a result of treatment of inguinal hernias by laparoscopic and open methods. Paediatric Surgery.Ukraine. 3(72):30-35; doi 10.15574/PS.2021.72.30.

Мета - проаналізувати стан пацієнтів після оперативного лікування пахових гриж лапароскопічним та відкритим методами.

Матеріали та методи. Проведено ретроспективний огляд історій хвороби та амбулаторних карт пацієнтів, які перенесли пластику пахової грижі в Київській міській клінічній лікарні № 13 січня 2018 року по липень 2020 року.

Результати. Відкриту герніопластику виконано 86 пацієнтам, лапароскопічну - 138 особам. При відкритій герніопластиці середня тривалість оперативного лікування становила $40 \pm 12$ хв, при лапароскопічній $-35 \pm 12$ хв. Тривалість перебування в стаціонарі була значно довшою в групі пацієнтів, яким проведено відкриту герніопластику ( $48 \pm 12$ год), ніж у групі лапароскопічної пластики (12 3 год).

3 групи пацієнтів, яким проведено відкриту герніопластику, скаржилися на тривалий больовий синдром 62 пацієнти, з групи лапароскопії - 12 хворих. Косметичним виглядом не задоволені 34 пацієнти з групи, в якій пластику проведено відкритим методом, та лише 2 пацієнти з групи лапароскопічної пластики.

Післяопераційні ускладнення спостерігалися у 34 пацієнтів, яким оперативне втручання виконано відкритим методом, та у 15 пацієнтів - за допомогою лапароскопії.

Висновки. Лапароскопічний підхід пластики пахової грижі перевершує герніоплатику відкритим методом, оскільки дає змогу скоротити тривалість перебування у стаціонарі та період післяопераційного відновлення, поліпшити естетичний ефект операції, зменшити частоту інфікування розрізів. За результатами дослідження, така методика дає кращий результат у ранньому післяопераційному періоді, менший відсоток виникнення хронічного болю і вищий ступінь задоволеності пацієнтів порівняно $з$ герніопластикою відкритим методом, із такою ж низькою частотою рецидивів захворювання. Тому лапароскопічна герніопластика $є$ оптимальним методом лікування і може бути рекомендована як метод вибору хірургії пахових гриж.

Дослідження виконано відповідно до принципів Гельсінської декларації. Протокол дослідження ухвалено Локальним етичним комітетом всіх зазначених у роботі установ. На проведення досліджень було отримано інформовану згоду пацієнтів.

Автори заявляють про відсутність конфлікту інтересів.

Ключові слова: пахова грижа, лапароскопія, операція відкритим доступом, аналіз методів, операція. 


\section{Postoperative condition of patients as a result of treatment of inguinal hernias by laparoscopic and open methods}

V.V. Skyba $a^{1,2,3}$, A.V. Ivanko $0^{1,2,3}$, N.V. Voytyuk ${ }^{1,2,3}$, V.V. Lysytsia ${ }^{2,3}$, M.A. Kosyk ${ }^{2,3}$, I.O. Korchemnyy ${ }^{2,3}$

${ }^{1}$ Bogomolets National Medical University, Kyiv, Ukraine,

${ }^{2}$ Kyiv Medical University, Ukraine,

${ }^{3}$ Kyiv City Clinical Hospital No. 1, Ukraine

Purpose - to analyze condition of patients after surgical treatment of inguinal hernias by laparoscopic and open methods.

Materials and methods. A retrospective review of medical histories and outpatient charts of all patients who underwent inguinal hernia surgery at the Kyiv City Clinical Hospital No. 1 from January 2018 to July 2020 was conducted.

Results. During the above period of time in our hospital open hernioplasty was performed in 86 patients, laparoscopic hernioplasty - 138 patients. With open hernioplasty, the average duration of surgical treatment was $40 \pm 12$ minutes. The laparoscopic technique was $35 \pm 12$ minutes. The length of hospital stay was significantly longer in the group of patients with the open method ( $48 \pm 12$ hours) than in the group of laparoscopic plastic surgery ( $12 \pm 3$ hours).

From the group of patients who underwent open hernioplasty, 62 patients complained of long-term pain syndrome, from the group of laparoscopy - 12 patients. The cosmetic appearance was dissatisfied with 34 patients in the open access group and only 2 patients in the laparoscopic plastic group.

Postoperative complications were observed in 34 patients who underwent surgical treatment through open access, and in 15 patients - by laparoscopy.

Conclusions. The laparoscopic approach of inguinal hernia surgery is superior to open access, as it reduces the length of hospital stay, postoperative recovery, improves the aesthetic effect of the operation, reduces the frequency of infection of incisions. According to the results of the study, this technique gives a better result in the early postoperative period, a lower percentage of chronic pain and a higher degree of patient satisfaction compared to open access with the same low recurrence rate. Therefore, in our opinion, laparoscopic access to hernioplasty is the optimal method of treatment and can be recommended as a method of choosing inguinal hernia surgery.

Postoperative assessment of the quality of life of patients after treatment of inguinal hernia by laparoscopic and open methods.

The research was carried out in accordance with the principles of the Helsinki declaration. The study protocol was approved by the Local ethics committee of all participating institution. The informed consent of the patient was obtained for conducting the studies.

No conflict of interest was declared by the authors.

Key words: inguinal hernia, laparoscopy, open access surgery, analysis of methods, operation.

\section{Послеоперационное состояние пациентов в результате лечения паховых грыж лапароскопическим и открытым методами}

В.В. Скиба ${ }^{1,2,3}$, А.В. Иванько ${ }^{1,2,3}$, Н.В. Войтюк ${ }^{1,2,3}$, В.В. Лисица ${ }^{2,3}$, М.А. Косюк ${ }^{2,3}$, И.О. Корчемный ${ }^{2,3}$

${ }^{1}$ Национальный медицинский университет имени А.А. Богомольца, г. Киев, Украина

гчвуз "Киевский медицинский университет», Украина

${ }^{3}$ КНП «Киевская областная клиническая больница № 1», Украина

Цель - проанализировать состояние пациентов после оперативного лечения паховых грыж лапароскопическим и открытым методами.

Материалы и методы. Проведен ретроспективный обзор историй болезни и амбулаторных карт пациентов, перенесших пластику паховой грыжи в Киевской городской клинической больнице № 1 с января 2018 года по июль 2020 года.

Результаты. Открытая герниопластика выполнена 86 пациентам, лапароскопическая - 138 лицам. При открытой герниопластике средняя продолжительность оперативного лечения составила $40 \pm 12$ мин, при лапароскопической $-35 \pm 12$ мин. Продолжительность пребывания в

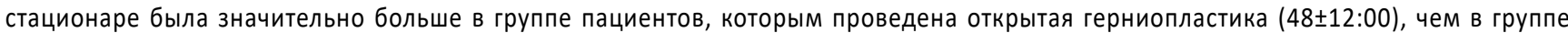
лапароскопической пластики (12 $\pm 3: 00)$.

Из группы пациентов, которым проведена открытая герниопластика, жаловались на длительный болевой синдром 62 пациента, из группь лапароскопии - 12 больных. Косметическим видом были недовольны 34 пациента из группы, в которой пластика проведена открытым методом, и только 2 пациента из группы лапароскопической пластики.

Послеоперационные осложнения наблюдались у 34 пациентов, которым оперативное вмешательство проведено открытым методом, и у 15 пациентов-с помощью лапароскопии.

Выводы. Лапароскопический подход пластики паховой грыжи превосходит герниопластику открытым методом, поскольку позволяет сократить время пребывания в стационаре, период послеоперационного восстановления, улучшить эстетический эффект операции, уменьшить частоту инфицирования разрезов. По результатам исследования, данная методика дает лучший результат в раннем послеоперационном периоде, меньший процент возникновения хронической боли и более высокую степень удовлетворенности пациентов по сравнению с оперативным вмешательством путем открытого доступа, с такой же низкой частотой рецидивов заболевания. Поэтому лапароскопическая герниопластика является оптимальным методом лечения и может быть рекомендована в качестве метода выбора хирургии паховых грыж.

Исследование выполнено в соответствии с принципами Хельсинкской декларации. Протокол исследования одобрен Локальным этическим комитетом участвующего учреждения. На проведение исследований получено информированное согласие пациентов.

Авторы заявляют об отсутствии конфликта интересов.

Ключевые слова: паховая грыжа, лапароскопия, операция в открытом доступе, разбор методов, операция.

\section{Вступ}

Пахова грижа статистично $€$ найпоширенішою серед усіх гриж черевної порожнини. Частота виникнення випинання внутрішніх органів або жирової тканини через паховий канал становить $27-43 \%$ у чоловіків і 3-6\% у жінок [7]. До факторів ризику розвитку пахової грижі можна віднести сімейний анамнез, стать, вік, аномальний метаболізм колагену, простатектомію в анамнезі та низький індекс маси тіла. Пахові грижі зазвичай симптоматичні й клінічно проявляються опуклістю в ділянці паху та больовими відчуттями [2]. Опуклість живота може 
зникнути при переході пацієнта в лежаче положення. Часто такі грижі призводять до запалення, порушення процесу сечовипускання і навіть до розвитку кишкової непрохідності. Діагностика цього захворювання не складна і полягає в зборі анамнезу та об’єктивному огляді. У рідкісних випадках встановлення правильного діагнозу потребує додаткових інструментальних методів обстеження (ультразвукове дослідження, магнітно-резонансна томографія, герніографія тощо).

У світі пластика пахової грижі - одна з найпоширеніших операцій, яку щорічно проводять понад 20 млн осіб. Оперативне лікування виконують для усунення симптомів захворювання і також для запобігання ускладненням, таким як кишкова непрохідність. Хірургія пахових гриж здебільшого є успішною, проте рецидиви захворювання потребують повторних операцій у 10-15\% випадків. А тривала втрата працездатності через хронічний біль (тривалістю понад 3 міс) зустрічається у 10-12\% пацієнтів. Приблизно 1-3\% пацієнтів відчувають сильний хронічний біль [7].

Перші операції з видалення пахової грижі проведені ще наприкінці XVI століття. Особливість техніки проведення маніпуляції полягала в зменшенні та резекції грижового мішка, зміцненні задньої стінки пахового каналу шляхом зближення його м'язового і фасціального компонентів. Згодом запропоновані й інші (новіші) варіанти пластики пахового каналу. Сучасні методи оперативного втручання при пахових грижах полягають у використанні протезного матеріалу. Уперше його почали застосовувати ще в 1960-х роках, спочатку тільки в пацієнтів літнього віку із рецидивними паховими грижами. Сприятливі довгострокові результати цієї методики стимулювали впровадження пластики сітки в молодших пацієнтів. У цей час більшість хірургів у світі надають перевагу пластиці пахових гриж сіткою. На початку 1980-х років уперше виконані мініінвазивні методи пластики пахової грижі. Також розроблені лапароскопічні, трансабдомінальні, преперитонеальні і повністю екстраперитонеальні ендоскопічні методи. У поєднанні такі способи називали «лапаро-ендоскопічною хірургією».

Той факт, що зараз виконується так багато різних методів герніопластики, переконливо свідчить про те, що «найкращого методу» пластики пахового каналу не існує. Тому лікування пахової грижі не є стандартизованим. Пахові грижі можна лікувати за допомогою методів накладення швів або сітки, за допомогою переднього або заднього доступу, а також за допомогою відкритої хірургії або лапаро-ендоскопічним шляхом. Мінімальну інвазивність процедури завжди ви- конують із заднього доступу та з використанням сітки. Відкриті операції з накладанням швів виконують класичним переднім доступом. Добре відомими методами накладення швів є методи Бассіні, Шоулдіса і Десарда. А стандартна техніка на основі сітки через передній доступ - це метод Ліхтенштейна.

Традиційна відкрита герніотомія в дітей та дорослих, що застосовується протягом багатьох десятків років, вирізняється простотою операції і високою популярністю. Деякі вчені вважають, що слід відкрити паховий канал, щоб не пошкодити судини і сім'явивідну протоку [12]. Відкрите відновлення пахового каналу дає змогу проводити локально-регіонарну (місцеву) анестезію, оскільки тривале загальне знеболювання, особливо у хворих на серцево-судинні захворювання та літніх людей, пов'язане з ризиком негативних наслідків (зупинка дихання тощо). Серед переваг лапароскопічної герніопластики можна виділити наявність прихованого рубця, мінімальну інвазивність процедури та здатність краще виявляти контрлатеральний вагінальний відросток. У дітей за герніорафії методом PIRS (percutaneous internal ring suturing, черезшкірне ушивання внутрішнього кільця) - взагалі нічого, окрім місця уколу голки, не візуалізується. Також у дитячій практиці використовують інші лапароскопічні методики [9]. У 2016 р. Міжнародна група педіатричних ендохірургів провела огляд усіх наявних даних про підходи до лікування пахових гриж у дітей 3 мінімальним доступом і дійшла висновку, що лапароскопічна пластика пахового каналу дає змогу скоротити тривалість операції, а також зменшити кількість післяопераційних ускладнень порівняно 3 оперативним втручанням шляхом відкритого доступу [4]. Але при лапароскопічній герніопластиці спостерігається тенденція до збільшення частоти рецидивів. У своєму дослідженні O’Reilly зі співавторами не виявили жодних недоліків трансабдомінального доступу при оперативному лікуванні пахових гриж із точки зору частоти рецидивів. А лапароскопічні методи перевершували відкриті лише щодо виникнення хронічного післяопераційного болю [8]. Як згадувалося вище, одне дослідження виявило значно меншу частоту хронічного болю після трансабдомінального доступу, ніж після пластики за Ліхтенштейном. Науковці зазначили, що група пацієнтів із підвищеним ризиком післяопераційного болю була ідентифікована до операції за їхньою реакцією на стандартизований больовий подразник. Автори дійшли висновку, що пацієнтам цієї групи слід робити лапароскопічне, а не відкрите хірургічне втручання з приводу пахової грижі [1]. 
Оригінальні дослідження. Абдомінальна хірургія

Питання пахових гриж у жінок заслуговує на особливу увагу. Аналіз даних датського реєстру показав, що рецидив пахових гриж виникає в жінок, яким раніше проводили герніопластику через відкритий передній доступ. Більш ранній аналіз з датської бази даних щодо гриж показав, що лапароскопічна хірургія в жінок є методом вибору через високу частоту рецидивів після пластики за Ліхтенштейном [3].

Рецидивна пахова грижа - ще один особливий випадок, який слід детальніше розглянути. Успішність герніопластики залежить від типу початкової операції, тривалості їі проведення та розмірів випинання. Однак найголовнішим критерієм вважається метод хірургічного втручання. Наприклад, рубець передньої пахової стінки після операції з використанням переднього доступу робить задній доступ кращим для повторної операції, і навпаки. Дослідження, проведене в шведському реєстрі, показало значно нижчу частоту повторних рецидивів захворювання в разі лапароскопічного доступу після попередньої операції на передньому відділі, ніж при повторному відкритому передньому доступі [10]. Однак після попередньої операції на задніх відділах повторний лапароскопічний задній доступ показав ті самі результати, що і передній доступ. Тому європейська спільнота герніопластики вважає лапароскопічні операції при рецидивах методом вибору після попередньої операції через передній доступ [11].

Отже, досі ведуться суперечки щодо найкращої стратегії оперативного лікування пахових гриж через відсутність вирішальних доказів переваги однієї зі стратегій лікування. Стандартизація пластики пахової грижі і поліпшення результатів вимагає відповідей на багато питань. В літературі зустрічається кілька систематичних оглядів, які порівнюють лапароскопічний доступ оперативного лікування пахових гриж із відкритими методами, однак достатній рівень доказовості цих досліджень вельми обмежений $[5,6]$. Кращі оперативні методи повинні відповідати таким характеристикам: низька частота ускладнень, простота техніки виконання операції, швидке відновлення пацієнта, короткий післяопераційний період та економічна ефективність.

Мета дослідження - проаналізувати стан пацієнтів після оперативного лікування пахових гриж лапароскопічним та відкритим методами.

\section{Матеріали та методи дослідження}

Проведено ретроспективний огляд історій хвороби та амбулаторних карт пацієнтів, які перенесли пластику пахової грижі в Київській міській
Таблиця

Статево-вікова характеристика пацієнтів обох груп

\begin{tabular}{|l|l|l|}
\hline Критерій & $\begin{array}{l}\text { Відкрита } \\
\text { герніопластика }\end{array}$ & $\begin{array}{l}\text { Лапароскопічна } \\
\text { герніопластика }\end{array}$ \\
\hline $\begin{array}{l}\text { Стать } \\
\text { чоловіки } \\
\text { жінки }\end{array}$ & 58 & 94 \\
\hline Середній вік & 43 & 44 \\
\hline $\begin{array}{l}\text { Загальна } \\
\text { кількість }\end{array}$ & 86 & 56 \\
\hline
\end{tabular}

клінічній лікарні № 1 з січня 2018 року по липень 2020 року. Отриману інформацію схвалено та узгоджено з адміністрацією лікарні. Пацієнти підписали доопераційну форму інформованої згоди і погодилися на участь у дослідженні. Під час збору даних забезпечено конфіденційність особистої інформації про пацієнтів. Хворим роз'яснено спосіб виконання обох технік хірургічного втручання, зовнішній вигляд розрізу після операції і можливі операційні ускладнення. До дослідження не увійшли випадки защемленої грижі. До критеріїв оцінки стану пацієнтів після оперативного лікування пахових гриж віднесено: наявність післяопераційних ускладнень, вираженість післяопераційного болю, час до повного одужання, частота рецидивів, косметичний зовнішній вигляд післяопераційної ділянки, тривалість операції і госпіталізації. Дані отримано на основі суб'єктивних відчуттів пацієнтів і в результаті аналізу записів у медичній документації. Результати, отримані в ході дослідження, опрацьовано за допомогою методів статистичного спостереження, зведення та групування даних.

\section{Результати дослідження та їх обговорення}

3 січня 2018 року по липень 2020 року в Київській міській клінічній лікарні № 1 успішно виконано 224 операції з приводу пахових гриж. Усіх хворих до операції розподілено на дві групи залежно від вибору методу оперативного втручання. Відкриту пластику пахової грижі виконано 86 пацієнтам, лапароскопічну - 138 пацієнтам. Вік хворих становив від 33 до 66 років. Віко-статеву характеристику пацієнтів обох груп наведено в таблиці.

Усім хворим проведено оперативне лікування грижі пахового каналу під загальним знеболюванням незалежно від методу пластики.

Тривалість операції та госпіталізації в обох групах була різною. У хворих, прооперованих методом відкритої герніопластики, середня тривалість оперативного втручання становила $40 \pm 12 \mathrm{xв}$, а при ла-

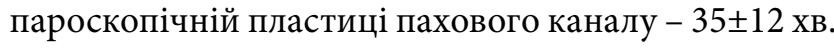




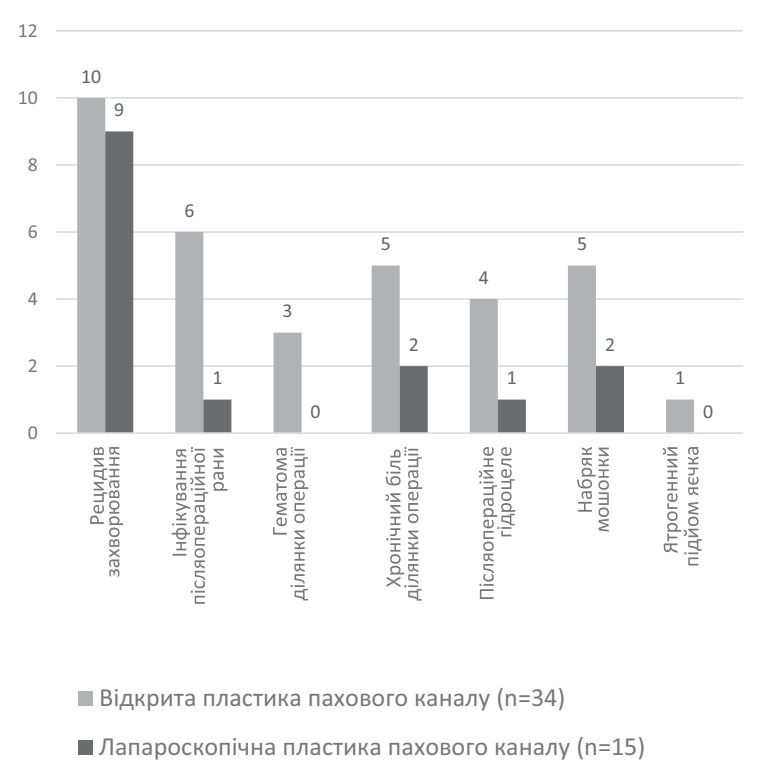

Рис. Частота виникнення післяопераційних ускладнень

Також проаналізовано тривалість перебування хворих у стаціонарі після лапароскопічної пластики пахової грижі порівняно з оперативним втручанням відкритим методом. Тривалість перебування в лікарні була значно довшою в групі пацієнтів, яким проведено відкриту герніопластику ( $48 \pm 12$ год), ніж

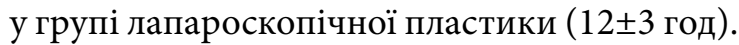

Важливим критерієм оцінки обох методів оперативного лікування $є$ тривалість післяопераційного болю. 3 групи пацієнтів, яким проведено відкриту герніопластику, на тривалий (24-36 год) больовий синдром скаржилися 62 пацієнти. Напрочуд, на біль у ділянці післяопераційної рани скаржилися лише 12 хворих із групи, в якій оперативне лікування виконано лапароскопічним методом. На стан пацієнтів впливав також і зовнішній вигляд післяопераційної ділянки. Серед групи з відкритим доступом герніопластики косметичним виглядом пахової ділянки були незадоволені 34 пацієнти. На відміну від групи пацієнтів лапароскопічної пластики, в якій незадоволення стосовно стану післяопераційної зони висловили лише 2 пацієнти. Слід зазначити, що усі хворі, незадоволені косметичним виглядом пахової ділянки, були жіночої статі, середній вік яких становив $37 \pm 4$ роки.

Частота рецидивів захворювання та післяопераційних ускладнень у групах із відкритою та лапароскопічною герніопластикою наведена на рис. Післяопераційні ускладнення спостерігалися у 34 пацієнтів, яким оперативне лікування проведено через відкритий доступ, та в 15 пацієнтів - за допомогою лапароскопії. У цьому дослідженні не виявлено значущої різниці в частоті рецидивів грижі між групами. Однак відсоток інфікування ділянки хірургічного втручання в групі, в якій проведено відкрите оперативне втручання, був значно вищим порівняно з групою лапароскопічної хірургії. Розвиток хронічного болю в ділянці післяопераційної рани в групі з відкритою герніопластикою був вищим порівняно з групою з лапароскопічним доступом. На наступну добу після оперативного лікування у 3 пацієнтів, яким проведено відкриту герніопластику, спостерігалася післяопераційна гематома. При лапароскопічній пластиці пахового каналу це ускладнення не спостерігалося.

Певні додаткові ускладнення відмічалися в пацієнтів чоловічої статті - набряк мошонки, післяопераційне гідроцеле та ятрогенний підйом яєчка. Частота набряку мошонки та післяопераційного гідроцеле в групі відкритої пластики була значно вищою, ніж при лапароскопічній хірургії, а різниця між ними - статистично значущою. Післяопераційний ятрогенний підйом яєчка спостерігався тільки в 1 випадку в групі, в якій оперативне лікування проведено відкритим методом.

\section{Висновки}

Зі швидким розвитком ендоскопічної технології лапароскопічний метод отримав широке визнання в хірургії пахових гриж, оскільки дає змогу зменшити очевидний розріз шкіри порівняно з відкритим оперативним втручанням і поліпшити косметичний ефект операції. У цьому дослідженні пацієнти не скаржилися на косметичний вигляд післяопераційної ділянки в групі лапароскопічної герніопластики, оскільки розрізи були невеликих розмірів, а основний рубець був прихований пупком.

За отриманими результатами, тривалість операції у хворих обох груп незначно різнилася. Не виявлено статистично значущих відмінностей у частоті рецидивів між лапароскопічною і відкритою пластикою пахової грижі. Однак частота інфікування розрізів при лапароскопічному доступі була набагато нижчою, а тривалість госпіталізації - набагато коротшою, ніж при відкритому хірургічному втручанні. Слід зазначити, що при лапароскопічній пластиці пахової грижі спостерігалася менша кількість ускладнень, таких як гематома, хронічний біль ділянки операції, післяопераційне гідроцеле та набряк мошонки, а ятрогенний підйом яєчка взагалі не відмічався.

Лапароскопічний підхід пластики пахової грижі перевершує відкриту герніопластику за деякими параметрами, включаючи частоту інфікування розрізів і тривалість перебування в стаціонарі. За ре- 


\section{Оригінальні дослідження. Абдомінальна хірургія}

зультатами дослідження, така методика дає кращий результат у ранньому післяопераційному періоді, менший відсоток виникнення хронічного болю і вищий ступінь задоволеності пацієнтів порівняно з відкритим доступом із такою ж низькою частотою рецидивів захворювання. Тому, лапароскопічна герніопластика $є$ оптимальним методом лікування і може бути рекомендована як метод вибору хірургії пахових гриж.

Автори заявляють про відсутність конблікту інтересів.

\section{References/Лiтература}

1. Aasvang EK, Gmahle E, Hansen JB et al. (2010). Predictive risk factors for persistent postherniotomy pain. Anesthesiology. 112: 957-969.

2. Bergman S, Feldman L. (2009). 28 Inguinal hernia repair. In: ACS Surgery: Principles and Practice. BC Decker Inc: 1-22.

3. Burcharth J, Andresen K, Pommergaard HC, Bisgaard T, Rosenberg J. (2014). Direct inguinal hernias and anterior surgical approach are risk factors for female inguinal hernia recurrences. Langenbecks Arch Surg. 399: 71-76.

4. Davies DA, Rideout DA, Clarke SA. (2020). The international pediatric endosurgery group evidence-based guideline on minimal access approaches to the operative management of inguinal hernia in children. J Laparoendosc \& Adv Surg Tech. 30 (2): 221-227.

5. Esposito C, St Peter SD, Escolino M, Juang D, Settimi A, Holcomb GW. (2014). Laparoscopic versus open inguinal hernia repair in pediatric patients: a systematic review. J Laparoendosc Adv Surg Tech A. 24: 811-818.

6. Feng S, Zhao L, Liao Z, Chen X. (2015). Open versus laparoscopic inguinal herniotomy in children: a systematic review and meta-analysis focusing on postoperative complications. Surg Laparosc Endosc Percutan Tech. 25: 275-280.

7. Kingsnorth A, LeBlanc K. (2003, Nov 8). Hernias: inguinal and incisional. Lancet. 362 (9395): 1561-1571. doi: 10.1016/S01406736(03)14746-0.

8. O'Reilly EA, Burke JP, O'Connell PR. (2012). A meta-analysis of surgical morbidity and recurrence after laparoscopic and open repair of primary unilateral inguinal hernia. Ann Surg. 255: 846-853.

9. Rusak P, Rybalchenko V, Akmolaev D, Zaremba V, Shevchuk D, Stefanishin M. (2011). Endoscopic treatment of inguinal hernias in children. Surgery of Ukraine. 3 ((39)1): 4-5.

10. Sevonius D, Gunnarsson U, Nordin P, Nilsson E, Sandblom G. (2011). Recurrent groin hernia surgery. Br J Surg. 98: 1489-1494.

11. Zannoni M, Luzietti E, Viani L, Nisi P, Caramatti C, Sianesi M. (2014). Wide resection of inguinal nerves versus simple section to prevent postoperative pain after prosthetic inguinal hernioplasty: our experience. World J Surg. 38: 1037-1043.

12. Zhou X, Qi X, Jiang B, Sha Y, Song D. (2017). Transumbilical endoscopic technique for complete closure of inguinal hernias in female pediatric patients. Exp Ther Med. 13 (1): 41-44.

\footnotetext{
Відомості про авторів: https://orcid.org/0000-0002-7681-4217. https://orcid.org/0000-0002-3901-6777.

Стаття надійшла до редакції 11.04.2021 р., прийнята до друку 8.09.2021 p.
}

Скиба Володимир Вікторович - д.мед.н., академік АНВШ, проф., директор «Центру хірургї» КНП «Київська міська клінічна лікарня №1», зав. каф. хірургічних хвороб № 1 ПВНЗ «Київський медичний університет», зав. каб. хірургії, анестезіології та інтенсивної терапї ІПФ НМУ імені О.О. Богомольия, засл. діяч науки і техніки України, Лауреат державної премії України в галузі науки і техніки. Адреса: м. Київ, Харківське шосе, 121.

Іванько Олександр Вікторович - к.мед.н., дои., директор КНП «Київська міська клінічна лікарня №1», дои. каф. хірургї, анестезіологї та інтенсивної терапії Інституту післядипломної освіти НМУ імені О.О. Богомольия, дои. каб. хірургічних хвороб № 1 ПвНЗ «Київський медичний університет», заслужений лікар України. Адреса: м. Київ, Харківське шосе, 121. https://orcid.org/0000-0003-0036-4675.

Войтюк Наталя Вікторівна - асистетнт каф. хірургї, анестезіології та інтенсивної терапї Інституту післядипломної освіти НмУ імені О.О. Богомольия. Адреса: м. Київ, Харківське шосе, 121. https://orcid.org/0000-0002-6821-1707.

Косюк Максим Анатолійович - асистент каф. хірургії №1 ПВНЗ «Київський медичний університет». Адреса: м. Київ, Харківське шосе, 121.

Лисиия Василій Вікторович - асистент каф. хірургї №1 ПвНЗ «Київський медичний університет». Адреса: м. Київ, Харківське шосе, 121.

Кориемний Іван Олександрович - ст. лаборант каф. хірургї №1 ПВНЗ «Київський медичний університет». Адреса: м. Київ, Харківське шосе, 121. 


\title{
Р.А. Наконечний, А.Й. Наконечний
}

\section{Цистоскопічні особливості вічок сечоводів у дітей з міхурово-сечовідним рефлюксом}

\author{
Львівський національний медичний університет імені Данила Галицького, Украйна
}

Paediatric surgery.Ukraine.2021.3(72):36-42; doi 10.15574/PS.2021.72.36

For citation: Nakonechnyy RA, Nakonechnyi AY. (2021). Cystoscopic features of the ureteral orifices in children with vesicoureteral reflux. Paediatric Surgery. Ukraine. 3(72):36-42; doi 10.15574/PS.2021.72.36.

Мета - встановити цистоскопічні прогностичні критерії міхурово-сечовідного рефлюксу (MCР) у дітей.

Матеріали та методи. Клінічний матеріал охоплює 270 хворих на MCP II-IV ст. віком від 9 місяців до 14 років та 22 практично здорові дитини. До обстеження залучали хворих на МСР у період клініко-лабораторної ремісії без клінічних симптомів нейрогенного сечового міхура. Під час цистоскопії оцінювали стан слизової сечового міхура; розташування, форму, ступінь гідродилатації і скоротливу здатність вічок сечоводів.

Результати. У хворих на МСР діагностувалися вічка сечоводів у формі: підкови - 127 (47,04\%) пацієнтів, стадіону - 106 (39,26\%), ямки для гольфа - 37 (13,7\%). Вони були в зонах: А - 13 (4,81\%) дітей, В - 154 (57,04\%), C - 67 (24,81\%), D - 36 (13,33\%), а також характеризувалися ступенем гідродилатації: Н0 - 7 (2,59\%) хворих, H1 - 173 (64,07\%), Н2 - 60 (22,22\%), Н3 - 30 (11,11\%). При МСР однозначно переважала в'яла перистальтика вічок сечоводів - 252 (93,33\%) випадки, щодо активної перистальтики лише у 18 (6,67\%) пацієнтів.

Висновки. Для вічок сечоводів у формі стадіону і з більш вираженими ознаками глибочіння, які зміщені в зону В і латеральніше на бокову стінку сечового міхура, зі ступенем гідродилатації понад Н1, притаманна позитивна асоціація щодо МСР за найвищої специфічності тестів.

Несприятливими прогностичними діагностичними маркерами для ефективних мініінвазивних втручань у хворих на МСР слід вважати вічка сечоводів, у яких поєднуються такі морфотопографічні характеристики, як виражені ознаки глибочіння до форми ямки для гольфа, латералізація на бокову стінку сечового міхура в зону D і гідродилатація Н3 ступеня.

Дослідження виконано відповідно до принципів Гельсінської декларації. Протокол дослідження ухвалено Локальним етичним комітетом зазначеної в роботі установи. На проведення досліджень отримано інформовану згоду батьків дітей.

Автори заявляють про відсутність конфлікту інтересів.

Ключові слова: міхурово-сечовідний рефлюкс, вічко сечоводу, цистоскопія, діти.

\section{Cystoscopic features of the ureteral orifices in children with vesicoureteral reflux}

\section{R.A. Nakonechnyy, A.Y. Nakonechnyi}

\section{Danylo Halytsky Lviv National Medical University, Ukraine}

Purpose - to establish cystoscopic prognostic criteria for vesicoureteral reflux (VUR) in children.

Materials and methods. Clinical material covers 270 patients with VUR II-IV grades aged 9 months to 14 years and 22 healthy children. The study included patients with VUR in the period of clinical and laboratory remission without symptoms of neurogenic bladder. During cystoscopy, the condition of the bladder mucosa was assessed; location, shape, hydrodistention degree, and ureteral orifices contractility.

Results. Patients with VUR were diagnosed ureteral orifices in the form of: horseshoes - 127 (47.04\%) patients, stadium - 106 (39.26\%) and golf holes 37 (13.7\%). They were in the zones: A-13 (4.81\%) children, B - 154 (57.04\%), C - 67 (24.81\%), D - 36 (13.33\%), and were characterized by the hydrodistention degree: $\mathrm{HO}-7$ (2.59\%) patients, $\mathrm{H} 1-173(64.07 \%), \mathrm{H} 2-60$ (22.22\%) and $\mathrm{H} 3-30$ (11.11\%). In children with VUR, sluggish peristalsis of the ureter orifices clearly prevailed $-252(93.33 \%)$ cases, relative to active peristalsis in only $18(6.67 \%)$ patients.

Conclusions. For ureteral orifices in the form of a stadium and with more pronounced signs of deepening, which are shifted to zone B and laterally to the sidewall of the bladder, with a hydrodistention degree above $\mathrm{H} 1$ has a positive association with VUR at the highest specificity of tests.

Unfavorable prognostic diagnostic markers for effective minimally invasive interventions in patients with VUR should be considered ureteral orifices, which combine such morpho-topographic characteristics as pronounced signs of deepening to the shape of a golf hole, lateralization to the sidewall of the bladder in zone $\mathrm{D}$, and hydrodistention $\mathrm{H} 3$ degree. 
The research was carried out in accordance with the principles of the Helsinki declaration. The study protocol was approved by the Local ethics committee of all participating institution. The informed consent of the patient was obtained for conducting the studies.

No conflict of interest was declared by the authors.

Key words: vesicoureteral reflux, ureteral orifice, cystoscopy, children.

Цистоскопические особенности устьев мочеточников у детей с пузырно-мочеточниковым рефлюксом Р.А. Наконечный, А.И. Наконечный

Львовский национальный медицинский университет имени Данила Галицкого, Украина

Цель-установить цистоскопические прогностические критерии пузырно-мочеточникового рефлюкса (ПМР) у детей.

Материалы и методы. Клинический материал охватывает 270 больных ПMP II-IV ст. в возрасте от 9 месяцев до 14 лет и 22 практически здоровых ребенка. В обследования включали больных ПМР в период клинико-лабораторной ремиссии без клинических симптомов нейрогенного мочевого пузыря. Во время цистоскопии оценивали состояние слизистой мочевого пузыря; расположение, форму, степень гидродилатации и сократительную способность устьев мочеточников.

Результаты. У больных ПМР диагностированы устья мочеточников в форме: подковы - 127 (47,04\%) пациентов, стадиона - 106 (39,26\%), ямки для гольфа - 37 (13,7\%). Они были в зонах: A - 13 (4,81\%) детей, B - 154 (57,04\%), C- 67 (24,81\%), D - 36 (13,33\%), а также характеризовались степенью гидродилатации: НО - 7 (2,59\%) больных, Н1 - 173 (64,07\%), Н2 - 60 (22,22\%), Н3 - 30 (11,11\%). При ПМР однозначно преобладала дряблая перистальтика устьев мочеточников - 252 (93,33\%) случая, в отношении к активной перистальтике только у 18 (6,67\%) пациентов.

Выводы. Для устьев мочеточников в форме стадиона и с более выраженными признаками зияния, которые смещены в зону В и латеральнее на боковую стенку мочевого пузыря, со степенью гидродилатации более Н1 присуща положительная ассоциация с ПМР при высокой специфичности тестов.

Неблагоприятными прогностическими диагностическими маркерами для эффективных миниинвазивных вмешательств у больных ПМР следует считать устья мочеточников, в которых сочетаются такие морфотопографические характеристики, как выраженные признаки зияния в форме ямки для гольфа, латерализация на боковую стенку мочевого пузыря в зону D и гидродилатация Н3 степени.

Исследование выполнено в соответствии с принципами Хельсинкской декларации. Протокол исследования одобрен Локальным этическим комитетом всех участвующих учреждений. На проведение исследований получено информированное согласие родителей детей.

Авторы заявляют об отсутствии конфликта интересов.

Ключевые слова: пузырно-мочеточниковый рефлюкс, устье мочеточника, цистоскопия, дети.

\section{Вступ}

Хоча про міхурово-сечовідний рефлюкс (МСР) відомо з кінця XIX ст., однак тільки останніми роками клінічна важливість цієї проблеми стала очевидною. MCР $\epsilon$ найпоширенішою аномалією сечовивідних шляхів у популяції. Він зустрічається приблизно в $0,4-1,8 \%$ дітей $[2,4,14,16]$. У дітей з МСР прогресуюче ураження нирок із формуванням нефросклерозу аж до розвитку хронічної ниркової недостатності (ХHH), яка потребує замісної терапії і в подальшому трансплантації нирок, є однією з актуальних проблем [1].

Ще одна проблема, яка на сьогодні не втрачає актуальності, - це своєчасна діагностика МСР і функціонального стану паренхіми нирок у дітей. Удосконалення променевих методів досліджень останніми роками значно поліпшило діагностику урологічних захворювань у дітей усіх вікових груп. Для встановлення діагнозу МСР і обрання оптимального способу лікування, а також для динамічного моніторингу за клінічним перебігом вади традиційно використовують лабораторне, ультразвукове, рентгенологічне, радіонуклідне та ендоскопічне дослідження $[12,13]$.

Цистоуретроскопія дає багато корисної інформації. Зокрема, можна вивчити морфотопографічну характеристику вічок сечоводів, виявити повне подвоєння сечових шляхів чи розміщення дивертикулів сечового міхура стосовно вічок, уточнити уретральну прохідність тощо. Проте, незважаючи на позитивні сторони цистоскопічного обстеження, його не слід декларувати як обов'язкове дослідження в пацієнтів з МСР $[5,15]$.
Чим більше змінений зовнішній вигляд вічка сечоводу, тим далі від шийки сечового міхура воно лежить. Зміщення вічка сечоводу на бокову стінку відображає ступінь недостатності сечоміхурового трикутника. Крім цього, аномальне вічко сечоводу характеризується м'язовою неповноцінністю $[3,8,15]$.

Відповідно до позиції уретеральних вічок сечоводів розрізняють такі класичні зони іх розміщення: А нормальна, B - помірна, C - виражена латералізація на бокову стінку сечового міхура [8]. Максимальну латералізацію вічка сечоводу інтерпретують як зону D [3] .

Форма і розміщення вічка сечоводу корелюють з довжиною внутрішньоміхурової частини сечоводу. Якщо вічко сечоводу розташоване латеральніше від шийки сечового міхура, то це свідчить про короткий інтрамуральний відділ сечоводу та його погане прикріплення до сечоміхурового трикутника. Саме зміщення вічка сечоводу на бокову стінку відображає ступінь недостатності сечоміхурового трикутника. Такі вічка сечоводів асоціюються з більшою ймовірністю виникнення МСР $[3,8,15]$.

На думку J.M. Park (2006), ендоскопічне розміщення вічка сечоводу не вважається особливо надійною клінічною ознакою при низьких і середніх ступенях МСР, однак цистоскопічні знахідки забезпечують розуміння механізму сечовідно-міхурового з'єднання [11].

Гідродилатація вічка сечоводу дає змогу візуалізувати місце інтрауретеральної ін'єкції під час ендоскопічної корекції МСР та оцінити ефективність лікування - адекватне змикання стінок сечоводу. 
Оригінальні дослідження. Урологія та гінекологія

Таблиця 1

Характеристика хворих на міхурово-сечовідний рефлюкс залежно від форми вади

\begin{tabular}{|c|c|c|c|c|c|}
\hline \multirow{2}{*}{ MCP } & \multicolumn{4}{|c|}{ Вікова підгрупа, роки } & \multirow{2}{*}{ Усboro } \\
\hline & до 1 & від 1 до 3 років & від 3 до 10 років & від 10 & \\
\hline однобічний & $\begin{array}{c}10 \\
3,7 \%\end{array}$ & $\begin{array}{c}60 \\
22,22 \%\end{array}$ & $\begin{array}{c}56 \\
20,74 \%\end{array}$ & $\begin{array}{c}26 \\
9,63 \%\end{array}$ & $\begin{array}{c}152 \\
56,3 \%\end{array}$ \\
\hline $\begin{array}{l}\text { двобічний } \\
\text { /сечоводів }\end{array}$ & $\begin{array}{c}12 \\
4,44 \% \\
/ 24 \\
\end{array}$ & $\begin{array}{c}49 \\
18,15 \% \\
/ 98\end{array}$ & $\begin{array}{c}42 \\
15,56 \% \\
/ 84\end{array}$ & $\begin{array}{c}15 \\
5,56 \% \\
/ 30\end{array}$ & $\begin{array}{c}118 \\
43,7 \% \\
/ 236 \\
\end{array}$ \\
\hline разом & $\begin{array}{c}22 \\
8,15 \% \\
/ 34\end{array}$ & $\begin{array}{c}109 \\
40,37 \% \\
/ 158\end{array}$ & $\begin{array}{c}98 \\
36,3 \% \\
/ 140\end{array}$ & $\begin{array}{c}41 \\
15,19 \% \\
/ 56\end{array}$ & $\begin{array}{c}270 \\
100 \% \\
/ 388\end{array}$ \\
\hline
\end{tabular}

Таблиця 2

Характеристика хворих на міхурово-сечовідний рефлюкс за ступенями у віковому аспекті

\begin{tabular}{|c|c|c|c|c|c|c|c|}
\hline \multirow{2}{*}{\multicolumn{2}{|c|}{ MCP }} & \multicolumn{4}{|c|}{ Вікова підгрупа, роки } & \multirow{2}{*}{\multicolumn{2}{|c|}{ Усьoro }} \\
\hline & & \multirow{2}{*}{$\begin{array}{l}\text { до } 1 \\
3(1,11 \%) \\
\end{array}$} & \multirow{2}{*}{$\begin{array}{l}\text { від } 1 \text { до } 3 \text { років } \\
7(2,59 \%) \\
\end{array}$} & \multirow{2}{*}{$\begin{array}{l}\text { від } 3 \text { до } 10 \text { років } \\
18(6,67 \%)\end{array}$} & \multirow{2}{*}{$\begin{array}{c}\text { від } 10 \text { років } \\
7(2,59 \%)\end{array}$} & & \\
\hline & однобічний & & & & & $35(12,96 \%)$ & \multirow{5}{*}{$270 / 388$} \\
\hline 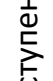 & $\begin{array}{l}\text { двобічний/ } \\
\text { сечоводів }\end{array}$ & $3(1,11 \%) / 6$ & $9(3,33 \%) / 18$ & $20(7,41 \%) / 40$ & $7(2,59 \%) / 14$ & $39(14,44 \%) / 78$ & \\
\hline$=$ & разом & $6(2,22 \%) / 9$ & $16(5,93 \%) / 25$ & $38(14,07 \%) / 58$ & $14(5,19 \%) / 21$ & $74(27,41 \%) / 113$ & \\
\hline \multirow{3}{*}{ 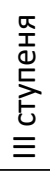 } & однобічний & $4(1,48 \%)$ & $35(12,96 \%)$ & $34(12,59 \%)$ & $15(5,56 \%)$ & $88(32,59 \%)$ & \\
\hline & $\begin{array}{l}\text { двобічний/ } \\
\text { сечоводів }\end{array}$ & $5(1,85 \%) / 10$ & $28(10,37 \%) / 56$ & $16(5,93 \%) / 32$ & $8(2,96 \%) / 16$ & $57(21,11 \%) / 114$ & \\
\hline & разом & $9(3,33 \%) / 14$ & $63(23,33 \%) / 91$ & $50(18,52 \%) / 66$ & $23(8,52 \%) / 31$ & $145(53,7 \%) / 202$ & \multirow{4}{*}{$270 / 388$} \\
\hline \multirow{3}{*}{ 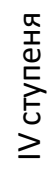 } & однобічний & $3(1,11 \%)$ & $18(6,67 \%)$ & $4(1,48 \%)$ & $4(1,48 \%)$ & $29(10,74 \%)$ & \\
\hline & $\begin{array}{l}\text { двобічний/ } \\
\text { сечоводів }\end{array}$ & $4(1,48 \%) / 8$ & $12(4,44 \%) / 24$ & $6(2,22 \%) / 12$ & $0(0 \%)$ & $22(8,15 \%) / 44$ & \\
\hline & разом & $7(2,59 \%) / 11$ & $30(11,11 \%) / 42$ & $10(3,7 \%) / 16$ & $4(1,48 \%) / 4$ & $51(18,89 \%) / 73$ & \\
\hline
\end{tabular}

Вважають, що в цьому аспекті ступінь гідророзширення вічка сечоводу є важливішим за ступінь МСР. Так, ступінь МСР визначає суправезикальне розширення сечоводу і чашечко-мискової системи, а ступінь гідророзширення вічка сечоводу - еластичність вічка сечоводу, на якому проводиться лікування. Ступінь гідророзширення вічка сечоводу значно коливається в межах кожного ступеня МСР, але прямо корелює з ним. Виділяють чотири ступені гідророзширення вічка сечоводу. Так, ступінь гідророзширення вічка сечоводу: Н0 - немає видимого розширення вічка сечоводу; $\mathrm{H} 1$ - вічко сечоводу відкривається, інтрамуральний тунель не виражений; Н2 - вічко сечоводу відкривається, інтрамуральний тунель чітко візуалізується, сечовід екстрамурально видно не чітко; Н3 - вічко сечоводу відкривається, екстрамурально сечовід добре візуалізується або в сечовід можна зайти цистоскопом. Для визначення ступеня гідродилатації кінець цистоскопа спрямовують до вічка сечоводу та подають потік рідини під тиском. Для цього іригаційну систему розміщують приблизно на 1 м вище за сечовий міхур і відкривають максимальну подачу рідину [6,7].
Мета дослідження - встановити цистоскопічні прогностичні критерії МСР у дітей.

\section{Матеріали та методи дослідження}

Клінічний матеріал охоплює 270 хворих на МСP IIIV cт., в яких сеча закидалася у 388 сечоводів, та 22 практично здорові дитини. Всі діти віком від 9 місяців до 14 років. Серед них було 152 (56,3\%) пацієнти з одно- та 118 (43,7\%) осіб із двобічним МСР. Враховуючи анатомо-фізіологічні особливості розвитку сечовидільної системи й етапність розвитку дитячого організму, а також особливості перебігу клініки в різні вікові періоди, хворі на МСР за кожним ступенем згруповані за віком: до 1 року, від 1 до 3 років, від 3 до 10 років і від 10 років.

За віком пацієнти розподілилися так: до 1 року 22 (8,15\%) хворі, або 34 сечоводи, з яких з однобічною вадою було 10 (3,7\%), а двобічною - 12 (4,44\%) дітей; від 1 до 3 років - 109 (40,37\%) хворих, або 158 сечоводів, 3 яких з однобічною вадою - 60 (22,22\%), а двобічною - 49 (18,15\%) дітей; від 3 до 10 років - 98 (36,3\%) дітей, або 140 сечоводів, з яких з однобічною вадою 56 (20,74\%), або двобічною - 42 (15,56\%); від 10 років 41 (15,19\%) дитина, або 56 сечоводів, серед яких з однобічною вадою - 26 (9,63\%), а двобічною - 15 (5,56\%) 
Оригінальні дослідження. Урологія та гінекологія

дітей. Хворі на однобічну ваду незначно, лише в 1,3 раза, переважали пацієнтів із двобічним МСР. Практично 50\% хворих становили пацієнти до 3-річного віку, а це 131 (48,52\%) дитина (табл. 1).

Серед обстежених основну частку становили пацієнти з МСР III ст., а це 145 (53,7\%) хворих, або 202 сечоводи. Суттєво менше дітей було 3 вадою II ст. 74 (27,41\%), або 113 сечоводів. І ще менш чисельною виявилася підгрупа MCP IV ст. - 51 (18,89\%) дитина, або 73 сечоводи. Розподіл хворих на МСР за віковими підгрупами залежно від ступеня вади подано в таблиці 2 .

Хворим на МСР поряд зі збором скарг та анамнезу, клінічним оглядом і лабораторними обстеження проводили цистоскопію. Оцінювали стан слизової сечового міхура загалом та в ділянці вічок сечоводів; розташування, форму, ступінь гідродилатації і скоротливу здатність вічок сечоводів. До обстеження залучали хворих на МCP II-IV ст. у період клініко-лабораторної ремісії без клінічних симптомів нейрогенного сечового міхура.

Норму проаналізували у 22 дітей без природжених вад сечовидільної системи переважно з підозрою на доброякісні пухлиноподібні новоутвори в сечовому міхурі за даними ультразвукового дослідження або комп'ютерної томографії - поліпи та з нез'ясованою еритроцитурією, які потребували уточнення. У віковому аспекті вони поділилися так: до 1 року - 3 дитини, від 1 до 3 років - 6, від 3 до 10 років - 8, від 10 років -5 дітей.

Роботу виконували з дотриманням принципів Гельсінської декларації, Конвенції Ради Європи про права людини і біомедицину, ICH GCР та відповідних законів України, що схвалено комісією з питань етики наукових досліджень, експериментальних розробок і наукових творів Львівського національного медичного університету імені Данила Галицького. Від пацієнтів та їхніх батьків отримали інформовану згоду на участь у дослідженні.

Статистичні обрахунки проводили з використанням інтернет-порталу «Медицинская статистика» (http://medstatistic.ru/calculators/calcrisk.html, «Free statistical calculators» MedCalc, MedCalc Software).

Якісні бінарні ознаки, отримані під час цистоскопії, подавали в таблицях сполученості (кростабуляціі). До таблиць кростабуляції вносили абсолютні частоти для всіх можливих поєднань, які взаємовиключали значення ознак, що аналізували. Визначали відносний ризик (RR) і відношення шансів (OR).

Виконували перевірку гіпотези про випадковість розподілу ознаки в певних групах. Тобто оцінювали статистичну значущість відмінностей частот в обстежених групах - перевіряли нульову статистичну гіпо-
Таблиця 3

Шкала продуктивності діагностичних тестів

\begin{tabular}{|l|l|}
\hline Se або Sp & $\begin{array}{l}\text { Здатність позитивних (Se) або від'ємних } \\
\text { (Sp) результатів діагностичного тесту } \\
\text { розпізнавати захворювання }\end{array}$ \\
\hline $0,9-1,0$ & висока \\
\hline $0,7-0,9$ & середня \\
\hline $0,5-0,7$ & низька \\
\hline$<0,5$ & абсурдна \\
\hline
\end{tabular}

тезу про відсутність відмінностей цих величин. Використовували такі критерії для 5\% рівня значущості: Fisher exact p (точний критерій Фішера): one-tailed (односторонній) - $\mathrm{p}_{1}$ i two-tailed (двосторонній тести) - $\mathrm{p}_{2}$.

Для оцінки діагностичної значущості методики використовували спеціальний різновид логістичної регресії - ROC-аналіз (Receiver Operator Characteristic). Він оперує 2 класами подій - з позитивними і негативними результатами. Де частка істинно позитивних випадків визначає «чутливість» (Se), a істинно негативних випадків - «специфічність» (Sp).

$\mathrm{Se}$ - це частка позитивних результатів тесту (чи носіїв маркера) у групі хворих пацієнтів. Чим вища $\mathrm{Se}$ тесту, тим частіше за його допомогою буде виявлятися захворювання. Якщо високочутливий тест дає негативний результат, то він $€$ найінформативнішим, а наявність захворювання - малоімовірною.

$\mathrm{Sp}$ - це частка негативних результатів тесту в групі здорових пацієнтів або частка здорових, які не $\epsilon$ носіями маркера. Чим вища Sp методу, тим надійніше за його допомогою підтверджується захворювання і тим він ефективніший. Високоспецифічні методи - це дискримінатори в діагностиці. Високоспецифічний тест при позитивному його результаті підтверджує захворювання. Тобто тим вища прогностична цінність його позитивного результату. Всі без маркера і всі здорові $\mathrm{Se}=0, \mathrm{Sp}=1$ (табл. 3 ).

\section{Результати дослідження та їх обговорення}

У практично здорових дітей під час цистоскопічного дослідження переважно візуалізували вулканоподібну форму вічок сечоводів (рис. 1).

Тільки у 40\% дітей віком від 10 років виявляли підковоподібні вічка сечоводів (рис. 2).

Такі характеристики вічок сечоводів, як їх розташування в зоні А, ступінь гідродилатації Н0 та активна перистальтика, були притаманні усім практично здоровим дітям незалежно від вікової підгрупи.

Натомість у більшості пацієнтів з МСР переважала підковоподібна форма вічок сечоводів - 127 (47,04\%), яка характеризувалася помірною позитивною асоціацією щодо наявності вади. Так, відносний ризик у 
них становив 1,15 [1,09-1,23]. За формами вади підковоподібні вічка переважали в дітей з однобічним МСР - 69 (25,56\%) до 58 (21,48\%). При двобічному МСР відносний ризик виявився незначно вищим, ніж при однобічному - 1,37 [1,2-1,56] та 1,27 [1,15$1,4]$. В усіх випадках зафіксовано найвищу специфічність - 1,0 та статистично високозначущі відмінності стосовно практично здорових дітей за двостороннім точним критерієм Фішера - $\mathrm{p}_{2}<0,001$. А от чутливість тесту наближалася до межі низького рівня. У хворих на МСР вона становила 0,47 , а саме, при однобічній ваді - 0,45, двобічній - 0,49.

Менша кількість хворих на МСР мали вічка сечоводів у вигляді стадіону - 106 (39,26\%), які також переважали при однобічній формі - 64 (23,7\%) до 42 (15,56\%). Вічка сечоводів у формі стадіону характеризувалися позитивною асоціацією з МСР. Зокрема, у хворих на МСР відносний ризик дорівнював 1,1 $[1,04-1,17]$, а відношення шансів досягало 6,46 [1,4828,22]. Такі ж тенденції простежувалися при однобічному MCP - RR=1,19 [1,08-1,32], OR=7,27 [1,64-32,23] та двобічному - RR=1,21 [1,07-1,36], OR=5,23 [1,2324,81]. У пацієнтів цієї підгрупи зафіксовано високу специфічність - 0,91. А відмінності стосовно норми за двостороннім точним критерієм Фішера були статистично вірогідними. У загальній групі отримали такі показники - $\mathrm{p}_{2}<0,005$; при однобічному МСР $\mathrm{p}_{2}<0,003$ та двобічному - $\mathrm{p}_{2}<0,02$ (рис. 3).

I лише незначна кількість пацієнтів характеризувалася вічками сечоводів у формі ямки для гольфа 37 (13,7\%), які розподілилися між одно- та двобічною формами практично порівно - відповідно 19 (7,04\%) i 18 (6,67\%) (рис. 4). Для вічок сечоводів у формі ямки для гольфа також була притаманна позитивна асоціація з МСР. У загальній групі - RR=1,09 [1,05-1,14], при однобічній ваді - RR=1,17 [1,09-1,24], а двобічній - RR=1,22 [1,12-1,33]. Найвища специфічність відмічалася при усіх формах вади - 1,0. Статистично вірогідні відмінності за одностороннім точним критерієм Фішера виявляли лише у хворих на двобічний MCP - p $_{1}<0,04$ та в загальній групі - p $_{1}<0,05$.

Вічка сечоводів у хворих на МСР переважно були в зоні В - 154 (57,04\%). Це 92 (34,07\%) пацієнти з однобічною вадою та 62 (22,96\%) - $з$ двобічною. Розташування вічок сечоводів у ділянці В характеризувалося помірною позитивною асоціацією з вадою. Зокрема, відносний ризик у загальній групі становив $1,19[1,11-1,28]$, при однобічній ваді - 1,37 [1,2-1,56], двобічній - 1,39 [1,21-1,6]. В усіх випадках специфічність виявилася найвищою - 1,0, а відмінності стосовно норми статистично високозначущими $\mathrm{p}_{1}<0,001$. Чутливість тесту при цьому утримувалася на низькому рівні. Так, у загальній групі $\mathrm{Se}=0,57$, при однобічному МСР - 0,61 і двобічному - 0,53.

Суттєво менше вічок сечоводів виявляли в зоні С - 67 (24,81\%): при однобічному МСР у $34(12,59 \%)$ пацієнтів, при двобічному у 33 (12,22\%). Відносний ризик також незначно переважав одиницю. У загальній групі він дорівнював $1,11[1,06-1,16]$, при однобічній ваді - 1,19 [1,111,27], двобічній - 1,26 [1,14-1,39]. У всіх підгрупах специфічність характеризувалася найвищим рівнем - 1,0 при вірогідних відмінностях стосовно норми. У хворих на МСР - р $_{1}<0,004$, при однобічній ваді - p $_{1}<0,01$, двобічній - p $_{1}<0,003$.

Ще менше вічок сечоводів візуалізували в зоні D 36 (13,33\%), серед яких у 19 (7,04\%) дітей з однобічним МСР та у 17 (6,3\%) осіб з двобічним. Таке розташування також мало позитивну асоціацію з МСР. У загальній групі відносний ризик дорівнював 1,09 $[1,05-1,14]$, у хворих на однобічний МСР - 1,17 [1,09$1,24]$, двобічний - 1,22 [1,12-1,32]. Як і в попередніх випадках, специфічність сягала 1,0. А вірогідні відмінності зафіксували в пацієнтів, за винятком підгрупи з однобічним МСР. Так, у загальній групі $\mathrm{p}_{2}<0,05$, при двобічному МСР - $\mathrm{p}_{1}<0,05$ (рис. 5).

Найменшу кількість вічок сечоводів при МСР виявляли в ділянці А - 13 (4,81\%), серед яких при однобічній ваді - 7 (2,59\%), двобічній - 6 (2,22\%). Розташування вічок сечоводів у зоні А характеризувалося від’ємною асоціацією з наявністю МСР, тобто ризик розвитку захворювання в носіїв цієї ознаки був надто низьким. Зокрема, у загальній групі відносний ризик зменшився до 0,37 [0,24-0,57], у підгрупі однобічної вади - до 0,24 [0,13-0,46], двобічної - до 0,21 [0,110,44]. Відмінності щодо показників у практично здорових дітей були статистично високозначущими за двостороннім точним критерієм Фішера - p $_{2}<0,001$.

Найбільше хворих на МСР мали гідродилатацію вічок сечоводів Н1 ступеня - 173 (64,07\%), які розподілилися на $101(37,41 \%)$ при однобічній ваді та 72 (26,67\%) при двобічній. Н1 ступінь гідродилатації характеризувався позитивною асоціацією з МСР. У загальній групі відносний ризик становив 1,23 $[1,13-1,34]$, при однобічній ваді - 1,43 [1,23-1,66], двобічній - 1,48 [1,25-1,74]. Відмінності стосовно практично здорових дітей виявилися статистично високозначущими за двостороннім точним критерієм Фішера - р2<0,001, а специфічність тесту найвищою - 1,0. При цьому чутливість була низькою. Так, при однобічному МСР вона дорівнювала 0,66, при двобічному - 0,61, у загальній групі - 0,64.

Відчутно менше пацієнтів виявили з вищим Н2 ступенем гідродилатації вічка сечоводу - 


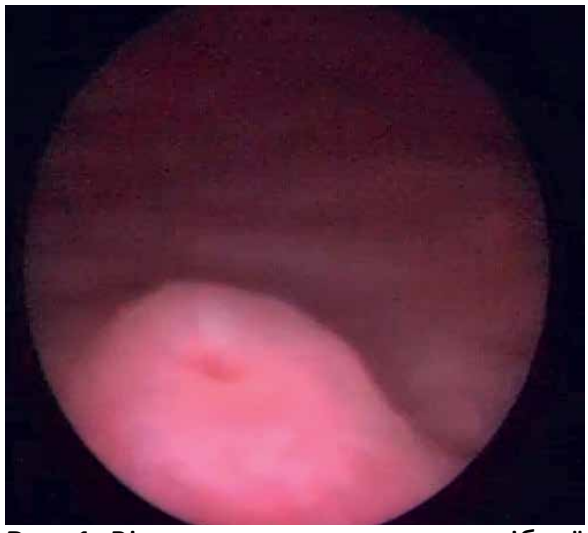

Рис. 1. Вічко сечоводу вулканоподібної форми

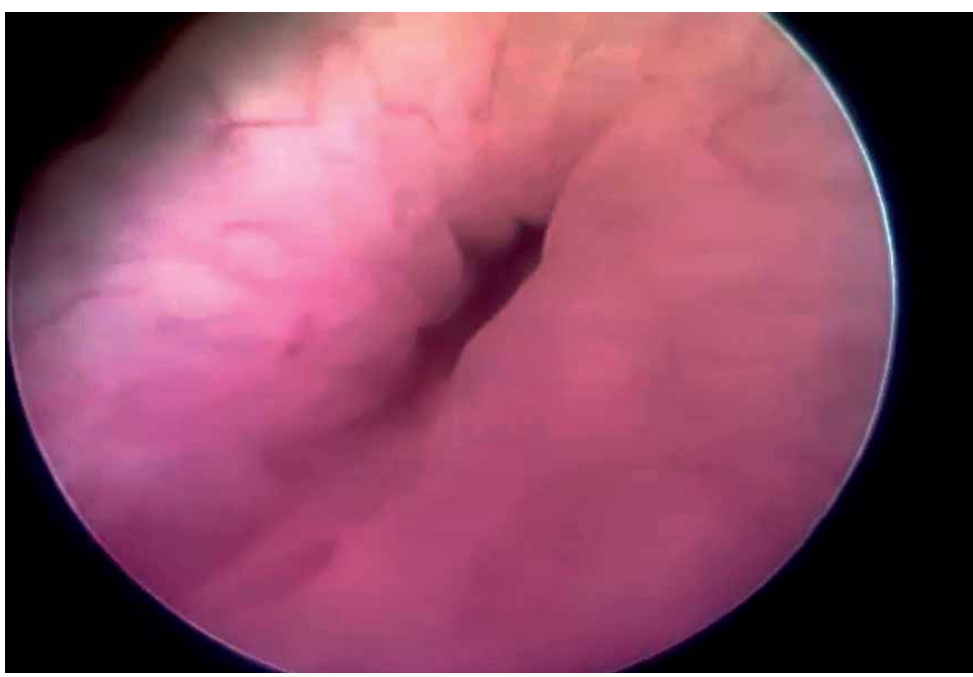

Рис. 4. Вічко сечоводу у формі ямки для гольфа

60 (22,22\%). За формою вади вони розподілилися практично порівну. Так, однобічний МСР діагностували в $31(11,48 \%)$ хворого, двобічний - у 29 (10,74\%). Помірна позитивна асоціація з МСР була притаманна і вічкам сечоводів з $\mathrm{H} 2$ ступенем гідродилатації. 3окрема, у загальній підгрупі відносний ризик дорівнював $1,11[1,06-1,15]$, при однобічному МСР - 1,18 [1,11,27], двобічному - 1,25 [1,14-1,37]. В усіх підгрупах цей тест характеризувався найвищою специфічністю - 1,0 та вірогідними відмінностями щодо норми за двостороннім точним критерієм Фішера. У хворих на МСР отримали $\mathrm{p}_{2}<0,02$, на однобічну ваду $\mathrm{p}_{2}<0,02$, двобічну $-\mathrm{p}_{2}<0,01$.

Ще менше пацієнтів з МСР мали Н3 ступінь гідродилатації вічок сечоводів - 30 (11,11\%), які порівну розподілилися за формами вади - по 15 (5,56\%) дітей. Цей найвищий ступінь гідродилатації вічок сечоводів також характеризувався позитивною асоціацією 3 МСР. Так, відносний ризик у хворих на однобічний МСР становив 1,16 [1,09-1,24], двобічний - 1,21 $[1,12-1,32]$, загалом - 1,09 [1,05-1,13]. При цьому специфічність в усіх пацієнтів була найвищою - 1,0.

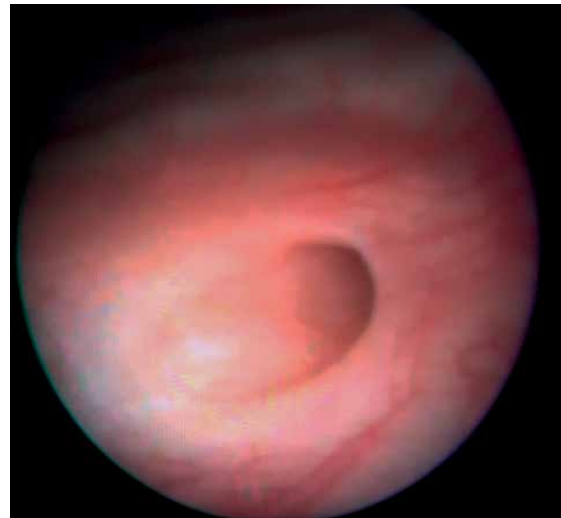

Рис. 3. Вічко сечоводу у формі стадіону

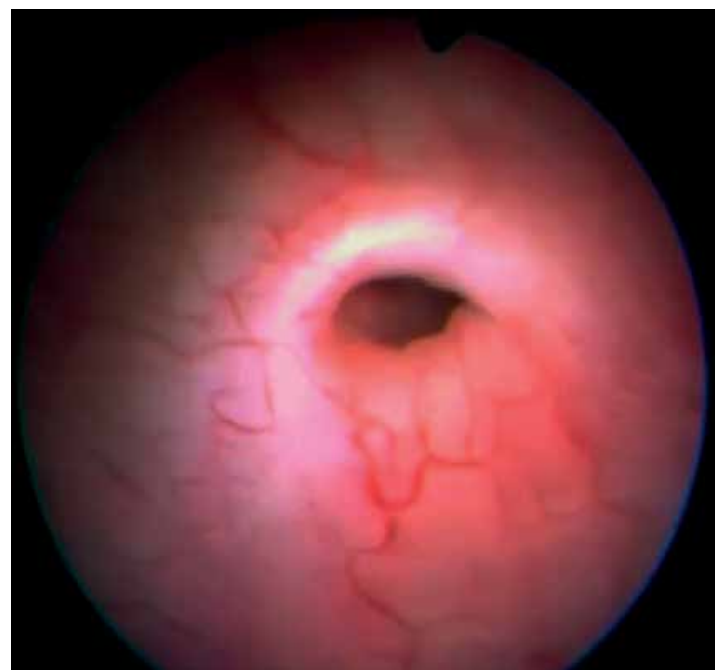

Рис. 5. Вічко сечоводу у формі ямки для гольфа з латералізацією в зону D

Найменше хворих на МСР виявили з Н0 ступенем гідродилатації вічок сечоводів - 7 (2,59\%), з яких у $5(1,85 \%)$ діагностували однобічну ваду, у 2 (0,74\%) - двобічну. Лише цей ступінь гідродилатації вічок сечоводів характеризувався від’ємною асоціацією з МСР. Зокрема, відносний ризик при однобічному МСР дорівнював тільки 0,19 [0,08-0,41], при двобічному - 0,08 [0,02-0,31], у загальній групі $0,24[0,13-0,46]$. До показників у практично здорових дітей в усіх хворих фіксували статистично високозначущі відмінності за двостороннім точним критерієм Фішера - $\mathrm{p}_{2}<0,001$.

У хворих на МСР однозначно переважала в'яла перистальтика вічок сечоводів - 252 (93,33\%), з яких при однобічній патології - 141 (52,22\%), а двобічній 111 (41,11\%). Це дало виражену позитивну асоціацію з МСР. Найбільший відносний ризик фіксували при двобічному МСР - 4,14 [2,17-7,9], дещо нижчий при однобічному - 3,0 [1,85-4,86], загалом - 2,22 [1,58$3,13]$. Відмінності стосовно норми були статистично високозначущими в усіх підгрупах за двостороннім точним критерієм Фішера - $\mathrm{p}_{2}<0,001$. Цей тест харак- 
теризувався найвищою специфічністю - 1,0 та високою чутливістю. Так, у хворих на двобічний МСР $\mathrm{Se}=0,94$, а в інших підгрупах $\mathrm{Se}=0,93$.

Активну перистальтику вічок сечоводів при МСР виявили лише у 18 (6,67\%) пацієнтів, а це 11 (4,07\%) дітей з однобічною та 7 (2,59\%) з двобічною вадою. Активна перистальтика характеризувалася від’ємною асоціацією з МСР. Так, відносний ризик при однобічній ваді становив $0,33[0,21-0,54]$, двобічній - 0,24 [0,13-0,46], загалом - 0,45 [0,32-0,63]. Відмінності до норми за двостороннім точним критерієм Фішера були статистично високозначущими - $\mathrm{p}_{2}<0,001$.

Отже, у хворих на МСР вічка сечоводів, які мають конфігурацію з більш вираженими ознаками глибочіння, розміщуються значно латеральніше від середини сечового міхура. У пацієнтів з МСР у цілому віддзеркалюються відмінності, притаманні для хворих на одно- і двобічну форми вади $[9,10]$.

\section{Висновки}

Для вічок сечоводів у формі стадіону і з більш вираженими ознаками глибочіння, які зміщені в зону В і латеральніше на бокову стінку сечового міхура, зі ступенем гідродилатації понад Н1, притаманна позитивна асоціація щодо МСР при найвищій специфічності тестів.

Несприятливими прогностичними діагностичними маркерами для ефективних мініінвазивних втручань у хворих на МСР слід вважати вічка сечоводів, у яких поєднуються такі морфотопографічні характеристики, як виражені ознаки глибочіння до форми ямки для гольфа, латералізація на бокову стінку сечового міхура в зону D і гідродилатація Н3 ступеня.

Автори заявляють про відсутність конфлікту iнтересів.

\section{References/Лiтература}

1. Aksenova ME, Turpitko OY, Gusarova TN, Nazarova NF, Ignatova MS. (2001). The role of urinary tract infection in the formation of reflux nephropathy in children. Nephrology and dialysis. 2: 296-297. [Аксенова МЕ, Турпитко ОЮ, Гусарова ТН, Назарова НФ, Игнатова МС. (2001). Роль инфекции мочевой системы в формировании рефлюкс-нефропатии у детей. Нефрология и диализ. 2: 296-297].

2. Basic J, Golubovic E, Miljkovic P et al. (2008). Microalbuminuria in children with vesicoureteral reflux. Renal failure. 30 (6): 639-643.

3. Glassberg KI, Hackett RE, Waterhouse K. (1981). Congenital anomalies of the kidney, ureter, and bladder. Urology. By Harry
S. Goldsmith, Lester Karafin, and A. Richard Kendall. Vol. 1. Philadelphia: Harper \& Row.

4. Jacyk SP, Burkin AG, Sharkov SM et al. (2014). Comparative evaluation of methods of surgical correction of vesicoureteral reflux in children. Questions of modern pediatrics. 13 (2): 129131. [Яцык СП, Буркин АГ, Шарков СМ и др. (2014). Сравнительная оценка методов хирургической коррекции пузырно-мочеточникового рефлюкса у детей. Вопросы современной педиатрии. 13 (2): 129-131].

5. Khoury AE, Bägli DJ. (2016). Vesicoureteral Reflux. CampbellWalsh urology eleventh edition review. By MacDougal, William Scott, and Meredith F. Campbell. Philadelphia: Elsevier.

6. Kirsch AJ, Kaye JD, Cerwinka WH et al. (2009). Dynamic hydrodistention of the ureteral orifice: a novel grading system with high interobserver concordance and correlation with vesicoureteral reflux grade. The Journal of urology. 182 (4S): 1688-1693.

7. Läckgren G, Kirsch AJ. (2010). Endoscopic treatment of vesicoureteral reflux. BJU international. 105 (9): 1332-1347.

8. Lyon RP, Marshall S, Tanagho EA. (1969). The ureteral orifice: its configuration and competency. The Journal of urology. 102 (4): 504-509.

9. Nakonechnyy RA, Nakonechnyi AY. (2013). Vesicoureteral reflux in children: endovesical correction methods. Pediatric Surgery. 2: 19-24. [Наконечний РА, Наконечний АЙ. (2013). Ендовезикальні способи корекції міхуровосечовідного рефлюксу в дітей. Хірургія дитячого віку. 2: 19-24].

10. Nakonechnyy RA. (2015). The efficiency of mini-invasive treatment of vesicoureteral reflux in children. Urology. 2: 74-78. [Наконечний РА. (2015). Ефективність мініінвазивного лікування міхуровосечовідного рефлюксу у дітей. Урологія. 2: 74-78].

11. Park John M. (2006). Vesicoureteral Reflux: anatomic and functional basis of etiology. The Kelalis-King-Belman Textbook of Clinical Pediatric Urology. Ed. Steven G Docimo, Douglas A Canning, Antoine E Khoury. Fifth ed. CRC Press.

12. Romanenko GO, Kundin VYU. (2010). Renoscintigraphy investigation of cystoureteral reflux in children with various kidney and urinary tract pathologies. Ukrainian Radiological Journal. 13 (3): 320-323. [Романенко ГО, Кундін ВЮ. (2010). Реносцинтиграфічні дослідження міхурово-сечовідних рефлюксів у дітей із різною патологією нирок та сечовивідних шляхів. Український радіологічний журнал. 13 (3): 320-323].

13. Ryabtseva AV, Jacyk JV, Fomin DK. (2010). New approaches to the diagnosis of vesicoureteral reflux in children. Pediatric Pharmacology. 7 (3): 95-97. [Рябцева АВ, Яцык СП, Фомин ДК. (2010). Новые подходы к диагностике пузырно-мочеточникового рефлюкса у детей. Педиатрическая фармакология. 7 (3): 95-97].

14. Sargent MA. (2000). Opinion: what is the normal prevalence of vesicoureteral reflux? Pediatric radiology. 30: 9.

15. Tanagho EA, Nguyen HT. (2013). Vesicoureteral Reflux. Smith \& Tanagho's General Urology. By Smith Donald Ridgeway, Tom F Lue, Jack W McAninch. Eighteenth ed. McGraw Hill Medical.

16. Zorkin SN, Gusarova TN, Borisova SA, Barsegyan ER. (2011). Endoscopic correction of vesicoureteral reflux in children. Pediatric Surgery. 2: 23-27. [Зоркин СН, Гусарова ТН, Борисова СА, Барсегян ЕР. (2011). Эндоскопическая коррекция пузырно-мочеточникового рефлюкса у детей. Детская хирургия. 2: 23-27].

\section{Відомості про авторів:}

Наконечний Ростислав Андрійович - к.мед.н, асистент каф. дитячої хірургії Львівського НМУ імені Д. Галицького. Адреса: м. Львів, вул. П. Орлика, 4; тел. (032) 291-70-50. https://orcid.org/0000-0003-0645-3361.

Наконечний Андрій Йосифович - д.мед.н., проф. каф. дитячої хірургії, проректор з наукової роботи Львівського НмУ імені Д. Галицького. Адреса: м. Львів, вул. Пекарська, 69; тел. (032) 275-59-47. https://orcid.org/0000-0003-1402-6642.

Стаття надійшла до редакції 14.07.2021 р., прийнята до друку 8.09.2021 p. 


\title{
О.Д. Фофанов ${ }^{1}$ А.П. Юрцева ${ }^{1}$, Б.М. Зіняк², Ю.Р. Доценко², В.О. Фофанов \\ Власний досвід реконструктивно-пластичних операцій на сечовому міхурі в дітей
}

\author{
${ }^{1}$ Івано-Франківський національний медичний університет, Украйна \\ ${ }^{2}$ КНП «Івано-Франківська обласна дитяча клінічна лікарня Івано-Франківської обласної ради», \\ Україна
}

Paediatric surgery.Ukraine.2021.3(72):43-50; doi 10.15574/PS.2021.72.43

For citation: Fofanov OD, Jurtseva AP, Zinyak BM, Dotsenko YuR, Fofanov VO. (2021). The own experience of reconstructive-plastic operations on the bladder in children. Paediatric Surgery.Ukraine. 3(72):43-50; doi 10.15574/PS.2021.72.43.

В Україні складна хірургічна реконструкція дистальних сечових шляхів при тяжкій дисфункції сечового міхура в дітей виконується недостатньо часто, враховуючи кількість дітей, які потребують такої операції. Ці оперативні втручання здійснювалися в Україні запрошеними із закордону фахівцями. Тому наводимо перший власний досвід складної хірургічної реконструкції дистальних сечових шляхів у дітей.

Мета - поліпшити якість життя дітей з тяжкою дисфункцією сечового міхура.

Матеріали та методи. Проаналізовано результати реконструктивно-пластичних операцій на сечовому міхурі в 7 дітей з тяжкою дисфункцією сечового міхура. У 4 хворих був нейрогенний сечовий міхур (у 3 з них - спінальний сечовий міхур), у 2 хворих - мікроцист після хірургічної корекції екстрофії сечового міхура та тотальної епіспадії. Аугментаційну ілеоцистопластику виконано у 3 дітей, у 2 з них проведено також апендикоцистостомію, у 3 хворих - тільки апендикоцистостомію. Оцінено стан сечових шляхів, ступінь утримання сечі, післяопераційні ускладнення та якість життя оперованих дітей.

Результати. Усі оперовані діти одужали. Сечові міхурі у 3 хворих після аугментації мають достатній об’єм і повністю забезпечують резервуарну функцію. В оперованих дітей не виявлено метаболічного ацидозу або інших серйозних метаболічних порушень, які описують інші автори. Також не відмічено уролітіазу після операції. У 5 хворих, яким накладено апендикоцистостому, остання катетеризується добре, має добрий косметичний ефект. У 4 з 5 хворих немає підтікання сечі через стому. У всіх прооперованих дітей вилікувано міхурово-сечовідний рефлюкс та хронічний пієлонефрит. За результатами анкетування встановлено поліпшення більшості параметрів якості життя оперованих хворих (припинення інфекції сечових шляхів, повне утримання сечі з більш рідкісним і контрольованим сечовипусканням, можливість відвідування дитячих колективів та соціальна адаптація цих дітей у суспільстві).

Висновки. Виходячи з першого власного досвіду проведення аугментаційної ілеоцистопластики та апендикоцистостомії за Mitrofanoff, відмічено добрий ефект цих реконструктивно-пластичних операцій. У всіх оперованих хворих істотно поліпшилася якість життя - досягнуто контрольованого сечопуску, припинено прогресування ушкодження нирок. Усі післяопераційні ускладнення успішно корегуються. Велике значення для досягнення доброго ефекту лікування має правильний вибір обсягу хірургічної реконструкції сечових шляхів у кожному конкретному випадку.

Дослідження виконано відповідно до принципів Гельсінської декларації. Протокол дослідження ухвалено Локальним етичним комітетом всіх зазначених у роботі установ. На проведення досліджень отримано інформовану згоду батьків дітей.

Автори заявляють про відсутність конфлікту інтересів.

Ключові слова: аугментаційна ілеоцистопластика, апендикоцистостомія, діти. 


\section{The own experience of reconstructive-plastic operations on the bladder in children O.D. Fofanov ${ }^{1}$, A.P. Jurtseva ${ }^{1}$, B.M. Zinyak ${ }^{2}$, Yu.R. Dotsenko ${ }^{2}$, V.O. Fofanov ${ }^{1}$}

${ }^{1}$ Ivano-Frankivsk National Medical University, Ukraine

2Ivano-Frankivsk Regional Children's Clinical Hospital of Ivano-Frankivsk Regional Council, Ukraine

In our country, complex surgical reconstruction of the distal urinary tract in severe bladder dysfunction in children is performed infrequently, given the number of children who need these operations. These operations were carried out in our country by specialists invited from abroad. Therefore, we want to share our first experience of performing a complex surgical reconstruction of the distal urinary tract in children.

Purpose - to improve the quality of life of children with severe bladder dysfunction.

Materials and methods. The results of reconstructive and plastic operations on the bladder in 7 children with severe bladder dysfunction were analyzed. Four patients had a neurogenic bladder 3 of them had a spinal bladder), and two patients had a microcyst after surgical correction of bladder exstrophy and total epispadias. Augmentation ileocystoplasty was performed in 3 children, two of them also underwent appendicocystostomy, 3 patients underwent only appendicocystostomy. An assessment of the urinary tract condition, the degree of urinary retention, postoperative complications and quality of life of operated children.

Results. All operated children recovered. The bladders in three patients after augmentation have sufficient volume and fully provide reservoir function. We did not observe metabolic acidosis or other serious metabolic disorders described by other authors in the children we operated on. Urolithiasis was also not observed after surgery. In 5 patients who underwent appendicocystostomy, the latter is well catheterized, has a good cosmetic effect. In 4 out of 5 patients there is no leakage of urine through the stoma. All operated children were recovered for vesicoureteral reflux and chronic pyelonephritis. According to the results of the survey, the improvement of most parameters of quality of life of operated patients (cessation of urinary tract infection, complete urinary retention with more infrequent and controlled urination, the ability to visit children's groups and social adaptation of these children in society).

Conclusions. Based on the first own experience of augmentation ileocystoplasty and appendicocystostomy according to Mitrofanoff, the good efficiency of these reconstructive-plastic operations is noted. In all operated patients the quality of life significantly improved - controlled urination was achieved, the progression of kidney damage was stopped. All postoperative complications are successfully corrected. Of great importance for achieving a good effect of treatment is the correct choice of the the urinary tract surgical reconstruction type in each case.

The research was carried out in accordance with the principles of the Helsinki declaration. The study protocol was approved by the Local ethics committee of all participating institution. The informed consent of the patient was obtained for conducting the studies.

No conflict of interest was declared by the authors.

Key words: augmentation ileocystoplasty, appendicocystostomy, children.

\section{Собственный опыт реконструктивно-пластических операций на мочевом пузыре у детей \\ А.Д. Фофанов ${ }^{1}$, А.П. Юрцева ${ }^{1}$, Б.М. Зиняк ${ }^{2}$ Ю.Р. Доченко ${ }^{2}$ В.А. Фофанов ${ }^{1}$}

${ }_{1}^{1}$ Ивано-Франковский национальный медицинский университет, Украина

${ }^{2}$ КНП «Ивано-Франковская областная детская клиническая больница Ивано-Франковского областного совета», Украина

В Украине сложная хирургическая реконструкция дистальных мочевых путей при тяжелой дисфункции мочевого пузыря у детей выполняется недостаточно часто, учитывая количество детей, которым необходима такая операция. Эти оперативные вмешательства осуществлялись в нашей стране приглашенными из-за рубежа специалистами. Поэтому представляем первый собственный опыт осуществления сложной хирургической реконструкции дистальных мочевых путей у детей.

Цель - улучшить качество жизни детей с тяжелой дисфункцией мочевого пузыря.

Материалы и методы. Проанализированы результаты реконструктивно-пластических операций на мочевом пузыре у 7 детей с тяжелой дисфункцией мочевого пузыря. У 4 больных был нейрогенный мочевой пузырь (у 3 из них - спинальный мочевой пузырь), у 2 больных-микроцист после хирургической коррекции экстрофии мочевого пузыря и тотальной эписпадии. Аугментационная илеоцистопластика выполнена у 3 детей, у 2 из них проведена также аппендикоцистостомия, у 3 больных - только аппендикоцистостомия. Оценены состояние мочевых путей, степень удержания мочи, послеоперационные осложнения и качество жизни оперированных детей.

Результаты. Все оперированные дети выздоровели. Мочевой пузырь у 3 больных после аугментации имеет достаточный объем и полностью обеспечивает резервуарную функцию. У оперированных нами детей не выявлен метаболический ацидоз или другие серьезные метаболические нарушения, которые описывают другие авторы. Также не выявлен уролитиаз после операции. У 5 больных, которым наложена аппендикоцистостома, последняя катетеризуется хорошо, имеет хороший косметический эффект. У 4 из 5 больных нет подтекания мочи из стомы. У всех прооперированных детей не выявлены пузырно-мочеточниковый рефлюкс и хронический пиелонефрит. По результатам анкетирования установлено улучшение большинства параметров качества жизни оперированных больных (прекращение инфекции мочевых путей, полное удержание мочи с более редким и контролируемым мочеиспусканием, возможность посещения детских коллективов и социальная адаптация этих детей в обществе).

Выводы. Исходя из первого собственного опыта проведения аугментационной илеоцистопластики и аппендикоцистостомии по Міtrofanoff, отмечен положительный эффект этих реконструктивно-пластических операций. У всех оперированных больных существенно улучшилось качество жизни достигнуто контролируемое мочеиспускание, прекращено прогрессирование повреждения почек. Все послеоперационные осложнения успешно корректируются. Большое значение для достижения хорошего эффекта лечения имеет правильный выбор объема хирургической реконструкции мочевых путей в каждом конкретном случае.

Исследование выполнено в соответствии с принципами Хельсинкской декларации. Протокол исследования одобрен Локальным этическим комитетом всех участвующих учреждений. На проведение исследований получено информированное согласие родителей детей.

Авторы заявляют об отсутствии конфликта интересов.

Ключевые слова: аугментационная илеоцистопластика, аппендикоцистостомия, дети.

\section{Вступ}

Серйозні порушення функції дистальних відділів сечового тракту в дітей призводять до хронічної інфекції сечових шляхів, сечової інконтиненції, хронічної ниркової недостатності (ХНH). Найпоширенішими причинами дисфункції дистальних сечових шляхів (ДСШ) є нейрогенна дисфункція сечового міхура, особливо та, що зумовлена спінальним дизрафізмом (спінальний сечовий міхур), а також вроджені вади розвитку ДСШ (екстрофія сечового міхура, епіспадія, екстрофія клоаки) $[1,9,14]$. Дефекти нервової трубки, що призводять до тяжкої дисфункції сечового міхура, зустрічаються з частотою до 52:100 000 новонароджених. Основними клінічними 
проявами нейрогенної дисфункції сечового міхура $€$ рецидивна інфекція сечових шляхів, нетримання сечі. При гіпертонусі сечового міхура підвищується внутрішньоміхуровий тиск, порушується скоротлива здатність міхура, утворюються множинні дивертикули, стінки втрачають еластичність і склерозуються. Нерідко це призводить до міхурово-сечовідного рефлюксу (МСР), ХНH [2,5,12-14].

Екстрофія сечового міхура та екстрофія клоаки належать до рідкісних урогенітальних мальформацій, зустрічаються з сумарною частотою до 3,5:100000 живих новонароджених. Після хірургічної корекції цих вад у більшості випадків сечовий міхур має дуже малий об'єм (мікроцист), стінки міхура склерозовані, скоротлива здатність різко порушена, а резервуарна функція міхура практично відсутня. При цьому клінічно спостерігаються нетримання сечі (часто - парадоксальна ішурія), рецидивні інфекції сечових шляхів. Без адекватного лікування розвивається ХНН $[3,4,7]$.

Сучасне лікування дисфункції ДСШ у дітей передбачає чисту періодичну самокатетеризацію (ЧПК) сечового міхура, запропоновану J. Lapides [8], медикаментозне лікування (антихолінергічні препарати, ботулінотоксин А тощо) та хірургічну реконструкцію ДСШ $[1,5,7,9,14]$. Хірургічна реконструкція включає збільшення сечового міхура (аугментаційна цистопластика - АЦП) i/або створення континентної катетеризаційної цистостоми. Показами до збільшення об'єму сечового міхура (аугментації) є мікроцист, високий внутрішньоміхуровий тиск, нетримання сечі, рецидивна інфекція сечових шляхів, ХНН, неефективність консервативного лікування. АЦП дає змогу створити достатній за об'ємом резервуар для сечі, що забезпечує значно менш часту катетеризацію міхура; забезпечити еластичність і податливість створеного резервуару; обмежити скорочувальну здатність міхура; знизити внутрішньоміхуровий тиск; попередити прогресування МСР, інфекції сечових шляхів і ХНН $[4,6,7]$.

Аугментаційна цистопластика являє собою пластичну операцію, що полягає у збільшенні сечового міхура завдяки імплантації детубуляризованого клаптя з травного каналу зі збереженою судинною ніжкою. Для аугментації використовують шлунок, тонку або товсту кишку. Найчастіше застосовують здухвинну кишку, дещо рідше - сигмоподібну кишку. Найбільша популярність здухвинної кишки для аугментації пояснюється ії меншою скоротливою здатністю [4,6,7].

Часто АЦП доповнюється апендикоцистостомією (операція Mitrofanoff) [10]. Головна мета цієї операції це забезпечення утримання сечі, контрольованого сечопуску шляхом самокатетеризації сечового міхура через апендикостому. Принцип Mitrofanoff $€$ доброю альтернативою ЧПК через уретру, оскільки $є$ зручнішим для пацієнтів та їхніх батьків та забезпечує кращу континенцію. Операцію Mitrofanoff виконують не тільки разом з АЦП, але і як окреме хірургічне втручання, що проводять при стійкому нетриманні сечі, резистентному до інших методів лікування. Тому ця операція значно поширена в багатьох країнах $[3,7,10]$. У разі відсутності червоподібного відростка або неможливості його використання для континентної цистосто-

\section{Таблиця 1}

Розподіл хворих за характером патології

\begin{tabular}{|c|c|c|}
\hline \multicolumn{2}{|l|}{ Характер патології } & \multirow{2}{*}{$\begin{array}{l}\text { Кількість хворих (n=7) } \\
2\end{array}$} \\
\hline Основний діагноз & Екстрофія сечового міхура / епіспадія, мікроцист & \\
\hline & Епіспадія, тотальна форма, мікроцист & 1 \\
\hline & Нейрогенний сечовий міхур & 1 \\
\hline & Спінальний сечовий міхур & 3 \\
\hline \multirow[t]{5}{*}{ Ускладнення } & Рефлюксуючий мегауретер & 5 \\
\hline & Хронічний рецидивний пієлонефрит & 5 \\
\hline & Повне нетримання сечі & 4 \\
\hline & Часткове нетримання сечі & 2 \\
\hline & Хронічна ниркова недостатність & 2 \\
\hline \multirow[t]{7}{*}{ Супутні захворювання } & Подвоєння нирок & 2 \\
\hline & Білково-енергетична недостатність & 1 \\
\hline & Анемія & 2 \\
\hline & Гідроцефалія & 2 \\
\hline & Дифузний зоб & 1 \\
\hline & Сколіоз & 2 \\
\hline & Аплазія крижової кістки & 1 \\
\hline
\end{tabular}


ми, застосовують ретубуляризований сегмент тонкої кишки на судинній ніжці (стома Monti) [11].

В Україні складна хірургічна реконструкція ДСШ при тяжкій дисфункції сечового міхура в дітей виконується недостатньо часто, враховуючи кількість дітей, які потребують такої операції. Це оперативне втручання проводили в Україні запрошені із закордону фахівці. Тому наводимо перший власний досвід складної хірургічної реконструкції ДСШ.

Мета дослідження - поліпшити якість життя дітей з тяжкою дисфункцією сечового міхура шляхом впровадження хірургічної реконструкції ДСШ.

\section{Матеріали та методи дослідження}

Протягом останніх чотирьох років у клініці дитячої хірургії Івано-Франківського національного медичного університету прооперовано 7 дітей, яким проведено АЦП і/або апендиковезикостомію з приводу тяжкої дисфункції сечового міхура, уперше без залучення закордонних фахівців. Серед оперованих хворих було 4 дівчинки і 3 хлопчика. Вік дітей становив від 3 років 8 місяців до 19 років, медіана - 11 років 5 місяців.

У 4 дітей основним захворюванням був нейрогенний сечовий міхур, у 3 з них - спінальний сечовий міхур (діти раніше прооперовані з приводу спинномозкової грижі). 2 дитини оперовані з приводу екстрофії сечового міхура / епіспадії, а 1 - 3 приводу тотальної форми епіспадіiі. У цих 3 хворих був мікроцист. У 5 хворих діагностували рефлюксуючий мегауретер (у 3 з них - двобічний), у 5 - хронічний рецидивний пієлонефрит. У 4 дітей було повне нетримання сечі, у 2 часткове. У 2 дітей виникла ХНН (табл. 1).

При урологічному обстеженні у 2 хворих діагностували подвоєння нирки і сечоводу. Тяжку супутню патологію виявили у 4 дітей (білково-енергетична недостатність, анемія, дифузний зоб, аплазія крижової кістки, гідроцефалія, сколіоз).

До госпіталізації в клініку на хірургічне втручання усі діти неодноразово проходили обстеження,

Таблиця 2

Розподіл хворих за видом хірургічної реконструкції

\begin{tabular}{|l|l|}
\hline Вид хірургічної реконструкції & $\begin{array}{l}\text { Кількість хворих } \\
\text { (n=7) }\end{array}$ \\
\hline $\begin{array}{l}\text { Аугментаційна ілеоцистопластика } \\
\text { + апендикоцистостомія }\end{array}$ & 3 \\
\hline Аугментаційна ілеоцистопластика & 1 \\
\hline Апендикоцистостомія & 3 \\
\hline Антирефлюксна операція & 2 \\
\hline Ушивання шийки сечового міхура & 3 \\
\hline $\begin{array}{l}\text { Уретероуретеростомія кінець у бік } \\
+ \text { реімплантація сечоводу в сечо- } \\
\text { вий міхур }\end{array}$ & 1 \\
\hline
\end{tabular}

консервативне і хірургічне лікування в різних клініках України та за кордоном. На момент госпіталізації дітей ретельно вивчали анамнез, попередню медичну документацію, об'єктивне обстеження. До операції проводили традиційне лабораторне та урологічне обстеження, яке включало ультрасонографію, екскреторну урографію, мікційну цистографію, комп'ютерну томографію, сцинтиграфію нирок, цистоскопію.

Ефект хірургічного лікування оцінювали за клінічними та лабораторними даними, а також за даними урологічного та ендоскопічного обстеження (перебіг післяопераційного періоду, клінічні та лабораторні ознаки інфекції сечових шляхів, наявність ранніх і віддалених післяопераційних ускладнень, характер утримання сечі, стан нирок, сечоводів та сечового міхура, якість життя оперованих дітей). Оцінку якості життя проводили за допомогою анкетування дітей та батьків.

Усі хворі після операції перебувають під спостереженням. Віддалені результати лікування вивчаються в термін від 6 місяців до 4 років.

Оскільки характер основної патології та порушень функції ДСШ у хворих різняться, стратегію хірургічного лікування обирали індивідуально в кожному конкретному випадку (табл. 2). План операції детально обговорили і узгодили з батьками хворих.

Для формування достатнього об’єму резервуара провели реконфігурацію клаптя тонкої кишки, склавши детубуляризовану кишку у двох взаємно перпендикулярних напрямках. Така реконфігурація з утворенням сферичної форми клаптя також, згідно із законом Лапласа, забезпечує зниження внутрішньоміхурового тиску в 4 рази (рис. 1). Безперервність тонкої кишки відновили накладанням анастомозу кінець до кінця. Усі анастомози виконали однорядним безперервним евертованим швом (PDS та Vicryl 4-0 чи 3-0). Дренували сечовий міхур (епіцистостома) та перивезикальний простір. У 3 дітей АЦП доповнили апендикоцистостомією за Mitrofanoff. В 1 хворого з мікроцистом виконали тільки АЦП, оскільки функція утримання сечі в нього зберігалася. У 2 дітей під час АЦП провели також антирефлюксні операції - відкриту підслизову імплантацію об’ємоутворюючого гелю у вічка сечоводів.

Аугментаційну ілеоцистопластику провели 4 дітям, у всіх для аугментації використали сегмент здухвинної кишки довжиною від 45 см до 55 см на судинній ніжці. Кишку для імплантації взяли на відстані 15-20 см від ілеоцекального кута, виконали їі детубуляризацію і сформували сферичної форми 
клапоть, який вшили в попередньо розкритий сечовий міхур, сформувавши резервуар достатнього об’єму (рис. 2).

Апендикоцистостомію провели 6 хворим, серед них 3 дітям - без аугментації сечового міхура. 4 хворим виконали мобілізацію правої половини товстої кишки. Основу відростка разом з частиною сліпої кишки відсікли, ушили рану сліпої кишки. Верхівку відростка відсікли і наклали апендикоцистоанастомоз на задньобоковій стінці сечового міхура праворуч з проведенням відростка у підслизовому тунелі міхура (довжиною не менше 2-2,5 см), створивши антирефлюксний клапан. Основу відростка вивели на передню черевну стінку з ушиванням у нього V-подібного клаптя шкіри для профілактики стенозу стоми. 1 хворому, у зв'язку з дуже малими розмірами сечового міхура, апендикс імплантували в кишкову частину неоцисту після аугментації (рис. 3). У всіх випадках апендикостому вивели в пупок, що мало добрий косметичний ефект і було зручним для катетеризації.

Одній 13-річній хворій, у зв'язку з анатомічними особливостями (апендикс довжиною до 5 см, деформований, у зрощеннях, розташований ретроцекально, сліпа кишка високо розміщена), провели апендикоцековезикоумбілікостомію у власній модифікації. Після ретельної мобілізації правої половини товстої кишки і адгезіолізису апендикс мобілізували зі збереженням судинної ніжки, викроїли клапоть сліпої кишки розмірами $3 \times 2$ см. Провели тубуляризацію клаптя, а потім зшили його з відростком, і таким чином апендикс подовжили на 2 см. Це дало змогу накласти апендикоцекостому з антирефлюксним захистом і вивести їі на пупок.

У 3 хворих апендикоцистостомію доповнили ушиванням шийки сечового міхура, ще у 2 дітей закрили шийку міхура шляхом ендоскопічної підслизової імплантації об'ємоутворюючого гелю.

Дослідження виконано відповідно до принципів Гельсінської декларації. Протокол дослідження ухвалений Локальним етичним комітетом ІваноФранківського національного медичного університету. На проведення досліджень отримано інформовану згоду батьків дітей.

\section{Результати дослідження та їх обговорення}

Усі прооперовані діти одужали. Післяопераційний перебіг у 6 хворих був задовільний. В 1 хлопчика виникло ускладнення в ранньому післяопераційному періоді після АЦП - некроз сегменту здухвинної кишки. Хворому провели релапаротомію на 8-му добу після АЦП. Виявили некроз до 25 см здухвинної
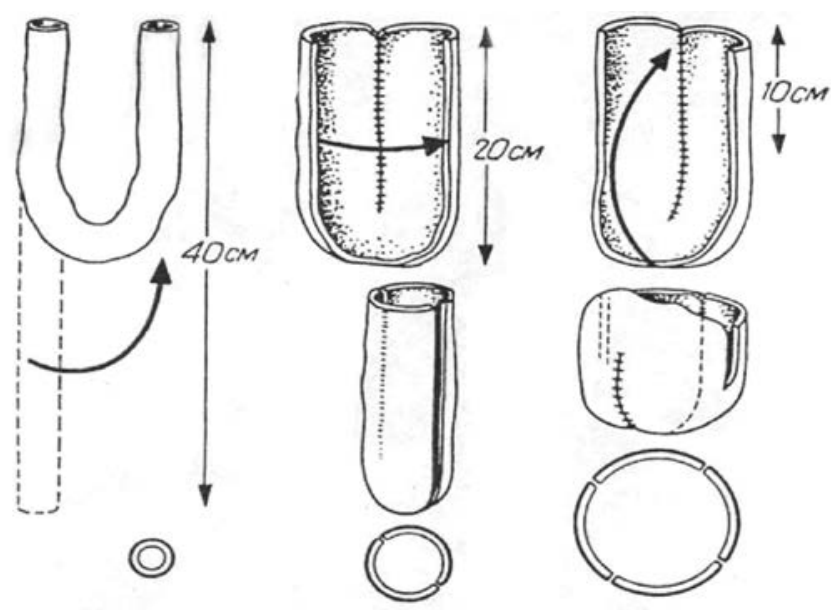

Рис. 1. Схема реконфігурації тонкої кишки під час аугментаційної цистопластики (В.І. Аверін)

кишки проксимальніше анастомозу внаслідок тромбозу брижових судин. Анастомоз був достатній. Трансплантат - удоброму стані, життєздатний. Провели резекцію некротизованого сегменту здухвинної кишки, ілеоасцендостомію. У подальшому післяопераційний перебіг - без ускладнень.

У 3 дітей після АЦП виявили накопичення слизу в сечовому міхурі, що потребує періодичного 1 раз на місяць) промивання сечового міхура. Сечові міхурі у цих хворих після аугментації стали достатнього об’єму (200-250 мл), за даними ультразвукового дослыдження та цистографії, і повністю забезпечують резервуарну функцію (рис. 4).

У всіх випадках вилікували МСР та хронічний пієлонефрит. В оперованих дітей не спостерігали метаболічного ацидозу чи інших серйозних метаболічних порушень, які описують інші автори $[4,6,7]$. Також не спостерігали уролітіазу після операції. У 2 хворих, яким провели ушивання шийки сечового міхура, виникло незначне підтікання сечі через уретру при переповненні міхура. Це ускладнення ліквідували шляхом ендоскопічної підслизової імплантації гелю в шийку сечового міхура.

У всіх 6 хворих, яким наклали апендикоцистостому, остання катетеризується добре, має добрий косметичний ефект, практично непомітна в пупку (рис. 5).

Катетеризацію здійснюють батьки та самі хворі. У 5 з 6 хворих створений клапанний механізм повністю забезпечує утримання сечі. В 1 хворої спостерігається підтікання сечі через апендикоцистостому. У цієї 3-річної дівчинки був спінальний сечовий міхур з нетриманням сечі, двобічний рефлюксуючий мегауретер, вторинний хронічний пієлонефрит, подвоєння правої нирки і сечоводу. Дитині була раніше накладена подвійна уретероку- 


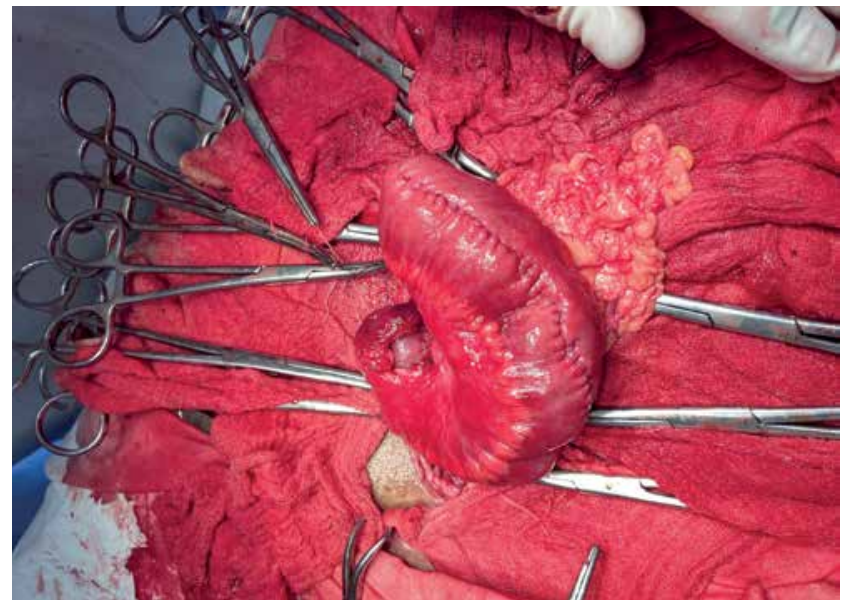

Рис. 2. Інтраопераційне фото. Сформований кишковий резервуар на судинній ніжці, підготовлений до анастомозу з сечовим міхуром
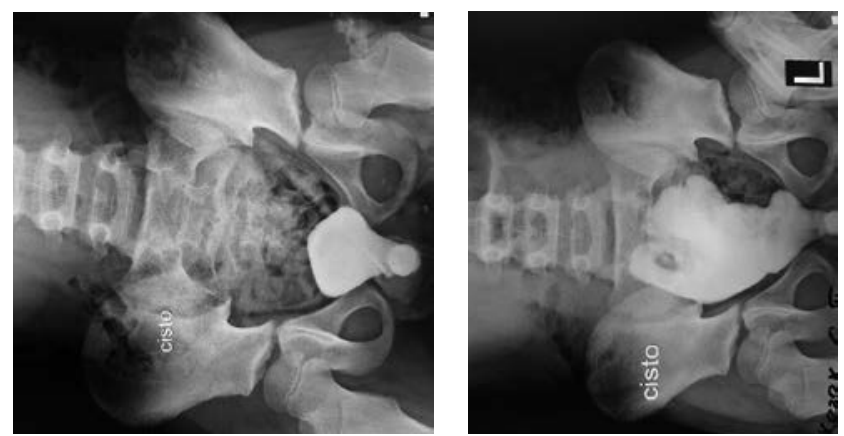

Рис. 4. Цистограми дитини до (ліворуч) та після (праворуч) аугментаційної ілеоцистопластики

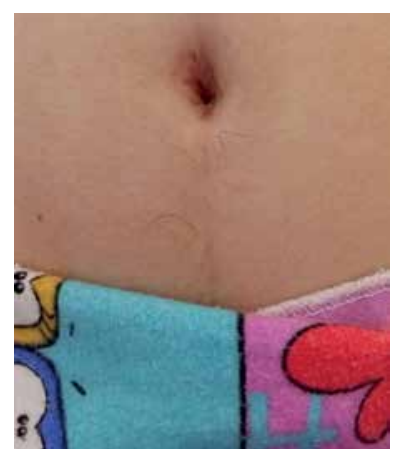

A

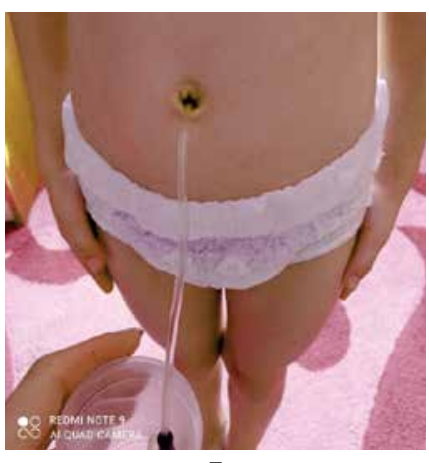

Б
Рис. 5. Вигляд пупка пацієнтки з апендикоумбілікоцистостомою (А); катетеризація сечового міхура через апендикоцистостому (Б)

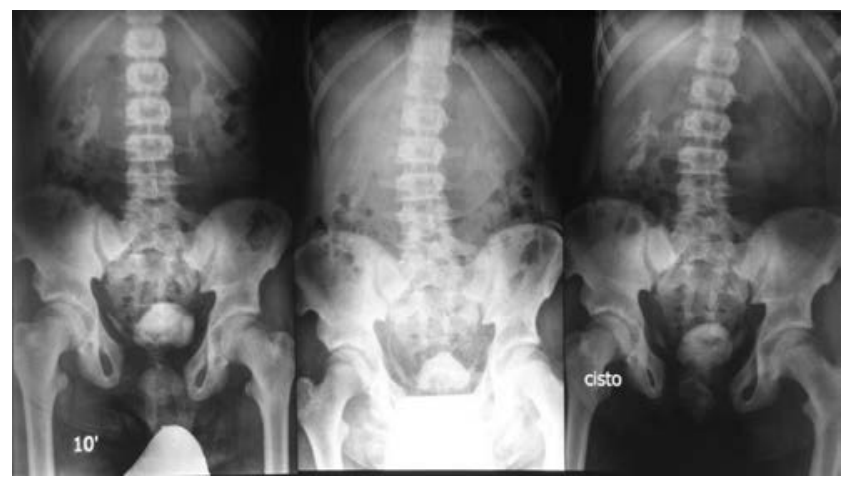

Рис. 6. Екскреторні урограми та мікційна цистограма хворого Б. Ознаки двобічного МСР, мікроцисту

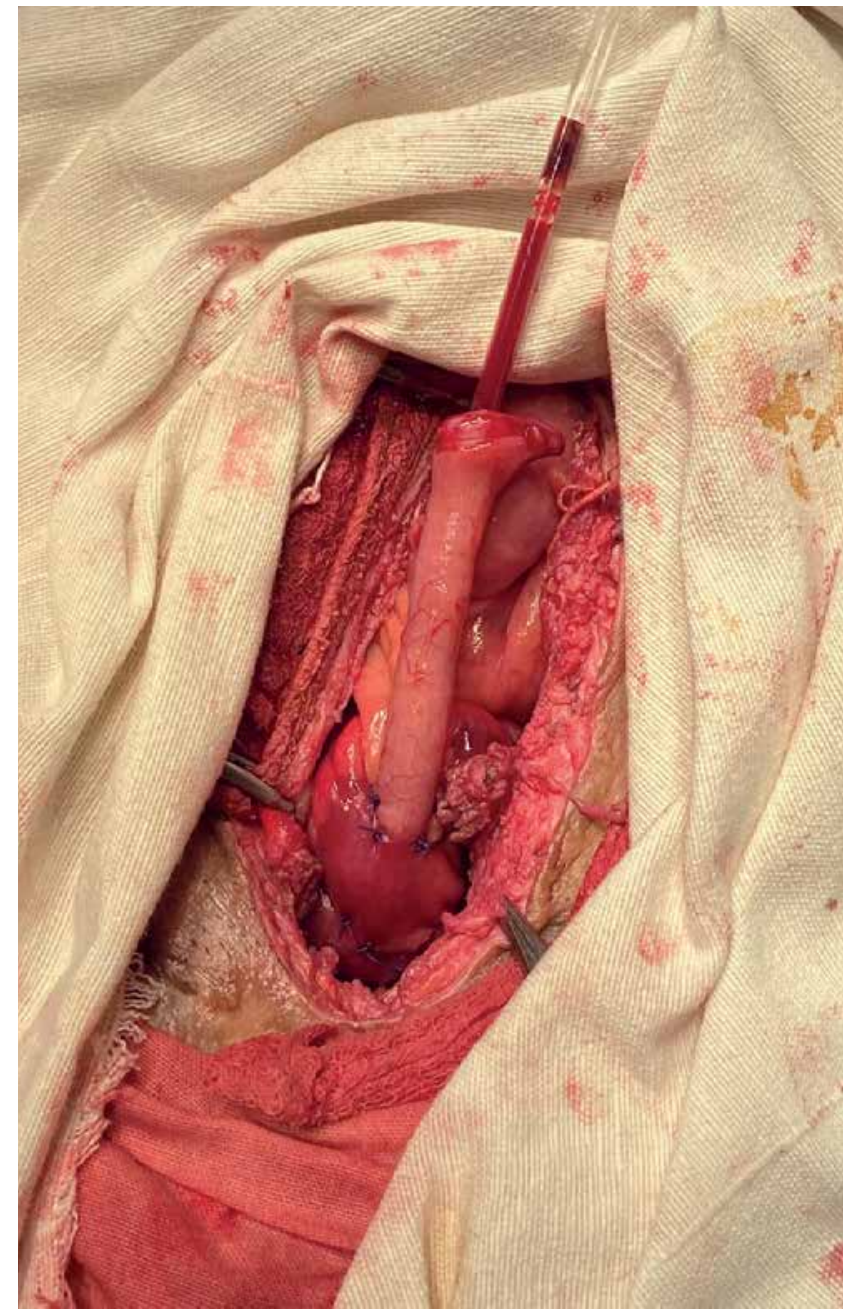

Рис. 3. Інтраопераційне фото. Апендикс імплантовано в кишкову частину неоцисту після аугментації з формуванням антирефлюксного підслизового каналу (відмічено стрілкою)

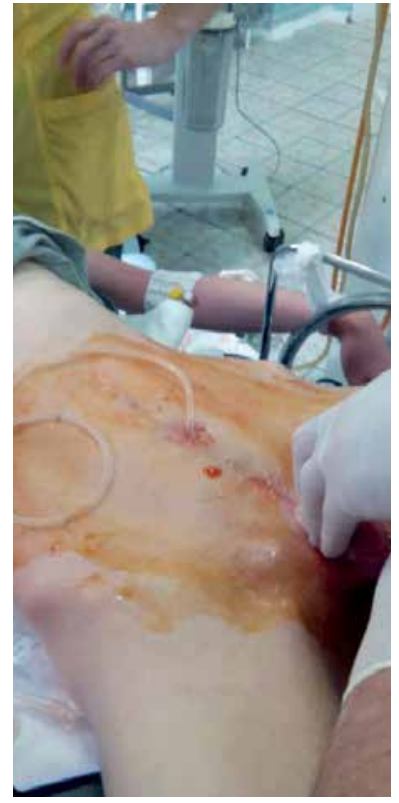

Рис. 7. Катетеризація сечового міхура через апендикоцистостому

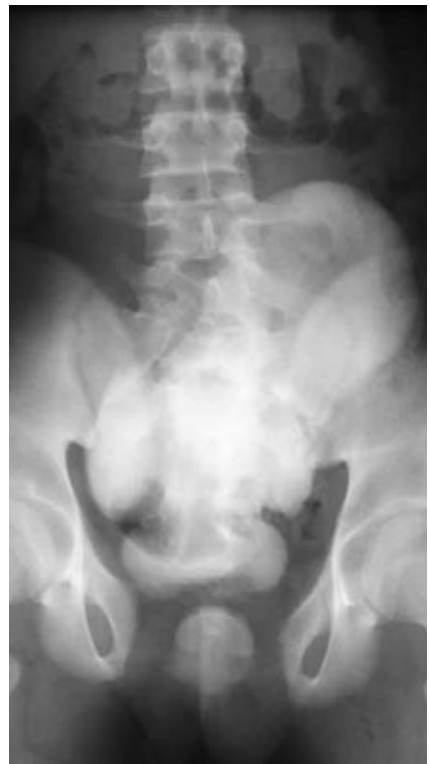

Рис. 8. Цистограма хворого Б., проведена через апендикоцистостому, 6 міс після операції 
танеостома у зв’язку зі швидким прогресуванням розширення порожнистих відділів обох нирок. Дитині виконали реконструктивно-пластичну операцію: ліквідація уретерокутанеостоми, уретероуретеростомія (кінець лівого сечоводу в бік правого), реімплантація правого сечоводу в сечовий міхур, апендикоцистоумбілікостомія. Повноцінний антирефлюксний механізм створеного вічка сечоводу і апендикостоми забезпечити не вдалося через виражені склеротичні зміни сечового міхура. Тому хворій наступним етапом запланували провести АЦП зі створенням повноцінних антирефлюксних механізмів.

Під час вивчення катамнезу значну увагу приділили оцінці якості життя оперованих дітей. Для цього провели анкетування оперованих дітей та їхніх батьків, у якому відображена інформація про стан утримання сечі, частоту самокатетеризації міхура, наявність підтікання сечі через уретру, наявність інфекцій сечових шляхів, фізичний та психологічний стан дітей, їх задоволеність проведеним хірургічним втручанням. У зв'язку з незначною кількістю спостережень статистичну обробку результатів анкетування не проводили. Однак за результатами анкетування виявили поліпшення більшості параметрів якості життя оперованих хворих. Особливе задоволення в дітей та їхніх батьків відмітили у зв'язку з «сухістю» пацієнтів, відсутністю потреби в носінні підгузників, відсутністю неприємного запаху від дітей, більш рідкісним і контрольованим сечовипусканням, можливістю відвідування дитячих колективів та соціальною адаптацією цих дітей у суспільстві.

Для ілюстрації ефекту хірургічної реконструкції ДСШ наводимо клінічне спостереження. Хворий 5 ., хлопчик, 14 років 2 місяці, надійшов до Івано-Франківської ОДКЛ 18.09.2017. Діагноз «Екстрофія сечового міхура, стан після операції. Мікроцист. Парадоксальна ішурія. Двобічний МСР I-III ст. Епіспадія. Вторинний хронічний пієлонефрит. Нориця уретри. Аплазія крижових кісток. Недостатність тазового кільця».

Хворіє від народження. Неодноразово оперований у різних клініках з приводу екстрофії сечового міхура, епіспадії, двобічного крипторхізму, злукової кишкової непрохідності, орхіту, уретральної нориці. Хворий відстає у фізичному і статевому розвитку, має знижену масу тіла. Сечу не утримує. Багаторазові спроби гідродилатації сечового міхура та інші консервативні методи лікування не давали ефекту. На шкірі надлобкової ділянки та промежини - виражена мацерація від постійного витікання сечі.
За результатами ультразвукового дослідження: сечовий міхур різко зменшений у розмірах (об’єм до 30 мл), стінки його нееластичні, ущільнені. Гідрокалікоз з обох боків. При мікційній цистоскопії: ознаки двобічного МСР, мікроцисту (рис. 6).

25.09.2017 проведено операцію під загальним знеболюванням (хірург - професор Фофанов О.Д.): лапаротомія, аугментаційна ілеоцистопластика, апендикоцистоумбілікостомія з антирефлюксним захистом за Mitrofanoff, ушивання шийки сечового міхура. Під час операції проведено адгезіолізис через виражений злуковий процес. Взято трансплантат здухвинної кишки довжиною 45 см, на відстані 15 см від ілеоцекального кута на судинній ніжці. Однорядний ілеоілеоанастомоз. Проведено детубуляризацію трансплантата зі складанням отриманого клаптя здухвинної кишки двічі у взаємно перпендикулярних напрямках, сформовано сферичної форми мішок. Проведено везикотомію верхньої стінки від правого до лівого боку. Виконано відкриту підслизову імплантацію об'ємоутворюючого гелю у вічка обох сечоводів. Також ушито шийку сечового міхура. Мобілізація сліпої кишки, виділено апендикс на судинній ніжці, відсічено його верхівку. По задній стінці міхура накладено апендиковезикоанастомоз, проводячи відросток через підслизовий тунель стінки міхура довжиною 2,5 см для антирефлюксного захисту. Оскільки у хворого не було пупка після попередніх операцій, проведено умбілікопластику і формування апендикостоми через сформований пупок. Клапоть тонкої кишки вшито в сечовий міхур однорядним безперервним швом (Vicryl № 3-0). Епіцистостомія. Перивезикально - трубчастий дренаж.

Післяопераційний перебіг - без ускладнень. Апендикостома катетеризується добре, клапан працює добре, підтікання сечі немає (рис. 7).

Пізніше виникло підтікання сечі через уретру при переповненні міхура. Підтікання ліквідовано шляхом ендоскопічної підслизової ін'єкції гелю в шийку міхура. За 6 місяців після операції проведено цистографію і цистоскопію через апендикостому - об'єм міхура понад 250 мл. МСР немає (рис. 8). Стан нирок і сечоводів, за даними ультрасонографії та екскреторної урографії, задовільний. Хворий перебуває під спостереженням 3 роки 10 місяців. Почувається добре. Епізодів інфекції сечових шляхів немає. Сечопуск контрольований, шляхом самокатетеризації 4-5 разів на добу. Підтікання сечі немає. Періодично відмиваються клубки слизу з міхура. Фізичний розвиток відповідає віку. За даними біохімічного дослідження крові, метаболічних порушень у дитини не виявлено. 
Наведене клінічне спостереження показує типову патологію, при якій $є$ абсолютні показання до АЦП, поєднаної з операцією Mitrofanoff та ушиванням шийки сечового міхура. У результаті складної хірургічної реконструкції ДСШ у хворого досягнуто головної мети лікування - створено достатній за об'ємом сечовий міхур, забезпечено утримання сечі, контрольоване сечовипускання, вилікувано МСР та хронічний пієлонефрит. Це суттєво поліпшило якість життя дитини.

\section{Висновки}

Виходячи з першого власного досвіду проведення аугментаційної ілеоцистопластики та апендикоцистостомії за Mitrofanoff, відмічено добрий ефект цих реконструктивно-пластичних операцій. У всіх оперованих хворих істотно поліпшилася якість життя - досягнуто контрольованого сечопуску, припинено прогресування ушкодження нирок. Усі післяопераційні ускладнення успішно корегуються. Велике значення для досягнення доброго ефекту лікування має правильний вибір обсягу хірургічної реконструкції сечових шляхів у кожному конкретному випадку.

\section{Перспективи подальших досліджень}

Зважаючи на значну кількість дітей з тяжкою дисфункцією сечового міхура, які мають потребу в АЦП i/або апендикоцистостомії, ці операції слід виконувати частіше. Операцію за принципом Mitrofanoff доцільно широко впроваджувати не тільки у хворих з урологічною патологією, але й серед дітей з патологією центральної нервової системи, які мають стійке нетримання сечі.

Автори заявляють про відсутність конфлікту інтересів.

\section{References/Лiтература}

1. Altaweel W, Jednack R, Bilodeau C, Corcos J. (2006). Repeated intradetrusor botulinum toxin type A in children with neurogenic bladder due to myelomeningocele. J Urol. 175: 1102-1105.
2. Atta CAM, Fiest KM, Frolkis AD, Jette N, Pringsheim T, St Germaine-Smith C et al. (2016). Global birth prevalence of spina bifida by folic acid fortification status: a systematic review and meta-analysis. Am J Public Health. 106: 24-34.

3. Averin VI. (2015). Surgical rehabilitation of children with urinary incontinence. Surgery. Eastern Europe. 3: 61-67. [Аверин ВИ. (2015). Хирургическая реабилитация детей с недержанием мочи. Хирургия. Восточная Европа. 3: 61-67].

4. Averin VI. (2019). Intestinal plastic of the bladder in patients with lower urinary tract pathology. Pediatrics: yesterday, today, tomorrow: materials of scientific-practical. conf., dedicated. 55th anniversary of the pediatrician faculty. Under scientific. Ed. V.I. Bobrovnicheva. Minsk: BSMU: 34-36. [Аверин ВИ. (2019). Кишечная пластика мочевого пузыря у пациентов с патологией нижних мочевых путей. Педиатрия: вчера, сегодня, завтра: материалы науч.-практ. конф., посвящ. 55-летию педиатр. фак-та, Белорус. гос. мед. ун-т. Под науч. ред. В. И. Бобровничева. Минск: БГМУ: 34-36].

5. Gor RA, Elliott SP. (2017). Surgical management of neurogenic lower urinary tract dysfunction. Urol Clin North Am. 44: 475-490.

6. Hoen L, Ecclestone H, Blok BFM, Karsenty G, Phé V, Bossier R et al. (2017). Long-term effectiveness and complication rates of bladder augmentation in patients with neurogenic bladder dysfunction: a systematic review. Neurourol Urodyn. 36: 1685-1702.

7. Langer S, Radtke C, Györi E, Springer A, Metzelder ML. (2019). Bladder augmentation in children: current problems and experimental strategies for reconstruction. Wiener Medizinische Wochenschrift. 169: 61-70.

8. Lapides J, Diokno AC, Gould FR, Lowe BS. (1976). Further observations on self-catheterization. J Urol. 116: 169-171.

9. Lee B, Featherstone N, Nagappan P, McCarthy L, O’Toole S. (2016). British Association of Paediatric Urologists consensus statement on the management of the neuropathic bladder. J Pediatr Urol. 12: 76-87. doi: 10.1016/j.jpurol.2016.01.002.

10. Mitrofanoff P. (1980). Trans-appendicular continent cystostomy in the management of the neurogenic bladder. Chir Pediatr. 21: 297-305.

11. Monti PR, Lara RC, Dutra MA, de Carvalho JR. (1997). New techniques for construction of efferent conduits based on the Mitrofanoff principle. Urology. 49: 112-115. doi: 10.1016/S00904295(96)00503-1.

12. Nseyo U, Santiago-Lastra Y. (2017). Long-term complications of the neurogenic bladder. Urol Clin North Am. 44: 355-366.

13. Stein R, Bogaert G, Dogan HS, Hoen L, Kocvara R, Nijman RJM. (2020). EAU/ESPU guidelines on the management of neurogenic bladder in children and adolescent part II operative management. Neurourol Urodyn. 39: 498-506.

14. Tudor KI, Sakakibara R, Panicker JN. (2016). Neurogenic lower urinary tract dysfunction: evaluation and management. J Neurol. 263: $2555-2564$.

\footnotetext{
Відомості про авторів:

Фофанов Олександр Дмитрович - д.мед.н., проф., зав. каф. дитячої хірургії Івано-Франківського НМУ. Адреса: м. Івано-Франківськ, вул. В. Касіяна, 24; тел./факс (0342) 52-56-49. https://orcid.org/0000-0003-1437-4161.
}

Юриева Алевтина Петрівна - д.мед.н., проф. каф. педіатрії Івано-Франківського Нму. Адреса: м. Івано-Франківськ, вул. Є. Коновальия, 132. https://orcid.org/0000-0001-8294-3464.

Зіняк Богдан Михайлович - лікар-дитячий уролог КНП «Івано-Франківська обласна дитяча клінічна лікарня Івано-Франківської обласної ради». Адреса: м. Івано-Франківськ, вул. Є. Коновальия, 132.

Доценко Юрій Романович - лікар-дитячий уролог КНП «Івано-Франківська обласна дитяча клінічна лікарня Івано-Франківської обласної ради». Адреса: м. Івано-Франківськ, вул. Є. Коновальия, 132.

Фофанов Вячеслав Олександрович - асистент каф. педіатрії післядипломної освіти Івано-Франківського НМУ, лікар-дитячий хірург. Адреса: м. Івано-Франківськ, вул. Є. Коновальия, 132. https://orcid.org/0000-0002-1524-7669.

Стаття надійшла до редакції 26.06.2021 р., прийнята до друку 8.09.2021 p. 
К.Ю. Пащенко, Н.В. Рой

\title{
Етапна лапароскопічна тракційна орхіопексія за Shehata: перший досвід, технічні особливості, результати
}

\author{
Харківський національний медичний університет, Украйна
}

Paediatric surgery.Ukraine.2021.3(72):51-55; doi 10.15574/PS.2021.72.51

For citation: Pashchenko KYu, Roi NV. (2021). Staged laparoscopic traction orchiopexy by Shehata: first experience, technical features, results. Paediatric Surgery. Ukraine. 3(72):51-55; doi 10.15574/PS.2021.72.51.

Мета - оцінити результати запропонованої методики етапної лапароскопічної тракційної орхіопексії за Shehata на основі власного досвіду лікування дітей з абдомінальним крипторхізмом.

Матеріали та методи. За період 2019-2021 рр. за методикою етапної лапароскопічної тракційної орхіопексії прооперовано 18 хлопчиків віком від 9 міс. до 4 років. Правобічний унілатеральний абдомінальний крипторхізм виявлено в 10 дітей, лівобічний - у 6, білатеральний - у 2. Показаннями до застосування методу стали випадки внутрішньочеревної тестикулярної ретенції з короткими судинами.

Результати. Тазові та клубові ретенції спостерігалися у 44\% випадках. У 22\% дітей яєчка локалізувалися безпосередньо біля входу до внутрішнього пахового кільця, у $33 \%$ дистанція між яєчком та отвором пахового каналу сягала 3-4 см. На першому етапі проводилася мобілізація яєчка та судин з фіксаційною тракцією у контрлатеральний бік. Другий етап здійснювався за 3 міс потому. У 94\% дітей на другому етапі вдалося провести вдалу орхіопексію без натягу судин. Жодного випадку дислокації або атрофії яєчок не зафіксовано. Об’єм низведеного яєчка в 78\% випадків був об’єктивно меншим за здорове.

Висновки. Досвід виконання операції Shehata свідчить про хороший ефект цього методу для лікування абдомінального крипторхізму. Показаннями до етапної лапароскопічної тракційної орхіопексії є внутрішньочеревні форми крипторхізму з недостатньюю довжиною тестикулярних судин. Методика дає змогу за короткий період досягти ефективної елонгації судин яєчка та мінімізувати ризики його атрофічних змін порівняно з двоетапною операцією Fowler-Stephens.

Дослідження виконано відповідно до принципів Гельсінської декларації. Протокол дослідження ухвалено Локальним етичним комітетом зазначеної в роботі установи. На проведення дослідження отримано інформовані згоди батьків дітей.

Автори заявляють про відсутність конфлікту інтересів.

Ключові слова: абдомінальний крипторхізм, орхіопексія, етапне лікування, операція Shehata.

\section{Staged laparoscopic traction orchiopexy by Shehata: first experience, technical features, results \\ K.Yu. Pashchenko, N.V. Roi}

Kharkiv National Medical University, Ukraine

Purpose - to evaluate the results of proposed method of staged laparoscopic traction orchiopexy by Shehata on the basis of our own experience in the treatment of children with abdominal cryptorchidism.

Materials and methods. During the period 2019-2021, 18 boys aged 9 months -4 years were operated with staged laparoscopic traction orchiopexy procedure. Right unilateral abdominal cryptorchidism observed in 10 children, left - in 6, bilateral - in 2 . Indications for the procedure were cases of intra-abdominal testicular retention with short vessels.

Results. Pelvic and iliac retentions observed in $44 \%$ of cases. In $22 \%$ testicles were located close to the inner inguinal ring, in $33 \%$ the distance between testicle and inguinal canal opening reached $3-4 \mathrm{~cm}$. The 2 nd stage was carried out in 3 months. Successful orchiopexy was conducted then in $94 \%$ cases without any vascular tension. No cases of testicular dislocation or atrophy have been reported. The volume of operated testicles was smaller than the healthy ones in $78 \%$ cases objectively.

Conclusions. The experience of Shehata operation showed good effect of the method for correction of abdominal cryptorchidism. Indications for staged laparoscopic traction orchiopexy are abdominal undescended testicles with insufficient length of vessels. The technique allows to achieve effective elongation of spermatic vessels in a short period of time and to minimize the risks of atrophy, compared with the 2-stage Fowler-Stephens operation. 
This study was conducted in accordance with the principles of the Helsinki Declaration. The research protocol was approved by the Local Ethics Committee of the institution mentioned in the work. Informed parental agreement was obtained for the research.

No conflict of interests was declared by the authors.

Key words: abdominal cryptorchidism, orchiopexy, staged treatment, Shehata procedure.

\section{Этапная лапароскопическая тракционная орхиопексия по Shehata: первый опыт, технические осо- бенности, результаты \\ К.Ю. Пащенко, Н.В. Рой}

Харьковский национальный медицинский университет, Украина

Цель - оценить результаты предложенной методики этапной лапароскопической тракционной орхиопексии по Shehata на основе собственного опыта лечения детей с абдоминальным крипторхизмом.

Материалы и методы. За период 2019-2021 гг. методом этапной лапароскопической тракционной орхиопексии прооперированы 18 мальчиков в возрасте от 9 мес. до 4 лет. Правосторонний унилатеральный абдоминальный крипторхизм выявлен у 10 детей, левосторонний - у 6 , билатеральный -у 2. Показаниями к использованию методики были случаи внутрибрюшной тестикулярной ретенции с короткими сосудами.

Результаты. Тазовые и подвздошные ретенции наблюдались в 44\% случаях. У 22\% детей яички находились непосредственно у внутреннего пахового кольца, в 33\% случаев дистанция между ним и яичком составляла 3-4 см. На первом этапе проводилась мобилизация яичка и сосудов с фиксационной тракцией на контрлатеральную сторону. Второй этап выполнялся через 3 мес. У 94\% детей на втором этапе удалось провести удачную орхиопексию без натяжения сосудов. Случаев дислокации или атрофии яичек не зафиксировано в послеоперационном периоде. Объем низведенного яичка в $78 \%$ случаев был объективно меньше здорового.

Выводы. Опыт выполнения операции Shehata свидетельствует о хорошем эффекте этого метода для лечения абдоминального крипторхизма. Показаниями к этапной лапароскопической тракционной орхиопексии являются внутрибрюшные формы крипторхизма с недостаточной длиной тестикулярных сосудов. Методика позволяет за короткий период достичь эффективной элонгации сосудов яичка и минимизировать риски его атрофических изменений по сравнению с двухэтапной операцией Fowler-Stephens.

Исследование выполнено в соответствии с принципами Хельсинкской декларации. Протокол исследования одобрен Локальным этическим комитетом указанного в работе учреждения. На проведение исследования получено информированное согласие родителей пациентов.

Авторы заявляют об отсутствии конфликта интересов.

Ключевые слова: абдоминальный крипторхизм, орхиопексия, этапное лечение, операция Shehata.

\section{Вступ}

Абдомінальний крипторхізм (АК) - вроджена вада розвитку зовнішніх статевих органів у хлопчиків, при якій яєчка залишаються ретенованими в черевній порожнині [5].

Високі черевні форми крипторхізму є технічно непростим завданням для хірурга і великою соціальною проблемою для дитини та ії батьків у подальшому. Невдалі первинні або повторні спроби орхіопексії призводять до травматизації паренхіми яєчка, посилення його гіпоплазії та, як наслідок, до гіпогонадизму, інфертильності, необхідності в протезуванні та пожиттєвій гормонозамісній терапії в постпубертатному періоді. Візуальна відсутність двох яєчок у мошонці формує в хлопчика низку комплексів і фобій, а також проблем у сексуальному житті.

Важливим фактом залишається ризик малігнізації ретенованих яєчок, що, за даними літератури, підвищується до 5-10 разів [4,6]. Подальший динамічний скринінг стану низведеного яєчка необхідний пацієнтові протягом усього життя, адже навіть після успішної орхіопексії статистичні випадки онкопатології також вищі [4].

Відсутність яєчка при пальпації в ділянці пахового каналу є абсолютним показанням до лапароскопічної ревізії черевної порожнини. Методики, здебільшого застосовувані при АК хірургами більшості країн світу, - симультанна або двоетапна операції за Fowler-Stephens, а також мікроваскулярна аутотрансплантація [5,9]. При симультанній ко- рекції виконують лапароскопічну мобілізацію яєчка та судин на протязі, після чого проводять низведення та орхіопексію в мошонці. У разі, якщо після тотальної мобілізації тестикулярних судин і vas deferens довжина сім'яного канатика не дає змоги низвести яєчко у фізіологічну позицію, проводять лікування судин, залишаючи яєчко на попередньому місці. Це роблять, щоб уникнути вторинної атрофії внаслідок перерозподілу кровопостачання, що далі забезпечують за рахунок коллатералів. За 8 міс потому класично проводять другий етап операції низведення та орхіопексію $[1,3,5]$. Недоліком двоетапної операції Fowler-Stephens, звичайно, $є$ редукція кровотоку, що збільшує ймовірність атрофії яєчка.

Мікроваскулярна аутотрансплантація - дуже складний спосіб лікування АК. Суть цієї методики полягає в розділенні тестикулярних судин і мікровазальному анастомозуванні артерії та вени яєчка 3 нижніми епігастральними судинами. Вказану методику практикують лише в поодиноких клініках, адже лапароскопічні способи орхіопексії значно легші технічно та ефективніші.

У 2008 р. єгипетський хірург Sameh Shehata запропонував нову методику лікування АК - етапну лапароскопічну тракційну орхіопексію (ЕЛТО), що дає змогу зберегти природне кровопостачання та провести ефективну елонгацію тестикулярних судин, повністю зберігаючи природний кровообіг [8], а вже за кілька років накопичений досвід виконання цієї 
операції та результати катамнезу підтвердили іï хороший ефект [2,7] (рис. 1).

На першому етапі лапароскопічної ревізії черевної порожнини проводять мобілізацію яєчка та судин, після чого яєчко фіксують інтракорпоральним швом до контрлатерального боку внутрішньої поверхні передньої черевної стінки.

Другий етап операції виконують за 3 міс потому. Протягом цього періоду судини яєчка подовжуються за рахунок виконаної тракції та м'якої компресії судин перистальтичними рухами кишечника $[7,8]$. Яєчко відсікають від місця фіксації та низводять у мошонку.

Мета дослідження - оцінити результати запропонованої методики етапної лапароскопічної тракційної орхіопексії за Shehata на основі власного досвіду лікування дітей з АК.

\section{Матеріали та методи дослідження}

Протягом 2019-2021 рр. за методикою ЕЛТО прооперовано 18 хлопчиків з АК віком від 9 міс. до 4 років. Правобічний унілатеральний АК спостерігався у 10 дітей, лівобічний - у 6, білатеральний - у 2 випадках. Дітей прооперовано на базі КНП ХОР «Обласна дитяча клінічна лікарня № $1 »$ м. Харкова, а також в умовах приватного Центру дитячої хірургії $\Pi \Phi$ «Беатріс».

Діагностичну лапароскопію виконували в усіх випадках одно- чи двобічного крипторхізму за відсутності яєчка в паховій ділянці під час пальпації. Передопераційне обстеження за допомогою ультразвукового дослідження або магнітно-резонансної томографії зазвичай не проводили. Показаннями до ЕЛТО стали випадки внутрішньочеревної тестикулярної ретенції з короткими судинами, що не давали змоги проводити симультанну орхіопексію. У разі агенезії, аплазії та атрофії яєчка, оперативне лікування обмежували діагностичною лапароскопією або видаленням атрофованих судинних залишків. Дітям з білатеральним крипторхізмом обов'язково передопераційно призначали обстеження на каріотип.

Операції виконували з використанням «Full HD» оптики Karl Storz Hopkins II, 3 та 5 мм інструментами. Відеопорт встановлювали трансумбілікально, 2 порти для маніпуляцій у правому та лівому мезогастрії за принципом триангулярності.

Дослідження провели відповідно до принципів Гельсінської декларації. Протокол дослідження ухвалили Локальним етичним комітетом зазначеної в роботі установи. На проведення дослідження отримали інформовану згоду батьків дітей.

\section{Результати дослідження та їх обговорення}

Рекомендованими термінами хірургічної корекції крипторхізму вважається вік від 6 до 18 міс. У випадках АК вважаємо оптимальнішим період 10-12 міс. Це пов'язано з технічними особливостями лапароскопічної операції, адже маніпулятивний простір у черевній порожнині маленького пацієнта дуже обмежений, навіть за використання 3-міліметрових інструментів. Також певні складнощі виникають при встановленні портів унаслідок низького тонусу черевної стінки малюка та через обмежено допустимий тиск карбоксиперитонеуму. У разі встановлення портів у безпосередній близькості до внутрішнього пахового кільця (ВПК) проводити дисекцію важко. Це займає багато часу та супроводжується підвищеним ризиком ускладнень.

Хірургічне лікування починали з діагностичної лапароскопії. Високі (тазові та клубові) ретенції яєчок спостерігалися у 8 (44\%) випадках. У 4 (22\%) дітей ретеновані яєчка локалізувалися безпосередньо біля входу до ВПК, у 6 (33\%) хлопчиків дистанція між яєчком та ВПК сягала 3-4 см.

Важливим моментом на початку лапароскопії $\epsilon$ достатня експлорація нижніх відділів черевної порожнини. Якщо при встановленні оптичного порту не відмічаються тестикули, слід обов'язково провести відведення петель кишечника та ретельно візуалізувати малий таз і заочеревинний простір. У разі високої тазової або навіть здухвинної локалізації яєчок останні можуть залишитися невиявленими, якщо обмежитися лише поверхневим оглядом.
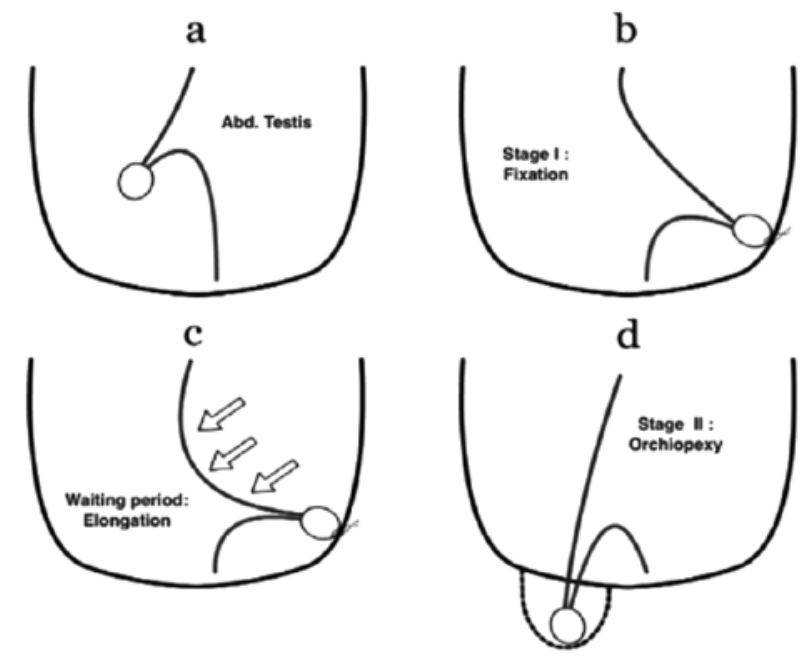

Рис. 1. Схематичне зображення етапної лапароскопічної тракційної орхіопексії за Shehata (а - позиція ретенованого яєчка в черевній порожнині; b - яєчко, фіксоване на протилежний бік до внутрішньої поверхні черевної стінки; селонгація судин яєчка під впливом тракції та перистальтики; d - другий етап операції, низведення та орхіопексія) 


\section{Оригінальні дослідження. Урологія та гінекологія}

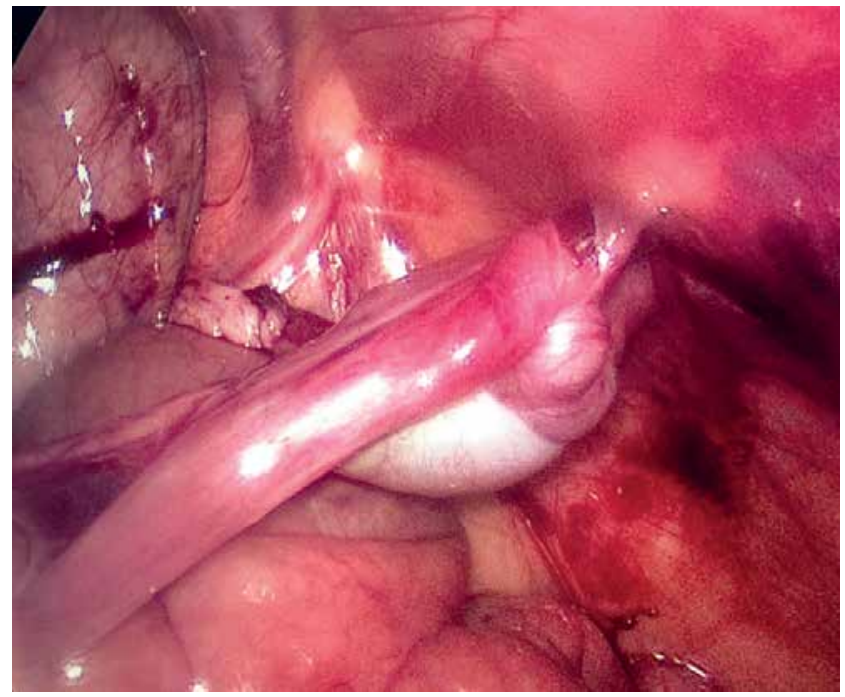

Рис. 2. Яєчко, фіксоване на контрлатеральний бік до черевної стінки

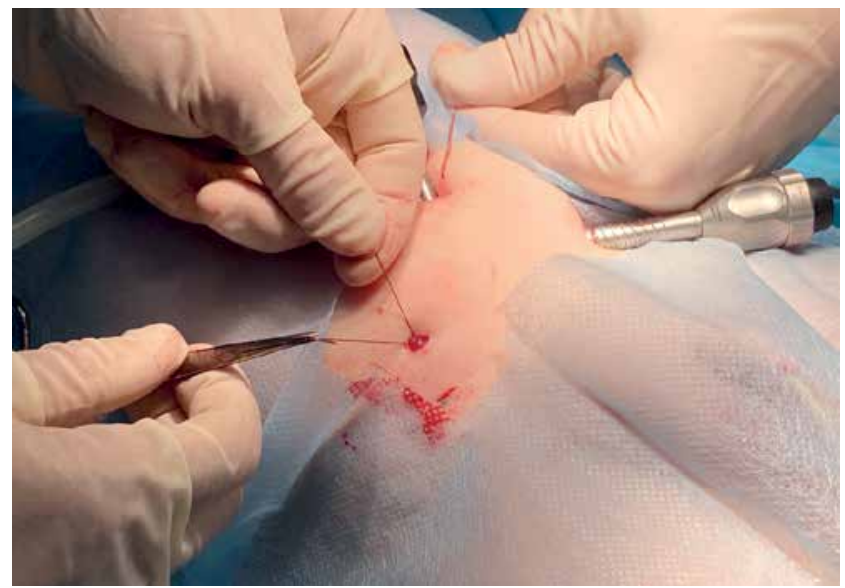

Рис. 3. Затягування тракційного шва на передній черевній стінці

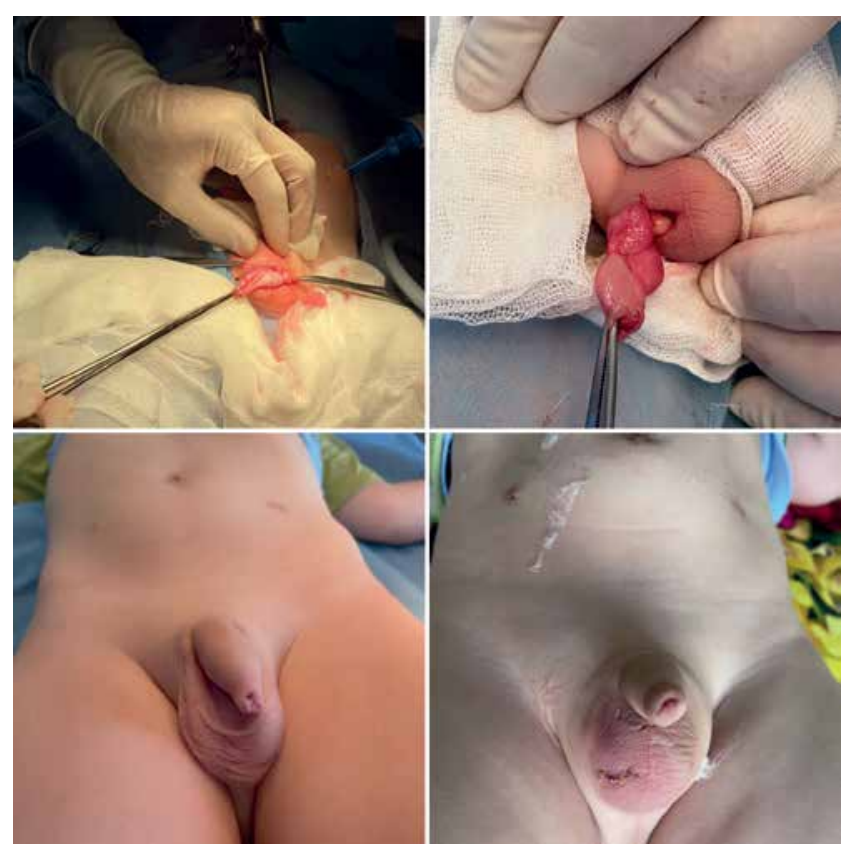

Рис. 4. Орхіопексія, другий етап Елто. Яєчко без натягу низводять у мошонку та фіксують
Після мобілізації губернакулюма та яєчка проводили повне відокремлення судин та сім'явивідної протоки від очеревини та фіксуючих злук. Після цього оцінювали можливість проведення орхіопексії. Якщо після закінчення мобілізації яєчко без натягу судин вільно доводилося до контрлатерального ВПК, виконували симультанну орхіопексію. Якщо ж ні, то проводили перший етап ЕЛТО (рис. 2).

За недостатньої довжини судин виконували прошивання яєчка інтракорпоральним швом і його тракцію в протилежний бік у напрямку здухвинної ділянки. Місце фіксації може варіюватися залежно від натягу судин, що слід враховувати для запобігання ятрогенній атрофії яєчка. Фіксуючий вузол затягували екстракорпорально.

Оптимальним місцем накладення тракційного шва на яєчко має бути край паренхіми, але не залишки губернакулюма, розміщені попереду. За перших спроб ЕЛТО ми зіткнулися з цією проблемою внаслідок браку досвіду. У разі фіксації за губернакулюм або на його межі з яєчком результатом стає значне веретеноподібне подовження першого, а тестикулярні судини не зазнають змін.

У деяких випадках інтракорпоральний шов не використовували. Після мобілізації яєчко підтягували за край паренхіми м'яким дисектором до контрлатерального порту. Порт видаляли, фіксаційний шов накладали на паренхіму яєчка одразу під дисектором. Далі завершували фіксацію на шкірі (рис. 3).

Цей маневр дав змогу скоротити час операції та полегшити її технічне виконання. Потім здійснювали оптичний контроль положення фіксованого яєчка для запобігання його торсії відносно сім'яного канатика.

Другий етап ЕЛТО здійснювали за 3 міс після первинного. За цей час вдається досягнути значної елонгації судин та в більшості випадків без натягу провести орхіопексію. Випадків атрофії яєчка після першого етапу ЕЛТО не виявили.

Під відеоконтролем яєчко відсікали від очеревини в місці попередньої фіксації. Низведення виконували через ВПК без додаткового доступу в паховій ділянці (13 випадків). Особливістю вторинного етапу ЕЛТО в деяких випадках стає відсутність чіткої візуалізації ВПК, що виникає після маніпуляцій у цій зоні на першому етапі. Топографічних орієнтирів у вигляді типово розташованих біля ВПК елементів сім'яного канатика, звичайно, також немає. У разі виникнення труднощів пошуку отвору пахового каналу слід орієнтуватися на анатомію контрлатеральної ділянки. При тупій дисекції в зоні зрощень ВПК сполучнотканинні злуки зазвичай легко розділяються та кільце 
візуалізується. Слід зазначити, що допустимим є низведення яєчка не крізь ВПК, але й найкоротшим шляхом над сечовим міхуром. Цей прийом дає змогу «виграти» зайві сантиметри для орхіопексії за недостатньої довжини судин, але супроводжується підвищеним ризиком травматизації сечового міхура та епігастральних судин.

У 5 (28\%) дітей додатково застосовували паховий розріз близько 2 см з розкриттям передньої стінки пахового каналу. Принципових відмінностей в успішності орхіопексії при цьому не відмічали, тому відмова від додаткового пахового доступу дала змогу заощадити час і зменшити загальну травматичність операції.

3 метою профілактики виникнення пахової кили зазвичай не проводять звужування ВПК. На власному досвіді лікування АК ми не спостерігали жодного випадку подібних ускладнень. Широкий вагінальний відросток частіше характерний для пахових форм крипторхізму або при операціях у дітей віком від 3-5 років. При цьому не буде помилкою за значного розширення ВПК провести додаткову PIRSманіпуляцію або інтракорпорально накласти 1-2 вузлові шви.

Орхіопексію проводили за Петривальські після підготовки місця в мошонці. Важливим моментом під час низведення яєчка $€$ контролювання положення сім'яного канатику. Обов'язково слід запобігати його торсії, щоб уникнути ішемії та атрофії як наслідку.

У 17 (94\%) випадках після другого етапу ЕЛТО вдалося низвести та зафіксувати яєчко в мошонці без натягу (рис. 4).

Лише в однієї дитини внаслідок помилкової фіксації за губернакулюм після повторної операції зберігався помірний натяг сім'яного канатика.

Катамнестичне спостереження пацієнтів здійснювали за 1, 6, 12 міс й далі щорічно. Жодного випадку дислокації яєчка, а також атрофії не відмічали. Об'єм низведеного яєчка в 78\% випадків був пальпаторно меншим порівняно зі здоровим, але це характерно для більшості випадків крипторхізму незалежно від його форми.

\section{ВИсновки}

Досвід виконання ЕЛТО за Shehata свідчить про успішність цього методу в лікуванні АК. Методика
$€$ технічно нескладною і не потребує багато часу для виконання як першого, так і другого етапів.

Отже, можна сформувати такі висновки:

Показаннями до ЕЛТО є форми АК, що супроводжуються недостатньою довжиною тестикулярних судин.

Методика ЕЛТО дає змогу протягом короткого періоду досягти ефективної елонгації судин яєчка.

Завдяки відмові від редукції магістрального кровообігу, ЕЛТО дозволяє мінімізувати ризики атрофічних змін ретенованого яєчка порівняно з двоетапною методикою Fowler-Stephens.

Автори заявляють про відсутність конфлікту інтересів.

\section{References/Лiтература}

1. Abdelhalim A, Chamberlin JD, Young I, Fahim M, Chuang KW, McAleer IM et al. (2019). Testicular Volume Changes in Laparoscopic Staged Fowler-Stephens Orchiopexy: Studying the Impact of Testicular Vessel Division. Urology. 27: 113-118. doi: 10.1016/j.urology.2019.01.030.

2. Abouheba MAS, Younis W, Elsokary A, Roshdy W, Waheeb S. (2019). Early Clinical Outcome of Staged Laparoscopic Traction Orchidopexy for Abdominal Testes. J Laparoendosc Adv Surg Tech A. 29 (4): 531-537. doi: 10.1089/lap.2018.0171.

3. Alam A, Delto JC, Blachman-Braun R, Wayne G, Mittal AG, Castellan M et al. (2017). Staged Fowler-Stephens and Singlestage Laparoscopic Orchiopexy for Intra-abdominal Testes: Is There a Difference? A Single Institution Experience. Urology. 101: 104-110. doi: 10.1016/j.urology.2016.09.060.

4. Cheng L, Albers P, Berney DM, Feldman DR, Daugaard G, Gilligan T, Looijenga LHJ. (2018). Testicular cancer. Nat Rev Dis Primers. 4 (1): 29. doi: 10.1038/s41572-018-0029-0.

5. Elder JS. (2016). Surgical Management of the Undescended Testis: Recent Advances and Controversies. Eur J Pediatr Surg. 26 (5): 418-426. doi: 10.1055/s-0036-1592197.

6. Loebenstein M, Thorup J, Cortes D, Clasen-Linde E, Hutson JM, Li R. (2020). Cryptorchidism, gonocyte development, and the risks of germ cell malignancy and infertility: A systematic review. J Pediatr Surg. 55 (7): 1201-1210. doi: 10.1016/j. jpedsurg.2019.06.023.

7. Shehata S, Shalaby R, Ismail M, Abouheba M, Elrouby A. (2016). Staged laparoscopic traction-orchiopexy for intraabdominal testis (Shehata technique): Stretching the limits for preservation of testicular vasculature. J Pediatr Surg. 51 (2): 211-215. doi: 10.1016/j.jpedsurg.2015.10.063.

8. Shehata SM. (2008). Laparoscopically assisted gradual controlled traction on the testicular vessels: a new concept in the management of abdominal testis. A preliminary report. Eur J Pediatr Surg. 18 (6): 402-406. doi: 10.1055/s-2008-1039028.

9. Yu C, Long C, Wei Y, Tang X, Liu B, Shen L et al. (2018). Evaluation of Fowler-Stephens orchiopexy for high-level intraabdominal cryptorchidism: A systematic review and metaanalysis. Int J Surg. 60: 74-87. doi: 10.1016/j.ijsu.2018.10.046.

Відомості про авторів:

Пащенко Костянтин Юрійович - к.мед.н., доц. каф. дитячої хірургї та дитячої анестезіології Харківського НМУ. Адреса: м. Харків, пр. Науки, 4. https://orcid.org/0000-0003-3855-6787.

Рой Наталія В'ячеславівна - к.мед.н., доц. каф. дитячої хірургії та дитячої анестезіології Харківського НМУ Адреса: м. Харків, пр. Науки, 4. https://orcid.org/0000-0001-6626-0145.

Стаття надійшла до редакції 18.06.2021 р., прийнята до друку 8.09.2021 p. 


\title{
И.М. Вешкурцева ${ }^{1,2}$, М.А. Аксельров ${ }^{1,2}$, В.А. Емельянова ${ }^{1,2}$, С.Н. Супрунец ${ }^{1,2}$, А.В. Столяр ${ }^{1}$, С.Н. Гордийчук ${ }^{1}$, К.А. Лебедева ${ }^{1}$, Е.П. Ашихмина ${ }^{1}$, А.Л. Баринов ${ }^{2}$ \\ Инфекции мочевых путей у новорожденных детей: микробный пейзаж и проблемы антибиотикорезистентности
}

\author{
${ }^{1}$ ФБОУ ВО Тюменский государственный медицинский университет Министерства \\ здравоохранения, Россия \\ ${ }^{2}$ ГБУЗ ТО «Областная клиническая больница № 2», г. Тюмень, Россия
}

Paediatric surgery.Ukraine.2021.3(72):56-62; doi 10.15574/PS.2021.72.56

For citation: Veshkurtseva IM, Akselrov MA, Emelyanova VA, Suprunets SN et al. (2021). Urinary tract infections in newborn children: microbial landscape and antibiotic resistance problems. Paediatric Surgery.Ukraine. 3(72):56-62; doi 10.15574/PS.2021.72.56

Инфекция мочевых путей - одна из самых распространенных бактериальных инфекций у детей, которая в 30\% случаев может быть первым проявлением у ребенка врожденных аномалий развития мочевых путей и нарушений уродинамики. Несвоевременные диагностика, начало терапии, выбор неадекватного противомикробного препарата увеличивает риски прогрессирования заболевания, развития нефросклероза и инвалидизации пациента.

Цель - изучить микробный пейзаж при инфекции мочевых путей, его антибиотикорезистентность у новорожденных детей с аномалиями развития мочевыделительной системы.

Материалы и методы. Проанализированы результаты микробиологического исследования мочи у новорожденных детей с инфекциями мочевых путей на фоне аномалий развития мочевых путей. Эти дети находились на лечении в отделениях реанимации и патологии новорожденных в период 2016-2020 гг.

Результаты. Основными возбудителями инфекций мочевых путей у новорожденных детей с аномалиями развития мочевыделительной системы являются Enterobacterales $(63,4 \%)$, в 13,8\% - продуценты бета-лактамаз расширенного спектра. Наибольшую активность в отношении Escherichia coli проявили цефоперазон / сульбактам, амикацин, меропенем и нитрофурантоин. В отношении остальных представителей порядка Enterobacterales высоко активен был только амикацин. Штаммы Enterococcus spp., выявленные в $20 \%$, в каждом четвертом случае были устойчивы к резервному ванкомицину. Представители неферментирующих грамотрицательных бактерий обнаружены в 6,4\% случаев, резистентность к основным титруемым антибиотикам колебалась от 44,4\% до $100 \%$.

Выводы. Основными возбудителями инфекций мочевых путей у новорожденных детей с аномалиями развития мочевыделительной системы являются представители порядка Enterobacterales, Enterococcus spp. и неферментирующие грамнегативные бактерии, которые характеризовались высокой резистентностью, в том числе и к антибиотикам резерва. Высокие показатели устойчивости выделенной микрофлоры затрудняют выбор эффективной антибактериальной терапии у данной категории пациентов и требуют в большинстве случаев комбинированной антибиотикотерапии.

Исследование выполнено в соответствии с принципами Хельсинкской декларации. Протокол исследования одобрен Локальным этическим комитетом всех участвующих учреждений. На проведение исследований получено информированное согласие родителей детей.

Авторы заявляют об отсутствии конфликта интересов.

Ключевые слова: новорожденные дети, инфекция мочевых путей, аномалии развития мочевых путей, антибиотикорезистентность. 
Urinary tract infections in newborn children: microbial landscape and antibiotic resistance problems I.M. Veshkurtseva ${ }^{1,2}$, M.A. Akselrov ${ }^{1,2}$, V.A. Emelyanova ${ }^{1,2}$, S.N. Suprunets ${ }^{1,2}$, A.V. Stolyar ${ }^{1}$, S.N. Gordiychuk ${ }^{1}$, K.A. Lebedeva ${ }^{1}$, E.P. Ashikhmina ${ }^{1}$, A.L. Barinov ${ }^{2}$

${ }^{1}$ Tyumen State Medical University, Russia

${ }^{2}$ Regional Clinical Hospital № 2, Tyumen, Russia

Urinary tract infection is one of the most common bacterial infections in children, which in $30 \%$ of cases may be the first manifestation of the presence of congenital malformations of the urinary tract and urodynamic disorders in a child. Late diagnosis, initiation of therapy, and the choice of an inadequate antimicrobial drug increase the risks of disease progression, development of nephrosclerosis and patient disability.

Purpose - to study the microbial landscape in urinary tract infections, its antibiotic resistance in newborns with anomalies in the development of the urinary system. Materials and methods. The results of microbiological examination of urine in newborns with urinary tract infections against the background of anomalies in the development of the urinary tract, which are being treated in intensive care units and neonatal pathology in the period 2016-2020, have been analyzed. Results. The main causative agents of urinary tract infections in newborns with anomalies of the urinary system are Enterobacterales (63.4\%), $13.8 \%$ are producers of extended spectrum beta-lactamases. Cefoperazone/sulbactam, amikacin, meropenem and nitrofurantoin were most active against Escherichia coli. In relation to other representatives of the order Enterobacterales, only amikacin was highly active. The strains of Enterococcus spp., Detected in $20 \%$, were resistant to reserve vancomycin in every fourth case. Representatives of non-fermenting gram-negative bacteria were found in $6.4 \%$ of cases, resistance to the main titrated antibiotics ranged from $44.4 \%$ to $100 \%$.

Conclusions. The main causative agents of urinary tract infections in newborns with anomalies of the urinary system are representatives of the order Enterobacterales, Enterococcus spp. and non-fermenting gram-negative bacteria, which were characterized by high resistance, including to reserve antibiotics. The high indices of resistance of the isolated microflora make it difficult to choose an effective antibacterial therapy in this category of patients and in most cases requires combined antibiotic therapy.

The research was carried out in accordance with the principles of the Helsinki declaration. The study protocol was approved by the Local ethics committee of all participating institution. The informed consent of the patient was obtained for conducting the studies.

No conflict of interest was declared by the authors.

Key words: Urinary tract infection, newborn babies, urinary tract abnormalities, antibiotic resistance.

\section{Інфекції сечових шляхів у новонароджених дітей: мікробний пейзаж і проблеми антибіотикорези- стентності}

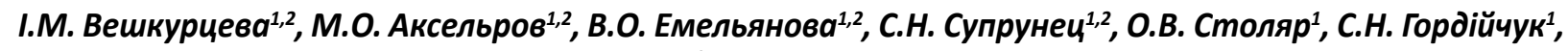
К.О. Лебєдєва ${ }^{1}$, О.П. Ашихміна ${ }^{1}$, О.Л. Барінов ${ }^{2}$

${ }^{1}$ Тюменський державний медичний університет МОЗ, Росія

${ }^{2}$ Міська клінічна лікарня № 2, м. Тюмень, Росія

Інфекція сечових шляхів - одна з найпоширеніших бактерійних інфекцій у дітей, що в 30\% випадків може бути першим проявом у дитини природжених аномалій розвитку сечових шляхів і порушень уродинаміки. Несвоєчасні діагностика, початок терапії, вибір неадекватного протимікробного препарату збільшують ризики прогресування захворювання, розвитку нефросклерозу й інвалідизації пацієнта.

Мета - вивчити мікробний пейзаж при інфекції сечових шляхів, його антибіотикорезистентність у новонароджених дітей з аномаліями розвитку сечовивідної системи.

Матеріали та методи. Проаналізовано результати мікробіологічного дослідження сечі в новонароджених дітей з інфекціями сечових шляхів на тлі аномалій розвитку сечових шляхів. Ці діти перебували на лікуванні у відділеннях реанімації і патології новонароджених у період 2016-2020 рр. Результати. Основними збудниками інфекцій сечових шляхів у новонароджених дітей з аномаліями розвитку сечовивідної системи $\epsilon$ Enterobacterales $(63,4 \%)$, у 13,8\% - продуценти бета-лактамаз розширеного спектра. Найбільшу активність щодо Escherichia coli виявили цефоперазон / сульбактам, амікацин, меропенем і нітрофурантоїн. Щодо інших представників порядку Enterobacterales високо активний був тільки амікацин. Штами Enterococcus spp., виявлені у 20\%, у кожному четвертому випадку були стійкі до резервного ванкоміцину. Представники грамнегативних бактерій, що не ферментують, виявлялися в 6,4\% випадків, резистентність до основних титрованих антибіотиків коливалася від 44,4\% до 100\%.

Висновки. Основними збудниками інфекцій сечових шляхів у новонароджених дітей з аномаліями розвитку сечовивідної системи $є$ представники порядку Enterobacterales, Enterococcus spp. і неферментативні грамнегативні бактерії, що характеризувалися високою резистентністю, у тому числі до антибіотиків резерву. Високі показники стійкості виділеної мікрофлори ускладнюють вибір ефективної антибактеріальної терапії в цієї категорії пацієнтів і потребує здебільшого комбінованої антибіотикотерапії.

Дослідження виконано відповідно до принципів Гельсінської декларації. Протокол дослідження ухвалено Локальним етичним комітетом усіх зазначених у роботі установ. На проведення досліджень отримано інформовану згоду батьків дітей.

Автори заявляють про відсутність конфлікту інтересів.

Ключові слова: новонароджені діти, інфекція сечових шляхів, аномалії розвитку сечових шляхів, антибіотикорезистентність.

Инфекция мочевых путей (ИМП) - одна из самых распространенных бактериальных инфекций у детей, которая в $30 \%$ случаев может быть первым проявлением наличия у ребенка малых или больших врожденных аномалий развития мочевых путей (АРМП) и нарушений уродинамики $[7,13,23]$.

Заболеваемость ИМП в общей популяции новорожденных детей составляет 0,1-2\%, возрастая до $13 \%$ у детей из группы риска, особенно у недоношенных и маловесных при рождении [2,5], и до 25\% при нахождении новорожденных в отделении реа- нимации и в постреанимационном периоде [3]. На долю ИМП в структуре заболеваний органов мочевыделительной системы у этой возрастной группы приходится в среднем 37,3\% [3].

Установлено, что в 90,3\% случаев в основе развития пиелонефрита у новорожденных и детей грудного возраста лежат морфологические аномалии развития мочевого тракта $[4,12]$. Обструктивные уропатии - наиболее часто встречающиеся пороки органов мочевой системы. Их доля составляет до 50\% всех пренатально выявляемых врождённых 


\section{Таблица 1}

Основные уропатогены, выделенные у новорожденных детей с инфекцией мочевых путей на фоне аномалий развития мочевых путей (\%)

\begin{tabular}{|l|l|l|}
\hline Уропатогены & $\%$ & Продуценты БЛРС \\
\hline Bсе представители семейства Enterobacterales & 63,5 & 13,8 \\
\hline Escherichia coli & 43,0 & 13,5 \\
\hline Enterobacter spp. & 10,5 & 16,7 \\
\hline Klebsiella pneumoniae & 7,0 & 8,3 \\
\hline Citrobacter spp. & 2,4 & 25,0 \\
\hline Proteus mirabilis & 0,6 & 0 \\
\hline Enterococcus spp. & 20,0 & - \\
\hline Staphylococcus aureus & 2,4 & - \\
\hline CoNS & 10,5 & - \\
\hline Pseudomonas aeruginosa & 5,2 & - \\
\hline Acinetobacter baumannii & 1,2 & - \\
\hline
\end{tabular}

пороков развития (ВПР) выделительной системы. Нарушение уродинамики при обструкции, присутствующее длительно и нарушающее отток мочи из почечной лоханки, приводит к поражению почечной паренхимы. Основными клиническими проявлениями обструктивной нефропатии являются инфекции мочевого тракта и тубулоинтерстициальный нефрит [11,21].

Особенностью заболеваний почек у новорожденных и детей грудного возраста является наличие морфологической незрелости почечной ткани, недифференцированность нефронов в функциональном отношении, что создает условия для развития инфекционно-воспалительного процесса с более высокой вероятностью развития уросепсиса [23]. У данной категории детей специфичных клинических проявлений ИМП нет, что затрудняет диагностику данной патологии и своевременность назначения адекватной антибактериальной терапии $[4,12,14]$. Заподозрить патологию можно по таким косвенным признакам, как «пологая» весовая кривая, отставание в физическом развитии, желтуха, дисфункция желудочно-кишечного тракта, гипервозбудимость, субнормальная температура тела $[2,7,16]$. Несвоевременное начало лечения увеличивает риски прогрессирования заболевания, развития нефросклероза и инвалидизации пациента, особенно при наличии у ребенка врожденных АРМП и нарушений уродинамики [9,23]. В виду неспецифичности течения ИМП, высокой вероятности развития нозокомиальных инфекций при проведении инвазивных исследований выявление данной патологии у новорожденных и детей грудного возраста возможно в основном благодаря клинико-лабораторному обследованию, особенно пациентов из группы риска (с признаками ВПР мочевой системы).
К данным методам диагностики относится и микробиологическое исследование мочи с определением этиологически значимых уропатогенов и их чувствительности к антибактериальным средствам [8], спектр которых и их резистентность меняются не только с течением времени, но и могут существенно различаться от региона к региону [15].

В настоящее время чувствительность подавляющего большинства уропатогенов к антибактериальным средствам не превышает $80 \%$, что связано с ростом продукции бета-лактамаз расширенного спектра (БЛРС) и карбапенемаз $[1,10,18,19]$, и является поводом для постоянного обновления рекомендаций по лечению ИМП с учетом локальных данных по чувствительности уропатогенов к антибактериальным препаратам [19,20,23,29].

Цель исследования - изучить микробный пейзаж при ИМП и его антибиотикорезистентности у новорожденных детей с АРМП.

\section{Материалы и методы исследования}

Проанализированы результаты микробиологического исследования мочи (172 изолята) у новорожденных детей с ИМП на фоне АРМП, находящихся на лечении в отделениях реанимации и патологии новорожденных в период 2016-2020 гг. Взятие биоматериала проведено по методическим указаниям МУ 4.2.2039-05 «Техника сбора и транспортирования биоматериалов в микробиологические лаборатории». Основные этапы микробиологических исследований выполнены в соответствии с приказом МЗ РФ № 535 «Об унификации микробиологических (бактериологических) методов исследования, применяемых в клинико-диагностических лабораториях лечебно-профилактических учреждений» от 22.04.1985 г. В качестве питательных сред использо- 
Оригінальні дослідження. Урологія та гінекологія

Таблица 2

Устойчивость $(\mathrm{P}+\mathrm{Y} / \mathrm{P})^{*}$ выделенных штаммов Enterobacterales у новорожденных детей с инфекцией мочевых путей на фоне аномалий развития мочевых путей (\%)

\begin{tabular}{|l|l|l|}
\hline Антибактериальные средства & Escherichia coli & Другие представители Enterobacterales \\
\hline Амоксициллин / клавуланат & 28,4 & 31,4 \\
\hline Цефотаксим & 44,6 & 42,8 \\
\hline Цефтазидим & 29,7 & 40,0 \\
\hline Цефепим & 39,2 & 42,8 \\
\hline Цефоперазон / сульбактам & 10,8 & 25,7 \\
\hline Меропенем & 16,2 & 37,1 \\
\hline Амикацин & 14,9 & 17,1 \\
\hline Нитрофурантоин & 14,9 & 42,8 \\
\hline Ципрофлоксацин & 27,0 & 31,4 \\
\hline
\end{tabular}

Примечание: *P+У/P - резистентные и умеренно резистентные штаммы.

ваны 5\% кровяной агар, среда Эндо, желточно-солевой агар, энтерококкагар (производства ФБУН ГНЦ ПМБ г. Оболенск), кандида-агар хромогеник (производитель Conda, Испания). Идентификация микроорганизмов проведена согласно «Определителю бактерий Берджи» 11-го издания классическим рутинным методом, неферментирующих грамотрицательных бактерий (НГОБ) - с помощью набора НЕФЕРМтест 24 microlatest Erba Lachema [26]. Чувствительность к антибактериальным препаратам изучена с помощью диско-диффузионного метода на среде МюллерХинтон 2 производитель Conda, Испания) по клиническим рекомендациям «Определение чувствительности микроорганизмов к антимикробным препаратам» 03) с использованием дисков с антибактериальными препаратами производства Biorad (версия - 2018 США). Мониторинг антибиотикорезистентности выделенных уропатогенов выполнен с помощью компьютерной программы «WHONET 5.6» [28].

Исследование выполнено в соответствии с принципами Хельсинкской декларации. Протокол исследования одобрен Локальным этическим комитетом всех участвующих учреждений. На проведение исследований получено информированное согласие родителей пациентов.

Статистическая обработка результатов проведена с помощью пакета компьютерных программ «Statistica 7». Рассчитана частота встречаемости признака в группах (\%). Определение различий между качественными признаками проведено с использованием критерия $\chi^{2}$. Различия считали статистически значимыми при $\mathrm{p}<0,05$.

\section{Результаты исследования и их обсуждение}

Анализ полученных результатов выявил, что основными возбудителями ИМП у новорожденных детей являются представители порядка Enterobacterales $(63,4 \%)$, что согласуется с литературными данными $[2,3,8,12,30]$.

Из всех энтеробактерий лидирующие позиции занимала Escherichia coli (43\%), при этом 13,5\% выделенных штаммов были продуцентами БЛРС. На втором месте были штаммы Enterobacter spp. (10,5\%), которые продуцировали БЛРС в $16,7 \%$ случаев, Klebsiella pneumoniae выделена в 7\% случаев, продукция БЛРС у них зафиксирована в $8,3 \%$, Citrobacter spp. высевался в 2,4\% случаев, однако уже каждый четвертый штамм был продуцентом БЛРС. Продукция БЛРС, также как и карбапенемаз, представителями порядка Enterobacterales в настоящее время является глобальной проблемой в урологии, затрудняя выбор эффективной антибактериальной терапии $[1,10,18,19]$. Роль грамположительной кокковой флоры (энтерококки, стафилококки) как этиологически значимых факторов развития ИМП в нашем исследовании была чуть выше $(32,9 \%)$ литературных данных (5-25,5\%) [3,4]. Выявленные штаммы Enterococcus spp., относящиеся к условно-патогенной микрофлоре толстой кишки, в этом исследовании встречались в $20 \%$ случаев, эти показатели были выше, чем у детей других возрастных групп [25]. Это, по-видимому, связано не только с увеличением активности данной микрофлоры на фоне функционального иммунодефицита у новорожденных детей, но и с возможным перинатальным инфицированием, и с более широким использованием в стационарных условиях цефалоспоринов, характеризующихся природной неактивностью в отношении данного микроорганизма $[3,14]$. Представители неферментирующих грамотрицательных бактерий (НГОБ), являющиеся одними из основных возбудителей нозокомиальных инфекций, обнаруживались в $6,4 \%$ случаев. Из НГОБ лидирующие позиции занимала 


\section{Оригінальні дослідження. Урологія та гінекологія}

\section{Таблица 3}

Устойчивость $(\mathrm{P}+\mathrm{Y} / \mathrm{P})^{\star}$ выделенных штаммов неферментирующих грамотрицательных бактерий у новорожденных детей с инфекцией мочевых путей на фоне аномалий развития мочевых путей (\%)

\begin{tabular}{|l|l|l|}
\hline Антибактериальные средства & Pseudomonas aeruginosa $(\mathbf{n}=\mathbf{9})$ & Acinetobacter baumannii (n=2) \\
\hline Меропенем & 55,6 & 100 \\
\hline Имипенем & 44,4 & 100 \\
\hline Цефтазидим & 55,6 & - \\
\hline Цефепим & 55,6 & - \\
\hline Цефоперазон / сульбактам & 55,6 & $\mathrm{H} / \mathrm{A}$ \\
\hline Ампициллин / сульбактам & - & $\mathrm{H} / \mathrm{д}$ \\
\hline Амикацин & 44,4 & 50 \\
\hline Ципрофлоксацин & 55,6 & 0 \\
\hline
\end{tabular}

Примечание: *Р+У/Р - резистентные и умеренно резистентные штаммы.

Pseudomonas aeruginosa (5,2\%), на втором месте Acinetobacter baumannii (1,2\%). В настоящее время для представителей НГОБ характерна высокая как природная, так и приобретенная антибиотикорезистентность, связанная в том числе и с продукцией карбапенемаз, что существенно затрудняет выбор рациональной антибактериальной терапии $[1,6,24]$.

Все штаммы представителей порядка Enterobacterales, выделенные у новорожденных детей с ИМП на фоне АРМП, имели высокую устойчивость, создавая определенные трудности в выборе эффективного антибактериального средства (табл. 2).

Наибольшую активность в отношении Escherichia coli проявили цефоперазон / сульбактам (89,2\% чувствительных штаммов), амикацин (85,1\%), меропенем $(83,8 \%)$ и нитрофурантоин $(85,1 \%)$, который, согласно официальной инструкции, не рекомендуется в качестве антимикробного средства при пиелонефрите и не разрешен в периоде новорожденности [22]. Ингибиторзащищенные аминопенициллины и цефалоспорины III генерации, входящие в клинические рекомендации по терапии ИМП у детей [17], были эффективны в отношении кишечной палочки в 71,6\% и 55,4\% соответственно, что согласуется с литературными данными [14]. В отношении других представителей семейства Enterobacterales, выделенных у наших пациентов, пороговый уровень резистентности (20\% изолятов и более), не позволяющий применять противомикробный препарат для терапии инфекционной патологии любой локализации, преодолели амоксициллин / клавуланат, цефотаксим, цефтазидим, цефепим, цефоперазон / сульбактам, меропенем, ципрофлоксацин, нитрофурантоин. Всемирная организация здравоохранения в 2017 г. отнесла некоторых представителей порядка Enterobacterales, в частности Klebsiella spp. и Escherichia coli, a также НГОБ - Acinetobacter baumannii и Pseudomonas aeruginosa - к группе микроорганизмов с критически высокой устойчивостью, представляющих наибольшую угрозу для здоровья человека и требующих создания новых противомикробных средств [27].

Устойчивость выделенных НГОБ (Acinetobacter baumannii и Pseudomonas aeruginosa) представлена в таблице 3 .

Полученные данные о чувствительности основных представителей НГОБ, Pseudomonas aeruginosa u Acinetobacter baumannii, продемонстрировали высокие показатели устойчивости к основным титруемым антибиотикам. В виду небольшого количества выделенных штаммов эти результаты можно рассматривать как недостоверные. Однако при выборе антимикробной терапии при развитии уросепсиса у новорожденного ребенка, особенно при наличии АРМП, требующих хирургической коррекции, необходимо помнить о возможной этиологической роли НГОБ, высоких показателях антибиотикорезистентности данных микроорганизмов и необходимости назначения в большинстве случаев комбинированной терапии [3,6]. Все выделенные штаммы Staphylococcus aureus (2,4\% случаев) характеризовались хорошей чувствительностью к основным титруемым антибиотикам (гентамицин, цефокситин, линкомицин, ванкомицин). Однако коагулазонегативные стафилококки, выявленные уже в 10,5\% случаев и представленные главным образом Staphylococcus saprophyticus и Staphylococcus epidermidis, в 25\% случаев были устойчивы к гентамицину и в 71,4\% случаев - к цефокситину, штаммов, устойчивых к ванкомицину, не выявлено. Выделенные штаммы Enterococcus spp. в каждом 4-м случае были устойчивы к резервному ванкомицину, что выше литературных данных [14,30].

\section{Выводы}

Основными возбудителями ИМП у новорожденных детей с АРМП являются представители порядка Enterobacterales, Enterococcus spp. и НГОБ.

Выделенные штаммы уропатогенов характеризо- 
вались высокой резистентностью, в том числе и к антибиотикам резерва.

Высокие показатели устойчивости выделенной микрофлоры затрудняют выбор эффективной антибиотикотерапии при ИМП на фоне АРМП у новорожденных детей и требуют в большинстве случаев комбинированной антибиотикотерапии с учетом локальных данных антибиотикорезистентности.

Авторы заявляют об отсутствии конфликта интересов.

\section{References/Литература}

1. Beloborodov VB, Gusarov VG, Dekhnich AV et al. (2020). Diagnostics and antimicrobial therapy of the infections caused by multiresistant microorganisms. Guidelines of the Association of Anesthesiologists-Intensivists, the Interregional Non-Governmental Organization Alliance of Clinical Chemotherapists and Microbiologists, the Interregional Association for Clinical Microbiology and Antimicrobial Chemotherapy (IACMAC), and NGO Russian Sepsis Forum. Messenger of Anesthesiology and Resuscitation. 17 (1): 52-83. [Белобородов ВБ, Гусаров ВГ, Дехнич АВ и др. (2020). Диагностика и антимикробная терапия инфекций, вызванных полирезистентными микроорганизмами. Методические рекомендации Российской некоммерческой общественной организации «Ассоциация анестезиологов-реаниматологов», Межрегиональной общественной организации «Альянс клинических химиотерапевтов и микробиологов», Межрегиональной ассоциации по клинической микробиологии и антимикробной химиотерапии (МАКМАХ), общественной организации «Российский Сепсис Форум». Вестник анестезиологии и реаниматологии. 17 (1): 52-83]. doi: 10.21292/2078-5658-2020-17-1-52-83.

2. Bilgili G, Yuksel MB. (2015). Urinary tract infections in newborns. Medical Science and Discovery. 2 (1): 124. doi: 10.17546/ msd.71668.

3. Chugunova OL, Dumova SV. (2010). Features of diseases of the urinary system in young children. Pharmacotherapy of Childhood Diseases: A Guide. Moscow: Medical Information Agency: 704-734. [Чугунова ОЛ, Думова СВ. (2010). Особенности заболеваний органов мочевой системы у детей раннего возраста. Фармакотерапия детских болезней: Руководство. Москва: Медицинское информационное агентство: $704-$ 734].

4. Chugunova OL, Shumikhina MV, Dumova SV. (2013). Current overview of the urinary system infection in newborns and infants. Pediatria. 4 (42): 38-47. [Чугунова ОЛ, Шумихина МВ, Думова СВ. (2013). Современные представления об инфекции органов мочевой системы у новорожденных и детей раннего возраста. Педиатрия. 4 (42): 38-47].

5. Dakic D, Dragas LJ, Rudanovic R. (2014). Urinary Tract Infections In Newborns. Archives of Disease in Childhood. 99: A422. doi: 10.1136/archdischild-2014-307384.1173.

6. Edelstein MV, Sukhorukova MV, Skleenova EYu, Ivanchik NV, Mikotina AV, Shek EA, Dekhnich AV, Kozlov RS, «MARATHON» study group. (2017). The antibiotic resistance of nosocomial strains of Pseudomonas aeruginosa in Russian hospitals: the results of multicenter epidemiological study MARAFON 2013-2014. Clinical microbiology and antimicrobial chemotherapy. 19 (1): 37-41. [Эйдельштейн MB, Сухорукова МВ, Склеенова ЕЮ, Иванчик НВ, Микотина АВ, Шек ЕА, Дехнич $\mathrm{AB}$, Азизов ИС, Козлов РС, исследовательская группа «МАРАФОН». (2017). Антибиотикорезистентность нозоко- миальных штаммов Pseudomonas aeruginosa в стационарах России: результаты многоцентрового эпидемиологического исследования «МАРАФОН» 2013-2014. Клиническая микробиология и антимикробная химиотерапия. 19 (1): 37-41].

7. Ergon EY, Acar BH, Çelik Kıymet, Çolak Rüya et al. (2017). Urinary Tract Infections in Neonates. Turkish Journal of Pediatric Disease: 1-5. doi: 10.12956/tjpd.2017.288.

8. Gladin DP, Lifanova MV, Lebedeva ND. (2019). The urinary microbiota and severity of infection in children with surgical pathology. Forcipe. 2 (3): 3-13. [Гладин ДП, Лифанова МВ, Лебедева НД. (2019). Микрофлора мочи и тяжесть инфекции у детей с хирургической патологией. Forcipe. 2 (3): 3-13]

9. Kushnareva MV, Dementyeva GM, Shabelnikova EI et al. (2020). Urinary tract infection in premature newborns. Pediatrician practice. 4: 28-32. [Кушнарева МВ, Дементьева ГМ, Шабельникова ЕИ и др. (2020). Инфекция мочевыводящих путей у недоношенных новорожденных. Практика педиатра. 4: 28-32].

10. Letifov GM, Kaplieva OV, Burova IJa et al. (2012). The variability of antibioticosensibility of uropatthologens for pyelonephritis in children. Meditsinskij vestnik YUga Rossii: 50. [Летифов ГМ, Каплиева ОВ, Бурова ИЯ и др. (2012). Изменчивость этиологической структуры и антибиотикочувствительность уропатологической флоры при пиелонефрите у детей. Медицинский вестник Юга России. Приложение: 50].

11. Lopatkin NA. (2013). Anomalii razvitiya pochek, mochevyih putey i muzhskih polovyih organov. V kn: Urologiya, Moskva «Meditsina»: 147-210. [Лопаткин НА. (2013). Аномалии развития почек, мочевых путей и мужских половых органов. В кн: Урология, Москва «Медицина»: 147-210.

12. Malkoch AB, Filatova NN, Dudko MYu et al. (2019). Urinary tract infection in children. Pharmateca. 26 (1): 38-43. [Малкоч АВ, Филатова НН, Дудко МЮ и др. (2019). Инфекция мочевых путей у детей. Фарматека. 26 (1): 38-43]. URL: https://dx.doi.org/10.18565/pharmateca.2019.1.38-43.

13. Melnikova EA, Luchaninova VN, Krukovich EV et al. (2017). Difficulties and opportunities for diagnosis of urinary tract infection in newborns. Pediatria. 96 (56): 8-14. [Мельникова ЕА, Лучанинова ВН, Крукович ЕВ и др. (2017). Трудности и возможности диагностики инфекции мочевой системы у новорожденных. Педиатрия. 96 (56): 8-14].

14. Melnikova EA, Luchaninova VN, Zaytseva EA et al. (2015). The structure and antibiotic resistance of uropatogens of discharges from infants with urinary tract infection. Practical medicine. 2 (87): 97-100. [Мельникова ЕА, Лучанинова ВН, Зайцева ЕА и др. (2015). Структура и антибиотикорезистентность уропатогенов, выделенных у новорожденных с инфекцией мочевых путей. Практическая медицина. 2 (87): 97-100].

15. Melnikova EA, Zaitseva EA, Luchaninova VN et al. (2019). Differentiated approaches to management of urinary tract infections in children taking into account enterococcus faecalis etiology. Pacific Medical Journal. 4 (78): 60-65. [Мельникова ЕA, Зайцева ЕА, Лучанинова ВН и др. (2019). Дифференцированные подходы к лечению инфекции мочевой системы у детей с учетом этиологического фактора Enterococcus faecalis. Тихоокеанский медицинский журнал. 4 (78): 60-65].

16. Menovshchikova LB, Rudina Yu, Garmanova TN et al. (2015). Clinical guidelines for pediatric urology-andrology. M: Publishing house «Pero»: 240. [Меновщиковой ЛБ, Рудина ЮЭ, Гармановой ТН и др. (2015). Клинические рекомендации по детской урологии-андрологии. М: Издательство «еро»:240].

17. Ministry of Health of the Russian Federation. (2018). Urinary tract infections. Clinical guidelines: 24. [Министерство здравоохранения Российской Федерации. (2018). Инфекции мочевыводящих путей. Клинические рекомендации: 24].

18. Palagin IS, Sukhorukova MV, Dekhnich AV et al. (2019). Anti- 


\section{Оригінальні дослідження. Урологія та гінекологія}

microbial resistance of pathogens causing community-acquired urinary tract infections in russia: results of multicenter study «DARMIS-2018». Clinical microbiology and antimicrobial chemotherapy. 21 (2): 134-146. [Палагин ИС, Сухорукова МВ, Дехнич АВ, Эйдельштейн МВ, Перепанова ТС, Козлов РС, исследовательская группа «ДАРМИС-2018». (2019). Антибиотикорезистентность возбудителей внебольничных инфекций мочевых путей в России: результаты многоцентрового исследования «ДАРМИС-2018». Клиническая микробиология и антимикробная химиотерапия. 21 (2): 134-146]. doi: 10.36488/cmac.2019.2.134-146.

19. Perepanova TS, Kozlov RS, Rudnov VA et al. (2020). Antimicrobial therapy and prevention of infections of the kidneys, urinary tract and male genital organs. Federal clinical guidelines. Moscow: 72. [Перепанова ТС, Козлов РС, Руднов ВА и др. (2020). Антимикробная терапия и профилактика инфекций почек, мочевыводящих путей и мужских половых органов. Федеральные клинические рекомендации. М: 72].

20. Pickard R, Bartoletti R, Bjerklund-Johansen TE et al. (2016). EAU Guidelines on urological infections. European Association of Urology: 16.

21. Renkema KJ, Winpred PJ, Scovorodkin IN et al. (2011). Nonel Perspectives for undestending congenital anomalies of the kidney and urinary tract (CAKUT). Nephrol Dial Transplant Dec. 26 (14): 3841-3851. doi: 10.1093/ndt/gfr655.

22. SRM. (2021). State Register of Medicines. [ГРЛП. (2021). Государственный реестр лекарственных препаратов]. URL: http://www.grls.rosminzdrav.ru.

23. Stein R, Dogan HS, Hoebeke P et al. (2015). Urinary tract infections in children: EAU/ESPU guidelines. Eur Urol. 67 (3): 546558. doi: 10.1016/j.eururo.2014.11.007.1.

24. Sukhorukova MV, Edelstein MV, Skleenova EYu, Ivanchik NV, Shek EA, Dekhnich AV, Kozlov RS, «MARATHON» study group. (2017). Antimicrobial resistance of nosocomial Acinetobacter spp. isolates in Russia: results of multicenter epidemiological study «MARATHON» 2013-2014. Clinical microbiology and antimicrobial chemotherapy. 19 (1): 42-48. [Сухорукова MB,
Эйдельштейн МВ, Склеенова ЕЮ, Иванчик НВ, Шек ЕА, Дехнич АВ, Козлов РС, исследовательская группа «МАРАФОН». (2017). Антибиотикорезистентность нозокомиальных штаммов Acinetobacter spp. в стационарах России: peзультаты многоцентрового эпидемиологического исследования «МАРАФОН» 2013-2014. Клиническая микробиология и антимикробная химиотерапия. 19 (1): 42-48].

25. Veshkurtseva IM, Akselrov MA, Yamshchikova EV et al. (2020). Etiological structure and antibiotic resistance of urinary infections pathogens in children. Pediatria n.a. G.N. Speransky. 99 (5): 27-32. [Вешкурцева ИМ, Аксельров МА, Ямщикова ЕВ и др. (2020). Этиологическая структура и антибиотикорезистентность возбудителей инфекций мочевых путей у детей. Педиатрия. 99 (5): 27-32]. doi: 10.24110/0031-403X-2020-99-5-27-32.

26. Vos P, Garrity G, Jones D et al. (2009). Bergeys manual of systematic bacteriology. New York: Springer-Verlag. 3: 1450.

27. VOZ. (2021). VOZ publikuet spisok bakteriy, dlya borbyi s kotoryimi srochno trebuetsya sozdanie novyih antibiotikov. [BO3. (2021). ВОЗ публикует список бактерий, для борьбы с которыми срочно требуется создание новых антибиотиков]. URL: http://www.who.int/mediacentre/news/releases/2017/ bacteria-antibiotics-needed/ru/.

28. WHO. (2021). World Health Organization. URL: http://www.who.int.

29. Zakharova IN, Machneva EB, Memladze EB et al. (2017). Diagnosis and treatment of urinary tract infections in children: whats new? Medical advice. 1: 180-185. [Захарова ИН, Мачнева ЕБ, Мумладзе ЭБ и др. (2017). Диагностика и лечение инфекций мочевых путей у детей: что нового? Медицинский совет. 1 : 180-185]. doi. 10.21518/2079-701x-2017-1-180-185.

30. Zhdanova OA, Gurovich OV, Akhmatova SN et al. (2017). Microflora of urine in urinary tract infections in children of different ages, Applied information aspects of medicine. 20 (3): 89-93. [Жданова ОА, Гурович ОВ, Ахматова СН и др. (2017). Микрофлора мочи при инфекции мочевых путей у детей разного возраста, Прикладные информационные аспекты медицины. 20 (3): 89-93].

\section{Відомості про авторівх:}

Вешкуриева Ізабелла Михайлівна - к.мед.н., дои. каф. госпітальної терапії з курсами ендокринології та клінічної фармакології ФДБОУ ВО Тюменський ДМУ МОЗ Росії, лікар-клінічний бармаколог ДБУЗ ТО «ОКЛ №2».е-mail: vizabella-64@mail.ru. https://orcid.org/0000-0003-0215-7709.

Аксельров Михайло Олександрович - д.мед.н., дои., зав. каб. дитячої хірургї̈ ФГБОУ ВО Тюменський ДМУ МОЗ Росії, зав. дитячим хірургічним відділенням №1 ДБУЗ ТО «ОКЛ №2». e-mail: akselerov@mail.ru; тел. +7(345) 228-70-95. https://orcid.org/0000-0001-6814-8894.

Ємелянова Вікторія Олександрівна - асистент каф. дитячої хірургії ФГБОУ ВО Тюменський ДМУ МОЗ Росії, керівник служби надання медичноі допомоги дітям ДБУЗ ТО «ОКЛ №2».e-mail: oria@yandex.ru; https://orcid.org/0000-0002-9857-9174.

Супрунець Світлана Миколаївна - к.мед.н., дои. каф. дитячих хвороб педіатричного факультету ФГБОУ ВО Тюменський ДМУ МОЗ Росії, зав. ОАРИТН ДБУЗ ТО «ОКЛ №2». e-mail: suprunets.s@gmail.com; https://orcid.org/0000-0001-85791857.

Столяр Олександр Володимирович - асистент каб. дитячої хірургії ФГБОУ ВО Тюменський ДМУ МОЗ Росіï. e-mail: stolyar.al@yandex.ru; https://orcid. org/0000-0002-0704-5418.

Гордійчук Світлана Миколаївна - к.мед.н., асистент каф. дитячих хвороб педіатричного факультету ФГБОУ ВО Тюменський ДМУ МОЗ Росії. e-mail: svgordiychuk@mail.ru; https://orcid.org/0000-0001-65128329.

Лебедєва Клавдія Олексіївна - к.мед.н., дои. каф. дитячих хвороб педіатричного факультету ФГБОУ ВО Тюменський ДМУ МОЗ Росії. е-таі:: lebedeva. klavdia@gmail.com; https://orcid.org/0000-0002-1422-5863.

Ашихміна Олена Петрівна - к.мед.н., дои. каф. дитячих хвороб педіатричного факультету ФГБОУ ВО Тюменський ДМУ МОЗ Росії. e-mail: kla-chap113@narod.ru; https://orcid.org/ https://orcid.org/0000-0002-0537-5667.

Баринов Олександр Леонідович - зав. лабораторією клінічної мікробіологіï «ОКД № 2». e-mail: okb2_barinov@mail.ru; https://orcid.org/0000-0002-1552-1226. 


\title{
А.Р. Поцюрко ${ }^{1}$, І.Я. Гримак ${ }^{1}$, Н.В. Гельнер ${ }^{3}$, Б.І. Гижа ${ }^{1}$, Д.З. Іваськевич ${ }^{1}$, Е.Ф. Чайківська ${ }^{1,2}$, Л.Ю. Гижа ${ }^{1,2}$, Р.В. Стеник ${ }^{1}$, А.О. Дворакевич ${ }^{1}$, Р.А. Поцюрко ${ }^{1}$, 3.І. Глушко \\ Особливості фемінізуючої хірургічної корекції в дітей з розладами статевого розвитку
}

\author{
${ }^{1}$ КНП ЛОР «Львівська обласна дитяча клінічна лікарня «ОХМАТДИТ», Україна \\ 2Львівський національний медичний університет імені Данила Галицького, Украйна \\ ${ }^{3}$ ДУ «Інститут спадкової патології НАМН України», м. Львів

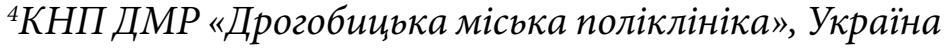

Paediatric surgery.Ukraine.2021.3(72):63-68; doi 10.15574/PS.2021.72.63

For citation: Potsiurko AR, Hrymak IYa, Helner NV, Hyzha Bl et al. (2021). Peculiarities of feminizing surgical correction in children with disorders of sexual development. Paediatric Surgery.Ukraine. 3(72):63-68; doi 10.15574/PS.2021.72.63.

Мета - проаналізувати власні результати хірургічного лікування тяжких форм розладів статевого розвитку (РСР) у дітей після операцій фемінізуючого типу; визначити практичні протокольні показання з вибору напряму хірургічної корекції.

Матеріали та методи. Упродовж останніх 5 років до урологів Львівської обласної дитячої клінічної лікарні «ОХМАТДИТ» по медичну допомогу звернулися батьки 12 дітей з РСР, ознаками гермафродитизму (двостатевості). Після комплексного обстеження діагностовано: адреногенітальний синдром у 5 дівчаток, яких скеровано для подальшого лікування до дитячих медичних центрів м. Києва; справжній гермафродитизм - в 1 дитини; синдром змішаної дисгенезії гонад (СЗДГ) - у 3 дітей; жіночий псевдогермафродитизм (без встановлення генезу) - в 1 дитини; неповну форму тестикулярної фемінізації, синдром Морріса (чоловічий псевдогермафродитизм) - у 2 дітей.

У зв'язку з вираженою маскулінізацією зовнішніх геніталій 2 дітям із СЗДГ та 1 дівчинці з псевдогермафродитизмом виконано хірургічну корекцію фемінізуючого типу, зокрема, реконструкцію генітальної зони, мобілізацію та резекцію стінок урогенітального синусу, резекцію печеристих тіл статевого органа (дітям з СЗДГ) з формуванням і транслокацією клітора, вульвопластику з лабіопластикою малих і великих статевих губ, кольпопластику. Діти з синдромом Морріса готуються до корекції за «жіночим» типом.

Результати. Кожна дитина мала персональний план обстеження. Верифікація стану дитини тривала від декількох тижнів до 2-3 міс. У дітей, яким провели фемінізуючі операції, не було чоловічих структур і виявлялися відносно добре розвинуті жіночі. Виконувалася більш «природна», менш травматична корекція для кожного конкретного випадку. В усіх прооперованих дітей піхва відкривалася в урогенітальний синус дистальніше зовнішнього сфінктера уретри, тому виконувати пластику передньої стінки піхви не було потреби (формувалися задня та бокові стінки). 3 усіх дітей, які перебували на лікуванні в зазначеній клініці, у двох останніх стать юридично переоформлена на протилежну.

Висновки. Народження дитини з тяжкою формою РСР є надзвичайно серйозною проблемою для батьків, медиків, психологів і соціальних працівників. Порушення статевої диференціації дитини потребує розширеного комплексного обстеження. Діти з тяжкими формами гіпоспадії підлягають обов'язковому генетичному обстеженню. Дані статистики та власний досвід вказують на вищу частоту хірургічної корекції за «жіночим» типом у таких випадках. Під час корекції фемінізуючого типу найскладнішим етапом у технічному розумінні є резекція печеристих тіл статевого органа з кліторопластикою і транслокацією клітора, а найвідповідальнішим етапом у функціональному відношенні є кольпопластика.

Хірургічне втручання не є завершальним етапом лікування таких пацієнтів. Діти з інтерсексуальними станами в подальшому потребують постійного динамічного спостереження лікарів гінекологів, урологів, онкологів, ендокринологів, психологів з відповідною корекцією терапії. 
Дослідження виконано відповідно до принципів Гельсінської декларації. Протокол дослідження ухвалено Локальним етичним комітетом усіх зазначених у роботі установ. На проведення досліджень отримано інформовану згоду батьків, дітей.

Автори заявляють про відсутність конфлікту інтересів.

Ключові слова: розлади статевого розвитку, гермафродитизм, фемінізуюча корекція.

\section{Peculiarities of feminizing surgical correction in children with disorders of sexual development A.R. Potsiurko', I.Ya.Hrymak', N.V. Helner', B.I. Hyzha', D.Z. Ivaskevych', E.F. Chaikivska ${ }^{1,2}$, L.Yu.Hyzha' ${ }^{1,2}$, R.V. Stenyk', A.O. Dvorakevych', R.A. Potsiurko', Z.I. Hlushko ${ }^{4}$}

${ }^{1}$ Lviv Regional Children's Clinical Hospital "OHMATDYT», Ukraine

${ }^{2}$ Danylo Halytskyi Lviv National Medical University, Ukraine

IInstitute of Hereditary Pathology of NAMS of Ukraine, Lviv

${ }^{4}$ Drohobych City Polyclinic, Ukraine

Purpose - to analyze own results of surgical treatment of serious forms of disorders of sexual development (DSD) in children after feminizing surgeries. To define practical protocol guides on the choice of the type of surgical correction.

Materials and methods. Over the past 5 years surgeons of Lviv regional paediatric clinical hospital «OHMATDYT» have examined 12 children with DSD, signs of hermaphroditism (intersex). After complex examination the following states were diagnosed: androgenital syndrome in 5 girls (referred for further treatment to Kyiv paediatric medical centres); true hermaphroditism - 1 child; mixed gonadal dysgenesis (MCG) - 3 children; female pseudohermaphroditism (without determining genesis) - 1 child; partial testicular feminization syndrome, Morris syndrome (male pseudohermaphroditism) - 2 children.

In connection with marked masculinization of external genitalia two children with MCG and the girl with pseudohermaphroditism underwent feminizing surgery, namely genital zone reconstruction, mobilization and excision of urogenital sinus walls, excision of genital cavernous bodies (in children with MCG) with clitoroplasty, vulvoplasty with labioplasty and vaginoplasty. Children with Morris syndrome are being prepared to feminizing surgery.

Results. Each child had a personal examination plan. Verification of a child's state lasted from several weeks to 2-3 months. Children who underwent feminizing surgery did not have male structures and had relatively well-developed female structures. More «natural», less traumatizing correction was preformed for each specific case. In all children who underwent surgery vagina opened into urogenital sinus lower than external urethral sphincter, so there was no need to form front vagina wall (back and side walls were formed). Out of all children treated in our hospital gender was legally changed to the opposite.

Conclusions. The birth of a child with DSD is a most challenging problem for parents, doctors, psychologists and social workers. Such states require complex examination. Children with severe hypospadias must undergo genetic examination. Statistic data and our own experience show higher frequency of feminizing surgeries in such cases. The most difficult part of such surgeries proves to be the excision of genital cavernous bodies with clitoroplasty and clitoris translocation; the most responsible part in functional sense is vaginoplasty. Surgical treatment is not the final stage of treatment for such patients. Children with DSD require constant further dynamic checkups by gynaecologists, urologists, oncologists, endocrinologists, psychologists with relevant therapy correction.

The research was carried out in accordance with the principles of the Helsinki declaration. The study protocol was approved by the Local ethics committee of all participating institution. The informed consent of the patient was obtained for conducting the studies.

No conflict of interest was declared by the authors.

Key words: disorders of sexual development (DSD), hermaphroditism, feminizing correction

Особенности феминизирующей хирургической коррекции у детей с расстройствами полового развития А.Р. Почюрко ${ }^{1}$ И.Я. Гримак ${ }^{1}$, Н.В. Гельнер ${ }^{3}$, Б.И. Гижа ${ }^{1}$, Д.З. Іваськевич ${ }^{1}$, Е.Ф. Чайківська ${ }^{1,2}$, Л.Ю. Гижа Р.В. Стеник ${ }^{1}$, А.О. Дворакевич ${ }^{1}$ Р.А. Почюрко ${ }^{1}$, 3.І. Глушко

${ }^{1}$ КНПЛОС «Львовская областная детская клиническая больница «ОХМАТДЕТ», Украина

${ }^{2}$ Львовский национальный медицинский университет имени Данила Галицкого, Украина

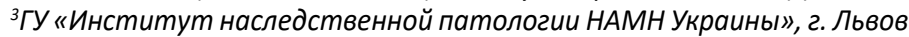

${ }^{4}$ КНП ДМР «Дрогобицкая городская поликлиника», Украина

Цель - проанализировать собственные результаты хирургического лечения тяжелых форм нарушения полового развития (НПР) у детей после операций феминизирующего типа; установить практические протокольные показания к выбору направления хирургической коррекции.

Материалы и методы. На протяжении последних 5 лет к урологам Львовской областной детской клинической больницы «Охматдет» за медицинской помощью обратились родители 12 детей с НПР, признаками гермафродитизма (двуполости). После комплексного обследования диагностированы: андрогенитальный синдром - у 5 девочек, направленных для дальнейшего лечения в детские медицинские центры Киева; истинный гермафродитизм - в 1 ребенка; синдром смешанной дисгенезии гонад (ССдГ) - у 3 детей; женский псевдогермафродитизм (без установления генезиса) - у 1 ребенка; неполная форма тестикулярной феминизации, синдром Морриса (мужской псевдогермафродитизм) у 2 детей. В связи с выраженной маскулинизацией внешних гениталий 2 детям с ССДГ и 1 девочке с псевдогермафродитизмом выполнена хирургическая коррекция феминизирующего типа, а именно, реконструкция генитальной зоны, мобилизация и резекция стенок урогенитального синуса, резекция пещеристых тел полового органа (детям с ССДГ) с формированием и транслокацией клитора, вульвопластика с лабиопластикой малых и больших половых губ, кольпопластика. Дети с синдромом Морриса готовятся к коррекции по женскому типу.

Результаты. У каждого ребенка был персональный план обследования. Верификация состояния ребенка длилась от нескольких недель до 2-3 месяцев. У детей, которым проводились феминизирующие операции, отсутствовали мужские структуры и имелись в наличии достаточно хорошо развитые женские. Проводилась более «естественная», менее травматическая коррекция для каждого конкретного случая. У всех прооперированных детей влагалище открывалось в урогенитальный синус дистальнее внешнего сфинктера уретры, поэтому не было необходимости проводить пластику передней стенки влагалища (формировались задняя и боковая стенки). Из всех детей, находившихся на лечении в вышеуказанной клинике, у двух последних пол юридически переоформлен на противоположный. 
Выводы. Рождение ребенка с тяжелой формой НПР является чрезвычайно серьезной проблемой для родителей, медиков, психологов и социальных работников. Нарушение половой дифференциации ребенка требует расширенного комплексного обследования. Дети с тяжелыми формами гипоспадии подлежат обязательному генетическому обследованию. Данные статистики и собственный опыт указывают на более высокую частоту хирургической коррекции по «женскому» типу в таких случаях. При коррекции феминизирующего типа наиболее тяжелым этапом в техническом отношении является резекция пещеристых тел полового органа с клиторопластикой и транслокацией клитора, самым ответственным этапом в функциональном отношении является кольпопластика. Хирургическое лечение не является завершающим этапом лечения таких пациентов. Дети с интерсексуальными состояниями в дальнейшем требуют постоянного динамического наблюдения врачей гинекологов, урологов, онкологов, эндокринологов, психологов с соответствующей коррекцией терапии.

Исследование выполнено в соответствии с принципами Хельсинкской декларации. Протокол исследования одобрен Локальным этическим комитетом всех участвующих учреждений. На проведение исследований получено информированное согласие родителей, детей.

Авторы заявляют об отсутствии конфликта интересов.

Ключевые слова: нарушения полового развития, гермафродитизм, феминизирующая коррекция.

Важливим сегментом роботи дитячого уролога $€$ діагностика та лікування захворювань репродуктивної системи в дітей. Сім’я, у якій народилася дитина 3 будь-якими формами пошкодження статевих органів (розладами статевого розвитку - РСР), часто зазнає психологічних і моральних страждань, зокрема, у разі тяжких форм порушення статевої диференціації, коли визначення статі новонародженої дитини стає проблемним. Батьки часто драматизують власну оцінку ознак двостатевості їхньої дитини. Інтерсексуальні стани стають значною проблемою і для медиків. Незважаючи на значний прогрес у вивченні фізіології та молекулярної біології формування статевої системи в дітей, починаючи з періоду ембріогенезу, ендокринологічна та хірургічна верифікація і лікування таких розладів часто відстають. Перед великою групою медичних і соціальних працівників, які допомагають хворим дітям, виникає великий пласт медичних, психологічних і соціальних проблем [5].

Хоча й спостерігається стрімкий розвиток медичної науки, діагностика та корекція тяжких форм порушення статевої диференціації залишається однією 3 найскладніших проблем і становить серйозний виклик для дитячих лікарів.

Стать як цілісне поняття включає три основні елементи:

1) генетична стать клітин (XX i XY);

2) гонадна стать (наявність яєчок чи яєчників);

3) соматична стать (будова зовнішніх статевих органів і внутрішніх статевих шляхів).

Інтерсексуальні стани, або гермафродитизм - це дисгармонія між цими елементами, тобто коли фенотип чітко не відповідає каріотипу [5].

3 розвитком медичної науки 4 основні групи інтерсексуальних станів (справжній гермафродитизм, жіночий псевдогермафродитизм, чоловічий псевдогермафродитизм, синдром змішаної дисгенезії гонад) доповнюються новою інформацією і більш уточненими формами РСР. Однак навіть після комплексного розширеного обстеження, можливого в сучасних умовах вітчизняної медицини, інколи до- сить складно віднести конкретний випадок до тієї чи іншої групи $[3,5]$.

Це означає, що підхід до вирішення проблем таких дітей має бути максимально виваженим, із залученням широкого спектра спеціалістів, які займаються питаннями статі та іїі корекції, з погодженням побажання батьків і вирішенням усіх соціальних та психологічних аспектів, адже визначається доля дитини на все життя.

«Золотим» правилом лікування хлопчиків із тяжкими формами гіпоспадії в Львівській обласній дитячій клінічній лікарні «ОХМАТДИТ» $є$ комплексне генетичне обстеження дитини до операції для запобігання можливій лікарській помилці. Зміна принципових підходів до хірургічної корекції гіпоспадії, що спостерігається протягом останніх років у вітчизняній дитячій урології, вибір раціонального методу уретропластики, уміння підготувати пластичний матеріал до операції, можливість застосування високоякісного шовного матеріалу, а також зростання технічної майстерності дитячих урологів з урахуванням високого командного професіоналізму всього хірургічного колективу, адекватне анестезіологічне забезпечення операції та післяопераційного періоду дали змогу лікарям клініки значно поліпшити результати лікування, зменшити частоту післяопераційних ускладнень і, відповідно, підвищити якість життя маленьких пацієнтів.

Однак звернення пацієнтів з інтерсексуальними станами до клініки стимулювало урологів лікарні до вивчення та впровадження також і фемінізуючих типів хірургічної корекції статевих вад розвитку.

Мета дослідження - проаналізувати власні результати хірургічного лікування тяжких форм РСР у дітей після операцій фемінізуючого типу, визначити практичні протокольні показання з вибору напряму хірургічної корекції.

\section{Матеріали та методи дослідження}

Упродовж останніх 5 років до урологів Львівської обласної дитячої клінічної лікарні «ОХМАТДИТ» по 
медичну допомогу звернулися батьки 12 дітей з тяжкими РСР, ознаками гермафродитизму (двостатевості). Частина цих дітей протягом тривалого часу перебувала на обстеженні в різних дитячих лікарнях України, однак, на жаль, без вирішення проблем.

Так, 5 пацієнтів після обстеження виявилися дівчатками з адреногенітальним синдромом і були скеровані для консервативної терапії ендокринних порушень та подальшої хірургічної корекції до дитячих медичних центрів м. Києва [4].

У 16-річної дитини, фенотипічно дівчини, батьки якої звернулися до дитячого гінеколога у зв'язку з відсутністю місячних, генетичне обстеження виявило каріотип 46 XY. Зовнішні статеві органи та вторинні статеві ознаки сформовані правильно. Під час лапароскопії виявлено помірно гіпоплазовані матку і маткові труби, а також дві дисгенетичні гонади. Зроблено біопсію. За результатами гістологічного дослідження виявлено елементи яєчника з ознаками гонадобластоми з обох біоптатів. Проведено лапароскопічну гонадектопію. Дитина перебувала під динамічним спостереженням дитячого онколога та гінеколога [6].

14-річна дитина, що виховувалася з народження як дівчинка, декілька років перебувала під спостереженням дитячого хірурга за місцем проживання 3 діагнозом двобічної пахової кили. Батьки від операції відмовилися і повторно звернулися до дитячих лікарів у зв'язку з відсутністю місячних у 13-річному віці. Під час огляду виявлено ознаки двостатевості: гіпертрофію клітора, короткий урогенітальний синус (УГС) з вузьким входом у піхву, недорозвинуті статеві губи. Слабко розвинені молочні залози. У пахових ділянках пальпуються добре розвинуті яєчкоподібні структури. За результатами ультразвукового дослідження (УЗД) не виявлено матки, маткових труб і яєчників, що підтверджено за допомогою комп'ютерної томографії (КТ) та лапароскопії. За даними ендогенітоскопії: піхва вкорочена, закінчується сліпо. Рівень вільного тестостерону в крові підвищений. Каріотип - 46 ХY. Дитині встановлено діагноз «Неповна форма тестикулярної фемінізації, синдром Морріса (чоловічий псевдогермафродитизм)». Заплановано оперативне лікування - двобічну гонадектомію з генітальною реконструкцією за «жіночим» типом $[2,8]$.

Подібні зміни виявлено у 17-річної дитини. Відмінність полягала у виявленому під час лапароскопії двобічному абдомінальному крипторхізмі з ознаками атрофії яєчок та низьким рівнем вільного тестостерону в крові. Дитина із синдромом Moppica також готується до хірургічної корекції.
Батьки 1-річного хлопчика звернулися по медичну допомогу з діагнозом «Гіпоспадія II ст., правобічний крипторхізм». Ліве яєчко пальпується в калитці, без ознак патології. Під час ревізії правого пахового каналу в дитини виявлено елементи жіночої статевої системи: маткову трубу та яєчник, що підтверджено гістологічно (останні вправлено в черево). Генетичне обстеження: каріотип - 46 XY. Під час лапароскопії матки не виявлено. Знайдено рудиментарну маткову трубу з яєчником, які були видалені. Випадок можна класифікувати як справжній гермафродитизм. Заплановано хірургічну корекцію гіпоспадії.

11 -річна дитина з тяжкою формою порушення статевої диференціації при зовнішньому огляді та вторинними статевими ознаками за «жіночим» типом. Яєчка не пальпуються. Каріотип - 46 ХХ. Адреногенітальний синдром заперечено ендокринологічними методами обстеження. За результатами лапароскопії: внутрішні геніталії жіночі, без патологічних відхилень. Під час магнітно-резонансної томографії (МРТ) виявлено добре розвинуту піхву та довгий УГС. За даними ендогенітоскопії, в ампулу УГС відкривається вічко уретри та вхідний отвір піхви. Проведено хірургічну корекцію: реконструкцію генітальної зони, мобілізацію та резекцію стінок УГС, транслокацію клітора (без його резекції), вульвопластику з лабіопластикою малих і великих статевих губ, кольпопластику. Тривалість операції - 8 год (включно з ендоскопічним обстеженням). Післяопераційний період - без ускладнень. Випадок класифіковано як жіночий несправжній гермафродитизм без встановлення генезу захворювання, враховуючи відсутність анамнезу життя дитини. Дівчинка 3 асоціальної сім'ї. За 1 місяць після операції в дівчинки проявилося менархе без особливостей [1,7].

Ще 2 дітей звернулися до лікарні з діагнозом «Гіпоспадія IV-V ст.» у віці 1,5 і 2 роки відповідно. При огляді дітей яєчка не пальпувалися ні в лабіоскротальних складках, ні в пахових ділянках. Під час генетичного обстеження виявлено в першої дитини каріотип 46 XY, у другої - 47 XXY. Ми об’єднали їх в одну групу, враховуючи подібність виявлених змін та однотипність проведених операцій. Під час УЗД в обох пацієнтів знайдено мюллерові протоки. При лапароскопії виявлено гіпоплазовану матку, маткову трубу і яєчник без видимих анатомічних змін 3 одного боку та дисгенетичну гіпоплазовану гонаду з іншого. Проведено гонадектомію останньої та біопсію яєчника. За даними гістологічного дослідження виявлено елементи яєчка видаленої гонади. Під час 
ендоскопії знайдено відносно короткий УГС, в який відкривається вічко уретри та вхідний отвір піхви. Остання добре розвинута, візуалізується шийка матки. Особливістю обох дітей був добре розвинутий статевий орган з вираженою девіацією у вентральний бік (тому встановлено діагноз гіпоспадії). В обох випадках консиліумом лікарів рекомендовано хірургічну корекцію вад за «жіночим» типом. Ці рекомендації співпали з побажанням батьків. Проведено хірургічну корекцію: реконструкцію генітальної зони, мобілізацію та резекцію стінок УГС, резекцію печеристих тіл статевого органа з формуванням і транслокацією клітора, вульвопластику 3 лабіопластикою малих і великих статевих губ, кольпопластику. Тривалість операцій - відповідно 5 год і 6 год (включно з ендоскопічним обстеженням). Післяопераційний період - без ускладнень. Випадки класифіковано як синдром змішаної дисгенезії гонад. Діти перебувають під динамічним спостереженням дитячих уролога, гінеколога та ендокринолога. На цьому етапі основне проблемне питання - «поведінка» залишеного яєчника $[1,7]$.

У всіх прооперованих дітей піхва відкривалася в УГС дистальніше зовнішнього сфінктера уретри, тому не було потреби виконувати пластику передньої стінки піхви (формувалися задня та бокові стінки).

3 усіх дітей, що перебували на лікуванні в зазначеній клініці, у двох останніх стать юридично переоформлена на протилежну.

Дослідження виконано відповідно до принципів Гельсінської декларації. Протокол дослідження ухвалено Локальним етичним комітетом зазначеної в роботі установи. На проведення досліджень отримано інформовану згоду батьків, дітей.

\section{Результати дослідження та їх обговорення}

Усі діти з РСР потребували значного обсягу діагностичної і лікувальної роботи, залучення широкого спектра спеціалістів (неонатологів, педіатрів, ендокринологів, урологів, гінекологів, хірургів, онкологів, генетиків, психологів), а також соціальних працівників. Більшість цих пацієнтів консультовано відповідними спеціалістами провідних дитячих клінік м. Києва на вимогу лікарів зазначеної клініки. Враховано побажання батьків з прогнозуванням подальшого розвитку дитини та вирішення всіх медичних, соціальних і психологічних аспектів.

Комплексне обстеження хворих дітей:

1) огляд дитини;

2) сімейний анамнез;

3) медикаментозний анамнез (передусім - гормони);
4) генетичне обстеження (каріотип, статевий хроматин);

5) гормональні дослідження (стероїди крові і сечі, гормони гіпофіза, тестостерон, кортизол, адренокортикотропний гормон);

6) електроліти крові;

7) тест з хоріонічним гонадотропіном;

8) УЗД;

9) лапароскопія;

10) повздовжня біопсія гонад;

11) урогенітальна ендоскопія;

12) променеві методи обстеження (МРТ, КТ, генітографія).

Кожна дитина мала персональний план обстеження. Верифікація стану дитини тривала від декількох тижнів до 2-3 місяців.

Під час обстеження дітей, підготовки до операції та вибору плану хірургічної корекції враховано такі діагностичні та практичні критерії:

1. Діти з тяжкими формами гіпоспадії підлягають обов'язковому генетичному обстеженню.

2. Нормально сформоване в анатомічному та функціональному відношенні яєчко виробляє фетальний тестостерон, під впливом якого проходить розвиток вольфових структур (придатки яєчка, сім'яні пухирці, сім'явиносна протока) та інгібітор мюллерових протоків (МІС-мюллер інгібуюча субстанція), що стимулює зворотний розвиток мюллерових структур (піхва, матка, маткові труби). У дітей, яким проводили фемінізуючі операції, були відсутні чоловічі структури та наявні відносно добре розвинуті жіночі. Це вказувало на відсутність в організмі добре розвинутого і функціонуючого хоча 6 одного яєчка, за винятком дитини 3 синдромом Морріса.

3. Стартова генетична стать.

4. Вибір більш «природної», менш травматичної корекції для кожного конкретного випадку.

5. Можливість вести статеве життя в майбутньому.

6. Можливість мати потомство, враховуючи сучасні технології запліднення.

7. Онкологічна небезпека.

8. Замісна гормонотерапія в майбутньому під контролем гінекологів та ендокринологів.

9. Побажання батьків.

Консиліумне вирішення всіх складних питань для кожного конкретного випадку тяжких РСР, узгодження всіх суперечливих аспектів з батьками та самими пацієнтами, допомога соціальних служб забезпечили обнадійливий результат роботи. $€$ розуміння неможливості дочасного вирішення майбутніх проблемних питань. Моделюється 
подальший розвиток дитини, складається план наступних обстежень і консервативного лікування, а можливо, і хірургічного.

\section{Висновки}

Народження дитини з тяжкою формою РСР є надзвичайно серйозною проблемою для батьків, медиків, психологів і соціальних працівників.

Порушення статевої диференціації дитини потребує педантичного розширеного комплексного обстеження із залученням широкого кола спеціалістів, які займаються питаннями статі, для верифікації вади та визначення найраціональнішого шляху у вирішенні проблеми, у т.ч. способу хірургічної корекції.

Дані статистики та власний досвід вказують на вищу частоту хірургічної корекції за «жіночим» типом у таких випадках.

Під час корекції фемінізуючого типу найтяжчим етапом у технічному розумінні є резекція печеристих тіл статевого органа з кліторопластикою та транслокацією клітора, найвідповідальнішим етапом у функціональному відношенні є кольпопластика.

Хірургічне лікування не є завершальним етапом лікування таких пацієнтів. Діти з РСР у подальшому потребують постійного динамічного спостереження гінекологів, урологів, онкологів, ендокринологів, психологів з відповідною корекцією терапії.
Між батьками та лікарями має бути цілковита гармонія у взаєминах для забезпечення дитині гідного життя, повноцінної психологічної та соціальної адаптації, можливості створення сім’ї та виховання наступного покоління.

Автори заявляють про відсутність конфлікту iнmересів.

\section{References/Лiтература}

1. AbouZeid Amr Abdelhamid. (2020). Feminizing genitoplasty in childhood: aiming for achievable outcomes. Springer. Annals of Pediatric Surgery. 16 (1): 34.

2. Conn J, Gillam L, Conway G. (2005). Revealing the diagnosis of androgen insensitivity syndrome in adulthood. BMJ.

3. Dreger AD, Chase C, Sousa A, Grupposo PA, Frader J. (2005). Changing the nomenclature/taxonomy for intersex: a scientific and clinical rationale. J Pediatr Endocrinol Metab.

4. Hindmarsh PC, Geertsma K. (2017, April). Congenital Adrenal Hyperplasia. Academic Press.

5. Lee PA, Houk CP, Faisal SA, Hughes IA. (2006, Aug). In collaboration with the participants in the International Consensus Conference on Intersex organized by the Lawson Wilkins Pediatric Endocrine Society and the European Society for Paediatric Endocrinology Pediatrics. Consensus Statement on Management of Intersex Disorders.

6. Ramani P, Yeung CK, Habeebu SS. (1993). Testicular intratubular germ cell neoplasia in children and adults with intersex. Am J Surg Pathol.

7. Waterloos M, Claeys T, Sempels M, Van Laecke E, Hoebeke P, Spinoit AF. (2018, Apr). Genitoplasty in newborn females with adrenogenital syndrome: Focus on the reconstruction technique and its outcomes. J Pediatr Urol: 14.

8. Wisniewski AB, Migeon CJ, Meyer-Bahlburg HF et al. (2000). Complete androgen insensitivity syndrome: long-term medical, surgical, and psychosexual outcome. J Clin Endocrinol Metab.

\footnotetext{
Відомості про авторів:

Почюрко Андрій Романович - дитячий уролог вищої кат. І-го хірургічного та поліклінічного відділень КНП ЛОР ЛОДКЛ «ОХМАТДИТ», гол. експерт з дитячої урології ДОЗ ЛОДА. Адреса: м. Львів, вул. Лисенка, 31; тел. +38 (032) 275-93-34. https://orcid.org/0000-0003-3147-0534.

Гримак Ігор Ярославович - дитячий уролог вищої кат. І-го хірургічного відділення КНП ЛОР ЛОДКЛ «ОХМАТДИТ». Адреса: м. Львів, вул. Лисенка, 31. https://orcid.org/0000-0002-7671-5198.

Гельнер Надія Володимирівна - к.мед.н., зав. медико-генетичним центром ДУ «Інститут спадкової патології НАМН України», лікар генетик вищої кат. Адреса: м. Львів, вул. Лисенка, 31 .

Гижа Богдан Ігорович - дитячий уролог вищої кат. І-го хірургічного відділення КНП ЛОР ЛОДКЛ «ОХМАТДИТ». Адреса: м. Львів, вул. Лисенка, 31. Івасвкевич Данило Зеновійович - дитячий уролог I кат. І-го хірургічного відділення КНП ЛОР ЛОДКЛ «ОХМАТДИТ». Адреса: м. Львів, вул. Лисенка, 31. https://orcid.org/0000-0002-2026-8210.

Чайківсвка Еліна Флавіанівна - д.мед.н., лікар - дитячий гінеколог вищої кат. І-го хірургічного відділення КНП ЛОР ЛОДКЛ «ОХМАТДИТ», дои. каб. акушерства, гінекології та перинатології ФПДО Львівського НМУ імені Д. Галицького. Адреса: м. Львів, вул. Лисенка, 31.

Гижа Лілія Юрївна - к.мед.н., асистент каф. дитячої хірургії Львівського НмУ імені Д. Галицького, лікар - дитячий хірург вищої кат. І-го хірургічного відділення КНП ЛОР ЛОДКЛ «ОХМАТДИТ». Адреса: м. Львів, вул. Лисенка, 31.

Стеник Роман володимирович - дитячий хірург вищої кат., Засл. лікар Украйни, зав. І-го хірургічного відділення КНП ЛОР ЛОДКЛ «ОХМАТДИТ». Адреса: м. Львів, вул. Лисенка, 31.

Дворакевич Андрій Орестович - дитячий хірург вищої кат. І-го хірургічного відділення КНП ЛОР ЛОДКЛ «ОХМАТДИТ», керівник Центру малоінвазивноїхірургіі. Адреса: м. Львів, вул. Лисенка, 31.

Поиюрко Роман Андрійович - лікар - дитячий хірург І хірургічного відділення КНП ЛОР ЛОДКЛ «ОХМАТДИТ». Адреса: м. Львів, вул. Лисенка, 31. https://orcid.org/000-0003-2215-9904.
}

Глуико Зеновій Іванович - дитячий уролог вищої кат. КНП ДМР Дрогобицька міська поліклініка. Адреса: м. Дрогобич, вул. Січових Стрільців, 22. 


\title{
Ю.М. Гук, А.М. Зима, Т.А. Кінча-Поліщук, А.І. Чеверда, О.Ю. Скуратов, Р.В. Видерко, А.В.Зотя \\ Результати комплексного лікування пацієнтів із синдромом Джаффе-Кампаначчі
}

\author{
ДУ «Інститут травматологї та ортопедії НАМН Украӥни», м. Київ
}

Paediatric surgery.Ukraine.2021.3(72):69-75; doi 10.15574/PS.2021.72.69

For citation: Guk YM, Zyma AM, Kincha-Polishchuk TA, Chewerda Al et al.(2021). The results of complex treatment of patients with Jaffe-Campanacci syndrome. Paediatric Surgery.Ukraine. 3(72):69-75; doi 10.15574/PS.2021.72.69.

Пацієнтам із синдромом Джаффе-Кампаначчі (СДК) притаманна ортопедична патологія, провідними симптомами якої є больовий синдром у кістках, їх осьова деформація, порушення стану кісткової тканини та ії метаболізму. Питання хірургічних втручань, що стосуються осьових деформацій і патологічних переломів кісток, а також медикаментозної антиостеопоротичної терапії, спрямованої на корекцію змін структурно-функціонального стану кісткової тканини при цьому захворюванні, недостатньо вивчені та потребують удосконалення.

Мета - удосконалити методи ортопедичного лікування пацієнтів із СДК для зниження в них больового синдрому, поліпшення стану кісткової тканини та їі метаболізму.

Матеріали та методи. У відділенні травматології та ортопедії дитячого віку ДУ «Інститут травматології та ортопедії НАМН України» в період 2015-2020 рр. на лікуванні перебували 9 пацієнтів із СДК (з ураженням великогомілкової кістки - 8 хворих, з ураженням ліктьової кістки - 1 хвора), яким проведено лікування патології опорно-рухового апарату: медикаментозну антиостеопоротичну терапію, зокрема, із застосуванням антирезорбентів (препаратів памідронової кислоти) - у 5 пацієнтів; хірургічний метод лікування - у 8 хворих - профілактичний металоостеосинтез (МОС) ураження кісток або коригувальні остеотомії із застосуванням МОС. Вік пацієнтів становив від 6 до 12 років. Аналіз результатів ортопедичного лікування проведено на підставі оцінки зниження больового синдрому шляхом застосування візуально-аналогової шкали, поліпшення стану кісткової тканини та ії метаболізму шляхом дослідження мінеральної щільності кісткової тканини і маркерів кісткового обміну на початку та в процесі лікування; ступеня корекції деформації кістки та відновлення осі кінцівки.

Результати. Наведено обгрунтування, загальні принципи та особливості ортопедичного лікування пацієнтів із СДК, що передбачало: антиостеопоротичну терапію - показання та протипоказання; розрахунок доз і схеми застосування тих чи інших препаратів, у тому числі з групи бісфосфонатів; хірургічне лікування - показання та протипоказання, особливості технічного виконання хірургічних профілактичних MOC і коригувальних остеотомій з МОС, застосування удосконалених інтрамедулярних телескопічних металоконструкцій.

Зазначену медикаментозну терапію успішно апробовано в 4 пацієнтів із СДК. Успішність проведеного лікування підтверджено зменшенням / усуненням больового синдрому, призупиненням прогресування патологічних вогнищ у кістках нижніх кінцівок, поліпшенням структурного стану кісткової тканини та їі метаболізму. Аналіз хірургічного методу лікування вказує на його задовільні результати в усіх 8 оперованих пацієнтів із СДК - досягнуто зрощення та корекції осі кінцівки після коригувальних остеотомій, відновлено опороздатність, відмічено відсутність рецидиву деформації кістки та прогресування патологічних вогнищ.

Висновки. Результати комплексного ортопедичного лікування пацієнтів із СДК вказують на доцільність його застосування, про що свідчить усунення / зменшення больового синдрому, поліпшення структурного стану кісткової тканини та її метаболізму, призупинення прогресування захворювання, досягнення зрощення після коригувальних остеотомій у всіх випадках, усунення осьових деформацій кісток, покращення функції ходьби та пересування пацієнтів. 
Дослідження виконано відповідно до принципів Гельсінської декларації. Протокол дослідження ухвалено Локальним етичним комітетом зазначених у роботі установ. На проведення дослідження отримано інформовану згоду батьків дітей.

Автори заявляють про відсутність конфлікту інтересів.

Ключові слова: синдром Кампаначчі, деформації кісток, медикаментозна терапія, бісфосфонати, препарати памідронової кислоти, коригувальні остеотомії, металоостеосинтез.

\section{The results of complex treatment of patients with Jaffe-Campanacci syndrome Y.M. Guk, A.M. Zyma, T.A. Kincha-Polishchuk, A.I. Chewerda, O.Y. Skuratov, A.V. Zotia \\ SI «The Institute of Traumatology and Orthopedics» of the NAMS of Ukraine, Kyiv}

Patients with Jaffe-Campanacci syndrome have orthopedic pathology, the leading symptoms of which are bone pain, their axial deformation, disorders of bone tissue and its metabolism. The issues of surgical interventions related to axial deformities and pathological bone fractures, as well as drug antiosteoporotic therapy aimed at correcting changes in the structural and functional state of bone tissue in this disease, are insufficiently studied and need improvement.

The aim is to improve ortopedic treatment of patients with Jaffe-Campanacci syndrome to reduce their pain, improve the condition of bone tissue and its metabolism.

Materials and methods. In the department of pediatric traumatology and orthopedics of the State Institution «Institute of Traumatology and Orthopedics of the National Academy of Medical Sciences of Ukraine») in the period 2015-2020, 9 patients with Jaffe-Campanacci syndrome (with a tibial lesion - 8 cases, with a liquid bone lesion -1 case) were used for research, which were carried out for the treatment of pathologies of the musculoskeletal system: drug anti-osteoporotic therapy, in particular, with the use of anti-resorbents (drugs - pamidron) 5 requests; surgical method of treatment - in 8 methods - prophylactic metal osteosynthesis of bone lesions or the use of osteotomies using. Age of patients varied from 6 to 12 years. Analysis of the results of orthopedic treatment based on assessments using a larger syndrome using a visual analog scale, improvement of bone tissue and its metabolism in the study of bone mineral density and markers of bone metabolism at the beginning and during treatment; the correction degree of the bone deformation and the restoration of the limb axis.

Results. The substantiation, general principles and features of orthopedic treatment of patients with Jaffe-Campanacci syndrome are given, which included: anti-osteoporotic therapy - indications and contraindications; calculation of doses and schemes of application of these or those drugs, including from group of bisphosphonates; surgical treatment - indications and contraindications, features of technical performance of surgical prophylactic and corrective osteotomies with, application of advanced intramedullary telescopic metal structures.

This drug therapy has been successfully tested in 4 patients with Jaffe-Campanacci syndrome. The success of the treatment was confirmed by the reduction/ elimination of pain, stopping the progression of pathological foci in the bones of the lower extremities, improving the structural condition of bone tissue and its metabolism. Analysis of the surgical treatment indicated its satisfactory results in all 8 operated patients with Jaffe-Campanacci syndrome - achieved fusion and correction of the limb axis after corrective osteotomies, restored capacity, no recurrence of bone deformity and progression of pathological foci. Conclusions. The results of complex orthopedic treatment of patients with Jaffe-Campanacci syndrome indicate the feasibility of its use, as evidenced by the elimination / reduction of pain, improving the structural condition of bone tissue and its metabolism, stopping disease progression, achieving healing after corrective osteotomies in all cases, elimination of patients' axial deformities, improving of walking and moving abilities.

The study was conducted in accordance with the principles of the Declaration of Helsinki. The research protocol was approved by the Local Ethics Committee of the institutions mentioned in the work. Parental informed consents were obtained for the study.

The authors declare no conflict of interest.

Key words: Jaffe-Campanacci syndrome, bone deformities, drug therapy, bisphosphonates, pamidronic acid medications, corrective osteotomies, metal osteosynthesis.

\section{Результаты ортопедического лечения пациентов с синдромом Джаффе-Кампаначчи Ю.М. Гук, А.М. Зима, Т.А. Кинча-Полищук, А.И. Чеверда, А.Ю. Скуратов, Р.В. Видерко, А.В. Зотя}

ГУ «Институт травматологии и ортопедии НАМН Украины», г. Киев

Пациентам с синдромом Джаффе-Кампаначчи (СДК) присуща ортопедическая патология, ведущими симптомами которой является болевой синдром в костях, их осевая деформация, нарушение состояния костной ткани и ее метаболизма. Вопрос хирургических вмешательств, касающихся осевых деформаций и патологических переломов костей; медикаментозной антиостеопоротической терапии, направленной на коррекцию изменений структурно-функционального состояния костной ткани при данном заболевании, недостаточно изучены и требуют совершенствования. Цель - усовершенствовать методы ортопедического лечения пациентов с СДК для снижения у них болевого синдрома, улучшения состояния костной ткани и ее метаболизма.

Материалы и методы. В отделении травматологии и ортопедии детского возраста ГУ «Институт травматологии и ортопедии НАМН Украины» в период 2015-2020 гг. на лечении находилось 9 пациентов с СДК (с поражением большеберцовой кости - 8 больных, с поражением локтевой кости - 1 больной), которым проведено лечение патологии опорно-двигательного аппарата: медикаментозная антиостеопоротическая терапия, В том числе с применением антирезорбентов (препаратов памидроновой кислоты) - у 5 пациентов; хирургический метод лечения - у 8 больных профилактический металлоостеосинтез (МОС) поражения костей или коррекционные остеотомии с применением МОС. Возраст пациентов составил от 6 до 12 лет. Анализ результатов ортопедического лечения проведен на основании оценки снижения болевого синдрома путем применения визуальной аналоговой шкалы, улучшения состояния костной ткани и ее метаболизма путем исследования минеральной плотности костной ткани и маркеров костного обмена в начале и в процессе лечения, степени коррекции деформации кости и восстановления оси конечности.

Результаты. Представлены обоснования, общие принципы и особенности ортопедического лечения пациентов с СДК, включающего: антиостеопоротичну терапию - показания и противопоказания; расчеты доз и схемы применения тех или иных препаратов, в том числе из группы бисфосфонатов; хирургическое лечение - показания и противопоказания, особенности технического выполнения хирургических профилактических МОС и коррекционных остеотомий с МОС, применение усовершенствованных интрамедулярных телескопических металлоконструкций. Представленная медикаментозная терапия успешно апробирована у 4 пациентов с СДК. Успешность проведенного лечения подтверждена уменьшением / устранением болевого синдрома, приостановлением прогрессирования патологических очагов в костях нижних конечностей, 
улучшением структурного состояния костной ткани и ее метаболизма. Анализ хирургического метода лечения указывает на его удовлетворительные результаты у всех 8 оперированных пациентов с СДК - достигнуты сращение и коррекция оси конечности после коррекционных остеотомий, восстановлена опороспособность, отсутствие рецидива деформации кости и прогрессирования патологических очагов,

Выводы. Результаты комплексного ортопедического лечения пациентов с СДК указывают на его эффективность и целесообразность применения, о чем свидетельствуют устранение или уменьшение болевого синдрома, улучшение структурного состояния костной ткани и ее метаболизма, приостановление прогрессирования заболевания, достижение сращения после коррекционных остеотомий во всех случаях, устранение осевых деформаций костей, улучшение функции ходьбы и передвижения пациентов.

Исследование выполнено в соответствии с принципами Хельсинкской декларации. Протокол исследования одобрен Локальным этическим комитетом указанных в работе учреждений. На проведение исследования получено информированное согласие родителей детей.

Авторы заявляют об отсутствии конфликта интересов.

Ключевые слова: синдром Кампаначчи, деформации костей, медикаментозная терапия, бисфосфонаты, препараты памидроновой кислоты, коррекционные остеотомии, металлоостеосинтез.

Відомо, що синдром Джаффе-Кампаначчі (СДК) являє собою неосифіковані фіброми, що переважно уражують метафізи довгих трубчастих кісток. Скелетні аномалії часто поєднуються з позаскелетною патологією (наявність плям «café-au-lait», патологія зору, аномалії серцево-судинної системи, крипторхізм або гіпогонадизм) [2,7]. СДК належить до групи вроджених диспластичних захворювань скелету з ураженням переважно великогомілкової кістки, має прогресуючий перебіг із формуванням деформацій та патологічних переломів [1,2,4].

Перші публікації, в яких згадується термін «кістково-фіброзна дисплазія», належать Jaffe та Lichtenstein, які описали комбінацію клінічних проявів неосифікованих фібром і нейрофіброматозу 1-го типу в одного пацієнта у 1942 р. Пізніше, у 1983 р., італійський онкоортопед М. Campanacci [2] вказав на певні морфологічні відмінності СДК від моноосальної форми звичайної фіброзної дисплазії (ФД) і нейрофіброматозу 1-го типу (НФ1) та наголосив на необхідності розглядати це захворювання як окрему нозологічну одиницю. Протягом тривалого часу ці зауваження були без достатньої уваги наукової спільноти і лише у 1993 р., після виходу праці «Атлас патології пухлин» (автори - R.E. Fechner, S.E. Mills), СДК виділили в окреме захворювання кісток, що знайшло відображення в Міжнародній гістологічній класифікації Всесвітньої організації охорони здоров'я $[3,9]$. Останні молекулярно-генетичні дослідження встановили, що Gs-альфамутації в Arg201-кодону, характерні для ФД, відсутні у хворих з СДК [10]. Проте виявили генні мутації, притаманні НФ1. Отримані дані показали, що ці захворювання мають різні етіологічні фактори і потребують подальшого вивчення.

Аналіз результатів хірургічного лікування хворих на СДК «класичними» методиками у вигляді металоостеосинтезу (MOC) накістковими пластинами вказав на їх низьку ефективність, наявність значної кількості рецидивів деформації кісток та їх патологічних переломів. Враховуючи значний відсоток ускладнень, автори порекомендували режим дина- мічного спостереження за клініко-рентгенологічними проявами розвитку захворювання до виникнення значних деформацій кісток [8]. Проте враховуючи прогресуючий характер захворювання, ортопеди всього світу використовують також консервативне лікування із застосуванням препаратів памідронової кислоти [5,6,9].

Отже, на сьогодні $€$ певні досягнення в розумінні діагностики СДК, проте недостатньо вирішеним залишається питання лікувальної тактики. Відсутність чіткої тактики консервативного і хірургічного лікування вказує на необхідність удосконалення цих методів лікування.

Мета дослідження - поліпшити результати лікування пацієнтів із СДК шляхом висвітлення й удосконалення медикаментозної терапії та нових методів хірургічного лікування ортопедичної патології в цієї категорії пацієнтів.

\section{Матеріали та методи дослідження}

Під нашим спостереженням в ДУ «Інститут травматології та ортопедії НАМН України» перебували 9 хворих із СДК віком від 5 до 14 років 6 пацієнтів чоловічої статі, 3 - жіночої).

Методи дослідження: клінічний, рентгенографічний, біохімічний, рентгенденситометричний, статистичний.

Під час клінічного обстеження оцінено больовий синдром, його локалізацію, інтенсивність, зв'язок із фізичною активністю пацієнта, наявність деформації та іiї ступеня, стан шкірних покривів, функції суміжних суглобів.

Діагноз встановлено за результатами рентгенологічного дослідження сегмента кінцівки з суміжними суглобами у стандартній передньо-задній та боковій проєкціях (апарат «Multix UP»). Визначено локалізацію, обсяг ураження, структурні зміни кортексу, осьові параметри сегмента кінцівки та їх відповідність віковим нормам.

У 8 пацієнтів діагностовано ураження великогомілкової кістки, в 1 хворого - ліктьової кістки передпліччя. 
Усім пацієнтам проведено дослідження структурно-функціонального стану кісткової тканини (СФСКТ). Кістковий метаболізм вивчено в усіх хворих з СДК, яким проведено медикаментозну терапію шляхом дослідження маркерів кісткоутворення (totalP1NP), остеорезорбції ( $\beta$-CrossLaps ( $\beta$-CTx)) та циклу ремоделювання (остеокальцин). Також досліджено рівень вітаміну 25(OH)D (вітамін D загальний) як маркера гормональної ланки ремоделювання кісткової тканини. Дослідження проведено методом імуноферментного аналізу на аналізаторі «Elecsys» фірми «Roche»(«RocheDiagnostics», Німеччина) в умовах лабораторії клінічної фізіології та патології опорно-рухового апарату ДУ «Інститут геронтології НАМН України» за допомогою тестсистем «Cobas». Мінеральну щільність кісткової тканини (МЩКТ) досліджено шляхом застосування рентгенденситометричного методу дослідження та оцінки T- і Z-критерію в пацієнтів, яким призначено препарати памідронової кислоти.

Усім пацієнтам проведено комплексні лікувальні заходи: медикаментозну корекцію порушень СФСКТ, хірургічні методи лікування.

Медикаментозну антиостеопоротичну терапію застосовано 4 хворим із СДК. Усім пацієнтам проведено базисну антиостеопоротичну терапію препаратами кальцію і вітаміну D та призначено обов'язкове дослідження рівня кальцію і вітаміну D в сироватці крові, як до, так і під час лікування. Хворим із вираженим больовим синдромом у кістках i після хірургічних втручань із приводу ураження великогомілкової кістки проведено антиостеопоротичну терапію, в основі якої, крім базисних, використано препарати памідронової кислоти (ППК).

Хірургічний метод лікування застосовано 9 хворим із СДК. Вибір методики хірургічного лікування залежав від віку пацієнта, обсягу ураження та поширеності патологічних змін, наявності перелому або деформації кісток гомілки чи передпліччя.

9 хворим із СДК проведено 14 оперативних втручань. Коригувальну остеотомію великогомілкової кістки проведено 5 хворим (середній вік - 5 років), 3 них у поєднанні з МОС накістковою пластиною 3 хворим, а 1 хворому виконано первинний МОС телескопічним «ростучим» інтрамедулярним стержнем. 2 хворим виконано реостеосинтез із застосуванням телескопічного «ростучого» інтрамедулярного стержня. 1 пацієнтові проведено заміну «ростучого» інтрамедулярного стержня ураженої великогомілкової кістки, у зв'язку з ростом пацієнта, та відкриту біопсію патологічного вогнища з його патоморфологічним дослідженням, у зв'язку з пі- дозрою на злоякісність патологічного вогнища. 1 пацієнтці з ураженням ліктьової кістки проведено профілактичний MOC LSP ліктьової кістки та в подальшому, у зв'язку з прогресуванням вогнища ураження ліктьової кістки та виникненням ії деформації, - коригувальну остеотомію з аутопластикою трансплантатом із малогомілкової кістки та МОС LSP ліктьової кістки.

Результати комплексного ортопедичного лікування оцінено за клінічними та параклічними даними. Аналіз медикаментозної терапії проведено за даними клінічного дослідження - зменшення/усунення больового синдрому (зниження балів за візуально-аналоговою шкалою (ВАШ), яку застосовано в пацієнтів віком від 10 років); параклінічними даними - зниження рівня $\beta$-CrossLaps у сироватці крові за 6-12 місяців і підвищення рівня Z-критерію поперекового відділу хребта за 1 рік від початку лікування. Аналіз результатів хірургічного лікування проведено шляхом оцінки досягнення зрощення при виконанні коригувальних остеотомій, попередження рецидивів деформації та виникнення патологічних переломів, прогресування патологічного осередку кістки, досягнення опірності кінцівки та поліпшення ії функції.

\section{Результати дослідження та їх обговорення}

Лікування патології опорно-рухового апарату в 9 пацієнтів із СДК залежало від вираженості клінічних проявів (біль в ураженому сегменті, деформація великогомілкової кістки, прогресування патологічного вогнища, зміни СФСКТ) та проводилось у вигляді: медикаментозної терапії в комбінації з хірургічними втручаннями (4 пацієнти); самостійної медикаментозної терапії, у разі, якщо не показані хірургічні втручання (відсутність деформації кістки) або $€$ протипоказання до проведення останніх (1 хворий); лише хірургічного лікування (4 пацієнти), що пов'язано з відсутністю впровадженої системи медикаментозної терапії бісфосфонатами на момент ортопедичних втручань у цієї категорії пацієнтів.

Показаннями до застосування лише медикаментозної терапії були скарги на біль в ураженій кінцівці, патологічне вогнище у великогомілковій кістці, зокрема його прогресування (збільшення в об'ємі та погіршення структури) без значної деформації. Показаннями до комбінації медикаментозної терапії порушень СФСКТ і хірургічного методу лікування були такі симптоми: біль в ураженій кінцівці, порушення функції ходьби та опори, деформації кісток, прогресування патологічного вогнища кістки, диференційна діагностика патологічних вогнищ ураженої кістки зі злоякісними новоутвореннями. 
Таблиця

Результати клінічного, рентгенденситометричного дослідження, маркерів кісткового обміну в пацієнтів із синдромом Джаффе-Кампаначчі, яким проведено медикаментозну терапію препаратами памідронової кислоти

\begin{tabular}{|c|c|c|c|c|c|c|c|c|c|c|c|c|c|c|c|c|c|}
\hline \multirow[b]{3}{*}{ 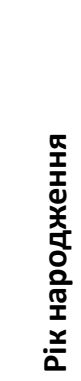 } & \multirow[b]{3}{*}{ 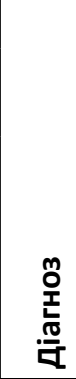 } & \multicolumn{8}{|c|}{ До лікування } & \multicolumn{8}{|c|}{ Після лікування } \\
\hline & & \multicolumn{3}{|c|}{ денситометрія } & \multicolumn{4}{|c|}{$\begin{array}{l}\text { маркери кісткового обміну } \\
\text { до лікування }\end{array}$} & \multirow[b]{2}{*}{ 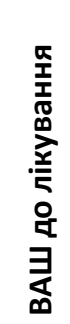 } & \multicolumn{3}{|c|}{ денситометрія } & \multicolumn{4}{|c|}{$\begin{array}{l}\text { маркери кісткового об- } \\
\text { міну після лікування }\end{array}$} & \multirow{2}{*}{ 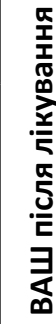 } \\
\hline & & 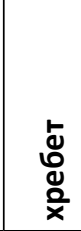 & 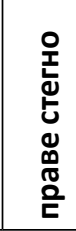 & 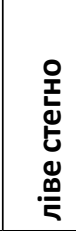 & $\frac{a}{a}$ & $\stackrel{\log }{>}$ & 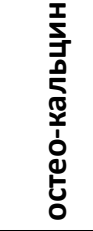 & $\begin{array}{l}\frac{n}{0} \\
\frac{0}{0} \\
\frac{0}{U} \\
0 \\
0\end{array}$ & & $\begin{array}{l}\stackrel{๖}{0} \\
\stackrel{d}{0} \\
\frac{0}{x}\end{array}$ & 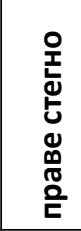 & 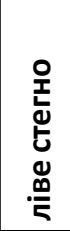 & 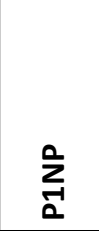 & $\stackrel{\log }{>}$ & 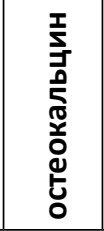 & $\begin{array}{l}\frac{n}{0} \\
\frac{0}{0} \\
\frac{0}{U} \\
0\end{array}$ & \\
\hline \multirow[t]{2}{*}{2010} & \multirow[t]{2}{*}{ СДК } & \multirow[t]{2}{*}{$-0,9$} & \multirow[t]{2}{*}{$-2,5$} & \multirow[t]{2}{*}{$-1,1$} & 1057 & 12,48 & 141,7 & 1,85 & \multirow[t]{2}{*}{1} & & & & \multirow[t]{2}{*}{764,5} & \multirow[t]{2}{*}{55} & \multirow[t]{2}{*}{97,4} & \multirow[t]{2}{*}{1,91} & \multirow[t]{2}{*}{0} \\
\hline & & & & & 929,1 & 10,14 & 105 & 3,23 & & & & & & & & & \\
\hline \multirow[t]{2}{*}{2005} & \multirow[t]{2}{*}{ СДК } & $-0,5$ & $-0,2$ & $-1,6$ & & \multirow[t]{2}{*}{19,7} & \multirow[t]{2}{*}{21,94} & \multirow[t]{2}{*}{3,35} & \multirow[t]{2}{*}{1} & \multirow[t]{2}{*}{$-0,6$} & \multirow[t]{2}{*}{$-0,2$} & \multirow[t]{2}{*}{$-1,4$} & \multirow[t]{2}{*}{653,2} & \multirow[t]{2}{*}{23,56} & \multirow[t]{2}{*}{137,8} & \multirow[t]{2}{*}{2,49} & \multirow[t]{2}{*}{0} \\
\hline & & $-0,4$ & $-0,6$ & 1,8 & & & & & & & & & & & & & \\
\hline 2009 & СДК & $-0,5$ & $-0,9$ & $-0,4$ & 400 & 16,8 & 78,5 & 2,77 & 3 & & & & & 39,3 & & 1,98 & 2 \\
\hline 2008 & СДК & $-0,5$ & -1 & $-3,5$ & 879,5 & 62,02 & 75,07 & 1,64 & 4 & $-0,4$ & $-0,8$ & $-1,5$ & 573,3 & & 17,1 & 1,31 & 3 \\
\hline
\end{tabular}

Метою комбінованого ортопедичного лікування (медикаментозна терапія і хірургічні методи лікування) було зменшення остеорезорбції та збільшення кісткової маси ураженої кістки, усунення деформації кістки, що призводить до зменшення/ зникнення больового синдрому, призупинення прогресування вогнищ остеодисплазії або до їх регресування, покращення функції ходьби та опори.

Усім пацієнтам із комплексним ортопедичним лікуванням медикаментозну терапію застосовано після хірургічних втручань.

Залежно від змін СФСКТ пацієнтам призначено базисну терапію в комбінації з препаратами ППК. Нормальний рівень Са сироватки крові був однією з умов для призначення терапії ППК (Са сироватки крові не нижче 2,4 ммоль/л). ППК застосовано в дозі 0,5-1,0 мг/кг/добу протягом 1-2-3 діб з інтервалом між циклами інфузій 3-4 місяці протягом від 9 місяців до 15 місяців. Усі пацієнти отримували базисну терапію: кальцемін по 1-2 таблетки на добу і вітамін D в дозі 1000-2000 MO на добу незалежно від змін СФСКТ протягом усього терміну лікування.

Базисну терапію в сукупності із ППК у дозі 0,5 мг/кг ваги призначено 1 пацієнтові з незначно вираженим больовим синдромом і невеликою площею ураження великогомілкової кістки, $\beta$-CrossLaps 1,5 нг/мл (від 0,5 нг/мл до 1,5 нг/мл), Z-критерій $0,9 \mathrm{SD}$ (від -1,1 до -1,5 SD).

Базисну терапію в комбінації із ППК у дозі 1 мг/кг ваги застосовано 3 пацієнтам із вираженим больовим синдромом і значною площею ураження великогомілкової кістки при СК зі змінами показників $\beta$-CrossLaps від 1,5 і вище нг/мл, Z-критерію від - 1,5 SD і нижче.
Батьки усіх пацієнтів, які отримували ППК, дали інформаційну згоду на проведення медикаментозної терапії. Успішність медикаментозної терапії оцінено за зниженням рівня $\beta$-CrossLaps у сироватці крові пацієнтів за 6 міс, зменшенням або зникненням больового синдрому та підвищенням рівня Z-критерію поперекового відділу хребта за 1 рік від початку лікування. Терміни для оцінки ефективності терапії визначено згідно з рекомендаціями Міжнародної асоціації остеопорозу.

Після медикаментозної терапії у 2 пацієнтів із СДК (табл.) зменшилася інтенсивність больового синдрому, а у 2 хворих біль зник повністю. У всіх пацієнтів поліпшилася структура кісткової тканини в місці патологічного вогнища, про що свідчать показники СФСКТ. За даними таблиці, у пацієнтів із СДК до лікування відмічалися високі значення

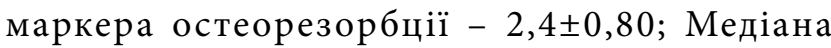
$(25-75 \%)=2,3(1,75-3,0) ;(1-и ̆$ хворий - 1,64 нг/мл; 2 -й хворий - 2,77 нг/мл; 3-й хворий - 3,23 нг/мл, 4-й хворий $-3,35$ нг/мл), що свідчить про значну остеокластичну активність. Проте поліпшення рентгенденситометричного показника (Z-критерій, $-3,5 \mathrm{SD})$ спостерігалося лише в 1 пацієнта на ураженій кінцівці. Після терапії за 6-12 місяців у пацієнтів у всіх випадках знизився рівень $\beta$-CrossLaps до 1,92 0 ,48; Медіана $(25-75 \%)=1,94(1,60-2,24)$, $\mathrm{p}=0,144$ (1-й хворий - 1,31 нг/мл; 2-й хворий 1,98 нг/мл; 3-й хворий - 1,91 нг/мл; 4-й хворий 2,49 нг/мл) від 18,7\% до 41\% у різних випадках. В 1 пацієнта з СДК після терапії значно поліпшилася МЩКТ на боці ураження, про що свідчить зміна Z-критерію з -3,5 до 1,8 SD. 
Аналізуючи дані пацієнтів із СДК, слід зазначити, що найбільше зниження в сироватці крові $\beta$-CrossLaps та нормалізація остеорезорбції при введенні ППК відмічалися у 2 пацієнтів, які мали найвищі показники до початку терапії (3,23-1,9 нг/мл; 3,35-2,49 нг/мл), що свідчить про активну «реакцію» кісткової системи на терапію при значному порушенні циклу ремоделювання кісткової тканини. При цьому у хворих на СДК спостерігалася невідповідність лабораторних і денситометричних показників - за незначного підвищення маркера остеорезорбції виражене зниження Z-критерію, що вказує на зменшення щільності кісткової тканини. Також у 2 пацієнтів, батьки яких відмовилися продовжувати терапію при досягненні терапевтичного ефекту після 2 інфузій, больовий синдром відновився або посилився, що спонукало знову почати терапію ППК і повторно досягнути зниження та нівелювання больового синдрому.

Серед 9 пацієнтів, яким виконано серію хірургічних втручань, у всіх випадках відмічалося поліпшення та відновлення функції ходьби й опори. 7 пацієнтам проведено профілактичний МОС, серед них у подальшому в 2 випадках - коригувальні остеотомії. У 2 пацієнтів виконано лише коригувальні остеотомії з МОС. У всіх випадках коригувальних остеотомій усунуто осьову деформацію, досягнуто зрощення кістки та відновлення функції ураженої кінцівки.

Але слід зауважити, що лише в разі відсутньої деформації ураженої кістки виконано профілактичний МОС - великогомілкової кістки в 6 пацієнтів (LSP-пластина - 4 пацієнти, інтрамедулярний телескопічний стержень, що «росте», - 1 пацієнт) і ліктьової кістки в 1 пацієнтки для попередження виникнення осьових деформацій у майбутньому. На превеликий жаль, досягнути ортопедичного результату за допомогою лише одного хірургічного втручання вдалося у 4 пацієнтів, серед інших 2 осіб: в 1 пацієнтки, у зв'язку з прогресуванням ураження кістки, їі ростом і виникненням деформації поза межами пластини, виконано вилучення фіксатора, коригувальну остеотомію ліктьової кістки з аутопластикою та MOC LSP-пластиною, досягнуто зрощення й відновлення функції верхньої кінцівки. В 1 хворого після неодноразового профілактичного MOC великогомілкової кістки (LSP-пластиною, інтрамедулярним телескопічним стержнем, що «росте»), у зв'язку з ростом кістки та прогресуванням іiі ураження, виникла деформація гомілки. Йому проведено коригувальну остеотомію кісток гомілки та MOC інтрамедулярним телескопічним стержнем, що «росте», досягнуто зрощення та відновлення функції ходьби й опори. Також у цього пацієнта, у зв'язку з прогресуванням захворювання і підозрою на малігнізацію, виконано відкриту біопсію патологічного ураження великогомілкової кістки, що підтвердило діагноз СК. Серед 2 пацієнтів, яким виконано коригувальні остеотомії кісток гомілки: в 1 пацієнта проведено MOC LSP-пластиною, проте у зв'язку з ростом дитини та деформацією, що виникла поза межами пластини, вилучено фіксатор, проведено повторну остеотомію та МОС інтрамедулярним телескопічним стержнем, що «росте», також у цього пацієнта з приводу вальгусної деформації в ділянці колінного суглобу і міграції телескопічної втулки інтрамедулярної конструкції проведено блокування проксимальної медіальної росткової зони великогомілкової кістки та елевацію і фіксацію телескопічної складової конструкції. В іншої хворої проведено MOC LSP-пластиною, але сповільнена консолідація, що виникла в ділянці остеотомії, потребувала кісткової автопластики. У цих пацієнтів досягнуто зрощення та відновлення ходьби й опори, термін спостереження - 5 років.

Слід наголосити, що вищезазначені профілактичні та реконструктивні хірургічні втручання супроводжуються виникненням значного спектра ускладнень: рецидиву осьових деформацій, сповільненої консолідації, міграції елементів конструкцій. На наш погляд, виникнення таких ускладнень пов'язане як із недосконалістю металоконструкцій, що використовуються для остеосинтезу, так і з ростом хворої дитини, прогресуванням вогнища ураження кістки. Для мінімізації виникнення ускладнень у разі застосування хірургічного методу лікування в пацієнтів iз СК слід надавати перевагу при МОС біомеханічно виправданим інтрамедулярним телескопічним конструкціям, що «ростуть».

На думку авторів, комплексний підхід до лікування ортопедичних проявів при СК із застосуванням усього спектра медикаментозних і хірургічних методів дає змогу досягнути успіху в зменшенні клінічних проявів, призупиненні прогресування основного захворювання, поліпшенні й відновленні функції ураженої кінцівки.

\section{Висновки}

Сучасний підхід до лікування патології опорно-рухового апарату в пацієнтів із СДК передбачає діагностику та корекцію порушень структурно-функціонального стану кісткової тканини із застосуванням комплексного ортопедичного лікування деформації кісток і профілактику їх виникнення. 
Результати медикаментозної антиостеопоротичної терапії пацієнтів з СДК із застосуванням ППК свідчать про їі успішність і доцільність, на що вказує: зменшення / усунення больового синдрому (за даними клінічного дослідження - зниження балів за ВАШ), призупинення й попередження прогресування патологічних вогнищ у великогомілковій кістці, поліпшення структурного стану кісткової тканини (за даними рентгенденситометричного дослідження - підвищення рівня Z-критерію) і метаболізму кісткової тканини (за даними біохімічного дослідження - зниження показника остеорезорбції $\beta$-CrossLaps).

Хірургічне лікування ортопедичних проявів при СДК $є$ ефективним методом профілактики та корекції деформації кісток - у всіх випадках коригувальних остеотомій досягнуто зрощення та усунення деформації уражених кісток, покращення якості ходьби та опори, функції кінцівки.

Застосування інтрамедулярних телескопічних «ростучих» конструкцій у пацієнтів дитячого віку, як при профілактичному, так і при лікувальному MOC, дає змогу попередити повторну деформацію кістки та їі патологічний перелом, проводити ефективну корекцію деформації кістки.

Автори заявляють про відсутність конфлікту інтересів.

\section{References/Лiтература}

1. Anwar Hau M, Fox EJ, Cates JM, Brigman BE, Mankin HJ. (2002, May). Jaffe-Campanacci syndrome a case report and review of the literature the journal of bone and joint surgery, incorporated.
2. Campanacci M, Laus M. (1983, Nov). Boriani multiple nonossifying fibromata with extraskeletal anomalies: a new syndrome? The journal of bone and joint surgery. 65-b: 5 .

3. Fechner RE, Mills SE. (1993). Atlas of tumor pathology: tumors of the bone and joints. Fascicle 8, 3rd series. Washington DC: Armed Forces Institute of Pathology: 145-150.

4. Jaffe H, Lichtenstein Louis. (1941). Non-osteogenic fibroma of bone, american journal of pathology: 18 .

5. Javaid MK, Boyce A, Appelman-Dijkstra N, Ong J et al. (2019). Best practice management guidelines forfibrous dysplasia/McCune-Albrightsyndrome: a consensus statement from theFD/MAS international consortium. Orphanet Journal of Rare Diseases. 14: 139. https://doi.org/10.1186/s13023019-1102-9.

6. Meier ME, van der Bruggen W, van de Sande MAJ, AppelmanDijkstra NM. (2021, Apr). Regression of fibrous dysplasia in response to denosumab therapy: A report of two cases. Bone Reports. 14: 101058. doi: 10.1016/j.bonr.2021.101058.

7. Shaji G, Menezes RJ. (2021, Mar). Symptomatic Nonossifying Fibroma: Is Prophylactic Fixation Warranted? Journal of Orthopaedic Association of South Indian States. 17; 2: 71-76. doi 10.4103/joasis.joasis_4_21.

8. Snetkov AI, Berchenko GN, Nechvolodova OL, Savkina LF. (1998). Diagnostika osteofibroznoy displazii u detey. Vestnik travmatologii i ortopedii im. N.N. Priorova. 1: 31-33. [Снетков АИ, Берченко ГН, Нечволодова ОЛ, Савкина ЛФ. (1998). Диагностика остеофиброзной дисплазии у детей. Вестник травматологии и ортопедии им. Н.Н. Приорова. 1:31-33]

9. Tripathy SK, Swaroop S, Velagada S, Priyadarshini D, Das RR, Satpathy AK, Kanhaiyalal A. (2020). Response to Zoledronic Acid Infusion in Children With Fibrous Dysplasia Frontiers in Pediatrics. 8: 582316.

10. Vannelli S, Buganza R, Runfola F, Mussinatto I, Andreacchio A, Sanctis L. (2020). Jaffe-Campanacci syndrome orneurofibromatosis type 1: a case report ofphenotypic overlap with detection of NF1gene mutation in non-ossifying fibroma Italian Journal of Pediatrics.

\section{Відомості про авторів:}

Гук Юрій Миколайович - д.мед.н., проф., зав. відділу травматології та ортопедії дитячого віку дУ «Інститут травматології та ортопедії дитячого віку НАМН України». Адреса: м. Київ, вул. Бульварно-Кудрявська, 27; тел. (044) 486-79-44. https://orcid.org/0000-0002-4213-3560.

Зима Андрій Миколайович - д.мед.н., ст.н.с. відділу травматології та ортопедії дитячого віку ДУ «Інститут травматології та ортопедії дитячого віку НАМН України». Адреса: м. Київ, вул. Бульварно-Кудрявська, 27; тел. (044) 486-29-73. https://orcid.org/0000-0001-5443-2499.

Кінча-Полімук Тамара Анатоліївна - к.мед.н., пров.н.с. відділу травматології та ортопедії дитячого віку ДУ «Інститут травматології та ортопедії дитячого віку НАМН України». Адреса: м. Київ, вул. Бульварно-Кудрявська, 27; тел. (044) 486-29-73. https://orcid.org/0000-0002-7632-5796.

Чеверда Андрій Іванович - к.мед.н., ст.н.с. відділу травматології та ортопедії дитячого віку ДУ «Інститут травматології та ортопедії дитячого віку НАМН України». Адреса: м. Київ, вул. Бульварно-Кудрявська, 27; тел. (044) 486-29-73. https://orcid.org/0000-0002-7632-8278.

Скуратов Олександр Юрійович - лікар ортопед-травматолог відділу травматології та ортопедії дитячого віку ДУ «Інститут травматології та ортопедії дитячого віку НАМН України». Адреса: м. Київ, вул. Бульварно-Кудрявська, 27; тел. (044) 486-29-73. https://orcid.org/0000-0001-8128-4196.

Видерко Роман Васильович - лікар ортопед-травматолог відділу травматології та ортопедії дитячого віку ДУ «Інститут травматології та ортопедії дитячого віку НАМН України». Адреса: м. Київ, вул. Бульварно-Кудрявська, 27; тел. (044) 486-29-73.

Зотя Андрій Володимирович - мол.н.с. відділу травматології та ортопедії дитячого віку ДУ «Інститут травматології та ортопедії дитячого віку НАМН України». Адреса: м. Київ, вул. Бульварно-Кудрявська, 27; тел. (044) 486-29-73. 


\title{
В.С. Хоменко ${ }^{1}$, В.П. Перепелиця ${ }^{1}$, І.О. Кучинський ${ }^{1}$, А.В. Сироткін ${ }^{1}$, Л.В. Хоменко ${ }^{2}$ Неоклюзивні порушення брижового кровотоку (огляд літератури)
}

\author{
${ }^{1}$ КНП «Обласна клінічна лікарня імені О.Ф. Гербачевського» Житомирської обласної ради, Україна \\ ${ }^{2}$ КП «Лікарня № 1» Житомирської міської ради, Украӥна
}

Paediatric surgery.Ukraine.2021.3(72):76-83; doi 10.15574/PS.2021.72.76

For citation: Khomenko VS, Perepelitsia VP, Kuchynskyi IO, Sirotkin AV, Khomenko LV. (2021). Nonocclusive mesenteric ischemia (literature review). Paediatric Surgery.Ukraine. 3(72):76-83; doi 10.15574/PS.2021.72.76.

Гострі порушення мезентеріального кровотоку залишаються найскладнішою патологією ургентної абдомінальної та судинної хірургії, як з точки зору діагностики, так і лікування. Поряд з типовими, загальновідомими механізмами розвитку гострих ішемічних уражень, спричинених артеріальною або венозною оклюзією, існує абсолютно інша група гострих порушень мезентеріального кровотоку - неоклюзивна мезентеріальна ішемія (НОМI). НОМІ - маловивчена та надзвичайно складна патологія з точки зору діагностики. Широкий спектр причин розвитку неоклюзивного ураження різко ускладнює діагностику та диференціацію з іншою абдомінальною патологією.

У переважній більшості вітчизняних публікацій, присвячених гострим розладам мезентеріального кровотоку, здебільшого розглядають проблеми діагностики та лікування оклюзивних типів мезентеріальної ішемії, натомість тематика неоклюзивної ішемії залишається недостатньо висвітленою. 3 огляду на те, що в половині випадків НОМІ діагностують на етапі непоправних некротичних змін кишечника, слід узагальнити основні причини та механізми розвитку НОМІ, сучасні методи діагностики та лікування.

Мета - за даними літератури проаналізувати причини, поширеність, класифікацію, діагностику й лікування неоклюзивних порушень брижового кровотоку.

На основі огляду літератури зроблено такі висновки: НОМІ асоціюється з поганим прогнозом через відсутність точних діагностичних засобів, передусім чітких біохімічних маркерів, тому пошук та розробка останніх являється пріоритетним напрямом; контрастні методи обстеження (комп'ютерна томографія, ангіографія) $\epsilon$ єдиними можливими інструментами діагностики; фармакологічна корекція являється фундаментальною та полягає в застосуванні препаратів судинорозширювальної дії системно або локально (катетер-асоційовано); важливим напрямом $є$ розроблення фармакологічних агентів, що дають змогу таргентно впливати на патогенетичні механізми розвитку НОМІ; мультидисциплінарний підхід за участю профільного фахівця, хірурга, рентгенендоваскулярного хірурга та лікаря-інтенсивіста у лікуванні пацієнта з підозрою на НОМІ становить фундамент успіху терапії; дискусійним залишається питання широкого застосування лапароскопії з огляду на інвазивність методу та складність інтерпретації виявлених змін у ранню фазу захворювання.

Автори заявляють про відсутність конфлікту інтересів.

Ключові слова: гостра мезентеріальна ішемія, неоклюзивні порушення брижового кровотоку.

\footnotetext{
Nonocclusive mesenteric ischemia (literature review)

V.S. Khomenko ${ }^{1}$, V.P. Perepelitsia ${ }^{1}$, I.O. Kuchynskyi ${ }^{1}$, A.V. Sirotkin ${ }^{2}$, L.V. Khomenko ${ }^{2}$

${ }^{1} \mathrm{ME}$ «Regional clinical hospital named after O.F. Gerbachevsky» of Zhytomyr regional Council, Ukraine

${ }^{2} P C$ «Hospital No.1» of Zhytomyr City Council, Ukraine

Non-occlusive mesenteric ischemia is a relatively rare but extremely complex pathology in terms of diagnosis. A wide range of reasons for the development of non-occlusive impression dramatically complicates the diagnosis and differentiation with other abdominal pathology. The vast majority of publications in the domestic literature on acute disorders of mesenteric blood flow, mostly address the problems of diagnosis and treatment of occlusive types of mesenteric ischemia, while the topic of non-occlusive ischemia remains insufficiently covered.

Given that in half of the cases NOMI is diagnosed at the stage of irreversible necrotic changes of the intestine - there is a real need to generalize the root causes and mechanisms of neoclustive mesenteric ischemia, modern methods of diagnosis and treatment.

Purpose - to analyze of the causes, prevalence, classification, diagnosis and treatment of non-occlusive disorders of mesenteric blood flow.
} 
This research, based on literature review, showed that acute non-occlusive mesenteric ischemia (NOMI) is associated with poor prognosis due to the lack of accurate diagnostic measures. First of all, clarity regarding biochemical markers. Therefore, the research and development of the latter is seen as a priority. Contrast methods of examination (computed tomography, angiography) are the only possible diagnostic tools. Pharmacological correction is fundamental and presupposes the use of drugs with a vasodilating effect systemically or locally (catheter-associated). An important issue is the development of pharmacological agents that allow targeted action on the pathogenetic mechanisms of the development of NOMI. A multidisciplinary approach involving a specialized doctor, a surgeon, an X-ray endovascular surgeon and an intensive care physician in the treatment of a patient with suspected NOMI is the foundation for the success of therapy. The question of the use of laparoscopy remains controversial, given the invasiveness of the method and the difficulty of interpreting the changes detected in the early phase of the disease.

No conflict of interests was declared by the authors.

Key words: acute mesenteric ischemia, non-occlusive disorders of mesenteric blood flow.

\section{Неоклюзионные нарушения брыжеечного кровотока (обзор литературы)}

В.С. Хоменко ${ }^{1}$, В.П. Перепелица ${ }^{1}$, И.А. Кучинский ${ }^{1}$, А.В. Сироткин ${ }^{2}$, Л.В. Хоменко ${ }^{2}$

${ }^{1}$ КНП «Областная клиническая больница им. А.Ф. Гербачевского» Житомирского областного совета, Украина

${ }^{2}$ КП «Больница № 1» Житомирского городского совета, Украина

Острые нарушения мезентериального кровотока несомненно остаются наиболее сложной патологией ургентной абдоминальной и сосудистой хирургии, как с точки зрения диагностики, так и лечения. Наряду с типичными, общеизвестными механизмами развития острых ишемических поражений, вызванных артериальной или венозной окклюзией, существует совершенно другая группа острых нарушений мезентериального кровотока - неоклюзионная мезентериальная ишемия (НОМИ). НОМИ - относительно редкая, но чрезвычайно сложная патология с точки зрения диагностики. Широкий спектр причин развития неоклюзионного поражения резко затрудняет диагностику и дифференциацию с другой абдоминальной патологией. Подавляющее большинство публикаций в отечественной литературе, посвященных острым расстройствам мезентериального кровотока, в основном рассматривают проблемы диагностики и лечения окклюзионных типов мезентериальной ишемии, зато тематика неоклюзионной ишемии остается недостаточно освещенной.

Учитывая то, что в половине случаев НОМИ диагностируется на этапе необратимых некротических изменений кишечника, существует реальная потребность в обобщении основных причин и механизмов развития НОМИ, современных методов диагностики и лечения.

Цель - по данным литературы проанализировать причины, распространенность, классификацию, диагностику и лечение неоклюзивних нарушений брижеечного кровотока.

На основе обзора литературы сделаны следующие выводы: НОМИ ассоциируется с плохим прогнозом из-за отсутствия точных диагностических мероприятий, прежде всего четких биохимических маркеров, поэтому поиск и разработка последних является приоритетным направлением; контрастные методы обследования (компьютерная томография, ангиография) являются единственными возможными инструментами диагностики; фармакологическая коррекция является фундаментальной и заключается в применении препаратов сосудорасширяющего действия системно или локально (катетерассоциировано); важным направлением является разработка фармакологических агентов, позволяющих таргентно воздействовать на патогенетические механизмы развития НОМИ; мультидисциплинарный подход с участием профильного специалиста, хирурга, рентгенэндоваскулярного хирурга и врачаинтенсивиста в лечении пациента с подозрением на НОМЕ является фундаментом успеха терапии; дискуссионным остается вопрос широкого применения лапароскопии, учитывая инвазивность метода и сложность интерпретации выявленных изменений в раннюю фазу заболевания.

Авторы заявляют об отсутствии конфликта интересов.

Ключевые слова: острая мезентериальная ишемия, неоклюзионные нарушения брыжеечного кровотока.

«Діагностика кишкової ішемії розпочинається зі спроможності лікаря запідозрити та розпізнати ией стан ... виявлення такого серйозного захворювання може стати діагностичною та лікувальною дилемою»

(J. Sreenarasimhaiah)

Гостра мезентеріальна ішемія є однією з найбільш драматичних ситуацій у невідкладній хірургії органів черевної порожнини. Тяжкість непоправних змін кишечника не завжди відповідає скудній клінічній симптоматиці на початку захворювання. Cokkins на початку XX ст. так охарактеризував це захворювання: діагноз неможливий, прогноз безнадійний, лікування марне. У світі відмітилася тенденція до збільшення кількості випадків госпіталізацій 3 приводу гострого порушення мезентеріального кровообігу, перевищуючи приріст цього показника з інших ургентних хірургічних нозологій, за винятком гострого панкреатиту. Відсутність специфічної симптоматики не лише ускладнює диференціацію $з$ іншими видами гострих порушень мезентеріального кровотоку, але й з іншою ургентною патологією органів черевної порожнини. Неоклюзивна мезентеріальна ішемія (НОМI) - особливий вид гостро- го порушення брижового кровотоку, що характеризується відсутністю анатомічного субстрату оклюзії в системі верхньобрижових судин і виникає внаслідок вісцеральної вазоконстрикції на тлі низького серцевого викиду [17] або опосередкований фармакологічними агентами, які викликають вісцеральний вазоспазм, що призводить до глибоких розладів трофіки кишечника.

Однією з основних причин гіподіагностики є супутня тяжка соматична патологія в такої групи хворих. Випадки НОМІ стають все більш поширеними у зв'язку зі старінням суспільства та збільшенням діалізної популяції населення [3]. Ризик розвитку НОМІ зростає з віком [10]. У половині випадків НОМІ діагностується на стадії непоправних некротичних змін кишечника.

Пріоритет відкриття НОМІ досить спірний. За даними В.С. Савельєва, у більшості публікацій відкриття цього виду мезентеріальної ішемії належить Thorek 
(1943), проте Larsen (1970) вважає, що вперше патологію описав Moulonguet у 1931 р. [1]. За даними зарубіжних джерел, НОМІ як особливий вид гострої мезентеріальної ішемії виділили в 50-х роках ХХ ст. У 1951 р. Cohen повідомив про випадок інфаркту шлунка, тонкого і товстого кишечника у хворого з тяжким «легеневим серцем», у якого не виявили мезентеріальної оклюзії. Wilson i Qualheim y 1954 р. описали «гострий геморагічний ентероколіт» у 20 пацієнтів, в яких під час секції не верифікували мезентеріальної оклюзії, із них 17 осіб мали хронічну кардіоваскулярну патологію [13]. У 1958 р. Ende вперше описав випадок НОМІ після кардіоваскулярного оперативного втручання. У 1965 р. Kligerman i Vidone опублікували огляд, в якому повідомили про 109 випадків HOMI, описаних на той час у світовій літературі. У подальшому в Європі та Америці описали чисельні випадки цієї патології [3,20].

Летальність при цій патології залишається стабільно високою і досягає 50-70\% [2], хоча в останні 20 років відмічається тенденція до зниження рівня смертності в межах 50\%. У 60-80-х роках XX ст., у зв' язку з широким застосуванням вазопресорів у кардіологічних хворих, летальність сягала 100\%. До появи сучасної інтенсивної та судинорозширювальної терапії НОМІ зустрічалася досить часто. Вазоспазм, достатній для виникнення інфаркту кишечника, може розвиватися на тлі вживання кокаїну та препаратів маткових ріжків (споринні). Серед основних фармакологічних препаратів, що найчастіше викликають розвиток НОМІ в клінічній практиці, $є$ дігоксин. Доведено, що глікозиди викликають вісцеральний вазоспазм in vitro та in vivo, крім того, можуть відігравати провокативну роль шляхом збільшення периферичного вісцерального опору. Вісцеральна вазоконстрикція відмічена шляхом внутрішньовенного введення препаратів наперстянки соматично здоровим пацієнтам і пацієнтам із серцевою недостатністю. Доведено, що припинення терапії препаратами наперстянки не поліпшує клінічного прогнозу, що передусім пов'язано з тривалою циркуляцією препарату в плазмі крові (до 7 діб) [19].

Z. Muhammad та співавт. повідомили про випадок розвитку НОМІ у хворого з цирозом печінки та без будьяких інших вагомих предикторів розвитку [11]. Oshikata та співавт. у 2013 р. описали розвиток НОМІ у хворого 3 тромбоцитопенічною пурпурою [15], а також повідомили про випадок розвитку НОМІ у 19-річної пацієнтки внаслідок передозування пропранололом [22].

Застійна серцева недостатність є найбільшим фактором ризику, що доведено дослідженнями на великій популяцї [2].

Неоклюзивна мезентеріальна ішемія при гострому панкреатиті супроводжується високим показником ле- тальності. Одним із можливих механізмів розвитку панкреонекрозу вважають обструкцію мікроциркулярного русла, спричинену вазоспазмом, гіперкоагуляцією, гіповолемією. У літературі описані поодинокі випадки HOMI при гострому панкреатиті. Існує чіткий зв'язок між тяжкістю гострого панкреатиту й частотою розвитку HOMI: останню частіше діагностують при тяжкості панкреатиту 5 балів і більше за шкалою Ranson.

Основні групи можливих причин розвитку НОMI [7]:

А. Гостре зменшення інтрамурального кровотоку:

1. Мікроангіопатії:

- холестериновий ембол;

- діабетична ангіопатія;

- ревматоїдний артрит;

- хронічне променеве ураження;

- амілоїдоз;

- системні васкуліти;

- колагенози;

- алергічний гранулематоз;

- синдром Бехчета.

2. Неоклюзивна гіпоперфузія:

- гіперкоагуляційні стани та стани, пов'язані 3 підвищеною в'язкістю крові;

- застосування оральних контрацептивів;

- істинна поліцитемія;

- серпоподібноклітинна анемія;

- гостра лейкемія;

- дефіцит антитромбіну C;

- шок;

- кровотеча;

- гіповолемія;

- епізод штучного кровообігу;

- реконструктивні втручання на черевній аорті;

- сепсис;

- гострий панкреатит;

- анафілаксія;

- синдром поліорганної недостатності;

- застійна серцева недостатність;

- портальна гіпертензія;

- фармакологічні препарати:

- дигіталіс;

- діуретики;

- катехоламіни;

- естрогени;

- нестероїдні протизапальні засоби;

- нейролептики;

- надтерапевтичні дози верапамілу.

Б. Умови, що погіриують пограничні розлади кровотоку:

1. Збільшення метаболічних потреб:

- онкопроцес;

- дивертикулярна хвороба. 
2. Зниження кровотоку внаслідок збільшення внутрішньопросвітного тиску:

- обтураційний ілеус;

- колоноскопія;

- барієва клізма.

\section{B. Idіопатична НОМI.}

\section{Проблеми класифікації}

Здебільшого гостру мезентеріальну ішемію класифікують на артеріальну оклюзію, венозну оклюзію та HOMI. P.H. MacDonald, D.J. Hurlbut i I.T. Beck натомість, поряд з артеріальною та венозною оклюзією, виділяють групу інтрамуральних васкулярних оклюзій (гіпоперфузій), до якої автори відносять неоклюзивну мезентеріальну гіпоперфузію та інтраваскулярні тромбози й емболії. Перелічені фактори призводять спочатку до розвитку негангренозних захворювань кишечника, а при прогресуванні - до гангренозних [7]. Michael G. Wilcox MD та співавт. до групи неоклюзивних причин поряд з НОМІ відносять некротичний ентероколіт новонароджених [13].

Неоклюзивні порушення становлять близько 20\% видів гострих порушень брижового кровотоку. Цей вид порушення виникає в 4-5\% хворих, які перенесли оперативне втручання на черевній аорті [12]. Загальна частота НОМІ дорівнює приблизно 1 випадок на 5000 госпіталізацій [6,13].

\section{Патогенез}

Патогенез неоклюзивної ішемії остаточно не відомий, проте здебільшого асоціюється з периферичним вісцеральним вазоспазмом на тлі низького серцевого викиду [3], що, своєю чергою, призводить до глибокої гіпоксії та некрозу кишечника. У результаті тривалої гіпоксії виникає тканинний ацидоз, який посилює ангіоспазм. Розвиток вазоспазму на рівні капілярів та прекапілярів $€$ найнебезпечнішим. Ендогенні та екзогенні вазоконстриктори, ДВЗ-синдром, реперфузійний синдром, вазоактивні препарати можуть бути окремими ланками патогенезу [19]. В умовах глибокого фізіологічного стресу ауторегуляторні механізми мезентеріального кровотоку перевантажуються нейрогуморальними агентами, такими як ангіотензин II та вазопресин. Глибокі патофізіологічні зрушення можуть зберігатися і після відновлення мікроциркуляції та ліквідації основної причини розвитку неоклюзивного порушення кровотоку. Неоклюзивні порушення однаковою мірою чинять вплив на тонкий та товстий кишечник. Експериментальні дослідження свідчать, що частоповторювані епізоди розладу мікроциркуляції при неоклюзивній ішемії спричинюють серйозніші ураження порівняно з одноразовим епізодом оклюзивного ураження.

Важливим фактором, який поглиблює кишкову ішемію, $€$ феномен судинного спазму. Чітко доведено, що оклюзивні та неоклюзивні форми мезентеріальної ішемії можуть завершитися тривалим судинним спазмом, на-

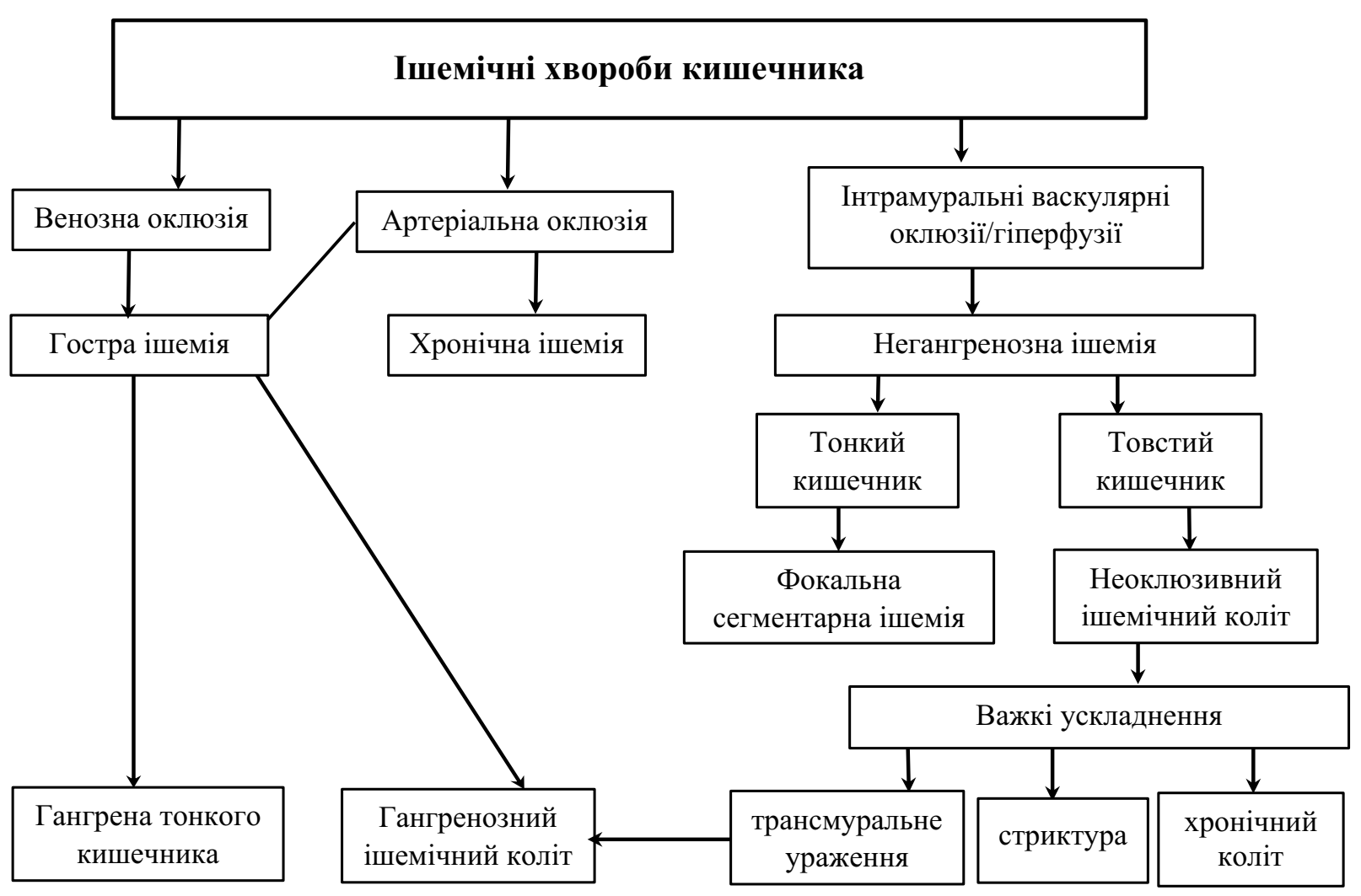

Рис. 1. Класифікація ішемічних захворювань кишечника 
віть після ліквідації органічного фактора оклюзії або гіпоперфузії. Аргументованого пояснення такому феномену немає, проте вважають, що одним із факторів, які впливають на цей стан, може бути потужний вазоконстриктор - ендотелін, що вивільняється з інтими судин при виникненні ішемії.

Розлади мікроциркуляції розпочинаються на мікроциркулярному рівні (артеріоли, прекапіляри, капіляри) з розвитком мікротромбозів в останніх. Тому тромбоз мілких вен кишкової стінки вважається гістологічним підтвердженням діагнозу. При гістологічному дослідженні артеріальний стеноз на рівні прямих артерій виявляється в більш ніж 80\% випадків, крім того, потовщення інтими прямих артерій достовірно виявляється в 94,7\% випадках.

Іншим не менш важливим фактором посилення ішемічного пошкодження являється реперфузійний синдром. На моделі тварин доведено, що ішемічне ураження після годинної ішемії і тригодинної реперфузії тяжке, ніж при чотиригодинній безперервній ішемії.

\section{НОМІ в діалізних пацієнтів}

Гемодіалізне населення - група, яка особливо схильна до розвитку НОМI [4], що передусім пояснюється діалізною гіпотензією та гіповолемією [16].

За статистикою, 7\% населення мають ознаки хронічної хвороби нирок. На V стадіїії розвитку пацієнти потребують замісної ниркової терапії, яка на сучасному етапі передбачає різні комбінаціїії методів - гемодіалізу, перитонеального діалізу або трансплантації нирки. Якщо у Фінляндії основним видом замісної терапії стала трансплантація нирки, то в Україні, де кількість подібних операцій мізерна, основним методом був, $є$ і ще протягом тривалого часу залишатиметься гемодіаліз [22]. Захворюваність на НОМІ у цій групі хворих коливається від 0,3\% до 1,9\% на рік і має тенденцію до неухильного зростання [6].

В 11 з 12 діалізних пацієнтів клінічна картина «гострого живота» пов'язана з розвитком НОMI, при цьому в 10 з 12 пацієнтів відмічається хоча б один епізод гіпотензії протягом тижня перед розвитком НОМI [23]. HOMI спричиняє 9\% смертності серед діалізної популяції. Хворі $з$ хронічною нирковою недостатністю мають ряд факторів ризику, що потенціюють розвиток неоклюзивного ураження: системний атеросклероз, низький серцевий викид, епізоди інтрадіалізної гіпотензії.

B.С. Савельєв припустив можливість розвитку НОМІ за такими механізмами [1]:

1. При неповних оклюзіях артерій.

2. Унаслідок ангіоспазму.

3. Унаслідок централізації гемодинаміки.

У більшості випадків передумовами розвитку НОМІ є:
1. Довгостроковий гемодіаліз, унаслідок якого відбувається дегідратація з гіповолемією. Після виникнення абдомінального болю заміщення об’єму саме по собі не здатне ліквідувати вазоспазм і відновити перфузію.

2. Клінічні стани, за яких здійснювались оперативні втручання на серці з використанням штучного кровообiry.

3. Застосування препаратів дигіталісу.

4. Патофізіологічні стани, що є однією з ланок поліорганної недостатності: ДВЗ-синдром, сепсис, гострий панкреатит тощо.

\section{Клінічна картина й діагностика}

Діагностика НОМІ особливо складна, оскільки більшість пацієнтів госпіталізовані до стаціонару $з$ іншою тяжкою соматичною патологією, яка переважно маскує розвиток мезентеріальної ішемії, або ж анамнестичні дані отримати неможливо через відсутність свідомості, а об'єктивне обстеження не несе необхідної клінічної інформації.

Клінічна діагностика передусім має базуватися на наявності больового синдрому у хворого з урахуванням факторів ризику першої лінії, зокрема, вік хворого від 50 років на тлі явищ застійної серцевої недостатності, застосування препаратів дигіталісу, гіповолемії / гіпотензії, септичного стану. Проте слід зауважити, що в 10-15\% випадків больовий синдром відсутній [9], а прояви здебільшого неспецифічні у вигляді нудоти, блювоти, явищ кишкової непрохідності, спінального болю, здуття живота, ректальної кровотечі тощо.

Клінічна маніфестація у хворих після кардіоваскулярних втручань проявляється в діапазоні від 4 до 9 діб, що передусім пов'язано з респіраторною підтримкою та седацією. На сьогодні не існує специфічних лабораторних тестів, спрямованих на виявлення НОМI [10,24]. Як правило, диференціювати НОМІ від інших гострих порушень мезентеріального кровотоку неможливо. Спостерігається підвищення сироваткових ензимів: амілази, лужної фосфатази, лактатдегідрогенази, креатинфосфокінази як ранніх маркерів брижової ішемії, проте їх специфічність сумнівна. Системна дегідратація в поєднанні 3 гемоконцентрацією може наштовхувати на діагностичний пошук НОМІ. Метаболічний ацидоз виникає в 50\% випадків [9].

Неоклюзивна мезентеріальна ішемія має бути включена в диференційний діагноз для пацієнтів, в яких виник різкий дифузний біль у животі на тлі застосування препаратів наперстянки. НОМІ має бути запідозрена в пацієнтів із гіпотонією або шоком, особливо кардіогенним, в яких виникає абдомінальний біль, (рівень доказовості В) та в пацієнтів з абдомінальним болем після корекції коарктації або після хірургічної реваскуляриза- 
ції з приводу ішемії кишечника, обумовленої артеріальною обструкцією [17].

\section{Інструментальна діагностика}

Неоклюзивна мезентеріальна ішемія може бути діагностована за таких умов [14]:

1. Відсутність очевидної органічної оклюзії.

2. Кишкова ішемія та некроз носить сегментарний характер.

3. Очевидний некроз при патогістологічному дослідженні.

Зазвичай НОМI діагностується завдяки використанню брижової ангіографії [19]. Ряд авторів надають абсолютну перевагу ангіографії, вважаючи її «золотим стандартом» діагностики [5,17]. Артеріографія показана пацієнтам із підозрою на НОMI, стан яких не поліпшується у відповідь на лікування (рівень доказовості В).

До ангіографічних ознак неоклюзивної ішемії кишечника належать: спазм сегментарних гілок верхньої брижової артерії, нерівномірність галуження інтестинальних гілок, спазм аркад, ослаблене наповнення інтрамуральних гілок, сповільнений потік контрасту з рефлюксом в аорту при селективному контрастуванні a.mesenterica superior [12,19]. Stefan Klotz та співавт. повідомили, що НОМІ діагностували в 64\% випадках шляхом застосування ангіографії [18]. За даними В.Г. Громи, найчастіше ангіографія при НОМI не виявляла патології: констатували брижові судини нормальної структури і прохідності [12].

Ряд авторів, з огляду на власний досвід діагностики та лікування хворих з НОМІ, методом вибору в діагностиці назвали мультиспіральну комп'ютерну томографію. Abhijeet Dhoble та співавт. вказали на специфічний радіологічний симптом мезентеріальної ішемії «Pneumatosis Intestinalis» (наявність повітря в кишковій стінці), який автори виявили при неконтрастному обстеженні хворого з НОМІ, проте цей симптом характерний для початку некрозу кишкової стінки [2].

Використання мультиспіральної комп'ютерної томографії за підозри на НОМІ сприяє поліпшенню діагностики, а отримана інформація про судинний басейн зіставна з отриманою під час ангіографії.

Роль колоноскопії обмежена оцінкою ступеня й протяжності ураження слизової оболонки. Колоноскопічне обстеження може бути корисним у прогнозуванні клінічного перебігу. Обстеження безпечне при ранніх стадіях захворювання, але потребує обережного виконання у зв'язку з посиленням ризику розвитку ішемічних уражень при інсуфляції повітря [5]. Колоноскопічними критеріями у хворих з НОМI $є$ сегментарний характер уражень із чіткою межею здорових і уражених ділянок. Проти методу свідчать такі моменти: значна частина ки- шечника (тонкий кишечник) не доступна для огляду, некроз слизової не завжди відповідає трансмуральному некрозу, існує вагомий ризик перфорації в ослаблених тканинах, можливість вірної морфологічної оцінки залежить від кваліфікації ендоскопіста.

Діагностична лапароскопія залишається інструментом диференційної діагностики. Суперечливі моменти застосування методу при оклюзивних ураженнях $є$ актуальними і для НОМI: тяжкість інтерпретації лапароскопічної картини на ранніх стадіях захворювання, неможливість пальпації брижі для оцінки пульсації, негативний вплив пневмоперитонеума на мезентеріальний кровотік. Високий внутрішньочеревний тиск може призводити до зменшення венозного повернення до серця і зниження серцевого викиду, що особливо принципово при НОМІ. Проте в ряді досліджень виявили, що лапароскопія може бути можливим і безпечним хірургічним підходом для ведення пацієнтів із HOMI, при цьому не збільшуючи захворюваність, зменшуючи смертність та уникаючи нетерапевтичних лапаротомій [28].

Ультразвукова діагностика з використанням доплердатчиків має доказову базу й певні переваги, здебільшого для діагностики хронічної мезентеріальної ішемії.

\section{Лікування}

Лікування хворих із верифікованою НОМІ передбачає:

1. Ліквідацію (компенсація) предикторів розвитку.

2. Призначення препаратів, які поліпшують вісцеральний кровотік.

3. Лапаротомію в разі гангренозних ускладнень.

Найголовнішим кроком при НОМІ $є$ лікування шоку, який лежить в основі цього стану (рівень доказовості С). Черезкатетерне введення препаратів судинорозширювальної дії показане хворим, в яких НОМІ виникла внаслідок застосування препаратів маткових ріжків (споринні) і кокаїну (рівень доказовості В). Через відсутність будь-яких контрольних досліджень не можна чітко стверджувати, що поліпшення в пацієнтів виникає в результаті локального чи системного застосування вазодилататорів [17].

На відміну від оклюзивних типів порушення мезентеріального кровотоку, фармакологічна корекція при HOMI $€$ першочерговою. Селективне катетер-асоційоване введення вазодилататорів $€$ пріоритетним. До основних вазодилататорів, застосовуваних у клінічній практиці, належать: папаверин, толазолін (альфаадреноблокатор), глюкагон, нітрогліцерин, нітропрусид, простагландин Е, феноксибензамін [5].

Найбільший клінічний досвід застосування має папаверин (Yaron Sternbach). 


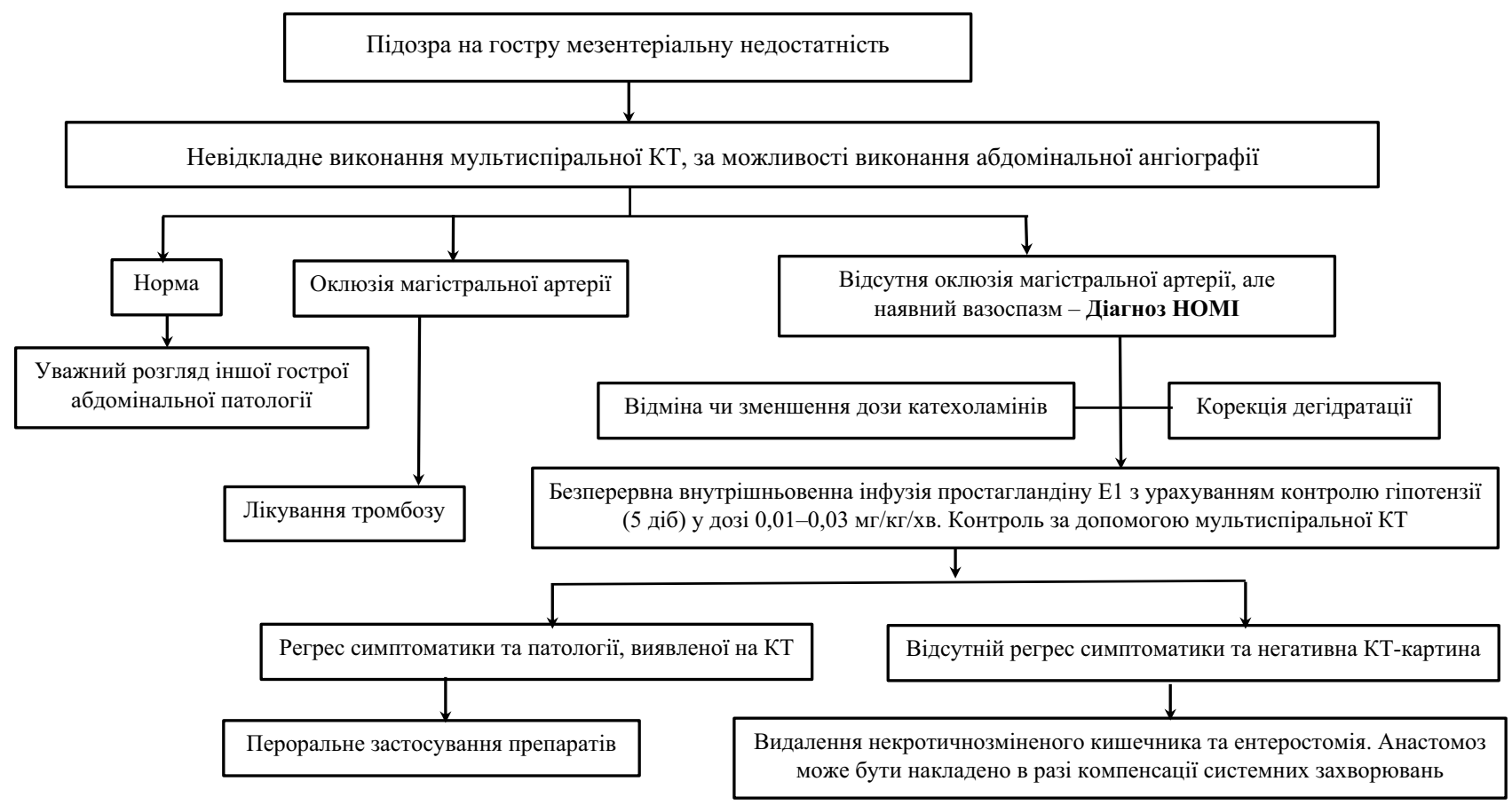

Рис. 2. Діагностично-лікувальний алгоритм HOMI (Akira Mitsuyoshi et al.) [3]

У 1977 p. Boley та співавт. показали, що персистуюча мезентеріальна вазоконстрикція може бути ліквідована шляхом селективної інфузії папаверину в a.mesenterica superior, при цьому досягається $60 \%$ виживання пацієнтів [18].

Селективне введення препарату в a.mesenterica superior забезпечують у дозі 60 мг із подальшим ангіографічним контролем. При встановленому регресі вазоконстрикції подальшу безперервну інфузію продовжують у дозі 30-60 мг/год. До потенційних негативних ефектів папаверину належить розвиток серцевих аритмій, гіпотензії та рефлекторної тахікардії.

Толазолін (альфа-адреноблокатор) можна клінічно застосовувати в дозі 25 мг болюсно, з подальшою неперервною інфузією 10-25 мг/год.

Простагландин Е1 має антиагрегантну, судинорозширювальну, ангіопротекторну дію. Розширює артерії, артеріоли і розслаблює сфінктери прекапілярів, посилює колатеральний кровотік. Впливає на гемокоагуляцію, зменшує адгезію й агрегацію тромбоцитів, підвищує пластичність еритроцитів, підвищує фібринолітичну активність крові. На системному рівні діє як вазодилататор. За даними Akira Mitsuyoshi та співавт., при верифікованій неоклюзивній ішемії препарат вводять внутрішньовенно в дозі 0,01-0,03 мг/кг/хв [3]. У середньому тривалість лікування становить 4-5 діб. Stöckmann та співавт. повідомляють про застосування простагландину Е2 у дозі 60 мг/добу протягом 3 діб у лікуванні НОМI, при цьому 8 з 9 хворих вдалося зберегти життя [25].

У зарубіжних джерелах наявні повідомлення про доцільність застосування Цилостазолу - селективного ін- гібітору фосфодієстерази 3-го типу. Механізм дії препарату спрямований на збільшення концентрації цАМФ, останнє призводить до підвищення концентрації активної форми протеїнкінази А, яка безпосередньо інгібує агрегацію тромбоцитів і сприяє розширенню судин [8].

Лапаротомія і резекція нежиттєздатної кишки показана хворим, в яких зберігається клінічна симптоматика, незважаючи на консервативну терапію (рівень доказовості В). Роль лапаротомії обмежується діагностичною метою і видаленням некротизованих ділянок кишечника. Смертність серед хворих із НОМІ після ургентної лапаротомії може сягати 66\%. Рішення про хірургічне втручання має грунтуватися на наявності перитоніту, перфорації або загального погіршення стану пацієнта [26].

Отже, на основі огляду літератури можна зробити такі висновки:

- НОМІ асоціюється з поганим прогнозом через відсутність точних діагностичних засобів, насамперед чітких біохімічних маркерів, тому пошук і розробка останніх $€$ пріоритетним напрямом;

- контрастні методи обстеження (комп'ютерна томографія, ангіографія) є єдиними можливими інструментами діагностики;

- фармакологічна корекція являється фундаментальною і полягає в застосуванні препаратів судинорозширювальної дії системно або локально (катетер-асоційовано);

- важливим напрямом $€$ розроблення фармакологічних агентів, що дають змогу таргентно впливати на патогенетичні механізми розвитку НОMI; 
- мультидисциплінарний підхід за участю профільного фахівця, хірурга, рентгенендоваскулярного хірурга та лікаря-інтенсивіста у лікуванні пацієнта з підозрою на НОМІ становить фундамент успіху терапії;

- дискусійним залишається питання широкого застосування лапароскопії з огляду на інвазивність методу і складність інтерпретації виявлених змін у ранню фазу захворювання.

Автори заявляють про відсутність конфлікту інmересів.

\section{References/Лiтература}

1. Arakelyan VS, Barbarash OL, Bolotova EV, Karpenko AA, Kozyirev OA, Samorodskaya IV, Troitskiy AV. (2010). Natsyonalnie rekomendatsyy po vedenyiu patsyentov s sosudystoi arteryalnoi patolohyei (Rossyiskyi Sohlasytelnii dokument). Moskva: 208-210. [Аракелян ВС, Барбараш ОЛ, Болотова ЕВ, Карпенко АА, Козырев ОА, Самородская ИВ, Троицкий АВ. (2010). Национальные рекомендации по ведению пациентов с сосудистой артериальной патологией (Российский Согласительный документ). Москва: 208-210].

2. Archodovassilis F. (2007). Nonocclusive mesenteric ischemia: a lethal cjmplication in peritoneal dialysis patients. Perit Dial Int. 27: 136-141.

3. Auxiliadora-Martins M. (2010). Fulminant Nonocclusive Mesenteric Ischemia Just after Hip Arthroplasty. Case Reports in Medicine: 4.

4. Bala M, Kashuk J, Moore EE, Kluger Y, Biffl W, Gomes CA, Ben-Ishay O, Rubinstein C, Balogh ZJ, Civil I, Coccolini F, Leppaniemi A, Peitzman A, Ansaloni L, Sugrue M, Sartelli M, Di Saverio S, Fraga GP, Catena F. (2017). Acute mesenteric ischemia: guidelines of the World Society of Emergency Surgery. World J Emerg Surg. 12: 38.

5. Bawany MZ. (2010). The Unusual Suspect: A Case of Non-occlusive Mesenteric Ischemia in a Patient With Cirrhosis. Gastroenterology Research. 3 (5): 232-233.

6. Bourcier S, Klug J, Nguyen LS. (2021). Non-occlusive mesenteric ischemia: Diagnostic challenges and perspectives in the era of artificial intelligence. World journal of gastroenterology. 27 (26): 4088-4103.

7. Chehab BM. (2008). Non-Occlusive Mesenteric Ischemia. Kansas Journal of Medicine: $49-52$.

8. Cocorullo G, Mirabella A, Falco N, Fontana T, Tutino R, Licari L, Salamone G, Scerrino G, Gulotta G. (2017). An investigation of bedside laparoscopy in the ICU for cases of non-occlusive mesenteric ischemia. World J Emerg Surg. 18 (12): 4.

9. Dhoble A. (2008). Non-occlusive mesenteric ischemia leading to 'pneumatosis intestinalis': a series unfortunate hemodynamic events. Cases Journal. 1:60

10. Han SY et al. (2000). Nonocclusive Mesenteric Ischemia in a Patient on Maintenance Hemodialysis. The Korean Journal of Internal Medicine. $15(1): 81-84$

11. Hroma VH. (2011). Mistse ta rol neokliuzyvnoi mezenterialnoi ishemii v strukturi hostrykh porushen krovotoku v baseinakh bry- zhovykh sudyn. Eksperymentalna i klinichna medytsyna. 4 (53): 139-142. [Грома ВГ. (2011). Місце та роль неоклюзивної мезентеріальної ішемії в структурі гострих порушень кровотоку в басейнах брижових судин. Експериментальна і клінічна медицина. 4 (53): 139-142].

12. John A.S. (2000). Nonocclusive Mesenteric Infarction in Hemodialysis Patients. J Am Coll Surg. 190: 84-88. doi: 10.1016/s10727515(99)00226-4.

13. Kayahan H. (2008). A case of angiographically verified non-occlusive mesentery ischemia induced by digitalis. Turk J Gastroenterol. 19 (2): 125-128.

14. Klotz S. (2001). Diagnosis and Treatment of Nonocclusive Mesenteric Ischemia After Open Heart Surgery. Ann Thorac Surg. 72: $1583-1586$.

15. Maruyama Y. (2008). Nonocclusive Mesenteric Ischemia after Aortic Surgery in a Hemodialysis Patient. Ann Thorac Cardiovasc Surg. 14: 2

16. Mitsuyoshi A. (2007, Aug). Survival in Nonocclusive Mesenteric Ischemia Early Diagnosis by Multidetector Row Computed Tomography and Early Treatment With Continuous Intravenous High-dose Prostaglandin E1. Annals of Surgery. 246: 2.

17. Oldenburg AW. (2004). Acute Mesenteric Ischemia. A Clinical Review. Arch Intern Med. 164: 1054-1062.

18. Oshikata. (2013). An adult patient with Henoch-Schцnlein purpura and non-occlusive mesenteric ischemia. BMC Research Notes. 6: 26.

19. Pettei MJ. (1990). Nonocclusive Mesenteric Ischemia Associated with Propranolol Overdose. Journal of Pediatric Gastroenterology \& Nutrition. 10: 544-547.

20. Powell A, Armstrong P. (2014). Plasma biomarkers for early diagnosis of acuteintestinal ischemia. Semin Vasc Surg. 27: 170-175.

21. Savelev BC, Spyrydonov YV. (1979). Ostrie narushenyia mezenteryalnoho krovoobrashchenyia. M: Medytsyna: 232. [Савельев BC, Спиридонов ИВ. (1979). Острые нарушения мезентериального кровообращения. М: Медицина: 232] .

22. Stockmann H, Roblick UJ, Kluge N. (2000). Diagnosis and therapy of non-occlusive mesenteric ischemia. Zentralbl Chir. 125: 144-151.

23. Sudharshana Murthy KA. (2012, Jan-Mar). Non-occlusive mesenteric ischemia and the role of cilostazol in its management. J Pharmacol Pharmacother. 3 (1): 68-70.

24. Takeuchi N. (2012). Non-Occlusive Mesenteric Ischemia During the Course of Heart Failure. J Clin Case Rep. 2: 15.

25. Thomson ABR, Shaffer EA. (2000). First principles of gastroenterology. The Canadian Association of Gastroenterology. Ischemic Disease of the Intestine. Fifth edition: 288 .

26. Trompeter M. (2002). Non-occlusive mesenteric ischemia: ethiology, diagnosis, and interventional therapy. Eur radiol. 12: 1179-1187.

27. Wilcox MG. (1995). Current theories of pathogenesis and treatment of nonocclusive mesenteric ischemia. Digestive diseases and sciences. 40 (4): 709-716.

28. Zeier M, Wiesel M, Rambausek M, Ritz E. (1995). Non-occlusive mesenteric infarction in dialysis patients: the importance of prevention and early intervention. Nephrol Dial Transplant. 10 (6): 771-773.

\section{Відомості про авторів:}

Хоменко Віталій Станіславович - лікар-хірург хірургічного відділення КНП «Обласна клінічна лікарня імені О.Ф. Гербачевського» Житомирської обласної ради. Адреса: м. Житомир, вул. Червоного Хреста, 3; тел. (0412) 43-17-96.

Перепелиия Віктор Петрович - зав. хірургічним відділенням КНП «Обласна клінічна лікарня імені О.Ф. Гербачевського» Житомирської обласної ради. Адреса: м. Житомир, вул. Червоного Хреста, 3; тел. (0412) 43-17-96.

Кучинсвкий Ілля Олександрович лікар-хірург (інтерн) хірургічного відділення КНП «Обласна клінічна лікарня імені О.Ф. Гербачевського» Житомирської обласної ради. Адреса: м. Житомир, вул. Червоного Хреста, 3; тел. (0412) 43-17-96.

Сироткін Андрій Вікторович лікар-хірург хірургічного відділення КНП «Обласна клінічна лікарня імені О.Ф. Гербачевського» Житомирської обласної ради; Адреса: м. Житомир вул. Червоного Хреста, 3; тел. (0412) 43-17-96.

Хоменко Любов Валеріївна - лікар-анестезіолог відділення анестезіологї з ліжками для інтенсивної терапії КП «Лікарня № 1» Житомирської міської ради. Адреса: м. Житомир, вул. Велика Бердичівська, 70.

Стаття надійшла до редакції 17.06.2020 р., прийнята до друку 08.09.2021 p. 


\title{
О.Б. Боднар ${ }^{1}$, Б.М. Боднар ${ }^{1}$, А.В. Іринчин ${ }^{2}$, I.I. Пастернак ${ }^{2}$, Р.Ю. Рандюк ${ }^{1}$ \\ Повне подвоєння уретри у хлопчика з епіспадією
}

\author{
${ }^{1}$ Буковинський державний медичний університет, м. Чернівиі, Україна \\ ${ }^{2}$ КНП «Міська дитяча клінічна лікарня» Чернівецької міської ради, Украйна
}

Paediatric surgery.Ukraine.2021.3(72):84-88; doi 10.15574/PS.2021.72.84

For citation: Bodnar OB, Bodnar BM, Irinchin AV, Pasternak II, Randiuk RYu. (2021). Complete duplication of the urethra in a boy with epispadias. Paediatric Surgery. Ukraine. 3(72):84-88; doi 10.15574/PS.2021.72.84.

Подвоєння уретри - це рідкісна аномалія, що може зустрічатися з іншими вадами урогенітального тракту. Ішемія в ембріогенезі, дефект розвитку урогенітального синусу, аномалія Мюллерових протоків та неповне мезодермальне зрощення $є$ патофізіологічними механізмами виникнення патології. Діагностика подвоєння уретри базується на клінічному огляді, анамнезі захворювання, даних уретрографії та магнітнорезонансної томографії. Під час операції видалення додаткової уретри слід враховувати класифікацію вади за Effmann та Leibowitz, розташування уретр і простати, відстань між устями уретр.

Клінічний випадок. Наведено клінічний випадок хлопчика з епіспадією І ступеня та повним подвоєнням уретри. Сечопуск був збережений та здійснювався з дорзально-епіспадованої уретри, вентральний сечівник був облітерований у дистальній ділянці. За даними магнітно-резонансної томографії виявлена подвоєна уретра, дорзальна - відходила від передніх відділів стінки міхура, прямувала по дорзальній поверхні під дорзальним судинно-нервовим пучком, вище кавенозних тіл; отвір на рівні верхньої поверхні голівки. Дистальна / вентральна уретра відходила від задніх відділів нижньої стінки міхура, прямувала типово донизу через зародок простати, повертала вперед між ніжками кавернозних тіл та мала типове розташування, крім рівня голівки, де відмічався вигин та злиття ії 3 дорзальною уретрою, що відкривалися єдиним отвором.

Дитині виконано операцію - висічення додаткової уретральної трубки. Під час огляду дитини за 6 місяців після оперативного втручання: сечопуск однією цівкою з вентральної уретри на верхівці голівки статевого члена, вільно пропускає катетер Нелатона № 10, сечу утримує, скарг не має. Заплановано наступний етап операції (пластику статевого члена) за 1 рік після попереднього.

Висновки. При епіспадії можлива природжена вада - повне подвоєння уретри з облітерацією вентрального сечівника на верхівці голівки, що може не визначатися під час підготовки до операції з приводу епіспадії. Подвоєння уретри у хлопчиків потребує проведення магнітно-резонансної томографії для чіткішої орієнтації в анатомії вади та визначення тактики подальшого хірургічного лікування.

Дослідження виконано відповідно до принципів Гельсінської декларації. На проведення дослідження отримано інформовану згоду батьків хлопчика.

Автори заявляють про відсутність конфлікту інтересів.

Ключові слова: повне подвоєння уретри, хірургічне лікування, діти.

\section{Complete duplication of the urethra in a boy with epispadias}

\section{O.B. Bodnar', B.M. Bodnar', A.V. Irinchin' ${ }^{2}$, I.I. Pasternak ${ }^{2}$, R.Yu. Randiuk ${ }^{1}$}

${ }^{1}$ Bukovinian State Medical University, Chernivtsy, Ukraine

${ }^{2} \mathrm{MME}$ «Children's clinical city hospital», Chernivtsy, Ukraine

Duplication of the urethra is a rare abnormality that can occur with other urogenital tract congenital pathologies. Ischemia at embryogenesis, urogenital sinus defect, Muller's duct anomaly and incomplete mesodermal fusion are the pathophysiological mechanisms of the pathology onset. Duplication of the urethra diagnostics is based on clinical examination, disease anamnesis, urethrography and magnetic resonance imaging. It is nessessary to consider Effmann and Leibowitz classification, urethras and prostate location and urethral orifice distance on operation of additional urethra removing.

Clinical case. Presenting a clinical case of a boy with grade l epispadias and complete duplication of the urethra. Urination was maintained and was performed from the dorsal-epispadic urethra, the ventral urethra was obliterated in the distal region. According to the data of magnetic resonance imaging: double urethra is traced, dorsal - comes out from the anterior parts of the bladder wall, continues along the dorsal surface under the dorsal neurovascular bundle, above the cavernous bodies. The urethra opening is traced at the level of the upper surface of the head of the penis. The distal / ventral urethra comes out from the posterior parts of the lower bladder wall, typically continues down through the prostate embryo, rotated forward between of the corporas cavernosas stipes, and had a typical location with except for the level of the penis head, where it bends and merges with the dorsal urethra, which opens with a single opening. 
The surgery of excision of an additional urethra on child was performed. During the examination of the child of 6 months after surgery: urination with one stream from the ventral urethra at the apex of the head of the penis, stream freely passes the Nelaton catheter No. 10, child holds urine, there was no complaints. Performing of the next stage of the operation (penis plastic surgery) is planned after 1 year of the previous stage.

Conclusions. In cases of epispadias is possible a congenital defect - a complete douplication of the urethra with the ventral urethra obliteration at the top of the head, which may not be determined in epispadias surgery preparation. Doubling of the urethra in boys requires magnetic resonance imaging for a better orientation in the defect anatomy and to determine the tactics of further surgical treatment.

The research was carried out in accordance with the principles of the Helsinki declaration. The informed consent of the patient was obtained for conducting the studies. No conflict of interest was declared by the authors.

Key words: complete duplication of the urethra, surgical treatment, children.

\section{Полное удвоение уретры у мальчика с эписпадией}

\section{О.Б. Боднар ${ }^{1}$, Б.Н. Боднар ${ }^{1}$, А.В. Иринчин ${ }^{2}$, И.И. Пастернак ${ }^{2}$, Р.Ю. Рандюк ${ }^{1}$}

${ }^{1}$ Буковинский государственный медицинский университет, г. Черновцы, Украина

${ }^{2}$ КНП «Городская детская клиническая больница» Черновицкого городского совета, Украина

Удвоение уретры - это редкая аномалия, которая может встречаться с другими пороками урогенитального тракта. Ишемия в эмбриогенезе, дефект развития урогенитального синуса, аномалия Мюллеровых протоков и неполное мезодермальное сращение являются патофизиологическими механизмами возникновения патологии. Диагностика удвоения уретры базируется на клиническом осмотре, анамнезе заболевания, данных уретрографии и магнитно-резонансной томографии. При операции удаления дополнительной уретры необходимо учитывать классификацию пороков по Effmann $и$ Leibowitz, расположение уретр и простаты, расстояние между устьями уретры.

Клинический случай. Представлен клинический случай мальчика с эписпадией I степени и полным удвоением уретры. Мочеиспускание было сохранено и осуществлялось с дорзально-эписпадированной уретры, вентральный мочеиспускательный канал был облитерированный в дистальной области. По данным магнитно-резонансной томографии отслеживалась удвоенная уретра, дорзальная - отходила от передних отделов стенки пузыря, направлялась по дорзальной поверхности под дорзальным сосудисто-нервным пучком, выше кавенозних тел; отверстие- на уровне верхней поверхности головки. Дистальная / вентральная уретра отходила от задних отделов нижней стенки пузыря, направлялась типично вниз через зародыш простаты, поворачивала вперед между ножками кавернозных тел и имела типичное расположение, кроме уровня головки, где отмечался изгиб и слияние ее с дорзальной уретрой, которые открывались единственным отверстием.

Мальчику выполнена операция - иссечение дополнительной уретральной трубки. При осмотре ребенка через 6 месяцев после оперативного вмешательства: мочеиспускание одной струйкой с вентральной уретры на верхушке головки полового члена, свободно пропускает катетер Нелатона № 10, мочу удерживает, жалоб нет. Запланирован следующий этап операции (пластика полового члена) через 1 год после предыдущего.

Выводы. При эписпадии возможен врожденный порок - полное удвоение уретры с облитерацией вентрального мочеиспускательного канала на верхушке головки, что может не определяться при подготовке к операции по поводу эписпадии.

Удвоение уретры у мальчиков требует проведения магнитно-резонансной томографии для более четкой ориентации в анатомии порока и определения тактики дальнейшего хирургического лечения.

Исследование выполнено в соответствии с принципами Хельсинкской декларации. На проведение исследований получено информированное согласие родителей мальчика.

Авторы заявляют об отсутствии конфликта интересов.

Ключевые слова: полное удвоение уретры, хирургическое лечение, дети.

\section{Вступ}

Подвоєння уретри належить до рідкісних природжених вад розвитку сечостатевої системи хлопчиків. Для пояснення виникнення патології запропоновано деякі ембріологічні теорії: неповного мезодермального зрощення, аномалія Мюллерових протоків, ішемія в ембріогенезі та дефект розвитку урогенітального синусу [3].

Епіспадія - це рідкісна аномалія, при якій зовнішній отвір сечівника розташований на спинці статевого члена (по дорзальній поверхні). Замість розвитку по краніальному краю клоакальної мембрани, статевий горбок у разі виникнення епіспадії формується в ділянці сечопрямокишкової перетинки. Отже, частина клоакальної мембрани розміщується краніально від статевого горбка, і якщо вона розвивається, то вічко сечостатевої пазухи розташовується на краніальному боці статевого члена. У разі епіспадії без екстрофії ця вада формується як ізольований дефект [4].

Діагностика подвоєння уретри базується на клінічному огляді й анамнезі захворювання (сечопуск подвійним струменем, підтікання сечі з додаткової уретри), а також на даних уретрографії [5].

Найбільш прийнятною для клініки, на наш погляд, $€$ класифікація подвоєння уретри за Effmann та Leibowitz (рис. 1).

При подвоєнні уретри урологічна тактика індивідуальна і залежить від анатомо-морфологічних особливостей вади.

\section{Клінічний випадок}

У КНП «Міська дитяча клінічна лікарня» Чернівецької міської ради звернувся хлопчик віком 7 років з ожирінням I ступеня, скаргами на наявність сечівника по дорзальній поверхні статевого члена, дорзальним розщепленням статевого члена, надмірної шкіряної плоті по вентральній поверхні, дорзальним викривленням статевого члена. Під час зовнішнього огляду виявлено уретру, розщеплену в межах голівки статевого члена, зовнішній отвір її розташований на рівні вінцевої борозни. При сечопуску сеча виділялася одним струмком із дорзально розташованої епіспадичної 


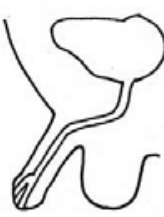

IA

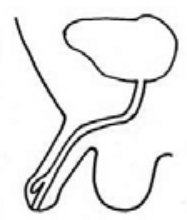

IB

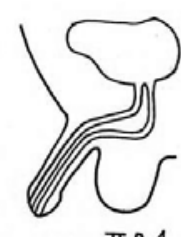

IIA1

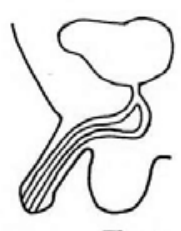

IIA 2

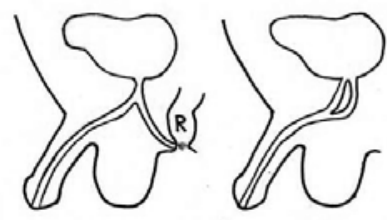

II A2 "YType"
II $\mathrm{B}$

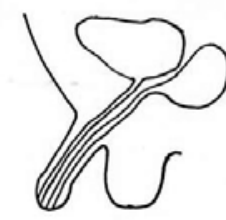

III
Рис. 1. Класифікація подвоєння уретри за Effmann тa Leibowitz [1].

уретри, спрямованої вертикально доверху, перпендикулярно осі статевого члена. За даними мікційної цистоуретрографії визначено дорзальну уретру із сечопуском однією цівкою. За результатами ультразвукового дослідження нирок, сечового міхура та екскреторної урографії патології не виявлено. Лабораторні дослідження - у межах вікової норми. У дитини констатовано епіспадію I ступеня (згідно з додатком до наказу МОЗ України від 29.12.2003 № 624 щодо протоколів лікування епіспадії в дитячій урологіï) [2].

Дослідження виконано відповідно до принципів Гельсінської декларації. На проведення дослідження отримано інформовану згоду батьків хлопчика.

Вирішено провести оперативне лікування з приводу I ступеня епіспадії. Під час оперативного втручання в дорзальну уретру встановлено катетер Нелатона № 10. У ході операції вирішено наповнити сечовий міхур. Після наповнення сечового міхура (до 300 мл $\mathrm{NaCl}$ 0,9\%) констатовано «випинання» по вентральній поверхні статевого члена. За допомогою подальшої інтраопераційної ревізії виявлено додаткову уретру по вентральній поверхні статевого члена, облітеровану на верхівці голівки, за наявності дорзальної епіспадичної уретри. Проведено висічення дорзальної хорди та вирівнювання статевого члена (підтверджено шляхом штучної ерекціі). Виконано «трикутне» розсічення дистально-облітерованого відділу вентральної уретри 3 накладанням швів PDS 6/0 і заведення катетера Фолея № 10 (рис. 2).

На цьому операцію завершено у зв'язку з необхідністю подальших досліджень з приводу подвоєння уретри. Післяопераційний період перебігав добре, рани загоїлися первинним натягом.

Під час огляду дитини за 1 рік після операції 8 років хлопчику) виявлено вирівнювання статевого члена, розщеплення голівки. Сечопуск подвій- ний, хоча, періодично, однострумовий з дорзальної або вентральної уретри. Утримання сечі - у двох уретрах. За даними мікційної цистоуретрографії: сечовий міхур округлої форми, при сечопуску визначено дві уретри, розташовані одна над одною. При проведенні уретрального катетера № $10 \mathrm{Ch}$ дорзальна трубка розташована безпосередньо під шкірою, по передній поверхні та позбавлена губчатої тканини. За результатами ультразвукового дослідження: нирки в типовому місці, контури рівні, лоханки не розширені.

У зв'язку зі складністю патології хлопчику проведено магнітно-резонансну томографію (Siemens MAGNETOM Aera, 1,5 Тл): сечовий міхур помірно наповнений, контури чіткі, стінки рівномірні. Візуалізуються 2 устя уретри (подвоєної), розміщені по нижній стінці один за одним, на відстані 6 мм. Слизова оболонка в ділянці устя уретри помірно потовщена.

Простата та сфінктерний апарат: складається враження подвоєння сфінктерів, але простата на етапах розвитку простежується лише навколо «задньої» (вентральної) уретри. Зачатки сім'яних міхурців розміщені типово, підходять до вищевказаного зачатку простати.

Статевий член: невеликих розмірів, загальна довжина разом з коренем становить 9,3 cм, зовнішня частина розташована між складками шкіри, довжина до 4,7 см.

Спостерігаються післяопераційні рубцеві зміни та вкраплення гемосидерину / шовного матеріалу в м'яких тканинах лонно-пахової ділянки по дорзальній поверхні статевого члена та в його структурі.

Простежується подвоєна уретра, дорзальна відходить від передніх відділів стінки міхура, прямує по дорзальній поверхні під дорзальним судинно-нервовим пучком, вище кавенозних тіл; отвір на рівні верхньої поверхні голівки. Дистальна / вентральна уретра відходить від задніх відділів нижньої стінки міхура, прямує типово донизу через зародок простати та типової конфігурації бульбоуретральні залози, повертає вперед між ніжками кавернозних тіл та має типове розташування, крім рівня голівки, де відмічається вигин та злиття її 3 дорзальною уретрою, що відкриваються єдиним отвором (рис. 3).

Калитка розвинена симетрично, ліве яєчко типової конфігурації та розташування. Праве яєчко має підвищене стояння в пахових відділах на виході з пахового каналу, звичайних розмірів і структури. Сечоводи на видимому рівні не розширені. 


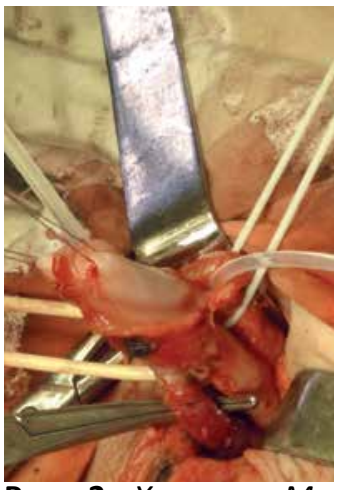

Рис. 2. Хлопчик М., 7 років. Статевий член з подвоєною уретрою. Уретри катетеризовані (1 - дорзальна уретра, 2 - вентральна уретра)

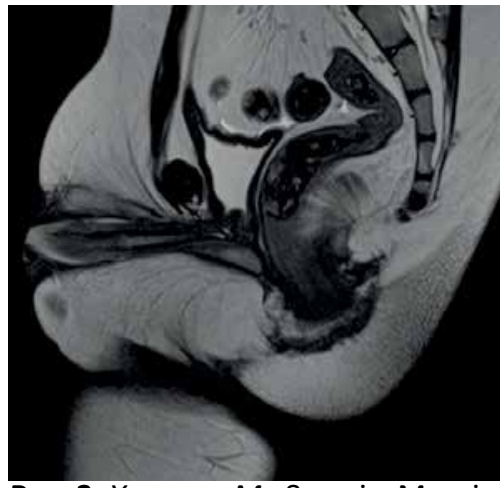

Рис. 3. Хлопчик М., 8 років. Магнітно-резонансна томографія системою «Siemens MAGNETOM Aera» (1,5 Тл). 1 - дорзальна епіспадична уретра, 2 - вентральна уретра

Вільного газу та рідини в черевній порожнині не визначається. Очеревина - без видимих потовщень. Збільшених і патологічно змінених абдомінальних лімфатичних вузлів не виявлено. Черевна стінка - без особливостей. Магістральні судини без особливостей. Вогнищевих змін та об'ємних процесів кісток на рівні сканування не визначено. Діагноз «Подвоєння уретри. Епіспадія І ступеня».

Дитині виконано операцію: висічення додаткової уретральної трубки. У дорзальну уретру та вентральну уретру встановлено катетери Фолея № 10 . Розрізи проведено по передній поверхні статевого члена. Гострим шляхом виділено дорзальну уретральну трубку в дистальному відділі від вентральної уретри та на протязі кавернозних тіл зі збереженням судин до лона, максимально до лонного з'єднання; проксимально - прошита, перев'язана, пересічена та видалена. Під час оперативного втручання пересічено зв'язки, що підтримують статевий член, зміщений дещо донизу з його подовженням (рис. 4). Післяопераційний період перебігав без ускладнень. Катетер з вентральної уретри видалено на 7-му добу. Рана загоїлася первинним натягом. Під час огляду дитини за 6 місяців після оперативного втручання: сечопуск однією цівкою з вентральної уретри на верхівці голівки статевого члена, вільно пропускає катетер № 10, сечу утримує, скарг не має. При мікційній цистоуретрографії: сечовий міхур та уретра - без патологічних змін. Оскільки виявлено розщеплення голівки статевого члена, то заплановано провести наступний етап операції (пластику статевого члена) за 1 рік після попереднього.

\section{Обговорення}

У зазначеному випадку виявлено повне подвоєння уретри у хлопчика з епіспадією І ступеня, що ви-

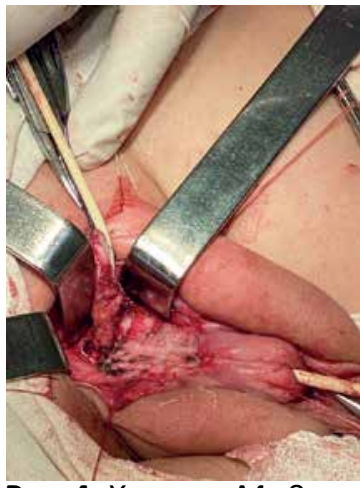

Рис. 4. Хлопчик М., 8 років. Виділена додаткова дорзальна уретральна трубка. Вентральна та дорзальна уретри катетеризовані

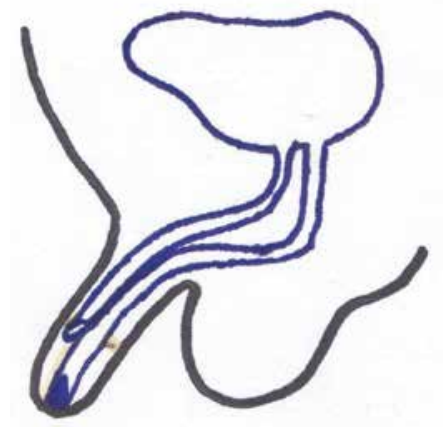

Рис. 5. Хлопчик М., 7 років. Схематичне зображення повного подвоєння уретри при епіспадії І ступеня. 1-дорзальна епіспадична уретра; 2 - вентральна, дистально облітерована уретра значено інтраопераційно. Згідно з класифікацією Effmann та Leibowitz, це II A 1 ступінь, з тією особливістю, що відмічено злиття уретри в дистальному відділі, сечопуск із дорзальної епіспадованої уретри та облітерацію вентральної уретри (рис. 5).

На думку авторів, у разі підозри на подвоєння уретри вкрай необхідним методом дослідження $€$ магнітно-резонансна томографія, яка дає змогу обрати тактику хірургічного лікування.

Вищезазначений клінічний випадок наведено у зв’язку з рідкістю вади.

\section{Висновки}

При епіспадії можлива природжена вада - повне подвоєння уретри з облітерацією вентрального сечівника на верхівці голівки, що може не визначатися під час підготовки до операції з приводу епіспадії.

Подвоєння уретри у хлопчиків потребує магнітно-резонансної томографії для чіткішої орієнтації в анатомії вади та визначення тактики подальшого хірургічного лікування.

У разі видалення додаткової уретри хірургічним шляхом слід враховувати класифікацію вади за Effmann та Leibowitz, відношення уретр до простати і відстань між устями уретр.

Автори заявляють про відсутність конфлікту iнmepeciв.

References/Лiтература

1. Bakkaly AE, Lafia T, Bouljrouf J, Rami M, Belkacem R et al. (2017). Urethral Duplication in Male Children's: Report of Four Cases. Open Access J Trans Med Res. 1 (4): 22.

2. Ministry of Health. (2003). Appendix to the order of the Ministry of Health № 624 dated 29.12.2003. [MO3. (2003). Додаток до наказу MO3 № 624 від 29.12.2003]. URL: https://zakon.rada. gov.ua/rada/show/v0624282-03\#Text.

3. Roshanzamir F, Mirshemirani A, Ghoroubi J, Mahdavi A, Mohajerzadeh L, Sarafi M. (2016). Complete Urethral 
Duplication in Children: A Case Report. Iranian journal of pediatrics. 26 (2): e3620.

4. Sadler TV. (2001). Medical embryology according to Langman. [Садлер ТВ. (2001). Медична ембріологія за Лангманом].

5. Staroverov OV, Kazachkov SA, Shuvaev AV, Demidov AA, Babanin IL, Suvorova VN. (2012). Complete doubling of the urethra in a patient with epispadias. Russian Journal of Pediatric Surgery, Anesthesiology and Intensive Care. 2 (2): 54-57. [Староверов ОВ, Казачков СА, Шуваев АВ, Демидов АА, Бабанин ИЛ, Суворова ВН. (2012). Полное удвоение уретры у больного с эписпадией. Российский вестник детской хирургии, анестезиологии и реаниматологии. 2 (2): 54-57].

\section{Відомості про авторів:}

Боднар Олег Борисович - д.мед.н., проф., зав. каф. дитячої хірургї та отоларингологї Буковинського Дму. Адреса: м. Чернівиі, вул. Буковинська, 4; тел.: (0372) 53-84-56. https://orcid.org/0000-0002-4390-3336.

Боднар Борис Миколайович - д.мед.н., проф. каф. хірургї Буковинського ДМУ. Адреса: м. Чернівці, вул. Буковинська, 4; тел.: (0372) 53-84-56.

Іринчин Андрій Васильович - к.мед.н., експерт Департаменту охорони здоров'я Чернівецької ОДА за спеиіальністю «Дитяча урологія». Адреса: м. Чернівиі, вул. Буковинська, 4; телефон: (0372) 53-84-56.

Пастернак Ігор Іванович - к.мед.н., дитячий уролог КНП «Міська дитяча клінічна лікарня» Чернівецької міської ради. Адреса: м. Чернівці, вул. Буковинська, 4 .

Рандюк Роман Юрійович - аспірант каф. дитячої хірургї та отоларингології Буковинського ДМУ. Адреса: м. Чернівці, вул. Буковинська, 4; тел.: (0372) 53-84-56.

Стаття надійшла до редакції 11.06.2021р., прийнята до друку 8.09.2021 p.

\section{ДО УВАГИ АВТОРІВ!}

\section{АЛГОРИТМ РЕЕСТРАЦIÏ ORCID}

Open Researcher and Contributor ID (ORCID) - міжнародний ідентифікатор науковця.

Створення єдиного реєстру науковців та дослідників на міжнародному рівні $\epsilon$ найбільш прогресивною та своєчасною ініціативою світового наукового товариства. Ця ініціатива була реалізована через створення в 2012 році проекту Open Researcher and Contributor ID (ORCID). ORCID - це реєстр унікальних ідентифікаторів вчених та дослідників, авторів наукових праць та наукових організацій, який забезпечує ефективний зв'язок між науковцями та результатами їх дослідницької діяльності, вирішуючи при цьому проблему отримання повної і достовірної інформації про особу вченого в науковій комунікації.

Для того щоб зареєструватися в ORCID через посилання https://orcid.org/ необхідно зайти у розділ «For researchers» і там натиснути на посилання «Register for an ORCID iD». В реєстраційній формі послідовно заповнюються обов'язкові поля: «First name», «Last name», «E-mail», «Re-enter E-mail», «Password» (Пароль), «Confirm password»

В перше поле вводиться ім'я, яке надане при народженні, по-батькові не вводиться. Персональна електронна адреса вводиться двічі для підтвердження. Вона буде використовуватися як Login або ім'я користувача. Якщо раніше вже була використана електронна адреса, яка пропонується для реєстрації, з'явиться попередження червоного кольору. Неможливе створення нового профілю з тією ж самою електронною адресою. Пароль повинен мати не менше 8 знаків, при цьому містити як цифри, так і літери або символи. Пароль, який визначається словами «Good» або «Strong» приймається системою.

Нижче визначається «Default privacy for new works», тобто налаштування конфіденційності або доступності до персональних даних, серед яких «Public», «Limited», «Private».

Далі визначається частота повідомлень, які надсилає ORCID на персональну електронну адресу, а саме, новини або події, які можуть представляти інтерес, зміни в обліковому записі, тощо: «Daily summery», «Weekly summery», "Quaterly summery», «Never». Heобхідно поставити позначку в полі «l'm not a robot» (Я не робот).

Для реєстрації необхідно прийняти умови використання, натиснувши на позначку «I consent to the privacy policy and conditions of use, including public access and use of all my data that are marked Public».

Заповнивши поля реєстраційної форми, необхідно натиснути кнопку «Register», після цього відкривається сторінка профілю учасника в ОRCID з особистим ідентифікатором ORCID ID. Номер ORCID ідентифікатора знаходиться в лівій панелі під ім'ям учасника ORCID.

Структура ідентифікатора ORCID являє собою номер з 16 цифр. Ідентифікатор ORCID - це URL, тому запис виглядає як http://orcid.org/xxxxxxxx-xxxxxxxx.

Наприклад: http://orcid.org/0000-0001-7855-1679.

Інформацію про ідентифікатор ORCID необхідно додавати при подачі публікацій, документів на гранти і в інших науково-дослідницьких процесах, вносити його в різні пошукові системи, наукометричні бази даних та соціальні мережі.

Подальша робота в ORCID полягає в заповненні персонального профілю згідно із інформацією, яку необхідно надавати. 


\title{
Marrero, Jorge A MD'; Ahn, Joseph MD, FACG ${ }^{2}$; Reddy, Rajender K MD, FACG ${ }^{3}$ on behalf of the Practice Parameters Committee of the American College of Gastroenterology
}

\section{ACG Clinical Guideline: The Diagnosis and Management of Focal Liver Lesions ${ }^{*}$}

\author{
${ }^{1}$ University of Texas at Southwestern, Dallas, Texas, USA \\ ${ }^{2}$ Oregon Health and Science University, Portland, Oregon, USA \\ ${ }^{3}$ University of Pennsylvania, Philadelphia, Pennsylvania, USA
}

\begin{abstract}
American Journal of Gastroenterology: September 2014 - Volume 109 - Issue 9 - p 1328-1347. doi: 10.1038/ajg.2014.213.
Focal liver lesions (FLL) have been a common reason for consultation faced by gastroenterologists and hepatologists. The increasing and widespread use of imaging studies has led to an increase in detection of incidental FLL. It is important to consider not only malignant liver lesions, but also benign solid and cystic liver lesions such as hemangioma, focal nodular hyperplasia, hepatocellular adenoma, and hepatic cysts, in the differential diagnosis. In this ACG practice guideline, the authors provide an evidence-based approach to the diagnosis and management of FLL.
\end{abstract}

\section{Preamble}

The writing group was invited by the Practice Parameters Committee and the Board of the Trustees of the American College of Gastroenterology to develop a practice guideline regarding the suggested diagnostic approaches and management of focal liver lesions (FLLs). FLLs are solid or cystic masses or areas of tissue that are identified as an abnormal part of the liver. The term «lesion» rather than «mass» was chosen because «lesion» is a term that has a wider application, including solid and cystic masses. This guideline will be limited to primary liver lesions and the management approach to FLLs rather than focusing on the diagnosis and management of metastatic lesions, hepatocellular carcinoma, or cholangiocarcinoma. For specific reading on these lesions, the reader is referred to other recent guidelines [1-3]. An evidence-based approach was undertaken to critically review the available diagnostic tests and treatment options of FLLs. The following resources were utilized: (I) a formal review and analysis of the published literature using MEDLINE via the OVID interface up to June 2013 with the search terms «hepatic/liver mass,» «hepatic/liver tumor,» «hepatic/liver cancer,» «hepatic/liver lesion,» «hepatocellular adenoma,» «liver adenomatosis,» «hepatic hemangioma,» «focal nodular hyperplasia,» «nodular regenerative hyperplasia,» «hepatic cyst,» «hepatic cystadenoma,» «hepatic cystadenocarcinoma,» «polycystic liver disease,» and «hydatid cyst,» without language restriction; (II) hand reviews of articles known to the authors; and (III) the consensus experiences of the authors and independent reviewers regarding FLLs. The guideline was prepared according to the policies of the American College of Gastroenterology and with the guidance of the Practice Parameters Committee. The GRADE system was used to grade the strength of recommendations and the quality of evidence [4]. $<\ldots>$

\section{Introduction}

Because of the widespread clinical use of imaging modalities such as ultrasonography (US), computed tomography (CT), and magnetic resonance imaging (MRI), previously unsuspected liver lesions are increasingly being discovered in otherwise asymptomatic patients. A recent study indicated that from 1996 to 2010 the use of CT examinations tripled (52/1,000 patients in 1996 to $149 / 1,000$ in 2010, 7.8\% annual growth), MRIs quadrupled (17/1,000 to $65 / 1,000,10 \%$ annual growth); US approximately doubled (134/1,000 to 230/1,000, 3.9\% annual growth), and positron emission tomography (PET) scans increased from $0.24 / 1,000$ patients to $3.6 / 1,000$ patients (57\% annual growth) [5]. More importantly, the evaluation of liver lesions has taken on greater importance because of the increasing incidence of primary hepatic malignancies, especially hepatocellular carcinoma (HCC) and cholangiocarcinoma (CCA). Therefore, a thorough and systematic approach to the management of focal liver lesions (FLLs) is of utmost importance.

\section{Diagnosis of a liver lesion}

The critical components of evaluating an FLL are a detailed history, physical exam, radiological tests, and pathology. For example, a history of oral contraceptive use in the absence of underlying liver disease suggests a diagnosis of

\footnotetext{
* Наведено зі скороченням. Відібрано матеріал для застосування в практичній діяльності дитячих xiрургів. Повний текст за посиланням: https://јоurnals. Iww.com/ajg/fulltext/2014/09000/acg_clinical_guideline_the_diagnosis_and.7.aspx
} 


\section{Міжнародні клінічні протоколи, рекомендації}

\section{Table 2}

Technical considerations for dynamic contrast-enhanced MRI and dynamic contrast-enhanced computerized tomography of the liver

\begin{tabular}{|c|c|}
\hline Feature & Specification \\
\hline \multicolumn{2}{|c|}{ Dynamic contrast-enhanced MRI } \\
\hline Scanner & 1.5-T or dreater main magnetic field strenghth \\
\hline Coil type & Phased array multichannel torso coli \\
\hline Gradient types & Current-generation high-speed gradients (providing sufficient coverage) \\
\hline Injector & Dual-chamber power injector recommended \\
\hline Contrast injector rate & $2-3 \mathrm{ml} / \mathrm{s}$ of gadolinium chelate \\
\hline Minimum sequenced & $\begin{array}{l}\text { Precontrast and dynamic post-gadolinium } \\
\text { T1-weighted gradient echo sequence (3D preferable), T2 (with and without FAT SAT), and } \\
\text { T1w in- and out-of-phase imaging }\end{array}$ \\
\hline $\begin{array}{l}\text { Mandatory dynamic } \\
\text { sequences }\end{array}$ & $\begin{array}{l}\text { (I) Arterial phase. Artery fully enhanced, beginning contrast enhancement of portal vein } \\
\text { (II) Portal venous phase. Portal vein enhanced, peak liver parenchymal enhancement, } \\
\text { beginning contrast enhancement of hepatic vein ( } 30-55 \mathrm{~s} \text { after the initiation of a late } \\
\text { arterial phase scan) } \\
\text { (III) Delayed phase. > } 120 \mathrm{~s} \text { after the initial injection of contrast }\end{array}$ \\
\hline Slice thickness & $5 \mathrm{~mm}$ for dynamic series, $8 \mathrm{~mm}$ for other imaging \\
\hline Breath holding & $\begin{array}{l}\text { Maximum length of series, requiring breath hold should be } \sim 20 \text { s with a minimum matrix } \\
\text { of } 128 \_256\end{array}$ \\
\hline \multicolumn{2}{|c|}{ Dynamic contrast-enhanced computerized tomography of the liver } \\
\hline Scanner type & Multidetector row scanner \\
\hline Detector type & Minimum of 8 detector rows \\
\hline Reconstructed slice thickness & Minimum reconstructed slice thickness of $5 \mathrm{~mm}$ \\
\hline Injector & Power injector, preferably a dual-chamber injector with a saline flush \\
\hline Contrast injector rate & $\begin{array}{l}\text { Not less than } 3 \mathrm{ml} / \mathrm{s} \text { of contrast, } 4-6 \mathrm{ml} / \mathrm{s} \text { better at least } 300 \mathrm{mg} \mathrm{l} / \mathrm{ml} \text { or a higher } \\
\text { concentration for a dose of } 1.5 \mathrm{ml} / \mathrm{kg} \text { of body weight }\end{array}$ \\
\hline $\begin{array}{l}\text { Mandatory dynamic phases } \\
\text { on contrast-enhanced MDCT }\end{array}$ & $\begin{array}{l}\text { (I) Late arterial phase. Artery fully enhanced, beginning contrast enhancement of portal } \\
\text { vein } \\
\text { (II) Portal venous phase. Portal vein enhanced, peak liver parenchymal enhancement, } \\
\text { beginning contrast enhancement of hepatic veins } \\
\text { (III) Delayed phase. Variable appearance, }>120 \mathrm{~s} \text { after the initial injection of contrast }\end{array}$ \\
\hline $\begin{array}{l}\text { FAT SAT, fat saturation; MDC } \\
\text { Adapted from Pomfret et al. }\end{array}$ & ultidetector compluted tomography; MRI, magnetic resonance imaging. \\
\hline
\end{tabular}

hepatocellular adenoma (HCA), whereas an FLL in the setting of chronic liver disease and portal hypertension should lead to a high suspicion of a diagnosis of HCC.

A radiological test is the most important aspect in the evaluation of a liver lesion. Although US is usually the first imaging test obtained because of its safety and low cost, it lacks the performance characteristics that CT and MRI have to diagnose and characterize hepatic lesions [6]. Contrast-enhanced US is an emerging modality that has some utility but is not widely available in the United States. Therefore, we will focus our attention on CT and MRI scans in this guideline.

In the context of HCC and liver transplantation, a recent consensus conference addressed the importance of standardizing the technical specifications for CT and MRI in the diagnosis of HCC [7]. Although this report focused on the specifications for diagnosing HCC, the technical aspects for CT or MRI can also be applied to the evaluation of FLLs as shown in Table 2. The most important aspect is the need for a late arterial phase, a portal venous phase, and a delayed venous phase. In the context of a CT scan, this is referred to as a «triple-phase» study, distinct from a standard abdominal CT that includes only a portal venous phase and a delayed phase. A technically appropriate CT or MRI will give the clinician information about the characteristics of the liver lesion, its location and relationship to anatomical structures (such as the gallbladder and hepatic vasculature), and, in the case of malignancy, allow staging of the tumor.

Technical considerations for dynamic contrast-enhanced MRI and dynamic contrast-enhanced computerized tomography of the liver

Pathological examination is another important aspect in the evaluation of an FLL. The evolution of CT and MRI technology has improved their diagnostic capability to often permit making an accurate diagnosis without the requirement for a liver biopsy. In fact, HCC can be diagnosed with $\geq 90 \%$ accuracy with imaging alone when a lesion is 
$2 \mathrm{~cm}$, thus obviating the need for liver biopsy in nearly all cases under the right clinical circumstances [8]. However, if the diagnosis cannot be reliably made radiologically, a biopsy should be performed. Pathological examination is extremely accurate in making a diagnosis in a patient with an FLL. A well-sampled biopsy specimen has greater diagnostic accuracy and provides more tissue for ancillary testing (i.e., immunohistochemistry) when compared with fine-needle aspiration [9]. A consensus conference on pathology for hepatobiliary malignancies also recommended core biopsies over fine-needle aspiration as it allows for the assessment of both architectural and cytological features [10]. $<\ldots>$

\section{Hepatic hemangioma}

Hepatic hemangiomas are benign vascular liver lesions of unknown etiology that are thought to arise from congenital hamartomas. Alternatively, hepatic hemangiomas could result from dilation of existing blood vessels in tissues that developed normally. The observed increase in the size of the lesions is thought to result from progressive ectasia rather than hyperplasia or hypertrophy [52]. Hepatic hemangiomas are the most common benign hepatic tumors with a prevalence of $0.4-20 \%$ identified during autopsy $[53,90]$. The actual frequency of clinically relevant cases is more likely $0.7-1.5 \%$, as indicated by US studies [91,92].

There is no causal link between hepatic hemangiomas and pregnancy or OCP use. However, hepatic hemangiomas are found earlier, are larger, and are more often found in women than in men, with a 5 to 1 female to male preponderance $[93,94]$. These observations, combined with reports that these lesions grew in size during pregnancy and OCP use, suggested that female sex hormones may have a role in their pathogenesis $[52,95,96]$. However, no direct causal link between OCP use and hepatic hemangioma was found in a case-control study [97]. Thus, the relationship between hormonal involvement and the development of hemangioma is unsubstantiated and is not a precondition for development, as hemangiomas are also observed in men, in women with no history of OCP use, and in postmenopausal women [52].

Table 3

Imaging characteristics of solid liver lesions

\begin{tabular}{|c|c|c|c|}
\hline Lesion & US & CT & MRI \\
\hline $\mathrm{HCA}$ & $\begin{array}{l}\text { Heterogeneous; } \\
\text { hyperechoic if } \\
\text { steatotic but } \\
\text { anechoic center if } \\
\text { hemorrhage }\end{array}$ & $\begin{array}{l}\text { Well demarcated with } \\
\text { peripheral enchancement; } \\
\text { homogenous more often than } \\
\text { heterogeneous; hypodense if } \\
\text { steatotic, hyperdense if } \\
\text { hemorrhagic }\end{array}$ & $\begin{array}{l}\text { HNF1 } \alpha \text { : signal lost on chemical shift; moderate } \\
\text { arterial enchancement during delayed phase } \\
\text { IHCA: markedly hyperintense on T2 with stronger } \\
\text { signal peripherally; persistent enchancement in } \\
\text { delayed phase } \\
\text { B-Catenin: inflammatory subtype has same } \\
\text { appearance as IHCA; noninflammatory is } \\
\text { heterogeneous with no signal droptout on chemical } \\
\text { shift, isointense of T1 and T2 with strong arterial } \\
\text { enchancement and delayed washout }\end{array}$ \\
\hline THCA & $\begin{array}{l}\text { Variable } \\
\text { appearance }\end{array}$ & Hypo- to isoattenuating & $\begin{array}{l}\text { T1: heterogeneous and well-defined iso- to } \\
\text { hyperintense mass. Strongly hyperintense with } \\
\text { persistent contrast enchancement in delayed phase }\end{array}$ \\
\hline Hemangioma & $\begin{array}{l}\text { Hyperechoic with } \\
\text { well-defined rim } \\
\text { and with few } \\
\text { intranodular vessels }\end{array}$ & $\begin{array}{l}\text { Discontinuous peripheral } \\
\text { nodular enchancement } \\
\text { isoattenuating to aorta with } \\
\text { progressive centripetal fill-in }\end{array}$ & $\begin{array}{l}\text { T1: hypointense; discontinuous peripheral } \\
\text { enchancement with centripetal fill-in } \\
\text { T2: hyperintense relative to spleen }\end{array}$ \\
\hline $\mathrm{FNH}$ & Generally isoechoic & $\begin{array}{l}\text { Central scar. Arterial phase } \\
\text { shows homogenous } \\
\text { hyperdense lesion; return to } \\
\text { precontrast density during } \\
\text { portal phase that is hypo- or } \\
\text { isodense }\end{array}$ & $\begin{array}{l}\text { T1: isointense or slightly hypointense. Gadolinium } \\
\text { produces early enchancement with central scar } \\
\text { enchancement during delayed phase } \\
\text { T2: slightly hyperintense or isointense }\end{array}$ \\
\hline $\mathrm{NRH}$ & $\begin{array}{l}\text { Isoechoic/ } \\
\text { hyperechoic }\end{array}$ & $\begin{array}{l}\text { Nonenhancing nodules, } \\
\text { sometimes hypodense, with } \\
\text { variable size (most sub- } \\
\text { centimeter) }\end{array}$ & $\begin{array}{l}\text { T1: hyperintense } \\
\text { T2: varied intensity (hypo/iso/hyperintense) }\end{array}$ \\
\hline \multicolumn{4}{|c|}{$\begin{array}{l}\text { CT, computed tomography; FNH, focal nodular hyperplasia; HCA, hepatocellular adenoma; HNF1 } \alpha \text {, hepatocyte nuclear } \\
\text { factor-1 } \alpha \text {; IHCA, inflammatory hepatocellular adenoma; MRI, magnetic resonance imaging; NRH, nodular regenerative } \\
\text { hyperplasia; THCA, telangiectatic hepatocellular adenoma; US, ultrasonography. } \\
\text { Adapted from Shaked et al. [52] }\end{array}$} \\
\hline
\end{tabular}




\section{Diagnostic characteristics of hepatic hemangioma}

Hepatic hemangiomas can be found in all age groups, although they are typically discovered in those between the ages of 30 and 50 years. Most of these lesions are asymptomatic and are discovered incidentally during imaging studies [52]. Hemangiomas occur with symptoms in $\sim 11-14 \%$ of all hepatic hemangioma cases $[98,99]$. The most common presentations are right upper quadrant pain or a mass felt in the epigastrium. Both are likely secondary to pressure or displacement of adjacent anatomical structures by the lesions. Other common symptoms include severe pain, nausea, dyspepsia, early satiety, vomiting, weight gain, and hepatomegaly [52]. In rare cases, giant hemangiomas may cause consumptive coagulopathy known as Kasabach-Merritt syndrome that manifests as thrombocytopenia, disseminated intravascular coagulation, and systemic bleeding [100].

CT, MRI, and US studies are reliable in establishing a diagnosis of hepatic hemangioma as this lesion displays unique features upon imaging with peripheral nodular enhancement and progressive centripetal fill-in, as outlined in Table 3. MRI is preferred in cases where the lesion is $<3 \mathrm{~cm}$ or found close to the heart or intrahepatic vessels [52]. Contrast-enhanced US, if available, can increase both the sensitivity and specificity of US and is effective in diagnosing hepatic hemangioma [101].

Spontaneous bleeding of hemangiomas is rare. However, owing to its highly vascular nature, biopsy should be avoided because of the risk of potential bleeding. Furthermore, the high sensitivity and specificity of radiologic studies in the diagnosis of hepatic hemangioma obviates the need for a biopsy. In cases of smaller lesions where there is uncertainty in the diagnosis, a follow-up imaging study may be more prudent than a biopsy [52]

\section{Management of hepatic hemangioma}

The majority of hemangiomas are asymptomatic and remain stable over time [102]. Thus, preventing rare complications with surgical intervention is not needed, and instead a conservative approach is advocated. Surgical intervention can be considered in cases where the lesion grows very large $(>10 \mathrm{~cm})$ or the patient begins to report symptomatic compression or recurrent pain [52,103]. Follow-up imaging is not required in cases of classical hemangioma.

\section{Recommendations}

12. An MRI or CT scan should be obtained to confirm a diagnosis of hemangioma (strong recommendation, moderate quality of evidence).

13. Liver biopsy should be avoided if the radiologic features of a hemangioma are present (strong recommendation, low quality of evidence).

14. Pregnancy and the use of oral contraceptives or anabolic steroids are not contraindicated in patients with a hemangioma (conditional recommendation, low quality of evidence).

15. Regardless of the size, no intervention is required for asymptomatic hepatic hemangiomas. Symptomatic patients with impaired quality of life can be referred for surgical or nonsurgical therapeutic modalities by an experienced team (conditional recommendation, low quality of evidence).

$<\ldots>$

\section{Hepatic cysts}

Hepatic cysts typically present for evaluation upon being found incidentally on imaging studies. Early laparotomy series reported a prevalence of 0.2 to $1 \%$ [137]. US series have reported a $3-5 \%$ prevalence in the population, whereas CT series have reported the prevalence to be as high as 15-18\% [138-142]. Given the increased use of cross-sectional imaging, hepatic cysts are an increasingly common finding that has led to a growing awareness of their existence. Table 4_outlines the imaging characteristics of common cystic FLLs. Although the natural history of simple hepatic cysts has not been well elucidated, they are not thought to be premalignant precursors to the development of biliary cystadenomas (BCs) or biliary cystadenocarcinomas (BCAs). Optimal management of incidentally found hepatic cysts is not clear because of the lack of rigorous clinical studies. Nevertheless, it has been observed that the vast majority of hepatic cysts are predominantly benign, and in the absence of characteristic features suggestive of BC, BCA, polycystic liver disease (PCLD), or hydatid cysts they can be managed expectantly. The presence of multiple cysts $(>20)$, large cysts $(>4-5 \mathrm{~cm})$, septations, calcifications, fenestrations, loculations, heterogeneity, daughter cysts, or symptoms on presentation are not characteristic of simple hepatic cysts and should prompt further diagnostic evaluation. Suspected biliary cystadenomas and BCAs should be completely resected. The management of PCLD and hydatid cysts is variable, based on the clinical presentation, the size, location, and number of lesions, as well as the experience of the managing team. 
Table 4

Imaging characteristics of cystic liver lesions

\begin{tabular}{|l|l|l|l|}
\hline Lesion & US & CT & MRI \\
\hline $\begin{array}{l}\text { Simple } \\
\text { (SHC) }\end{array}$ & $\begin{array}{l}\text { Anachoic, } \\
\text { homogeneous, fluid } \\
\text { filled. Smooth margins }\end{array}$ & $\begin{array}{l}\text { Well-demarcated, water- } \\
\text { attenuated, smooth lesion } \\
\text { without an internal structure. } \\
\text { No enchancement with } \\
\text { contrast }\end{array}$ & $\begin{array}{l}\text { Wwell-defined, homogeneous lesion. No } \\
\text { enchancement with contrast } \\
\text { T1: hypointense signal intensity } \\
\text { T2: hyperintense signal intensity }\end{array}$ \\
\hline $\begin{array}{l}\text { Billiary } \\
\text { cystadenomas } \\
\text { (BCs) }\end{array}$ & $\begin{array}{l}\text { Irregular walls, internal } \\
\text { septations forming } \\
\text { loculi }\end{array}$ & $\begin{array}{l}\text { Heterogeneous septations, } \\
\text { internal septations, irregular } \\
\text { papillary growths, thickened } \\
\text { cyst walls }\end{array}$ & $\begin{array}{l}\text { May appear heterogeneous. } \\
\text { T1: hypointense signal intensity } \\
\text { T2: hyperintense signal intensity }\end{array}$ \\
\hline $\begin{array}{l}\text { Polycystic liver } \\
\text { disease (PCLD) }\end{array}$ & $\begin{array}{l}\text { Multiple hepatic cysts, } \\
\text { similar in } \\
\text { characteristics to SHC } \\
\text { US findings }\end{array}$ & $\begin{array}{l}\text { Multiple hepatic cysts, similar } \\
\text { in characteristics to SHC CT } \\
\text { findings }\end{array}$ & $\begin{array}{l}\text { Multiple hepatic cysts, similar in characteristics } \\
\text { to SHC MRI findings }\end{array}$ \\
\hline $\begin{array}{l}\text { Hidatid cysts } \\
\text { (HCs) }\end{array}$ & $\begin{array}{l}\text { May appear similar to } \\
\text { SHC. Progress to } \\
\text { develop thick, calcified } \\
\text { walls, hyperechoic/ } \\
\text { hypoechoic contents. } \\
\text { Daughter cysts in } \\
\text { periphery }\end{array}$ & $\begin{array}{l}\text { Hypidense lesion with } \\
\text { hypervascular pericyst wall, } \\
\text { distinct endocyst wall. } \\
\text { Calcified walls and septa easly } \\
\text { detected. Daughter cysts seen } \\
\text { peripherally within mother } \\
\text { cyst. }\end{array}$ & $\begin{array}{l}\text { T1: hypointense signal intensity of cyst contents. } \\
\text { Typointense rim on T2. } \\
\text { Daughter cysts seen peripherally within mother } \\
\text { cyst. } \\
\text { Collapse parasitic membranes seen as floating } \\
\text { linear structures within cyst. }\end{array}$ \\
\hline \begin{tabular}{l} 
CT, computed tomography; MRI, magnetic resonance imaging; US, ultrasonography. \\
\hline
\end{tabular}
\end{tabular}

\section{Simple hepatic cysts}

Simple hepatic cysts are postulated to be congenital exclusions of hyperplastic bile duct rests that lack a communication with biliary ducts $[93,143]$. They are composed of an outer layer of fibrous tissue and are lined by a cuboidal, columnar epithelium that continually produces cystic fluid [137]. Simple hepatic cysts are usually $<1 \mathrm{~cm}$ and can grow up to $30 \mathrm{~cm}[144,145]$. Simple hepatic cysts are uncommon before the age of 40 years and have a female predilection of 1:4 $[146,147]$. However, there is no clear correlation with oral contraceptive use or pregnancy. They are usually asymptomatic and discovered incidentally, although larger lesions may present with abdominal pain, epigastric fullness, or early satiety. Infrequently, internal hemorrhage, infection, or rapid enlargement can lead to symptoms and presentation for clinical evaluation. Thus, the presence of symptoms or a rapid increase in size on follow-up imaging should lead to consideration of alternative diagnosis such as biliary cystadenoma (BC) or BCA $[148,149]$.

\section{Diagnostic characteristics of simple hepatic cysts}

Ultrasound typically reveals an anechoic, homogenous, fluid-filled lesion with smooth margins. CT shows a welldemarcated, water-attenuated, smooth lesion without an internal structure, and no enhancement with contrast. Similarly, MRI shows a well-defined, homogeneous lesion with low signal intensity on T1 weighting, and high intensity on T2, without contrast enhancement. The differential diagnosis includes BCA, PCLD, hydatid cysts, cystic metastases from primary cystic tumors, and cystic necrosis of large solid neoplasms. Cysts that have internal septations, fenestrations, calcifications, irregular walls, or daughter cysts on US should be evaluated with CT or MRI for features of BCA or hydatid cysts. Aspiration of fluid contents is not needed to diagnose simple hepatic cysts and is not recommended. However, if done, the findings should show normal fluid carbohydrate antigen 19-9 levels and negative testing for cytology.

\section{Management of simple hepatic cysts}

There is a paucity of randomized controlled trials and a lack of long-term follow-up outcome data comparing treatment methods for simple hepatic cysts. These limitations make it difficult to make evidence-based recommendations with strong support from the literature. Nevertheless, several basic dictums are found in the literature that require strong consideration. First, incidentally identified asymptomatic cysts do not need follow-up or treatment [150]. Second, hepatic cysts that are symptomatic because of hemorrhage, rupture, infection, or growth merit intervention. Simple aspiration is not recommended as it leads to universal recurrence. Beyond these basic statements, and once a decision has been made to intervene on a simple hepatic cyst, no definitive, evidence-based recommendations can be made regarding the optimal mode of intervention.

Treatment modality may be determined by the operative candidacy of the patient. Open surgical cyst fenestration, also known as deroofing or marsupialization, which leaves the cysts open to drain into the 
peritoneal cavity, has been reported to be successful in up to $90 \%$ of cases [151-156]. Patients who are not surgical operative candidates or who decline surgery can be managed with radiologic cyst aspiration and sclerotherapy with alcohol or other sclerosants [157]. Although this approach is associated with a high recurrence rate, it may be appropriate for patients who are not surgical candidates [158-160]. Laparoscopic approaches to fenestration were reported beginning in the 1990s, and have been quickly adopted, where available, as the standard approach compared with open laparotomy, because of reported success rates matching open approaches along with reductions in morbidity and length of hospital stay. Laparoscopic deroofing may be the preferred therapeutic strategy where available [157,161-163]. Regardless of the approach, the decision to pursue surgical intervention is often driven by the uncertainty of the underlying diagnosis of simple hepatic cysts, and the inability to unequivocally exclude malignancy without a histological evaluation [164]. Thus, an important factor in selecting surgical intervention is that it allows histological examination of the cyst to exclude biliary cystadenomas and biliary cystadenocarcinomas. Nevertheless, it is imperative to complete a thorough evaluation for alternative causes of the patient's complaints before proceeding with invasive interventions to avoid diagnostic dilemma and therapeutic frustration of persistence of symptoms despite treatment directed toward the ostensibly symptomatic hepatic cyst. Overall, comparison studies between aspiration, fenestration, and laparoscopic versus open approaches have been limited by heterogeneous methods, variable outcomes reported, small number of patients reported, short follow-up times, and single-center experiences [153]. Once intervention has been deemed necessary, the mode of treatment should be dictated by the local availability of surgical and radiologic expertise and patient preference on an individual basis.

\section{Recommendations}

24. A hepatic cyst identified on US with septations, fenestrations, calcifications, irregular walls, or daughter cysts should prompt further evaluation with CT or MRI (strong recommendation, low quality of evidence).

25. Asymptomatic simple hepatic cysts should be observed with expectant management (strong recommendation, moderate quality of evidence).

26. Aspiration of asymptomatic, simple hepatic cysts is not recommended (strong recommendation, low quality of evidence).

27. Symptomatic simple hepatic cysts may be managed with laparoscopic deroofing rather than aspiration and sclerotherapy, dictated based on availability of local expertise (conditional recommendation, low quality of evidence).

\section{Biliary cystadenomas and biliary cystadenocarcinomas}

Biliary cystadenomas are congenitally derived, aberrant bile duct remnants composed of three layers of tissue. Early pathophysiologic suppositions regarding an origin from heterotopic ovarian tissue have been disproven by recent immunohistochemistry and electron microscopy studies [165]. The outer layer of thick collagen and mixed connective tissue surrounds a middle layer of mesenchymal smooth muscle cells and fibroblasts, and an inner lining of cuboidal/columnar epithelium that typically secretes mucin [134]. Grossly, BCs have a heterogeneous interior with septations forming multiple loculations filled with mucinous (95\%) or serous (5\%) material [144]. Some BCs have papillary projections that form thick, compact septa [166-169].

Biliary cystadenomas are reported to constitute up to $1-5 \%$ of total hepatic cysts, and up to $10 \%$ of cysts $>4 \mathrm{~cm}$ [161]. There are no known associations with the use of oral contraceptives, although the 1:4 female predilection suggests a possible hormonal involvement [170]. Although rare, $\mathrm{BC}$ is the most common form of a primary hepatic cystic neoplasm. Biliary cystadenomas are thought to be precursors to the development of BCA, although it is difficult to predict progression or clearly identify characteristics that herald such progression $[144,166,170,171]$. Although symptoms are rare, they are often correlated with the increasing size of the lesions leading to mass effect and abdominal discomfort, nausea, early satiety, or anorexia [155,170]. Smaller BCs are typically discovered incidentally on imaging. The presence of calcifications along with mixed solid and cystic components on imaging as well as constitutional symptoms has been reported to be associated with BCA.

\section{Diagnostic characteristics of biliary cystadenomas}

US typically shows irregular walls and internal septations forming loculi. US is most sensitive in identifying these internal septations. If a complex cyst is found on US, cross-sectional imaging with CT and MRI should be obtained. CT and MRI can help confirm the findings of heterogeneous septations, irregular papillary growths, and thickened cyst walls $[172,173]$. The cysts are typically hyperintense on T2 weighting, although because of mucinous content they may appear heterogeneous [174]. Aspiration and biopsy is not recommended for focusing the differential because it has limited sensitivity and can disseminate malignancy if there is underlying BCA $[175,176]$. 
Although imaging can suggest the possibility of $\mathrm{BC}$ or BCA, surgical resection is ultimately necessary to confirm and treat the suspected BC or BCA.

\section{Management of biliary cystadenomas}

If $\mathrm{BC}$ or $\mathrm{BCA}$ is suspected on imaging, referral for surgical consultation should be made. Full surgical excision of any suspected $\mathrm{BC}$ is recommended given the high risk of recurrence, difficulty in preoperative differentiation and exclusion, and possible risk of progression to BCA if only partial excision is performed [169,177-179]. Because of the presence of pseudocapsules, enucleation may be a feasible alternative [180]. There is a dearth of trials comparing laparoscopy versus open laparotomy in managing BC or BCAs. Although data are limited, where available, the laparoscopic approach has gradually replaced open laparotomy as the modality of choice in surgical intervention for BC and BCA based on reported reductions in surgical morbidity and complications. Preference should be given for referral to an experienced surgical team given the challenges of both open and laparoscopic approaches to $\mathrm{BC}$ and $\mathrm{BCA}$ excision $[152,181]$. If the patient is not a surgical candidate, monitoring with repeat imaging should be performed.

\section{Recommendations}

28. Routine fluid aspiration is not recommended when BCA is suspected because of limited sensitivity and the risk of malignant dissemination (strong recommendation, low quality of evidence).

29. Imaging characteristics suggestive of $\mathrm{BC}$ or $\mathrm{BCA}$, such as internal septations, fenestrations, calcifications, or irregular walls, should lead to referral for surgical excision (strong recommendation, low quality of evidence).

30. Complete surgical excision, by an experienced team, is recommended if $\mathrm{BC}$ or BCA is suspected (strong recommendation, low quality of evidence).

\section{Polycystic liver disease}

PCLD is thought to be a part of a clinical spectrum of ciliopathies including congenital hepatic fibrosis, choledochal cysts, microhamartomas, and Caroli's disease that are associated with mutations that impair cholangiocyte ciliary function. PCLD is characterized by the presence of extensive hepatic cysts that are microscopically similar to simple hepatic cysts but more numerous (usually $>20$ ) and larger [182]. Descriptions of the various types of PCLD are beyond the scope of this guideline, but can be summarized as three main types. The most common is autosomal dominant polycystic kidney disease with PCLD. The majority of these patients have renal failure from renal cysts, and $60 \%$ have phenotypic expression of multiple hepatic cysts $[183,184]$. Autosomal dominant PCLD has a more benign prognosis compared with polycystic kidney disease and is mainly asymptomatic [185]. The rarest is autosomal recessive polycystic kidney disease that has a high infant mortality and in which hepatic cysts are not a prominent feature.

\section{Diagnostic characteristics of PCLD}

PCLD is rare with autopsy series reporting $0.13 \%$ and US studies reporting $0.9 \%$ prevalence $[141,186]$. There is a female predilection and a noted increase in the size of hepatic cysts and symptoms with age. Pregnancy and female hormones are also thought to be risk factors for an increase in the size and number of hepatic cysts [147]. PCLD tends to be asymptomatic until the size and number of cysts increase to a critical level. Patients are typically more likely to have hepatomegaly and symptoms from mass effect, such as abdominal bloating, pain, fullness, and shortness of breath, when the cyst to hepatic parenchyma ratio becomes $>1$. Patients may also present with complications such as traumatic rupture, infection, bleeding, extrinsic compression of the biliary tree or gastrointestinal tract, and compression of the inferior vena cava [187]. In advanced cases, patients may develop portal hypertension with relatively preserved hepatic synthetic function [188]. The diagnosis of PCLD is supported by the presence of multiple hepatic cysts on US, CT, or MRI. CT or MRI may provide additional information to exclude other disease processes and to evaluate for the presence of concomitant renal cysts.

\section{Management of PCLD}

Treatment of PCLD is guided by the presence of symptoms that are often directly related to the volume of the liver rather than to specific cysts. Therefore, treatment should be focused on decompressing the liver or reducing the cyst volume as much and as safely as possible. Some recent interest in medical therapy has been stirred by reports of the use of somatostatin analogs and mammalian target of rapamycin inhibitors [189-195]. However, despite these promising reports, their use outside of clinical studies cannot be recommended at this point because of uncertainty regarding their long-term efficacy, safety, as well as optimal dosing and duration of treatment. 
The data defining the optimal management choice for PCLD between aspiration, fenestration, resection, and transplantation as well as between laparoscopic versus open approaches are limited to small-scale clinical series or case reports. Thus, treatment should be guided by the principle of selecting the least invasive procedure that provides the most effective treatment response and improvement in the quality of life. Aspiration of a large, single cyst or a small number of large cysts may be appropriate, although associated with high recurrence rates. Deroofing or fenestration can provide a less transient response, although it is still associated with a 30-70\% recurrence. Growth of multiple hepatic cysts stretches and distorts the anatomy, making it difficult to recognize and avoid damage to bile ducts and vasculature during surgical intervention. Complications such as ascites, hemorrhage, bile leakage, and pleural effusion can occur from such inadvertent damage $[162,182,196]$. In addition to these complications, hepatic resection also carries the risk of hepatic insufficiency if an inadequate hepatic remnant is left. Moreover, resection and surgical treatment can cause adhesions that may complicate possible future procedures such as liver transplantation. Thus, treatment must be tailored to the individual presentation, cyst size and location, vascular patency, and hepatic reserve $[197,198]$. Despite the challenges of these surgical interventions, the laparoscopic approach has been widely adopted, where available [151,152]. Finally, liver transplantation with or without concomitant kidney transplantation has been reported for very symptomatic patients with hepatic failure and/or poor quality of life [162,199-202]. Outcomes have been reported to be comparable or superior to other indications for liver transplantation, with 1 -year survival of $90 \%$ and 5-year survival of 70-80\% [203,204]. Nevertheless, strong recommendations cannot be made because of the overall limitations of the currently available data.

\section{Recommendations}

31. Routine medical therapy with mammalian target of rapamycin inhibitors or somatostatin analogs is not recommended (strong recommendation, low quality of evidence).

32. Aspiration, deroofing, resection of a dominant cyst can be performed based on the patient's clinical presentation and underlying hepatic reserve (conditional recommendation, low quality of evidence).

33. Liver transplantation with or without kidney transplantation can be considered in patients with refractory symptoms and significant cyst burden (conditional recommendation, low quality of evidence).

\section{Hydatid cysts}

Hydatid cysts, or cystic echinococcosis, are most common in patients from sheep-grazing areas such as the Mediterranean, South America, Australia, and East Africa. Hydatid cysts are due to Echinococcus granulosus infection in which humans serve as accidental intermediate hosts when they eat food contaminated with echinococcus eggs or eat organ meat from infected animals such as sheep or cows. The eggs hatch in the human host small intestine and penetrate into the vasculature and then into the liver and lungs. The cysts become visible in the liver at 3 to 4 weeks and grow into a mature cyst that has a germinal layer surrounding a fluid-filled central hydatid cavity. The cysts develop an ectocyst or pericyst in response to the compressive forces of the host's liver parenchyma. The cyst can have high pressure from fluid production that can lead to rupture after trauma or operative manipulation.

Most small cysts, $<5 \mathrm{~cm}$, are asymptomatic. Larger cysts can elicit an inflammatory reaction and may lead to abdominal pain. An acute presentation with pain should lead to consideration of rupture or secondary infection of the cyst. The incidental rupture or iatrogenic puncture of the cyst with spillage of its antigenic contents can lead to a severe allergic reaction, leading to ascites, peritonitis, and shock. Rarely, the cysts can extrude into the biliary tree, leading to jaundice and cholangitis.

\section{Diagnostic characteristics of hydatid cysts}

On US, small hydatid cysts may appear similar to simple hepatic cysts as a unilocular collection. With progression, the lesions may develop a thick, often calcified wall and daughter cysts in the periphery of the main cyst. A classification system has been proposed by the World Health Organization (WHO) Informal Working Group on Echinococcosis in an attempt to classify hydatid cysts based on US findings correlated to their activity and natural history. This has superseded the Gharbi classification [205]. However, the interobserver variability in classifying the stage as well as uncertainty regarding the natural history of hydatid cysts has led to limitations in the utilization of these classification systems in routine clinical practice. CT and MRI can provide more precise information on the cyst morphology and presence of daughter cysts and should be obtained if hydatid cysts are suspected [206]. MRI is preferred for presurgical evaluation to look for cystobiliary communication and evaluate cystic content characteristics. 


\section{Management of hydatid cysts}

Treatment of hydatid cysts depends on the size, location, and symptoms of the cysts as well as the availability of clinical expertise and patient preferences [207]. The evidence level is low regarding treatment modality comparisons in terms of efficacy and safety. Asymptomatic, inactive, calcified hydatid cysts can be managed expectantly. Chemotherapy alone with antihelminthic drugs such as albendazole and mebendazole for symptomatic hydatid cysts is generally not utilized unless the patient is not a candidate for primary percutaneous or surgical treatment, has multiorgan dissemination, or declines other intervention. A systematic review that reported that $>40 \%$ of hydatid cysts remain active or reactivate after 2 years of monotherapy with chemotherapy has dampened enthusiasm for the approach of expectant management [208]. Chemotherapy as an adjunct treatment to other modalities is recommended before and after percutaneous treatment or surgery to prevent relapse $[209,210]$. Nevertheless, strong recommendations regarding the timing of treatment initiation and conclusion, exact duration of treatment, and optimal dosing regimens cannot be made on the basis of currently available data. Traditionally, expert opinion has recommended that chemotherapy be started before the procedure and at least 1 month to 6 months afterward [211].

PAIR (puncture, aspiration, injection, and reaspiration) is a percutaneous treatment alternative to surgery [211-215]. Two randomized controlled trials and a meta-analysis based on these trials reported that PAIR with adjunct antihelminthic chemotherapy is as effective as open surgical drainage with fewer complications and lower cost $[212,216,217]$. PAIR is recommended for patients with active hydatid cysts $>5 \mathrm{~cm}$ who are not candidates for or decline surgery, or who relapse after surgery. PAIR is not recommended in patients with biliary fistulas or communications with the biliary tree because of the risk of biliary sclerosis. PAIR is also contraindicated in patients with inaccessible cysts, or with complicated, multivesiculated cysts, because they may not respond favorably as compared with simple hepatic cysts [218,219]. A recent review of studies on hydatid cyst-associated anaphylaxis found that the risk of lethal anaphylaxis related to percutaneous treatment was extremely rare at $0.03 \%$ of reported procedures [220].

Surgical treatment, either radical pericystectomy or conservative deroofing, has been reserved for complicated cysts that have fistulas, multiple daughter vesicles, rupture, hemorrhage, or secondary infection. Surgery also remains an option when percutaneous treatment such as PAIR is not available. Laparoscopic approaches have been reported to be effective, but quality data on comparison with open surgical approaches or PAIR are highly limited [214,221223]. Overall, the majority of studies are heterogeneous small series, retrospective reports with overlapping patients, limiting the quality of the evidence on which to make strong recommendations on management $[224,225]$.

\section{Recommendations}

34. MRI is preferred over CT for concomitant evaluation of the biliary tree and cystic contents (conditional recommendation, low quality of evidence).

35. Monotherapy with antihelminthic drugs is not recommended in symptomatic patients who are surgical or percutaneous treatment candidates (strong recommendation, moderate quality of evidence).

36. Adjunctive therapy with antihelminthic therapy is recommended in patients undergoing PAIR or surgery, and in those with peritoneal rupture or biliary rupture (strong recommendation, low quality of evidence).

37. Percutaneous treatment with PAIR is recommended for patients with active, hydatid cysts who are not surgical candidates, who decline surgery, or who relapse after surgery (strong recommendation, low quality of evidence).

38. Surgery, either laparoscopic or open, based on available expertise, is recommended in complicated hydatid cysts with multiple vesicles, daughter cysts, fistulas, rupture, hemorrhage, or secondary infection (strong recommendation, low quality of evidence).

$<\ldots>$

\section{References}

1. Bruix J, Sherman M, American Association for the Study of Liver. Management of hepatocellular carcinoma: an update. Hepatology 2011;53:1020-1022.

2. Khan SA, Davidson BR, Goldin RD et al. Guidelines for the diagnosis and treatment of cholangiocarcinoma: an update. Gut 2012;61:1657-1669.

3. European Association For The Study Of The Liver; European Organisation For Research And Treatment Of Cancer. EASL-EORTC clinical practice guidelines: management of hepatocellular carcinoma. J Hepatol 2012;56:908-943.

4. Guyatt GH, Oxman AD, Vist GE et al. GRADE: an emerging consensus on rating quality of evidence and strength of recommendations. BMJ 2008;336:924-926.

5. Smith-Bindman R, Miglioretti DL, Johnson E et al. Use of diagnostic imaging studies and associated radiation exposure for patients enrolled in large integrated health care systems, 1996-2010. JAMA 2012;307:2400-2409. 


\section{Міжнародні клінічні протоколи, рекомендащї}

6. Ros PR, Mortele KJ. Hepatic imaging. An overview. Clin Liver Dis 2002;6:1-16.

7. Pomfret EA, Washburn K, Wald C et al. Report of a national conference on liver allocation in patients with hepatocellular carcinoma in the United States. Liver Transpl 2010;16:262-278.

8. Di Martino M, De Filippis G, De Santis A et al. Hepatocellular carcinoma in cirrhotic patients: prospective comparison of US CT and MR imaging. Eur Radiol 2013;23:887-896.

9. Quinn SF, Nelson HA, Demlow TA. Thyroid biopsies: fine-needle aspiration biopsy versus spring-activated core biopsy needle in 102 patients. J Vasc Interv Radiol 1994;5:619-623.

10. International Consensus Group for Hepatocellular NeoplasiaThe International Consensus Group for Hepatocellular Neoplasia. Pathologic diagnosis of early hepatocellular carcinoma: a report of the international consensus group for hepatocellular neoplasia. Hepatology 2009;49:658-664.

$<\ldots>$

52. Shaked O, Siegelman ES, Olthoff K et al. Biologic and clinical features of benign solid and cystic lesions of the liver. Clin Gastroenterol Hepatol 2011;9:547-562 e1-4.

53. Craig JR, Peters RL, Edmondson HA et al. Tumors of the liver and intrahepatic bile ducts. Atlas of Tumor Pathology, Washington, DC: Armed Forces Institute of Pathology: Supt. of Docs., U.S. G.P. O. For sale by the Armed Forces Institute of Pathology. 280 p 1989. $<\ldots>$

90. Karhunen PJ. Benign hepatic tumours and tumour like conditions in men. J Clin Pathol 1986;39:183-188.

91. Gibney RG, Hendin AP, Cooperberg PL. Sonographically detected hepatic hemangiomas: absence of change over time. AJR Am J Roentgenol 1987;149:953-957.

92. Rungsinaporn K, Phaisakamas T. Frequency of abnormalities detected by upper abdominal ultrasound. J Med Assoc Thai 2008;91:1072-1075.

93. Mergo PJ, Ros PR. Benign lesions of the liver. Radiol Clin North Am 1998;36:319-331.

94. Gandolfi L, Leo P, Solmi L et al. Natural history of hepatic haemangiomas: clinical and ultrasound study. Gut 1991;32:677-680.

95. Saegusa T, Ito K, Oba N et al. Enlargement of multiple cavernous hemangioma of the liver in association with pregnancy. Intern Med 1995;34:207-211.

96. Conter RL, Longmire WP Jr. Recurrent hepatic hemangiomas. Possible association with estrogen therapy. Ann Surg 1988;207:115-119.

97. Gemer O, Moscovici O, Ben-Horin CL et al. Oral contraceptives and liver hemangioma: a case-control study. Acta Obstet Gynecol Scand 2004;83:1199-1201.

98. Tait N, Richardson AJ, Muguti G et al. Hepatic cavernous haemangioma: a 10 year review. Aust N Z J Surg 1992;62:521-524.

99. Park WC, Rhillips R. The role of radiation therapy in the management of hemangiomas of the liver. JAMA 1970;212:1496-1498.

100. Kasabach HH, Merritt KK. Capillary hemangioma with extensive purpura: report of a case. Am J Dis Children 1940;59:1063-1070.

101. Quaia E, Calliada F, Bertolotto M et al. Characterization of focal liver lesions with contrast-specific US modes and a sulfur hexafluoridefilled microbubble contrast agent: diagnostic performance and confidence. Radiology 2004;232:420-430.

102. Farges O, Daradkeh S, Bismuth H. Cavernous hemangiomas of the liver: are there any indications for resection? World J Surg 1995;19:19-24.

103. Ehrl D, Rothaug K, Herzog P et al. 'Incidentaloma' of the liver: management of a diagnostic and therapeutic dilemma. HPB Surg 2012;2012:891787.

$<\ldots>$

134. Trotter JF, Everson GT. Benign focal lesions of the liver. Clin Liver Dis 2001;5:17-42, v.

137. Sanfelippo PM, Beahrs OH, Weiland LH. Cystic disease of the liver. Ann Surg 1974;179:922-925.

138. Caremani M, Vincenti A, Benci A et al. Ecographic epidemiology of non-parasitic hepatic cysts. J Clin Ultrasound 1993;21:115-118.

139. Carrim ZI, Murchison JT. The prevalence of simple renal and hepatic cysts detected by spiral computed tomography. Clin Radiol 2003;58:626-629.

140. Gaines PA, Sampson MA. The prevalence and characterization of simple hepatic cysts by ultrasound examination. Br J Radiol 1989;62:335-337.

141.Larssen TB, Rørvik J, Hoff SR et al. The occurrence of asymptomatic and symptomatic simple hepatic cysts. A prospective, hospital-based study. Clin Radiol 2005;60:1026-1029.

142. Oto A, Tamm EP, Szklaruk J. Multidetector row CT of the liver. Radiol Clin North Am 2005;43:827-848, vii.

143. Ammori BJ, Jenkins BL, Lim PC et al. Surgical strategy for cystic diseases of the liver in a western hepatobiliary center. World J Surg 2002;26:462-469.

144. Bahirwani R, Reddy KR. Review article: the evaluation of solitary liver masses. Aliment Pharmacol Ther 2008;28:953-965.

145. Nisenbaum HL, Rowling SE. Ultrasound of focal hepatic lesions. Semin Roentgenol 1995;30:324-346.

146. Charlesworth P, Ade-Ajayi N, Davenport M. Natural history and long-term follow-up of antenatally detected liver cysts. J Pediatr Surg 2007;42:494-499.

147. Reid-Lombardo KM, Khan S, Sclabas G. Hepatic cysts and liver abscess. Surg Clin North Am 2010;90:679-697.

148. Gadzijev E, Dragan S, Verica FM et al. Hepatobiliary cystadenoma protruding into the common bile duct, mimicking complicated hydatid cyst of the liver. Report of a case. Hepatogastroenterology 1995;42:1008-1010.

149. Taylor BR, Langer B. Current surgical management of hepatic cyst disease. Adv Surg 1997;31:127-148.

150. Doty JE, Tompkins RK. Management of cystic disease of the liver. Surg Clin North Am 1989;69:285-295.

151. Gall TM, Oniscu GC, Madhavan K et al. Surgical management and long-term follow-up of non-parasitic hepatic cysts. HPB (Oxford) 2009;11:235-241.

152. Gamblin TC, Holloway SE, Heckman JT et al. Laparoscopic resection of benign hepatic cysts: a new standard. J Am Coll Surg 2008;207:731-736.

153. Mazza OM, Fernandez DL, Pekolj J et al. Management of nonparasitic hepatic cysts. J Am Coll Surg 2009;209:733-739.

154. Moorthy K, Mihssin N, Houghton PW. The management of simple hepatic cysts: sclerotherapy or laparoscopic fenestration. Ann R Coll Surg Engl 2001;83:409-414.

155. Regev A, Reddy KR, Berho M et al. Large cystic lesions of the liver in adults: a 15-year experience in a tertiary center. J Am Coll Surg 2001;193:36-45.

156. Wahba R, Kleinert R, Prenzel K et al. Laparoscopic deroofing of nonparasitic liver cysts with or without greater omentum flap. Surg Laparosc Endosc Percutan Tech 2011;21:54-58.

157. Tocchi A, Mazzoni G, Costa G et al. Symptomatic nonparasitic hepatic cysts: options for and results of surgical management. Arch Surg 2002;137:154-158. 


\section{Міжнародні клінічні протоколи, рекомендаціі}

158. Erdogan D, van Delden OM, Rauws EA et al. Results of percutaneous sclerotherapy and surgical treatment in patients with symptomatic simple liver cysts and polycystic liver disease. World J Gastroenterol 2007;13:3095-3100.

159. Larssen TB, Rørvik J, Horn A et al. Biochemical and cytologic analysis of cystic contents in benign non-parasitic symptomatic hepatic cysts before and after ethanol sclerotherapy. Acta Radiol 2004;45:504-509.

160. Saini S, Mueller PR, Ferrucci JT Jr et al. Percutaneous aspiration of hepatic cysts does not provide definitive therapy. AJR Am J Roentgenol 1983;141:559-560.

161. Garcea G, Pattenden CJ, Stephenson J et al. Nine-year single-center experience with nonparastic liver cysts: diagnosis and management. Dig Dis Sci 2007;52:185-191.

162. Garcea G, Rajesh A, Dennison AR. Surgical management of cystic lesions in the liver. ANZ J Surg 2013;83:516-522.

163. Palanivelu C, Jani K, Malladi V. Laparoscopic management of benign nonparasitic hepatic cysts: a prospective nonrandomized study. South Med J 2006;99:1063-1067.

164. Fong ZV, Wolf AM, Doria C et al. Hemorrhagic hepatic cyst: report of a case and review of the literature with emphasis on clinical approach and management. J Gastrointest Surg 2012;16:1782-1789.

165.Emre A, Serin KR, Ozden I et al. Intrahepatic biliary cystic neoplasms: surgical results of 9 patients and literature review. World J Gastroenterol 2011;17:361-365.

166. Devaney K, Goodman ZD, Ishak KG. Hepatobiliary cystadenoma and cystadenocarcinoma. A light microscopic and immunohistochemical study of 70 patients. Am J Surg Pathol 1994;18:1078-1091.

167.Lam MM, Swanson PE, Upton MP et al. Ovarian-type stroma in hepatobiliary cystadenomas and pancreatic mucinous cystic neoplasms: an immunohistochemical study. Am J Clin Pathol 2008;129:211-218.

168. Lee JH, Chen DR, Pang SC et al. Mucinous biliary cystadenoma with mesenchymal stroma: expressions of CA 19-9 and carcinoembryonic antigen in serum and cystic fluid. J Gastroenterol 1996;31:732-736.

169. Lee JH, Lee KG, Park HK et al. Biliary cystadenoma and cystadenocarcinoma of the liver: 10 cases of a single center experience. Hepatogastroenterology 2009;56:844-849.

170. Ishak KG, Willis GW, Cummins SD et al. Biliary cystadenoma and cystadenocarcinoma: report of 14 cases and review of the literature. Cancer 1977;39:322-338.

171. Marsh JL, Dahms B, Longmire WP Jr. Cystadenoma and cystadenocarcinoma of the biliary system. Arch Surg 1974;109:41-43.

172. Kim JY, Kim SH, Eun HW et al. Differentiation between biliary cystic neoplasms and simple cysts of the liver: accuracy of CT. AJR Am J Roentgenol 2010;195:1142-1148.

173. Wilson SR, Burns PN, Muradali D et al. Harmonic hepatic US with microbubble contrast agent: initial experience showing improved characterization of hemangioma, hepatocellular carcinoma, and metastasis. Radiology 2000;215:153-161.

174. Williams DM, Vitellas KM, Sheafor D. Biliary cystadenocarcinoma: seven year follow-up and the role of MRI and MRCP. Magn Reson Imaging 2001;19:1203-1208.

175.Dixon E, Sutherland FR, Mitchell P et al. Cystadenomas of the liver: a spectrum of disease. Can J Surg 2001;44:371-376.

176. Hai S, Hirohashi K, Uenishi T et al. Surgical management of cystic hepatic neoplasms. J Gastroenterol 2003;38:759-764.

177. Hansman MF, Ryan JA Jr, Holmes JH IV et al. Management and long-term follow-up of hepatic cysts. Am J Surg 2001;181:404-410.

178. Sanchez H, Gagner M, Rossi RL et al. Surgical management of nonparasitic cystic liver disease. Am J Surg 1991;161:113-118; discussion 118-9.

179. Vogt DP, Henderson JM, Chmielewski E. Cystadenoma and cystadenocarcinoma of the liver: a single center experience. J Am Coll Surg 2005;200:727-733.

180. Delis SG, Touloumis Z, Bakoyiannis A et al. Intrahepatic biliary cystadenoma: a need for radical resection. Eur J Gastroenterol Hepatol 2008;20:10-14.

181.Jain P, Jha AK, Rai RR. Cystic hepatic metastasis from gastrointestinal stromal tumor prior to imatinib mimicking a liver abscess. J Gastrointestin Liver Dis 2009;18:121-122.

182. Drenth JP, Chrispijn M, Nagorney DM et al. Medical and surgical treatment options for polycystic liver disease. Hepatology 2010;52:2223-2230.

183. Chandok N. Polycystic liver disease: a clinical review. Ann Hepatol 2012;11:819-826.

184. Torres VE, Harris PC. Autosomal dominant polycystic kidney disease: the last 3 years. Kidney Int 2009;76:149-168.

185. Qian Q. Isolated polycystic liver disease. Adv Chronic Kidney Dis 2010;17:181-189.

186. Kwok MK, Lewin KJ. Massive hepatomegaly in adult polycystic liver disease. Am J Surg Pathol 1988;12:321-324.

187. Sallee M, Rafat C, Zahar JR et al. Cyst infections in patients with autosomal dominant polycystic kidney disease. Clin J Am Soc Nephrol 2009;4:1183-1189.

188. Chauveau D, Fakhouri F, Grunfeld JP. Liver involvement in autosomal-dominant polycystic kidney disease: therapeutic dilemma. J Am Soc Nephrol 2000;11:1767-1775.

189. Caroli A, Antiga L, Cafaro M et al. Reducing polycystic liver volume in ADPKD: effects of somatostatin analogue octreotide. Clin J Am Soc Nephrol 2010;5:783-789.

190.Chrispijn M, Nevens F, Gevers TJ et al. The long-term outcome of patients with polycystic liver disease treated with lanreotide. Aliment Pharmacol Ther 2012;35:266-274.

191. Hogan MC, Masyuk TV, Page LJ et al. Randomized clinical trial of long-acting somatostatin for autosomal dominant polycystic kidney and liver disease. J Am Soc Nephrol 2010;21:1052-1061.

192. Serra AL, Poster D, Kistler AD et al. Sirolimus and kidney growth in autosomal dominant polycystic kidney disease. N Engl J Med 2010;363:820-829.

193. Tao Y, Kim J, Schrier RW et al. Rapamycin markedly slows disease progression in a rat model of polycystic kidney disease. J Am Soc Nephrol 2005;16:46-51.

194.van Keimpema L, Nevens F, Vanslembrouck R et al. Lanreotide reduces the volume of polycystic liver: a randomized, double-blind, placebocontrolled trial. Gastroenterology 2009;137:1661-1668 e1-2.

195. Walz G, Budde K, Mannaa M et al. Everolimus in patients with autosomal dominant polycystic kidney disease. N Engl J Med 2010;363:830-840.

196. Robinson TN, Stiegmann GV, Everson GT. Laparoscopic palliation of polycystic liver disease. Surg Endosc 2005;19:130-132.

197. Aussilhou B, Douflé G, Hubert C et al. Extended liver resection for polycystic liver disease can challenge liver transplantation. Ann Surg 2010;252:735-743. 


\section{Міжнародні клінічні протоколи, рекомендації}

198. Que F, Nagorney DM, Gross JB Jr et al. Liver resection and cyst fenestration in the treatment of severe polycystic liver disease. Gastroenterology 1995;108:487-494.

199. Kirchner GI, Rifai K, Cantz T et al. Outcome and quality of life in patients with polycystic liver disease after liver or combined liver-kidney transplantation. Liver Transpl 2006;12:1268-1277.

200. Morgan DE, Lockhart ME, Canon CL et al. Polycystic liver disease: multimodality imaging for complications and transplant evaluation. Radiographics 2006;26:1655-1668; quiz 1655.

201. Russell RT, Pinson CW. Surgical management of polycystic liver disease. World J Gastroenterol 2007;13:5052-5059.

202.Schnelldorfer T, Torres VE, Zakaria S et al. Polycystic liver disease: a critical appraisal of hepatic resection, cyst fenestration, and liver transplantation. Ann Surg 2009;250:112-118.

203. Chandok N, Uhanova J, Marotta P. Clinical outcomes of liver transplantation for polycystic liver disease: a single center experience. Ann Hepatol 2010;9:278-281.

204.van Keimpema L, Nevens F, Adam R et al. Excellent survival after liver transplantation for isolated polycystic liver disease: an European Liver Transplant Registry study. Transpl Int 2011;24:1239-1245.

205. WHO Informal Working Group. International classification of ultrasound images in cystic echinococcosis for application in clinical and field epidemiological settings. Acta Trop 2003;85:253-261.

206. von Sinner WN. New diagnostic signs in hydatid disease; radiography, ultrasound CT and MRI correlated to pathology. Eur J Radiol 1991;12:150-159.

207. WHO Informal Working Group on Echinococcosis. Guidelines for treatment of cystic and alveolar echinococcosis in humans. Bull World Health Organ 1996;74:231-242.

208. Stojkovic M, Zwahlen M, Teggi A et al. Treatment response of cystic echinococcosis to benzimidazoles: a systematic review. PLoS Negl Trop Dis 2009;3:e524.

209. Kjossev KT, Losanoff JE. Classification of hydatid liver cysts. J Gastroenterol Hepatol 2005;20:352-359.

210.Smego RA Jr, Bhatti S, Khaliq AA et al. Percutaneous aspiration-injection-reaspiration drainage plus albendazole or mebendazole for hepatic cystic echinococcosis: a meta-analysis. Clin Infect Dis 2003;37:1073-1083.

211. Brunetti E, Kern P, Vuitton DA et al. Expert consensus for the diagnosis and treatment of cystic and alveolar echinococcosis in humans. Acta Trop 2010;114:1-16.

212. Nasseri Moghaddam S, Abrishami A, Malekzadeh R. Percutaneous needle aspiration, injection, and reaspiration with or without benzimidazole coverage for uncomplicated hepatic hydatid cysts. Cochrane Database Syst Rev 2006:1: CD003623.

213. Sahin M, Kartal A, Haykir R et al. RF-assisted cystectomy and pericystectomy: a new technique in the treatment of liver hydatid disease. Eur Surg Res 2006;38:90-93.

214. Yagci G, Ustunsoz B, Kaymakcioglu N et al. Results of surgical, laparoscopic, and percutaneous treatment for hydatid disease of the liver: 10 years experience with 355 patients. World J Surg 2005;29:1670-1679.

215.Zacharoulis D, Poultsidis A, Roundas C et al. Liver hydatid disease: radiofrequency-assisted pericystectomy. Ann R Coll Surg Engl 2006;88:499-500.

216. Khuroo MS, Dar MY, Yattoo GN et al. Percutaneous drainage versus albendazole therapy in hepatic hydatidosis: a prospective, randomized study. Gastroenterology 1993;104:1452-1459.

217. Khuroo MS, Wani NA, Javid G et al. Percutaneous drainage compared with surgery for hepatic hydatid cysts. N Engl J Med 1997;337:881-887.

218. Giorgio A, Tarantino L, de Stefano G et al. Hydatid liver cyst: an 11-year experience of treatment with percutaneous aspiration and ethanol injection. J Ultrasound Med 2001;20:729-738.

219. Kabaalioglu A, Ceken K, Alimoglu E et al. Percutaneous imaging-guided treatment of hydatid liver cysts: do long-term results make it a first choice? Eur J Radiol 2006;59:65-73.

220. Neumayr A, Troia G, de Bernardis C et al. Justified concern or exaggerated fear: the risk of anaphylaxis in percutaneous treatment of cystic echinococcosis-a systematic literature review. PLoS Negl Trop Dis 2011;5:e1154.

221. Daradkeh S, El-Muhtaseb H, Farah G et al. Predictors of morbidity and mortality in the surgical management of hydatid cyst of the liver. Langenbecks Arch Surg 2007;392:35-39.

222. Koea JB. Laparoscopic treatment of hepatic hydatid disease. ANZ J Surg 2012;82:499-504.

223. Palanivelu C, Jani K, Malladi V et al. Laparoscopic management of hepatic hydatid disease. JSLS 2006;10:56-62.

224. Dziri C, Haouet K, Fingerhut A et al. Management of cystic echinococcosis complications and dissemination: where is the evidence? World J Surg 2009;33:1266-1273.

225. Smego RA Jr, Sebanego P. Treatment options for hepatic cystic echinococcosis. Int J Infect Dis 2005;9:69-76. 


\title{
Пам’яті Ади Іванівни Чанг...
}

\author{
14 вересня 2021 року пішла з життя \\ Ада Іванівна Чанг. \\ Ада Іванівна народилася 18 грудня 1926 року \\ в родині службовців ум. Одесі.
}

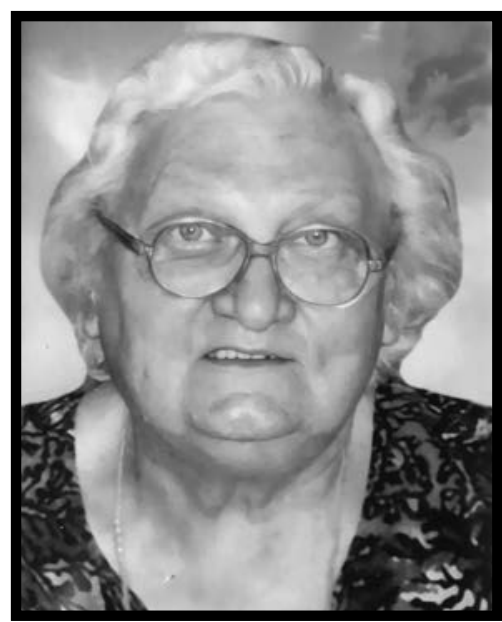

Дитинство і юність пройшли в улюбленому місті, дівчинка була дуже вдумливою і серйозною. Після тяжких військових років юна Ада горіла бажанням допомагати людям, тому в 1944 р. вступила і в 1949 р. закінчила Одеський медичний інститут за спеціальністю «Педіатрія». Молодого спеціаліста направили в Тернопільську область, де Ада Іванівна посіла посаду завідувачки районної санітарної епідеміологічної станції Золото-Потоцького районного відділу охорони здоров’я. У 1950 р. продовжила навчання в інституті удосконалення лікарів і пройшла спеціалізацію з кісткового туберкульозу в м. Києві, а після закінчення прибула до м. Одеси і працювала лікаремортопедом в обласній клінічній лікарні.

На молодого перспективного фахівця звернули увагу і запросили на кафедру госпітальної хірургії Одеського медичного інституту в 1952 р., а через 1 рік Ада Іванівна вже була в штаті співробітників кафедри дитячої хірургії, де під керівництвом видатного вченого М.Л. Дмитрієва в 1960 р. успішно захистила кандидатську дисертацію на тему «Внутрішньокістковий остеосинтез у дітей гетеротрансплантатом».

Ада Іванівна пройшла славетний шлях - від лікаря в районі до вченого, професіонала в дитячій хірургії. Протягом 44 років Ада Іванівна Чанг працювала в дитячій обласній лікарні, понад 8 років - у медичному центрі, до якого їі особисто запросив академік Борис Якович Резник. Усе життя вона присвятила служінню людям, стала блискучим клініцистом і діагностом.

Ада Іванівна була багатогранним хірургом, прекрасно оперувала будь-яку патологію органів грудної та черевної порожнини, опорно-рухового апарату.

Колосальним внеском Ади Іванівни в медичну науку є ії новації з кісткової пластики гомо- і гетеротрансплантатами при захворюваннях кісток у дітей, у тому числі розроблений комбінований метод кісткової пластики підготовленою спонгіозою за Дмитрієвим М.Л. пластинчастими дугоподібними гомотрансплантатами при задній фіксації хребта в дітей з тяжким сколіозом. Вона була відомим фахівцем зі сколіозу, консультувала дітей з цією патологію не тільки в Одесі, але й по всіх санаторіях півдня України.

Ада Іванівна запропонувала оригінальну щадну методику видалення гемангіом кінчика носа і пластики дефекту місцевими тканинами в дітей і багато іншого. До всього Ада Іванівна мала обгрунтований і вдумливий підхід.

Про Аду Іванівну можна багато чого розповісти: і про те, як вона любила дітей, а вони - iї; і про те, як вона щиро раділа досягненням і успіхам своїх колег та учнів; і про найголовніше - ії доброзичливість, порядність, прагнення завжди надати допомогу, уміння бути справжнім другом, здатність до самопожертви. В Ади Іванівни багато чому можна було повчитися, вона щедро роздаровувала себе людям. Усе, що робила Ада Іванівна для здоров’я людей, принесло їй любов і повагу тисяч вилікуваних пацієнтів, численних учнів, колег і студентів.

У долях багатьох Ада Іванівна зіграла значну роль: навчала не тільки медицині, хірургії, науці, але й розумінню життя та вмінню бути людиною. А.І. Чанг була і залишається вчителем, наставником, хірургом-професіоналом, другом, Людиною з великої літери.

Вічна світла пам'ять Вам, дорога Адо Іванівно! 3 любов'ю та вдячністю - дитячі хірурги Одещини 


\section{Правила подачі та оформлення статей}

Авторська стаття направляється до редакції електронною поштою у форматі MS Word. Стаття супроводжується офіційним направленням від установи, в якій була виконана робота, з візою керівництва (наукового керівника), завіреним круглою печаткою установи, експертним висновком про можливість відкритої публікації, висновком етичного комітету установи або національної комісії з біоетики. На останній сторінці статті мають бути власноручні підписи всіх авторів та інформація про відсотковий внесок у роботу кожного з авторів.

Приймаються оригінали супровідних документів з примірником рукопису, підписаного автором(ами), надіслані поштою, або скановані копії вищезазначених документів і першої (титульної) сторінки статті з візою керівництва, печаткою установи і підписами всіх авторів у форматі Adobe Acrobat ${ }^{*}$.pdf), надіслані на електронну адресу редакції.

Статті приймаються українською, російською або англійською мовами.

Структура матеріалу: вступ (стан проблеми за даними літератури не більше ніж 5-7-річної давності); мета, завдання, матеріали та методи; результати дослідження та їх обговорення (висвітлення статистично опрацьованих результатів дослідження); висновки; перспективи подальших досліджень у даному напрямку; список літератури (два варіанти); реферати українською, російською та англійською мовами.

Реферат $є$ незалежним від статті джерелом інформації, коротким і послідовним викладенням матеріалу публікації за основними розділами і має бути зрозумілим без самої публікації. Його обсяг не повинен перевищувати 200-250 слів. Обов'язково подаються ключові слова (від 3 до 8 слів) у порядку значущості, що сприятиме індексуванню статті в інформаційно-пошукових системах.

Реферат до оригінальної статті повинен мати структуру, що повторює структуру статті: мета дослідження; матеріали і методи; результати; висновки; ключові слова. Усі розділи у рефераті мають бути виділені в тексті жирним шрифтом.

Для інших статей (огляд, лекція, клінічний випадок тощо) реферат повинен включати короткий виклад основної концепції статті та ключові слова.

Оформлення статті. На першій сторінці зазначаються: індекс УДК ліворуч, ініціали та прізвища авторів, назва статті, назва установ, де працюють автори та виконувалось дослідження, місто, країна.

За умови проведення досліджень із залученням будь-яких матеріалів людського походження, в розділі «Матеріали і методи» автори повинні зазначати, що дослідження проводилися відповідно до стандартів біоетики, були схвалені етичним комітетом установи або національною комісією з біоетики. Те саме стосується і досліджень за участю лабораторних тварин.

Наприклад: «Дослідження виконані відповідно до приниипів Гельсінської Декларації. Протокол дослідження ухвалений Локальним

етичним комітетом (ЛЕК) всіх зазначених у роботі установ. На проведення досліджень було отримано поінбормовану згоду

батьків дітей (або їхніх опікунів)».

«Під час проведення експериментів із лабораторними тваринами всі біоетичні норми та рекомендації були дотримані».

Кількість ілюстрацій (рисунки, схеми, діаграми, фото) має бути мінімальною. Діаграми, графіки, схеми будуються у програмах Word або Excel; фотографії повинні мати один із наступних форматів: PDF, TIFF, PSD, EPS, AI, CDR, QXD, INDD, JPG (150-600 dpi).

Таблиці та рисунки розташовують у тексті статті відразу після першого згадування. У підпису до рисунку наводять його назву, розшифровують усі умовні позначки (цифри, літери, криві тощо). Таблиці мають бути оформлені відповідно до вимог ДАК, бути компактними, пронумерованими, мати назву. Номери таблиць, їхні заголовки і цифрові дані, оброблені статистично, повинні точно відповідати наведеним у тексті статті.

Посилання на літературні джерела у тексті позначаються цифрами у квадратних дужках та відповідають нумерації у списку літератури. Статті зі списком літературних джерел у вигляді посилань на кожній сторінці або кінцевих посилань не приймаються.

Необхідно подавати два варіанти списку літератури.

Перший варіант подається відразу після тексту статті, джерела розташовуються за алфавітом (спочатку праці, опубліковані українською або російською мовами, далі - іншими мовами).

Другий варіант повністю відповідає першому, але джерела українською та російською мовами ПЕРЕКЛАДАЮТЬСЯ! на англійську мову. Цей варіант необхідний для сайту, підвищення індексу цитування та аналізу статті у міжнародних наукометричних базах даних.

Обидва варіанти оформлюються за стилем AРA (American Psychological Association style), який використовується у дисертаційних роботах.

Приклад оформлення для обох варіантів:

Автор АА, Автор ВB, Автор СС. (2005). Назва статті. Назва журналу. 10(2); 3: 49-53.

Автор АА, Автор ВB, Автор СС. (2006). Назва книги. Місто: Видавництво: 256.

У тексті статті допускаються загальноприйняті скорочення, а також авторські скорочення, які обов'язково розшифровуються у тексті при першому згадуванні та залишається незмінними по всьому тексту.

У кінці статті автори мають заявити про наявність будь-яких конкуруючих фінансових інтересів щодо написання статті. Зазначення конфлікту інтересів або його відсутності у статті є обов'язковим

Приклад: «Автори заявляють про відсутність конфлікту інтересів» або «Матеріал підготовлений за підтримки компанії...»

Стаття закінчується відомостями про усіх авторів. Зазначаються прізвище, ім'я, по батькові (повністю), вчений ступінь, вчене звання, посада в установі/установах, робоча адреса з поштовим індексом, робочий телефон і адреса електронної пошти; ідентифікатор ORCID (https://orcid.org/register). Автор, відповідальний за зв'язок із редакцією, надає свій мобільний/контактний номер телефона.

Відповідальність за достовірність та оригінальність наданих матеріалів (фактів, цитат, прізвищ, імен, результатів досліджень тощо) несуть автори.

Редакція забезпечує рецензування статей, виконує спеціальне та літературне редагування, залишає за собою право скорочувати обсяг статей. Відмова авторам у публікації статті може здійснюватись без пояснення причин и не вважається негативним висновком щодо наукової та практичної значущості роботи.

Статті, оформлені без дотримання правил, не розглядаються і не повертаються авторам.

Редколегія 
ГРУПА КОМПАНІЙ «МедЕксперт»

медичні видання, конференції і семінари, маркетингові дослідження

med-expert.com.ua
Група компаній

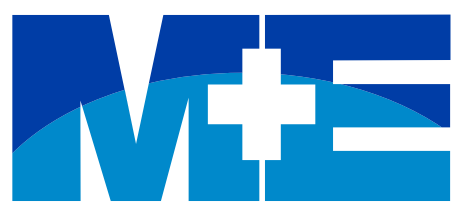

МедЕксперт
Контакти редакції

Відповідальний редактор:

Шейко Ірина

Олександрівна

+3 044 498-08-80

+3 097 110-34-20

pediatr@med-expert.com.ua

\section{ЗАПРОШУЄМО АВТОРІВ НАУКОВИХ СТАТЕЙ ДО СПІВПРАЦІ}

\section{ПУБЛІКАЦІЯ БЕЗКОШТОВНА}

Видавництво ТОВ «Група компаній МедЕксперт» випускає журнали для лікарів різних спеціальностей. Ми створюємо видання європейського зразка з інноваційним для України підходом до формування наповнення кожного випуску і висвітлення профільної тематики. Нашими експертами є не лише визнані українські вчені, але й провідні фахівці країн Балтії, Польщі, Великої Британії, Молдови, Франції, Італії, Туреччини, Ізраїлю, Китаю та інших. Усі наші журнали видаються великими накладами, доступні для читачів і мають авторитет у фаховому середовищі. Кожен з них надійно закріпив за собою позиції кращого у спеціалізованих рейтингах.

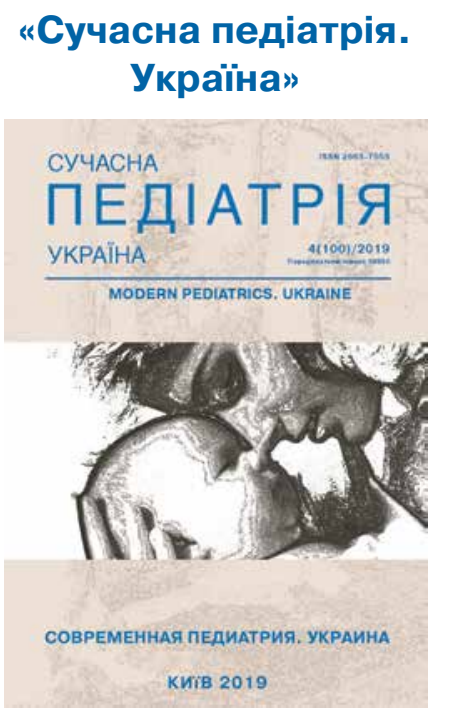

Журнал публікує результати наукових досліджень щодо методів діагностики та лікування дитячих хвороб з метою підвищення якості надання допомоги дітям в Україні.
«Український журнал

Перинатологія і педіатрія”

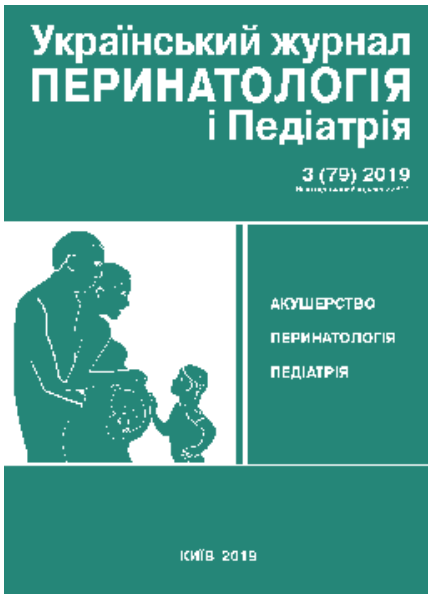

Єдине в Україні видання, яке публікує результати сучасних досліджень з проблем акушерства та розвитку дитини від зачаття до підліткового віку.
«Хірургія дитячого віку. Україна»

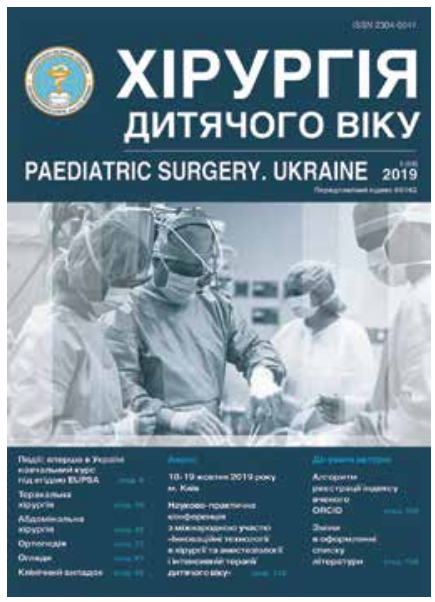

На сторінках видання публікуються результати оригінальних досліджень, унікальні та складні клінічні випадки, висвітлюються нові підходи до діагностики та лікування різних хірургічних захворювань.

Всі журнали включені у категорію «Б» Переліку наукових фахових видань України, у яких можуть публікуватися результати дисертаційних робіт на здобуття наукових ступенів доктора і кандидата наук

Визнанням авторитетності наших журналів $є$ те, що всі вони входять у міжнародні наукометричні бази. Статтям присвоюється цифровий ідентифікатор об'єкта DOI. 


\section{IV МІЖНАРОДНИЙ КОНГРЕС}

\section{Antibiotic resistance STOP!}

Стійкість до антибіотиків зростає до загрозливо високих рівнів у всьому світі. Нові механізми.стійкості з'являються і поширюються всюди, створюючи перешкоди для лікування розповсюджених інфекційних захворювань

- World Health Organization

\section{ANTIBIOTIC RESISTANCE}

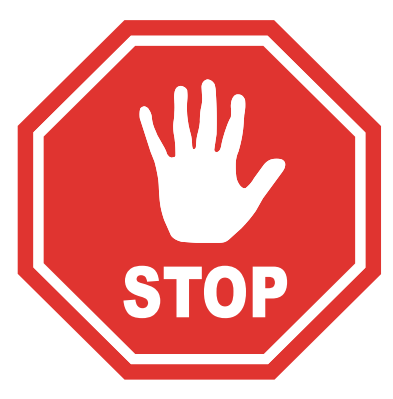

Розвиток нових антибіотиків має надзвичайне значення, оскільки еволюція мікробів продовжуватиметься безперервно, а резистентність долікарських засобів зростає.

Проблема антибіотикорезистентності стала глобальним викликом сьогодення. Головною його причиною вважають нераціональне застосування антибактеріальної терапії.

Тож під час Всесвітнього тижня поінформованості про антибіотики, в Українї традиційно буде проведено

IV міжнародний конгрес «Antibiotic resistance STOP!»,

який об'єднає провідних спеціалістів медичної галузі для розробки стратегії контролю розвитку антибіотикорезистентності

\section{antibiotic-congress.com}

